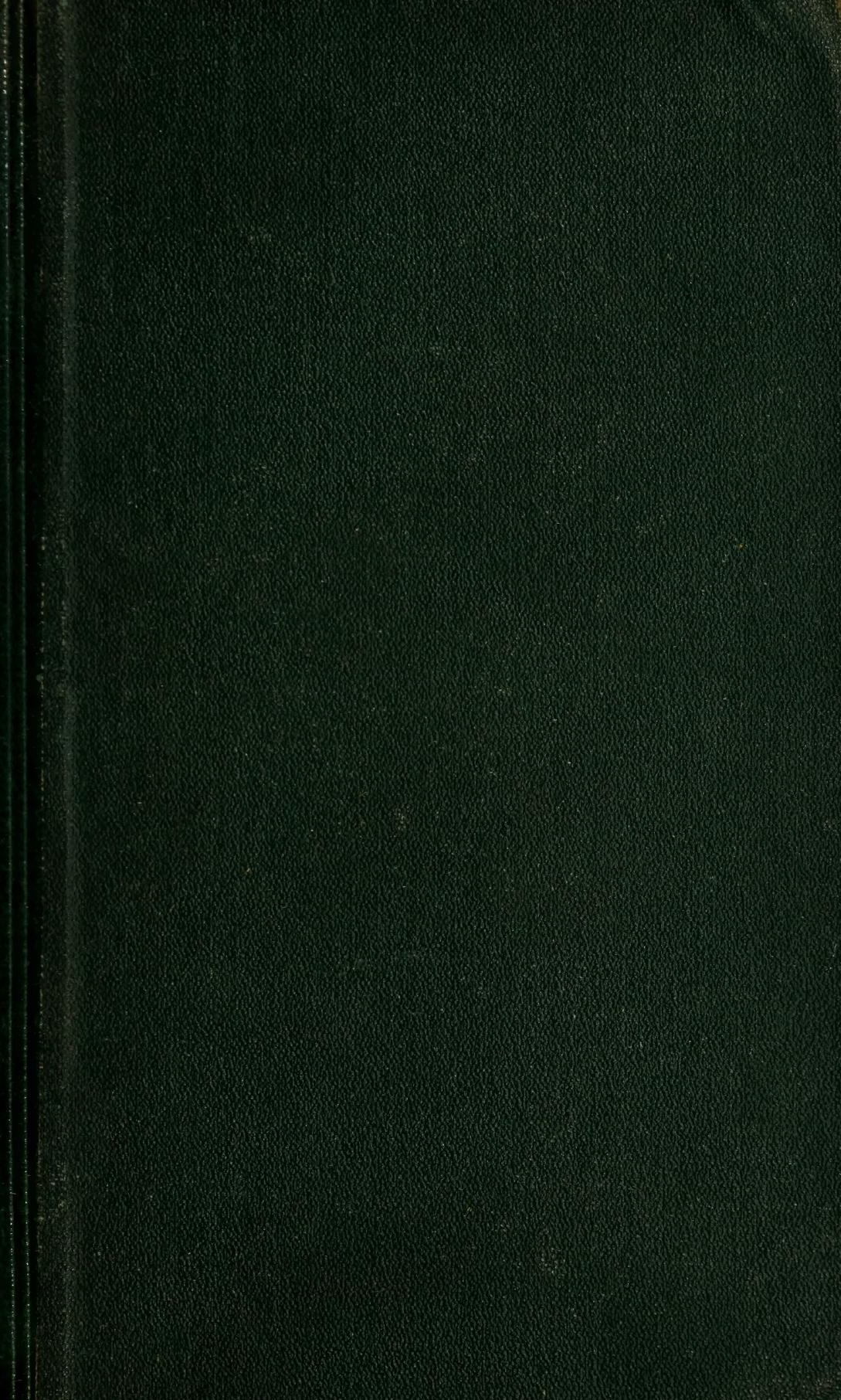




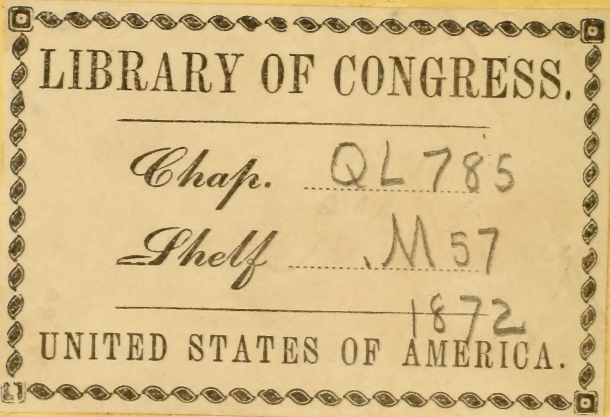





THE

\section{INTELLIGENCE OF ANIMALS}




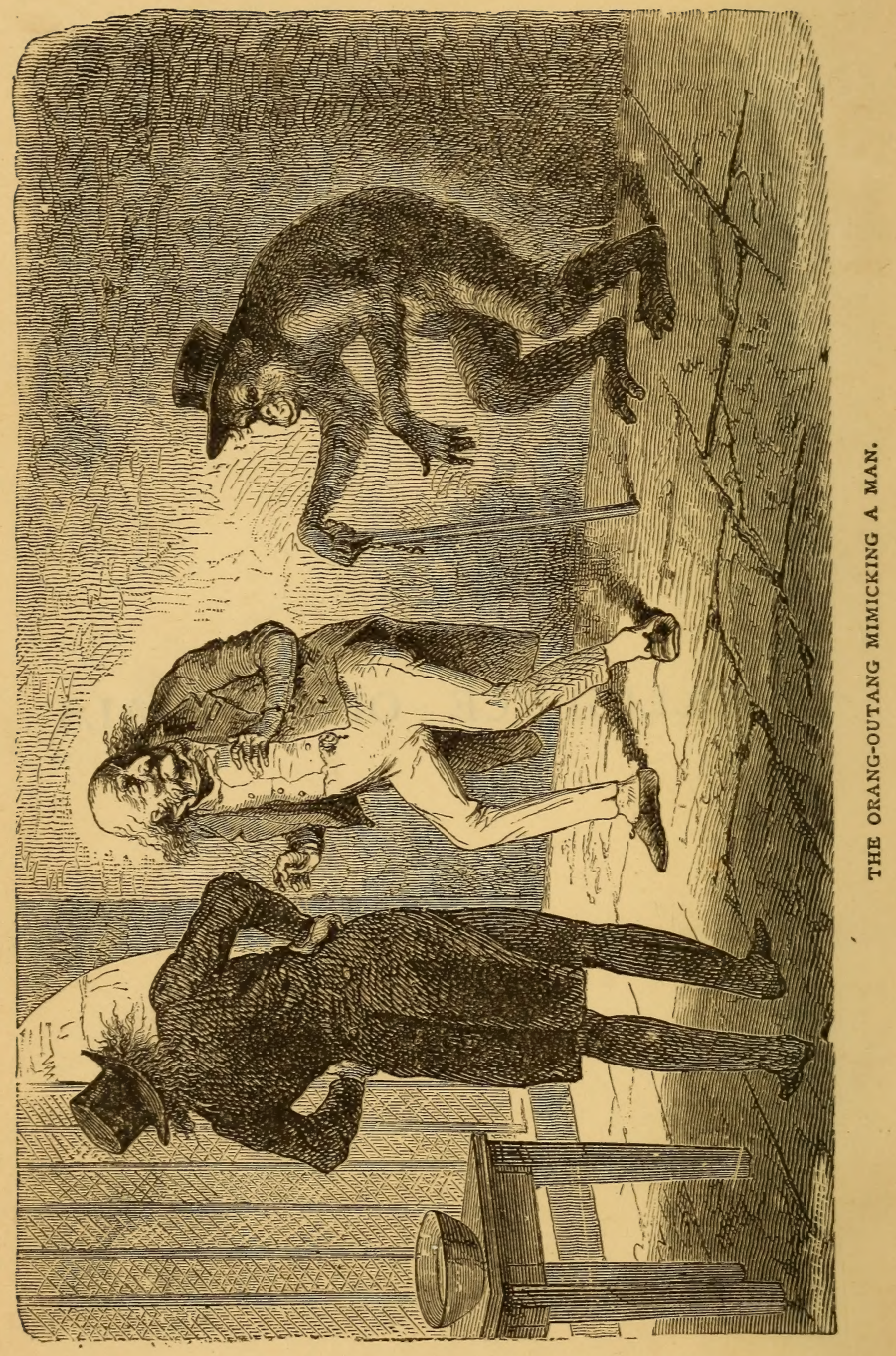


THE

\section{Intelligence of Animals, \\ WITH}

\section{ILLUSTRATIVE ANECDOTES.}

FROM THE FRENCH OF ERNEST MENAULT.

Qulith वृllnstration:

CHARLES SCRIBNER \& CO.y

654 B ROADW A .

1872 .

Monograph. 


$$
\begin{gathered}
Q L 785 \\
M 59 \\
1872
\end{gathered}
$$




\section{CONTENTS.}

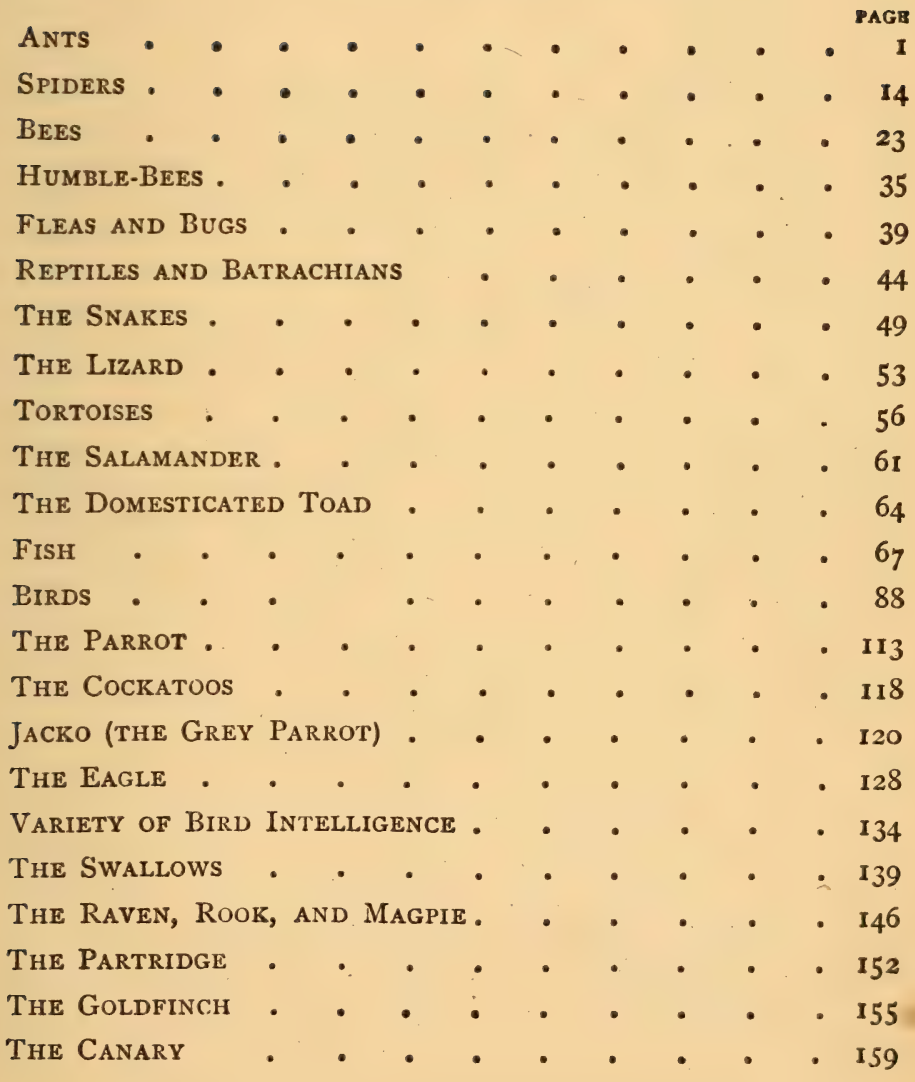


The Slandered Birds.

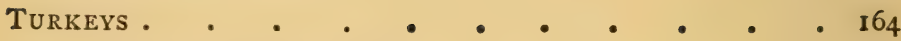

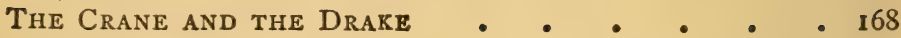

The Mammalia • • • • • • • • • 172

Cetacea . . . . . . . . . . . 182

The Marsupialia • • • • • • • • • 190

The Einentata $\bullet$ • $•$ •

The Rodentia • • . . • • . • . 202

RAts • • • • • • • • • • • 206

HARES AND RABBITS $\bullet$. . • . • • . 220

The Beaver . • • • . • • • • . 224

The Ruminants • • • • • • • • . 229

The Camel-The llama . . . . • . . 23I

OXEN • • • • • • • • • • . 233

The Stag . • . . . . . . . 239

Sheep, Goats, and Antelopes . . . . . . 245

Pachydermata $•$ • • . . • • 253

The Elephant • • • • • • • • . 255

The Horse • • • . • • • • • . 272

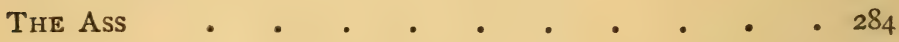

Swine • • • • • • • • • • • • 292

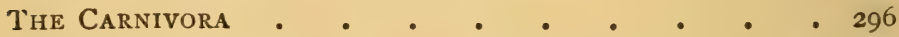

The Cat . . • • • . • • • . 298

The Wolf • . . . . . . . • . 303

The Fox . . . . . . . • • • 310

The Dog • • • • • • • • • • 317

QUAdRUMANa . • • • • • • • • • 353

The Orang-Outang • • • • • • • 355

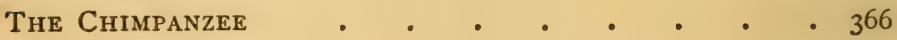




\section{LIST OF ILLUSTRATIONS.}

I. The Orang Outang Mimicking a Man.

PAGI

2. Ants, winged and wingless (workers).

3. The Ant bending a Corn-leaf.

4. The Ants with the Cockchafer's Wing.

5. The Ant carrying the Beetle's Leg. .

- Frontispiece.

6. Web Lines spanning a Stream.

7. The American Geometrical Spider and Web.

8. The Honey-Bee.

9. Death's-Head Moth attacking the Hives. . . . 28

10. Trained Fleas at Work and at Drill. . . . . 40

II. Sagacious Bug dropping from the Ceiling. •.$\quad$. 42

12. Snakes in Leading-strings. $\quad$ • $\quad$ • $\quad$ • 49

I3. Snake swimming after its Mistress. . . . • 5 I

14. Tortoise under a Wagon-wheel. • . . • 56

15. The Stickleback and its Nest. • . • • • • 78

16. Bandaging a Pike's Fractured Skull. • . . . . 83

17. The Carrier Pigeon flying Straight for Home. . . • 94

18. The Goldfinch giving notice of his Master's Arrival. 96

19. The Ostrich burying her Eggs in the Sand. . . . I00

20. The Magpie defending her Nest. $\quad$ • . . 102

2I. 'The Bird detaching a piece of the Mortar. . . . 104

22. The Cockatoo. . . . . . . . . : II8

23. The Eagle seeking his Prey. • • . . • 129

24. A Lesson for Bad Mothers. . . . . . . I4I

25. Combination among the Swallows. . . . . 142

26. The Raven fights for the Wine. • . . . . 147

27. The Crisis.

28. Love in a Cage. - . . . . . . . . . 156 
29. Goose Attachment. • • . . • . . . I60

30. A Goose Acting as Guide. . . . . . . 162

31. The Drake leading the Lady to the Rescue. • . . 169

32. The Bear tending her Young. . . , . . . 177

33. Rats following an Army. • • • • . • • 207

34. Rats attacking the Spirit Casks. • . . . . $21 \mathrm{I}$

35. The Hare running in a Straight Line. The Rabbit Doubling

Back. • • • • • • • • • • $22 \mathrm{I}$

36. Beaver building a Wall. • . . • • • . 226

37. The Camel about to be Loaded. . . . • . 23I

38. The two Rivals. • . • • . • • • • 235

39. Stag endeavoring to deceive the Hounds. • • • . 243

40. The Elephant protecting a Dog. • • • • . 264

41. The Elephant acting as a Nurse. . . . . . 265

42. The Elephant rescuing a Soldier. • . . . . 267

43. The Elephant becomes a Courtier. • • • • . 269

44. Fidelity of a troop of Bavarian Horses. • • • . 279

45. A Musical Connoisseur. - . • . • • . 287

46. Wolves attacking a Flock, . . . . . . 305

47. A Fox trying the Ice. $\quad$ • . • • • 315

48. The Shoeblack's Dog. • • • • • . 337

49. The Dog at the Convent Door. - . . . . 338

50. Vaillant Rescuing the Blind Dog. . • . . 342

51. Moffino's Return from Russia. . . . . . . 346

52. The Fishing Dog. • • . • . • • . 348

53. The Dogs and their Dead Master. . . . . . 351

54. Chimpanzee at Table. $\quad . \quad$. $\quad . \quad \cdot \quad \cdot 367$ 


\section{PREFACE.}

'THE marvels of animal intelligence claim now, more than ever, the attention of observers. Without admitting, like some people, that we come from a quadruped; without approving the beast worship of the Egyptians; we believe that most animals which crawl or walk on the earth, or fly in the air, form communities like ourselves. We believe that the lower animals possess, in a certain degree, the faculties of man, and that our inferior brothers, as Francis of Assisi calls them, preceded us on the earth. We agree with Montaigne, Réaumur, La Fontaine, George Leroy, and Frederick Cuvier, in the intelligence of animals ; we admit, with Cabanis, that there exists an intimate connection between the organisation and the intellectual faculties; and, with Gall, that the intelligence principally operates through the brain. We do not believe that the habits, industry, and art of animals remain immutable. Has it not been observed, times out of number, that old animals are more cunning than young ones? The little bird which builds its nest for the first time fashions it and places it 
badly. By degrees it perfects its work, so that the nest leaves nothing to be desired-the artist has attained the ideal. It is thus that, by the repeated exercise of the memory, combined with reflection, the animal improves itself. The bird of prey teaches its little ones to fly in the air, to balance themselves there, to keep themselves immovable, to slacken or quicken their flight, to calculate distances, and to pounce down upon the victim. Look, also, at the swallows, when about to depart. The youngest, who have not yet undertaken the voyage, prepare themselves several days before by a multiplicity of evolutions. After several repetitions, their parts being well known, and the instruction perfect, the signal is given, the large army flies away, well prepared by discipline for the journey.

The wolf, so greedy of flesh, does not succeed in its carnivorous trade except after a long apprenticeship

The intellectual manifestations in animals are connected with their organisation and their nervous system; this is what we shall show, in studying the principal families of animals.

It is known that the animal kingdom may be divided into five great orders :-

r. Vertebrated.

2. Articulated or annelidæ.

3. Mollusks.

4. Radiated or zoophytes.

5. Protozoa. 
Protozoa, a name taken from the Greek, signifies first animal, and presents the most simple organisation. Formed of separate cells, we do not recognise in them any distinct organ.

We can understand that, in such elementary beings, it is difficult to find the least trace of intelligence.

The Radiated animals owe their name to the disposition of their organs round a nervous centre, and are also called zoophytes, because they have something of the form and organisation of plants. Their nervous system is little developed; and it is difficult to note intelligence in these beings, that have neither head nor heart, neither arms nor legs ; in which animal life is scarcely separated from matter; created only to eat. The sole organ they possess is a stomach, an alimentary bag, sometimes divided into many pockets or cavities, and having only one opening to receive the food.

As we go higher in the series of beings, we see near this stomach a brain, nerves, and delicate senses fitted for all functions; so that the more perfect beings do not only live to eat, but also to feel, act, and exercise, more or less, their nervous energy.

Among the Radiated we may consider the walk of the sea-star as an act of intelligence. This animal disposes its rays in such a manner that they suit the form of the object on which it crawls, whether sand, large stones, or small pebbles. The "star" climbs thus on the perpendicular 
rocks, attaching itself firmly. This sea-star discerns per fectly, by the aid of touch, on what ground it finds itself, and the obstacles to be surmounted, and acts in the most intelligent manner according to circumstances.

Thus, in the class of Radiated animals, we meet with the first elements of a nervous system, and the first manifestations of intelligence.

The Mollusks are known by their soft body, without an interior skeleton. They possess a nervous system but little developed, and usually composed of two parts; one over the food-passage, the other beneath, and joined by a membrane, which surrounds the gullet with a real nervous band. Some small glands are disposed round the principal organs, and attached to the brain by threads of communication. Some mollusks are gifted with organs of motion, of vision, and of muscular contraction. Those which are covered with a shell, like the oysters, are called testaceous mollusks.

If we take the most perfect type, the cephalopods-those that have the brain protected by a little cartilage that may be compared to a skull, and the most complete circulatory apparatus, we recognise in them signs of intelligence. Nor are the gasteropods wanting in similar faculties, as may be seen in the snails, which find out every night the fruits and plants suitable for food, although each morning they go far away to make their siesta till the evening.

But it is in the class of insects, and especially of hymenopterous insects, that we find proofs of intelligence. 
So we shall not seriously begin our study till we come to these little beings. Their body is symmetrical, composed, in the greater number, of a succession of joints or rings, to hold the intestines. As their forms are best developed, so their nervous system is equally energetic. They possess a brain, nervous chords round the gullet, and a series of glands below the intestinal canal. The animal and intellectual life ought to be the more elevated, as it abounds in nervous and sensitive elements. "We note in these animals," says Réaumur, "as much as in any of the others, proceedings which lead us to believe in their having a certain degree of intelligence." Other naturalists have pretended that, in this respect, these insects surpass all other animals.

The forms of life in insects agree with the one great plan of organisation, and though very different from animals with a more complex system, do not differ from the general type of organised beings. The forces which organise a mite's body are not smaller, according to Réaumur, than those required by an elephant's structure. We ought not to have needed philosophy to teach us that great and small are only words of comparison with respect to ourselves. The structure of microscopic insects is often more admirable than that in animated masses of colossal size. The production of insects seems then to require as many energies and as high a mechanism as that of the larger animals. In some respects insects have the superiority. In all the 
large animals there are only two eyes. The common fly has eight thousand; and some have counted twenty-five thousand in certain butterflies. Each of these organs presents, though in microscopic proportions, the greater part of the divisions which are found in the composition of our eye. Closely crowded together, these eyes make up for immovability by quantity. Their mass is such, that in certain flies they occupy nearly the whole of the head, and even equal in weight one-fourth of the body. The shape and colour of these eyes are not less various or less remarkable, corresponding, undoubtedly, with modifications in the sense of seeing. Insects which seek their food during the night have eyes formed to receive the few rays of light which meet them. In the carnivorous insects they are larger. Certain aquatic species show sometimes several pairs of eyes. Some are directed upwards, others down, so that, while swimming on the water, the animal sees the fish which threatens him, or the bird which is ready to pounce upon him. Others have three little eyes, arranged in the form of a triangle, on their heads, making three powerful microscopes. We find these eyes in insects inhabiting dimly-lighted places, or living in nests. They must be able to perceive the smallest objects when exceedingly near.

Insects possess a very delicate sense of smell. The slightest odours strike them at the greatest distances. Distant honey attracts bees. We see them going far to 
seek the flowers which inclose it. The fly smells from afar the meat fitted to yield it food.

Each insect knows perfectly how to recognise what agrees with it. Those who eat jalap, or other drugs, take the nutritive part, showing great care not to touch that which is purging.

Cuvier and Duméril place the seat of smelling in the small openings, in the shape of a button-hole, called stigmata, by which the air is introduced into the breathing tubes. There is here, says Mr. Pouchet, a manifest analogy to the situation of the nose, which is placed, in the large animals, at the entrance of the breathing apparatus. De Blainville thought that this sense is in the antennæ, little movable horns found in front of the head. Indeed, these, like the nostrils of the large animals, contain the first pair of nerves which come from the brain. Some experiments made by Dugès tend to demonstrate that it is really these antennæ which represent the organ of smelling. After cutting them off butterflies and flies, these insects could no longer go in search of their food.

We must acknowledge that the insect's ear is not anatomically known, but we ought not to doubt its existence, for many insects produce noises by means of which they call and reply to each other.

It appears that touch is seated in the antennæ. It suffices to see an insect go out of his hole and explore its environs with his antennæ to be convinced of this fact. It 
is by the help of these organs that insects seem to measure bodies, try to lift them, and ascertain if they are too heavy, too hot, or too cold.

We have insisted on the wonderfui organisation of insects in order to suggest their intellectual aptitudes. Camper admitted that the more animals had the facial angle acute, the lower was their intelligence. Wite has rendered this principle obvious by figuring the heads of a long series of the vertebrated, from man to the crane, in which the extreme lengthening of the face corresponds with its intellectual inferiority. Mr. Pouchet thinks that we might execute a similar work for insects. At the beginning of the list would be found, according to this naturalist, the carnivorous beetles; at the bottom of the scale the timid weevils, with slender, elongated mouths, which would correspond perfectly with the cranes. After many observations, we conclude that the most intelligent insects are the hymenoptera, bees and ants; and think that if any one compares the size of an ant's head with its body, Camper's law would be confirmed. The insect, the ant, above all, is as well organised in the brain as the greater part of animals. We shall, then, commence sur study with the ants. 


\section{THE}

\section{INTELLIGENCE OF ANIMALS.}

\section{ANTS.}

THEIR ACTIVITY, INDUSTRY, HABITS, LANGUAGE, AND GOVERNMENT.

THE intelligence of the ants has been a subject of remark for many ages. The old biographer Plutarch relates the observations made on these insects by the Greek philosopher Cleanthes, three hundred years before the Christian era. The French philosopher and essayist Montaigne describes their wonderful means of mutual communication without the aid of speech.

Their organisation is, indeed, very remarkable. The head is large; the jaw strong; the antennæ long and delicate; the feet small, and furnished with claws, by which they cling to objects; the body light, without ornament, or any means of protection. The ants, when hatched, are completely naked; but they have good nurses, who lavish on them the most assiduous care, bestow upon them the most tender caresses, expose them to the sun in warm weather, and keep them in the cells when it becomes cold. 
The ants make up for the weakness of their bodies by the swiftness of their feet, the fineness of their touch, and the number of their eyes, which inform them of approaching danger. They possess a powerful acid, which is ejected against foes, and, in some species, will even blacken or burn the trees on which these insects make their nests. They have a government, too, which is a pure democracy, and seems to realise the political

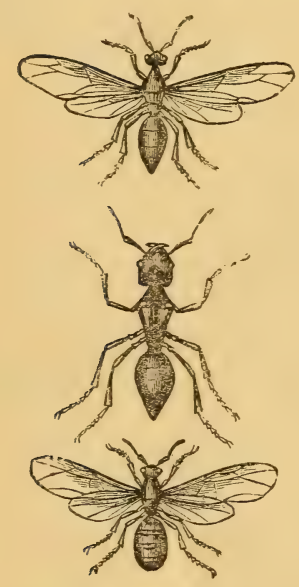

Ants, winged and wingless (workers). dreams of Plato, or those of Sir Thomas More. Of course, in this insect republic the property belongs equally to all; even the babies are claimed by the state. The whole community forms a brotherhood, and no individual is distinguished by aught save ardent love for the public good.

The females are at all times surrounded by a respectful court, are even carried in triumph when fatigued, and nourished with the richest food. But they have no influence at all in the politics of the state, and are quite content with being the mothers of a powerful community. These ladies are thus honoured while living; and Huber declares that they are even buried with an extraordinary display of ant magnificence. All governing power rests in the mass of the society.

These facts prove, surely, intelligence in the ants. We think it needless to speak of the instincts or sagacity of the female workers, which are wood-cutters, carpenters, and 
purveyors; or to reproduce the excellent description given by Huber of the ants' nests.

However, we will give some account of the ash-coloured ants, which construct their nests differently from all other species. Their work is, indeed, simple, compared with the ingenuity of the red or meadow ants; but they, at least, build like intelligent apprentices. Their hill is formed of a dome of earth, closed entirely, except at the bottom, where it is entered by a long and winding gallery, hidden in the earth at some distance from the nest.

"If they wish to raise the house higher," says Victor Rendu, "they begin by covering the top with a layer of earth drawn from the interior. In this stratum they then trace the plan of another story. First, one of the ants digs little furrows at unequal distances, but nearly of the same depth. The solid ridges of earth between the minute excavations serve as foundations for the inner walls, which form partitions for the various working chambers connected with them. The excavated earth is used for constructing the ceiling. When the cells have been formed in the trenches, the architect has only to finish the roof. One worker begins to take away the earth; she makes a furrow, which by degrees becomes a lane, on each side of which is a bank. This lane forms at last a scrt of path, leading to the gallery, at the bottom of the nest. When this is finished, another ant begins another gallery, which is also near to the apartments of the nest. The ants which thus trace the plan of a wall, apartment, gallery, or avenue, work each one by itself; and sometimes it happens, in consequence, that the different parts of the structure do not agree one with the other. One arch, for instance, is closed up; or is too low for the wall to which it should be joined; some- 
times it is only half the height it should be. Such an obstacle appears insurmountable for such a feeble insect. The ash-coloured ants are not startled at this; one ant passes, sees the error, destroys the road commenced, raises the wall on which the path should rest, and makes a new road, which this time, constructed by an experienced workman, fulfils perfectly all the conditions. Is not this an act of comparison, of judgment, and of intelligence?"

"It is when the ant commences such an enterprise," says Huber, "that we see she thinks while she works, and realises her ideas in her work. When one of these insects sees on the nest two little bits of grass, which cross one another, and which would serve for the construction of a cell, or when she sees several small sticks of angular shape, she examines all these things, and then places a little earth in each of the spaces and along the sides of the sticks with great skill, without paying any attention to the work that others may have sketched already. So much is she ruled by the idea that she has conceived, and which she carries out without distraction, that she goes, comes, and returns, until her idea is understood by the others; then all work together in common to carry out the plan which one has commenced. The first ant which conceives a plan sketches it ; the others have only to continue the work commenced. At the inspection of the first works, the insects judge which they will undertake; they know how to sketch, continue, polish, or complete their work, according to circumstances. Their teeth-like jaws serve for cutting tools, their antennæ for instruments of measurement; and their front feet are the trowels with which they mix the mortar, apply, spread, and fix it as solid cement."

Dr. Ebrard, an author of keen observation on the habits 
of the ant, was one day witness of the stratagem of a black ant, which showed the most ingenious calculation on the part of the insect. "One day," says he, "I saw on the summit of an ant-hill an entire sketch of a new story in construction. It was a series of galleries, formed by two parallel walls, half covered and intersected by numerous and unfinished cells. The upper parts of the party walls in these little rooms projected inwards about one-tenth of an inch, leaving spaces between, about seven-tenths of an inch wide, uncovered. The black ants do not fetch bits of sticks or grass, neither do they construct pillars. How did they contrive, then, to finish covering in the cells before the materials forming the arches fell by their own weight? The soil was wet, and the work in full force. It was a constant running to and fro of ants, coming from their subterraneous dwelling, and carrying particles of earth, which they adapted to the old constructions. Concentrating my attention on the largest cell, I saw that only one ant worked there; the work advanced, nevertheless. In spite of a projection inside, between the upper part of the walls there still remained a space of about half an inch to cover in. This was the time to support the earth of the roof by little pillars, beams, or the remnants of dried leaves; but the black ants never have recourse to any of these means, it is not in their nature to employ them. The solitary ant left her work for a moment, and went to a cornstalk a little distance off. She ran up and down several long and narrow leaves, then choosing the leaf nearest to her, she fetched wet earth, which she fixed at the upper extremity. She continued this operation until, under the weight of earth, the leaf inclined gently towards the spot it was necessary to cover. This inclination took place, 
unfortunately, near the top of the leaf, which seemed inclined to break off. The ant, noticing this new inconvenience, gnawed the leaf at the bottom, so that it fell down full length over the unfinished cell. This was not en ough; the position was not right. The worker arranged it properly by putting earth between the base of the plant and that of the leaf, until the leaf fell sufficiently low. The desired end obtained, she used the leaf as a buttress to

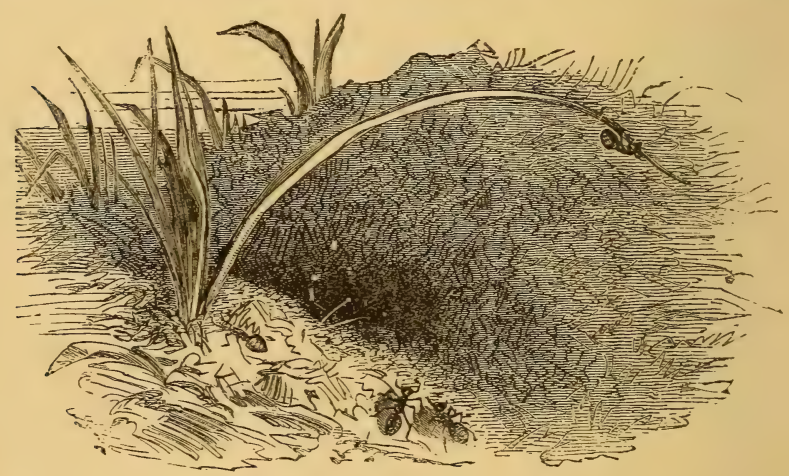

The Ant bending a corn-leaf

support the materials with which she intended to form the arch."

After these different observations, which give us incontestable proof of the intelligence of the ants, we will ask you, candid reader, to allow us to tell you what we have seen with our own eyes. It was in the latter end of May, when the cockchafers, after having devoured the leaves of the trees, began to die on the roads, and became the prey of beetles and ants. I was walking with one of my friends, a lover of natural history, when we saw some ants actively occupied round a wing of a cock- 
chafer. What were they doing? You will hear. They were pulling the wing towards a little hole, which was certainly too small to admit it. How could they manage the matter, then? They were obliged to think. The ants are never embarrassed. It is very probable, however, that they had never before encountered such an obstacle; that what they were obliged to do now was not a matter of habit. They began to direct one of the extremities of the wing towards the little gallery of their home. Three of them, judging that the thing could not go alone, went

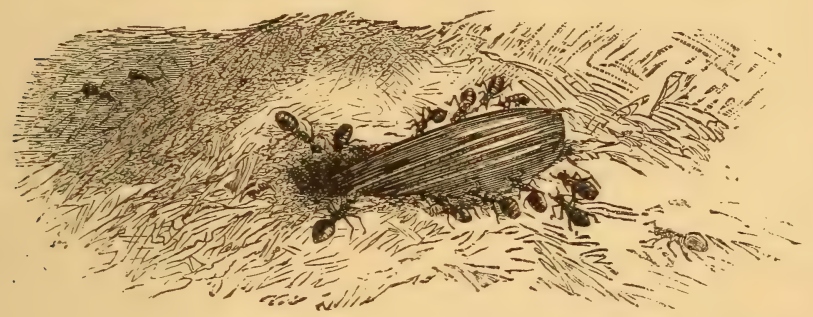

The Ants with the Cockchafer's wing.

into the hole, pulling the wing underneath, while the others pushed it from above. But, vain effort! the wing would not enter. What could they do? Must they abandon such a great prize? No; the ants are as courageous as they are intelligent. Without losing confidence in their activity and their genius, they renounced their first idea. They placed the wing against one of the partitions of the opening, and went into the nest on the other side of the wing. They no doubt thought what it would be necessary to do. They then resolved, full of activity, to enlarge the gallery. Each one descended in turn, bringing a particle of earth, which she placed at the side of the opening. They worked so 
well, that in less than half an hour the opening was half as large again. It was nearly three-tenths of an inch in diameter, and the wing was three parts pushed in. No doubt in a little time the wing will be completely in; when, lo! behold, another ant arrived, pulling, triumphantly and alone, another insect. Her sisters saw her, went to meet her, and dragged the insect towards the opening, where the wing of the cockchafer was still waiting. They slipped along the wing as if it were an inclined plane. Two or three descended, dragging the insect by the head. One minute afterwards it had disappeared. The ants, happy and proud of their success, returned to the wing of the cockchafer. They tried for some time to make it enter by force, but it was impossible. Then an ant took it in his mouth, carried it outside the hole, and his sisters began to work again. They ran up and down the particles of earth they had taken away from the partition to make the passage larger. Some of them, in a great hurry, took the wing, and pulled it again towards them. It nearly enters, when something intervenes. The bottom of the opening was, without doubt, not quite large enough. Some did all they could to pull at the top; others push to the right, others to the left, to make it enter more easily. It was, however, necessary to abandon this proceeding, or take away the obstacle. The ants took the wing out again, and removed, with renewed ardour, all that appeared to be in their way. A third time they tried to get the wing in. A new difficulty arose-a storm, which swamped the earth. I do not know if it were by chance or by calculation that the wing, which was upside down, and by this time once more over the opening, served as a shelter to the ants, who continued their work. At last, at nearly six o'clock in the evening, 
after working for three hours and a half with patience, intelligence, and great effort, the hole was large enough, and the wing went to the bottom of the nest. Will any one, after this, say that these insects are accustomed to such work, that they have executed it by instinct, without reasoning, without calculation, without reflection, and without intelligence? We must have less judgment than the ants themselves to think of them in this way.

A last example will show us how much the development of a sense can aid the intelligence. The ants, we know, are guided by their touch and by their sense of smell, which is situated principally in the antennæ. Stop the ants in their course, disperse them to right and left, and they seem to be embarrassed, not knowing what to do. They go back to the spot whence they started, sounding the earth with their antennæ; then, when they have examined the spot, they retrace their steps, recover and pursue their road. Is it not by the fineness of their smell or the delicacy of their touch that they find their direction again? An ant one day saw on the road the leg of a goldbeetle. She wished to drag it to the ant-hill, which was a difficult task, as she was alone, all the others being, doubtless, occupied at other business. The distance was not very great, it is true ; it was only half a yard that she had to go; but the road was rough, difficult, covered with stones and little lumps of earth. To tell you all the troubles this little ant encountered would be impossible. The smallest projection was to her a mountain. Sometimes she went round the stones in her way, at other times she was forced to creep over them. Nevertheless, she arrived almost at the top of one of the little hillocks, when her prey slipped from her, and rolled down again; and the poor ant, vexed but 
not discouraged, was obliged to go after it. Then, like a hound, she went here and there, seeming to sniff the air and feel the earth. After a little time she regained her prize. Just think of the patience and courage of these little insects. It was not until after two hours' work, and over many obstacles, that she arrived at the ant-hill, which was in the grass near the road. There our ant found help; many of her companions ran to her aid, and in a short time,

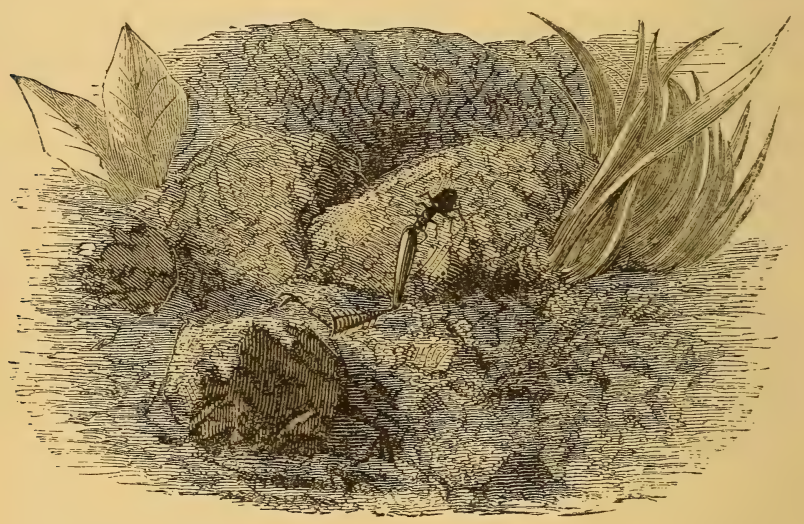

The Ant carrying the Beetle's leg,

in spite of the net-work of weeds, the leg of the gold-beetle arrived entire at the ant-hill.

It is also by the contact of the antennæ that the ant knows a friend from an enemy. By particular signs, understood by all the inhabitants of the same nest, they avoid mistakes. This is known by experiment. We give an example. Take away the ants from a hill, and put them back again after a certain time into their nest. The first feeling of these emigrants in returning to the cell is that of uneasiness. They wish to escape, but flight is not 
easy in such a noisy crowd, which goes, comes, and circulates in all parts of the ant-hill. The first workers they meet, seem to ask them for the watchword. They then touch each other's antennæ, and thus exchange signs. It is well ; they understand one another. The exiles belong to that country; their agitation ceases ; they penetrate with confidence into the native labyrinth, where they are received as sisters who have been believed lost. "Now let us," says M. Rendu, "make the reverse experiment. Introduce into the ant-hill some ants of the same species, but of another nest, and other signs than those we have mentioned will be noted. The same preliminaries are observed, but the question by means of the antennæ, instead of assuring the intruders, only increases their fright and their hurry to flee. They do not belong to that nest. The hue and cry commences; the warning is given; they are furiously chased. Woe be to them if they are caught! The furious multitudes grasp the feet, the bodies, and the antennæ of the intruders, and drag them by force to the interior of the cavern. When by chance some ants of another tribe venture to make an unlawful incursion into the nest of others, their lives are exposed to great danger. An infuriated chase commences; they are assailed on all sides by combatants, who are reinforced at each instant. If the ants know how to defend themselves courageously against strangers, in their family they show the most intelligent brotherly feeling. Who does not know that the ants feed one another? The worker is often too much occupied to fetch her own food. When she is hungry she tells one of her companions, by striking rapidly with her antennæ. The purveyor instantly approaches, and pours food into the mouth of the hungry ant. The worker 
gives thanks, caresses the friend with her antennæ, and strokes her head with the front feet. Is not this intelligence? or more, is it not family love?"

It is well known that the red ant sometimes renounces her subterranean dwelling-place to live in the trunks of old trees. She there cuts her cells as the black ant would, builds her nest several stories high, which are supported sometimes by little columns, sometimes on thin partitions.

The red ant, then, remarks M. Rendu, cultivates two distinct professions. She raises herself, if she pleases, to the difficult art of sculpture, or descends to the modest trade of a mason; she does not think she demeans herself by changing the chisel of the artist for the trowel of the workman, when necessity enforces her to do so. This necessity, in all beings, is the most lively stimulant of the intelligence. Many species of ants in America have, under the influence of that beautiful climate, acquired the art of making honey. Our ants, deprived of this faculty, have been obliged to have recourse to the grubs, which they rear, guard, and store up to supply future wants. But if we prove that the intelligence of animals and of men is specially stimulated by want, we must acknowledge that when the want is satisfied the intelligence often declines. This has been the fate of conquering nations, who fell in consequence of too great refinement and abuse of power. Certain tribes of conquering ants seem to have suffered in the same way. The great red ants, named amazons, with long legs, having a rude and soldier-like gait, attack the black ants, carrying away the young female workers, and treating them as slaves. They are obliged to nurse the larvæ, and thus aid the society of their captors, because the amazons have no plebeian ants which would form the 
working class, composed of laborious female workers, who nurse all the younger ants for the good of the republic, and do all the work of the little city. The origin of these red ants has much exercised the sagacity of learned men.

"There is, then," says Michelet, "a mystery that can scarcely be explained now; but the general history of the species, its migrations and its changes, if it could be written from the commencement, would probably make all clear. Who does not know how animals change, outwardly and inwardly, in their forms and manners, by constant removals? Some species make progress, others go back; and it is thus, says a clever author, that I should explain this slave-hunting habit of the red ants. They would not live two days unless they added others to their number. They then, rather than perish, steal the black ants, who nurse the young of their captors, it is true, but, at the same time, govern them. And this takes place not only in the city, but outside also ; the black ants decide the expeditions, or adjourn them; directing even the wars, while the red ants, far from arranging the most simple matters in time of peace, do not even seem to understand them. This is a singular triumph of intelligence." 


\section{SPIDERS.}

THE habits AND INTELligenCE OF THE MYGale.-THE SILK-SPINNING SPIDER.-CUNNING OF THE SPIDER IN CATCHING ITS PREY.

THE arachnida - named from the Greek arachne, a spider-are distinguished particularly from the articulated ${ }^{*}$ animals; nevertheless, the class is far from being a very simple one. Great differences exist in the organisation of the various orders of which it is composed. It is also impossible to explain, in general terms, what the intelligence of the arachnida resembles. But it is known that they possess a nervous system, variable in its development in the different orders, but attaining, in general, a high degree of centralisation. Some arachnida are deprived of the sense of sight ; but the greater part possess eyes, which are always simple. It is known that the extremities of the feet in the arachnida are perfectly formed for exercising the sense of touch; but nothing is known respecting the other senses. In proof that the arachnida, and especially the scorpions, are gifted with a nervous system, we may note how the least prick on the nerve ganglions causes immediate pain. The animal seems unable to control itself, and appears to have lost all consciousness of its movements. The results of the experi-

- A Latin word, signifying formed of joints. 
ments made by M. Emile Blanchard is, that feeling in all the arachnida depends exclusively on the cerebral ganglions. *

No trace of control over the movements is visible in the scorpions when these ganglions are affected; just the contrary has been found in the other articulated animals in which the nervous system has not attained the same degree of centralisation. Amongst the arachnida, the araneides, or spiders proper, may be mentioned as one of the most natural divisions, and the best characterised of the entire animal kingdom.

The species of this zoological group having become very numerous, a necessity has been felt of establishing subdivisions among the arachnida, and giving more attention to their characters, than had before been the case. This work was commenced by the celebrated entomologist Latreille, but it was soon found necessary to arrange these animals after a peculiar method, to make the specific descriptions easy. Walcknaer-a name justly honoured by entomologists, by the learned, and by geographers-found in the arrangements of the spiders' eyes, and in the nature of their web, the means of establishing secondary divisions, for the most part natural enough.

In the classification of Walcknaer, all the species of the zenus areneat formed a large group, which he called araneides, since adopted in all zoological works. Amongst this group of spiders, we will describe the mygale, $\downarrow$ whose industry and intelligence are so remarkable.

The mygale not only possesses a well-organised brain,

* A ganglion is a small roundish mass of nervous matter.

+ The Latin name for the spider.

$\ddagger$ Ancient name for a shrew-mouse; now given to a genus of large spiders, which often form their nests in the ground like mice. 
but is also gifted with certain organs of sense really wonderful, which admirably aid its industry and intelligence.

The eyes of the mygale are eight in number, forming four pairs. They are all placed on a round eminence. The usefulness of the elevation on which the eyes are situated is evident; for thus the spiders see in every direction. These eyes are not all of the same size, or the same shape. There are two in the middle, two principal ones, larger than the others, and nearly round, on the top of the eye-stalk; the others are placed on the side. In all her arrangements, nature has one end-a marvellous adaptation to manners, special habits, and the life proper to each kind of animal. Thus, the silk of the silkworms is employed by them to one use, for a defence and protection during the time they exist in the chrysalis form. But the silk of the spider, says M. Emile Blanchard, has various uses. This delicate spun substance may be employed to carpet the creature's dwelling; to make its nests inaccessible; to form the threads for trapping living prey; to serve for cables or for ladders, down which the spiders descend from great heights; to envelop the eggs, and thus defend them from the attacks of animals.

In the south of Europe, and also in the south of France, there are found spiders large in body, but very poor in silk. But these use well their small stock; not being rich enough to construct dwellings of silk, these mygales make tubes in the earth of diameters suited to the size of their bodies, and as the walls would be rough, they are adorned with hangings of the most beautiful silk, so soft that the inhabitant feels no friction when rubbing against such tapestry. This is not all ; if the retreat remained open at the surface, the mygale might easily be 
seized by some hungry animal. This spider, therefore, makes a solid door with the earth thrown out in hollowing the tube. The door is cone-shape , so as not to be pushed in by a pressure from without. On the outside it is uneven, like the soil; but inside it is carefully covered with a silky web. To a door you must necessarily have a hinge, and a lock or a bolt are often wanted; the mygale knows how to provide for all these necessities. The hinge is formed with such tough silk that it can offer a resistance surpassing belief. A semicircle of little holes, very regularly placed on the side opposite to the hinge, forms a kind of bolt. See what intelligence this spider shows when any one tries to open the door; she drives her claws into the little holes, pulls down with all her might, and thus defends her domicile. When the mygale wishes to go a-hunting, she pushes up the door, and lets it fall down again; on her return, she draws up the door with her claws, and re-enters. This is very like what is now done in many towns in the north of France, by the tenants of those lodgings where the door opens on the footpath.

Many spiders use silk for making tubes, or lurkingplaces, where they watch for their prey, or for fortresses to secure themselves from foes.

M. Blanchard has called attention to a wonderful use of silk by the water-spiders. These differ little in appearance and general structure from their more common relations. They make their homes in streams, but live much in the air. How is this managed? The spider forms a house of silk, which is a true diving-bell. This singular home is about the size of a thimble, is secured to some weed growing on the rivulet's bank, and there the spider lurks. This silk diving-bell has a white and glistening 
appearance, like silver. The inhabitant is, therefore, called argyronete, from two words, denoting " a spinner of silver."

Every one notices, and few can help admiring, the magnificent webs of the common garden-spider. The art with which they are formed is wonderful. The ancients, who examined these works, understood all their beauty, and invented the pretty fable of Arachne.* The web was so perfect, that its author seemed capable of rivalling a goddess. The spider, when about to construct the web, places a thread cross-ways between two branches, then arranges other threads beneath, which look as regular as if traced on a frame. From the horizontal thread the spider spins a vertical thread in a downward direction, and the centre of the work having been thus settled, the radiating lines are formed. Other threads are then spun, and the concentric circles constructed with a beautiful and wonderful regularity.

These threads are not all of the same kind. Those which compose the large transverse cord, the vertical cord, and the rays, are made of a silk which becomes dry the moment it comes out of the spider's body. On the contrary, those which form the circles are made of a silk which is highly elastic and glutinous-most important properties, because the threads thus completely adhere to the rays. These same spiders produce silk destined to form cocoons, in which to envelope the eggs. This silk is sometimes quite different from that of which the web is composed. While the web threads are white, this cocoon silk is of a fine golden colour. The three kinds of silk are secreted by three kinds of glands, each secreting a particular silk. The cobwebs

* Arachne, proud of her spinning, challenged Minerva to a trial of skill, and being defeated, killed herself. The pitying goddess turned the body of poor Arachne into a spider. 
of our garden-spiders give an incomplete idea of some of the threads spun by other species of the same genus. In the hottest countries of the world-in Madagascar, in the Isle of Bourbon, in the Mauritius, in India, and in the greater portion of Polynesia - there are spiders which construct webs of gigantic dimensions. They throw their filmy lines across streams, fastening them to the trees on each side. Travellers say that where these spiders are nume-

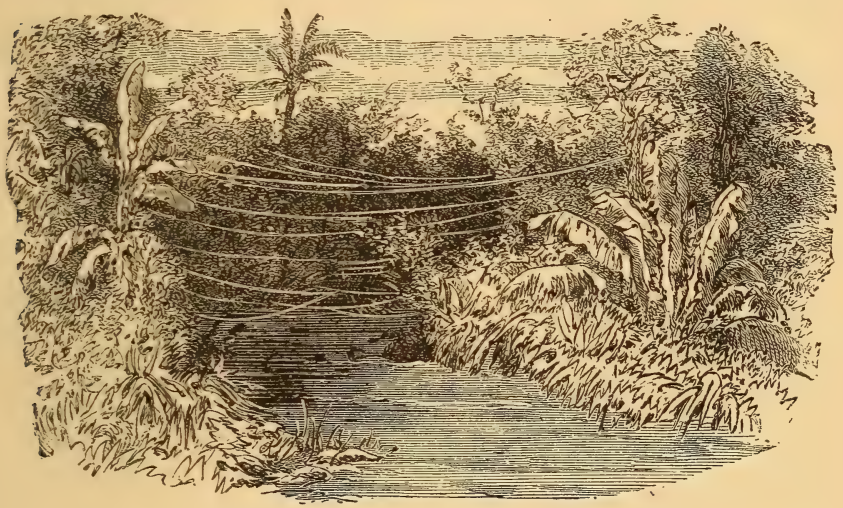

Web Lines spanning a Stream.

rous, their webs, thus thrown across rivers, produce a most striking effect in the landscape. Explorers of Madagascar, or the Isle of Bourbon, have observed a species which constructs its webs somewhat like those of the garden-spider; but there was one important peculiarity: there was in the centre a thick silvery cord or thread, twisted so as to present a series of zigzag folds. The fact having been stated, nobody could doubt the peculiar use of this thick thread. A few years later a young naturalist, Dr. Vinson, attached to the Madagascar mission, made some interesting observations 
on these webs. He often passed whole hours in observing the spider, whose mode of construction was so singular, asking himself what could be the use of this large cord, a real cable compared to the other threads? Each day he repaired to some of these webs to study them. One day some flies came and threw themselves on the threads; quickly the spider flung itself on its prey, throwing out some of the light threads, and enveloping the flies. The cable did not move. The observer broke it three or four different times; the spider, each time, made a new cable. One day a large grasshopper precipitated himself into the middle of this net. The light threads would not have been strong enough to keep such a victim. Mark, now, a proof of intelligence. As soon as possible the spider threw himself on his great cable, and rolled round the grasshopper with the greatest rapidity. That no doubt might remain, our observer returned on the following days to the same place, being determined to make experiments. He took care to furnish himself with large insects; and, throwing them into the spider's web, the same manœuvre was constantly repeated. The use of the thread was now discovered: to hold strong insects.

Many have thought, for a long time, of utilising the web of the spider; but it is difficult to obtain a sufficient quantity. The oruinary thread is ninety times thinner than that of the silkworm, and, therefore, it is necessary to have $\mathrm{I}, 800$ spiders' threads, according to Reaumur, to make a serviceable tissue. This circumstance prevents the industrial use, to any considerable value, of the silk of spiders. However, M. Lebon, president of the parliament of Montpellier, in I 709, made some stockings and gloves, of a pretty grey colour, for Louis XIV., from this silk. M. d'Orbigny made, 
from the threads of a species of American spider, a pair of drawers, which lasted a long time. Travellers tell us that, in equatorial countries, spiders' webs are seen which have so much strength that they catch the humming-birds. It is even said that men break the webs with difficulty.

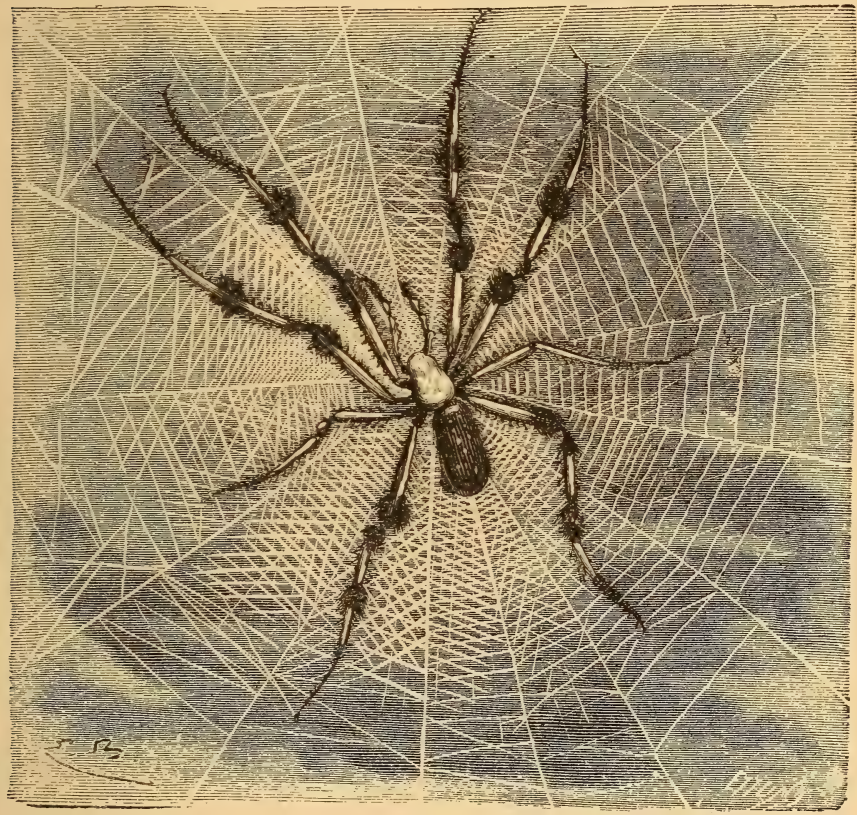

The American Geometrical Spider and Web.

But let us return to the intelligence of these creatures. It is in the means they employ for seizing their prey that spiders display all their resources. The wallspider lies down in a crack, and there, after watching a fly, springs upon it with one bound, rarely missing, so quick and sure is the jump. Another species watches on a 
tree for caterpillars near the opening of the nest, and as soon as one comes near, the spider seizes it, sucks it quickly, and then throws the body away. But that which denotes spider intelligence most, is the making of their webs. Certain spiders set up a circular network, with loose meshes for small flies; others form stronger tissues, with more solid woofs, to hold larger flies. In the first network, the threads of the woof are stronger, and twisted, radiating from the centre to the circumference; other threads, more slender, are placed circularly. By this geometrical disposition, the spider, keeping to the centre, will feel, better than anywhere else, the least movement at the circumference. This, according to Virey, is what Schmid, a learned German mathematician, proved, who published a work in which he shows that spiders, like bees, display the most transcendant geometry. But what is most wonderful is the lodging in which the spider keeps himself on the look-out. It is a real circular tunnel, with a double outlet, and a double use. The entrance is horizontal, the outlet is perpendicular. It is from the former that the hunter throws himself on his prey; the other performs the office of a secret cell.

The spider takes the greatest care never to leave at the entrance the corpses of which he has sucked the blood; this charnel-house would frighten its living food. Each time a fly has been immolated, it is dragged into a canal, and thrown into the lower opening. When we look at the floor of the den, we are surprised at the number of the spider's victims. Sometimes this hidden opening serves for a way of escape when danger is near; but this is a rare case. Its special use, its only destination, says M. Pouchet, who claims the honour of this discovery, is to receive the wreck of the spider's repast. 


\section{BEES.}

ESPECIALLY THE MASON-BEE.

THE custom of living in society is, in animals, a sign of intelligence. We have already observed this in the ants. The bees will furnish us with other proofs. These little creatures form, like man, regular and permanent societies, construct cities, establish divers orders in the state, emigrate, and even found colonies.

We are surprised when we see little animals execute such beautiful works, because we forget that the little or the large are only relative to man, who makes himself the centre of all the worlds, and the measure of all beings.

Nature surprises us, says Swammerdam, by the greatness of the works she has produced, displaying, so to

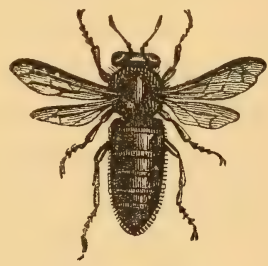

The Honey-Bee. speak, all her power in them. But she is not less incomprehensible when, in the smallest insect, she concentrates her powers in one point. We never more admire animals called perfect (those man thinks most like to himself) than when we dissect their smallest parts. They show that in a living mass all is organised, all is living; and in this sense the small is the great. Minute beauty is everywhere; it penetrates the whole of nature, and becomes an object worthy of philosophy.

After the works of Swammerdam and Moraldi, Reaumur 
apologises for writing on bees. With much more reason ought we to abstain from writing, after the magnificent discoveries of Schirach, Huber, John Hunter, and Dzierzon. We shall say nothing of the architectural wonders of these animals, so often described, nor of the cares of the workers for the little larvæ. What we shall inquire for is the intellectual manifestations in these insects. The bees come nearest the ants by their intelligence. Their government of a hive has long excited admiration. The results obtained by the bees, with instruments of extreme simplicity, astonish by their perfection. Is this skill at every instant to be called only instinct-this singular distribution of work, this admirable policy, which submits all to Law, and provides for a crowd of eventualities which could not have been foreseen?

Bees show feelings of uneasiness, hatred, and anger, direct their actions according to circumstances, know how to use stratagems against enemies stronger than themselves, and adjust their means of defence to the attack. Amongst the honey producers some families only build new nests when they cannot find any old ones; and if one is found, it is put in order. The Xylocopes* do not hollow out holes in wood till they have explored the old cavities near. They often live in the dwellings of former generations of insects of their kind, thus dispensing with all useless labour. We have other proofs of intelligence still more conclusive. We know that the honey-combs do not touch each other, a space of nearly half an inch separating them; these are the streets of the city, where two bees can pass at a time. Besides these large roads of communication other

\section{* Wood-borers.}


openings, nearly round, like little doors always open, pass through the honey-combs, to avoid the necessity of a long circuit in getting from one comb to another, or to different parts of the hive. These passages, like the combs, are not all made of the same shape, the bees accommodating themselves to places and circumstances. We find hives in which the combs all run parallel with each other, which is generally the case ; in others, the combs, which occupy a part of the hive from top to bottom, are parallel to each other, but those which fill the rest of the habitation are placed obliquely to the first ones. The bees, in beginning a second comb, often attach themselves to the opposite end to which the first comb was fixed. This second comb ought to be parallel with the first, and there should only be a certain distance between them. The insects by chance may have mistaken their measures, and the second comb is too far away from the first. The bees, in order to fill part of the vacancy, proceed with their bad arrangement, working obliquely, and giving the comb an inclination, which brings it nearer to the other. Is this mere blind mechanism? It must indeed be greater stupidity than that of the brutes not to see in these actions calculation, comparison, reflection, and intelligence.

Take another mark of intelligence, not less striking. In a hive a large number of cells are reserved only for provisions. The bees make these deeper than the others, they being sometimes eight-tenths of an inch in depth, with a diameter which never exceeds one-fifth of an inch. When the honey harvest is so abundant that the vessels are not sufficient to hold it, the workers abandon their usual mode. They lengthen the old cells, or give to the new larger dimensions than the ordinary ones. Their resources 
in the art of building are always equal to their wants. No one can reasonably say that these insects do what they have always done without reflection, without calculation, and without intelligence.

Will men still deny that it is intelligence which guides the working bee in deciding whether the cells which contain the larvæ are well provided with food? The worker visits first a certain number of cells at a time, not stopping till it has finished this general review. After having seen and examined all, the bee retraces its steps, enters one of the cells which does not seem sufficiently provided, and empties there the food which the larvæ require.

Many more intelligent acts could be mentioned. It is known that the mother bee starts with the first swarm thrown out by a hive in spring. While the new colony is busying itself preparing lodgings, building, plundering, working for the increase of the population, and caring for the race of its chief; the bees who stayed in the old hive form a strong guard round the royal cells, where there are some females in the larva state, some nymphs, and even some perfect though imprisoned insects. Of these not one will be kept captive beyond the time when she ought to enjoy her liberty; neither will any of them be liberated before the time. They will all go out of the cells successively, at some days' interval, according to their age. The law on this point is inflexible. The more efforts they make to liberate themselves, the more their guardians will watch them, rebuilding their cover as soon as they destroy it, and shutting up the opening each time they have taken their meal from the end of their nurse's trunk. Bees have, therefore, the power which arises from intelligence and will. 
Remember that at the moment of the swarming, the royal cells contain a number of females in the state of larvæ or nyrnphs. A great many only wait their time of deliverance to seize, in their turn, upon the government. One queen alone must reign; the first female who comes out of her prison destroys the others in their royal cells. The workers have recognised her quality as mother, and hinder her not; she therefore attacks all her rivals, one after another, and kills them with her dart. Huber was once a witness of this execution, in which the mother bee showed great intelligence. The queen, he says, fell upon the first royal cell which she saw, with eagerness. By dint of labour she succeeded in opening the end. "We saw her with her jaws tear the silk of the cocoon in which the royal larva was enclosed," but her efforts did not succeed as she wished, for she abandoned this end of the large cell, and went to work at the opposite extremity, where she succeeded in making a large opening. When she had enlarged it enough, she turned round and tried to get her body in. She made different movements in all directions, till at last she succeeded in giving her rival a sting. Then she removed from this cell, and the workers, who up to this time had been simple spectators of her work, enlarged the gap which she had made, and drew out the corpse of a queen, hardly free from her nymph's covering. During this time, the queen fell upon a large cell, and again made an opening, but she did not try to get in the extremity of her body here. This second cell did not contain, like the first, a fully de. reloped queen, it only enclosed a nymph queen.

M. Maurice Girard, who has written an excellent book on the metamorphoses of insects, mentions several examples of the strong memory of bees. They recognise 
their hive, he says, in the midst of a crowd of others; if a field is covered with flowers which they like, they return the year after to the same place, even though the culture is quite changed.

A wandering swarm had fixed itself on the beams of a roof, and had there begun to build their golden combs,

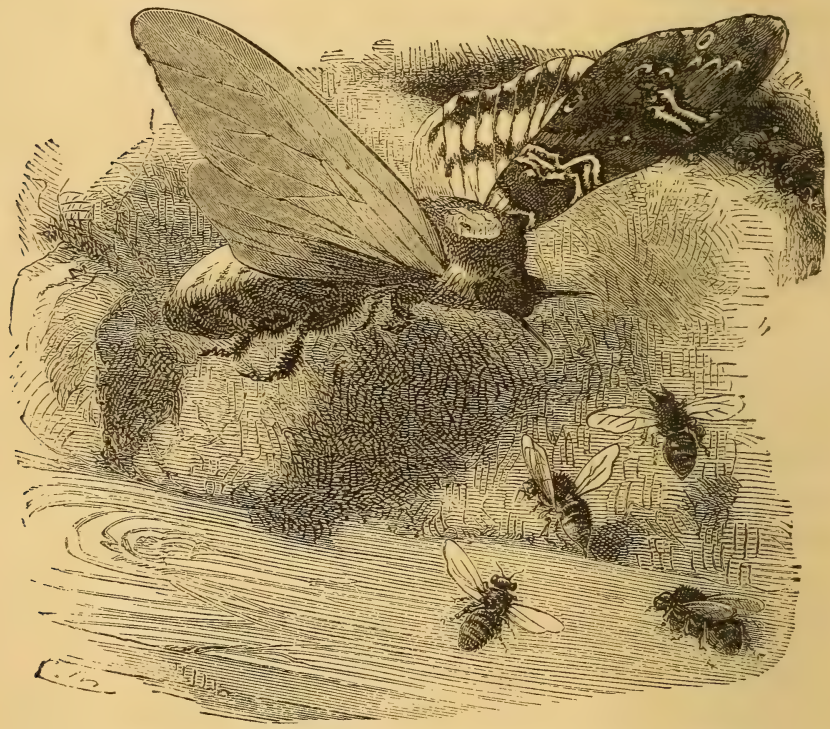

Death's Head Moth attacking the Hives.

when the householder put them into a hive. The place first chosen had pleased the bees, for during eight years all the swarms from this hive sent some explorers to the spot. The memory of the locality was not only preserved in the little nation, but transmitted to several generations of descendants.

Take one more instance of intelligence in bees. In 
1806, Huber, the elder, stated that the death's-head moths abounded, and that, greedy of honey, they entered the hives and broke all the combs with their great bodies, many times larger than that of a bee. The bees were frightened, and did not know what to do ; they had never before found such an enemy. After much reflection, they thought of employing the following device, which succeeded :-A thick bulwark of wax was raised at the entrance of all the hives in the neighbourhood, these small doors only allowing one bee to pass at a time. The greedy moths, deprived of offensive weapons, flew flutteringly against the obstacle, but could not enter. After two or three years the enemy returned in greater force, and immediately the bees shut the openings of the hives as before.

These feeble insects have solved a problem which may well excite the envy of man. We do not know by what physiological reasoning the animals were able to understand the importance of nourishment in the development of physical force, and even in the making beings fruitful which were not so before. This transformation, which our greatest doctors and our deepest observers, have not been able to accomplish, have been practised since the most ancient times by these insects. When the bees have lost their queen, and wish to obtain another, they choose some workers in the state of worms, which they nourish with a thicker, sweeter, and more stimulating food, called "royal jelly." The bees supply such a large quantity of this, that at the time when no "pap" is found in the cells of the males, or workers, the royal cells contain a great quantity of the jelly; so greatly does the bringing up of the mother bees differ from the ordinary process. Bees understand very well that for a larger amount of nourishment a greater quantity of air is required, 
otherwise digestion would be bad. It is not what one eats, but what one digests, which nourishes. They know this, and take care to enlarge the cells of the larvæ in proportion to the nourishment given. The bees do more; they ornament the cells with a new style of architecture, and enlarge them as the larva grows. When it is on the point of changing into a nymph, and the nourishment is suspended, the workers reduce the cell by shutting it up with a lid; but this contraction of the dwelling is made gradually, little by little, till the metamorphosis is complete.

It is to this special jelly, as well as to the size of the royal cells, that the larvæ of the mother bees owe their peculiarities. When the bee has lost a wife, it can replace her at will, if the hive contain some larvæ at least three days old; later, the transformation could not take place. But at this time a working larva could easily become, by means of air and food, a queen. Such is the influence of the royal jelly, that if some particles of this food fall by chance into the little cells which surround the royal ones, the working larvæ receive a portion of fecundity; but they never lay any eggs, except those of drones.

The chalicodome (one who builds with gravel), or masonbee, shows in the construction of its nest many proofs of intelligence. The works of this insect, says M. Emile Blanchard, commence in the month of May-that is to say, a short time after its birth. A female explores a wall, and chooses a place. Having fixed on this point, she goes to look for materials, and if you follow her patiently, you will see her stop on some ground covered with gravel. The insect seizes small pieces of gravel with her jaws, pours out a little saliva, joins with it some grains of earth, and thus glues earth and 
gravel together, to form the mortar that she will employ in building. The little mass being soon hardened, she flies away with her burden, and returning to the wall, applies the first layer of cement. The same operation is repeated several times ; the mass of mortar is soon sufficient for the work, and in the space of a day the first cell is constructed. But this cell remains open to a certain extent, the insect entering it several times to smooth the walls. At this time another care begins to occupy her attention-that of supplying this habitation with provisions. The mason-bee gathers honey and pollen from the flowers ; they are mixed, and the result is the sweet paste which constitutes the nourishment of all the larvæ of the aphides. The provisions being complete, and filling nearly the whole of the cell, an egg is laid. Our bee blocks up this dwelling, and directly begins to build another quite close to it, and then a third, and so on, till there are eight, ten, twelve, or even more. These cells are placed irregularly, and are not of the same number in all the nests. The cells are built, provisioned, and hermetically sealed; but the work is not yet finished. The mason insect forms a general covering, a sort of roof, for which she collects larger pieces of gravel than those used in the composition of the mortar destined for the fabrication of the cells. The exterior wall of the nest has an enormous thickness, and a prodigious hardness, which is not the least interesting fact in the construction. The larvæ will live in abundance, and be as much as possible sheltered from danger. At the time of their birth they imprison themselves in a case of varnished tissue. Their transformation into nymphs is effected, and the adult insects are formed. How will the new masons get out of their dwellings? Will they succeed in piercing this cement, 
harder than stone, and which the strokes of a hammer do not always break? It was once thought so, and so first hinted by Reaumur; but this was an error. When the lid of the nest was constructed, a cut was made in the lower edge, near a cell whose occupant is destined to go out first. It is a kind of door, only covered by some powdered earth. The instinct of the architect puzzles our reason; and does this architect only obey a blind instinct? A worker so attentive to choose both place and materials, appearing at each instant to examine the state of its work-does this bee act like a wound-up machine, performing its uniform movement? Judge by several facts in the history of our mason. Possessing exclusively instinctive faculties, she ought always to accomplish the same work-begin and finish it in the same manner. This does not take place. Cells more or less dilapidated-containing in the interior abandoned shells, or skins of nymphs, having the partitions of the cells more or less broken-remain attached to the walls. The masonbees, in their explorations, recognise these old nests, and do not fail to take possession of them. They thus understand how they can avoid much fatigue. This feeling cannot be attributed to instinct. This is not all, however. When a mason-bee thus takes possession of what we should call the ruins of a house, if we were speaking of a habitation built by men's hands, she is obliged to work in a very different way from that of the insect which builds a new nest. She must proceed to clean the interior, taking away the ruins of the shells, the skins of the larvæ and nymphs, with all the dirt. She must then repair the breaches and stop up the openings; in a word, know the situation and attend to the details of the whole work. Can it be thought that no reasoning is required in such a labour and plan. But there 
is something more striking. It sometimes happens that an idle mason-bee thinks of stealing from others; she pene. trates the nest which is being built by another individual, and finding the place suits her, strives to maintain herself there by force. Reaumur has well traced this peculiarity of the wall-bee. "These observations," he says, "teach us that the spirit of injustice is not so peculiar to man as it is thought; it is found in the smallest animals. Amongst insects, as amongst men, the goods of others will be usurped, and their work appropriated. While a fly had gone to load itself with materials to add what was wanting to her cell, M. du Hamel saw, more than once, another fly enter without ceremony into the cell, turn itself in all directions, visit it from all sides, work to refit it as if it belonged to her. The proof that she did it with a bad intention was that when the true mistress arrived laden with materials, the place was not yielded to her by the other; she was obliged to have recourse to violent means in order to preserve the possession of her goods; she was forced to join in combat with the usurper, who was ready to defend the robbery."

With a little patience anybody can easily test the facts which we have just mentioned about the mason-bees, and procure for himself a very instructive amusement. Nothing is more worthy the philosopher's meditations than these manifestations of instinct and intelligence in small animals, and of actions on their part which among men would be judged, the one praiseworthy, the others contemptible. Individuals of the same kind among the industrious bees do not all seem to have the same propensities. Some are courageous, working honestly; some are idle, and prefer not to woik, appropriating by trick or force the property 
of others. Will there long remain people ignorant enough to see in these animals only machines, and to understand nothing of the grandeur of creation? The reflections made by M. Emile Blanchard, one of the most distinguished naturalists of our time, are a noble witness in favour of the intelligence of insects. 


\section{HUMBLE-BEES.}

CO-OPERATION.-INDUSTRY AND INTELLIGENCE DEVELOPED

IN DIRECT PROPORTION TO THE NUMBER OF CITIZENS.

THERE they are, those great creatures-those fat lubbers, those snobs full of themselves, that are more noisy than industrious. Do you see them, with their eyes jutting out from their heads, their little wings giving them such airs of importance? It is certainly not by licking the walls that they have grown to such a good condition. Happy mortals! nature has gifted them with good humour: not ambitious and not wicked, they digest wonderfully. They work and feed while singing in the midst of the flowers in which they rejoice, giving themselves up to pleasures. The drones are real co-operatives; they realise easy work. Their societies are much less numerous than those of the bees. Their sociability, less developed, shows a less advanced energy, less industry, and less intelligence. The architecture of their nests is less remarkable than that of the bees and wasps. Nevertheless, they are capable of a certain intelligence. The day is come for them to choose their nests; do not think that the choice is made lightly or without reflection. From the first day of spring, we are told by M. Rendu, the females are seen flying here and there, in the meadows and on the hillocks-visiting all the holes of the field-mouse, the shrew-mouse, and retreats of the largeheaded mouse. They enter each in turn, inspecting all, and, 
finally deciding in favour of those which seem to answer their purpose best, make their abode there.

The female of the humble-bees takes special care to lay her eggs in cells of certain exact dimensions, carefully tested by repeated insertions of her body into the prepared receptacle.

The larvæ of the same cell being shut in, they live together, dine at the same table, under the same tent, feed together on the food prepared at the bottom of their cradle, and there grow. This cell loes not exceed the size of a pea when the female lays her eggs there; but as the eggs enlarge, the interior becomes too narrow, and cannot suffice for the progressive growth of the young inserts. The cell splits lengthways, and it is then that the mother displays all her intelligence. She takes pieces of wax and applies them to the sides of the opening. She goes, comes, and returns again and again with stores of wax, and repeats her work of calking, till there is no trace of a rupture left. After three or four operations of a like nature, the cell is completely shut in, being enlarged by the part added. Each time the cell bursts, by the interior pressure of the larvæ, the prison is again, in like manner, enlarged to the required dimensions, being at last about half an inch in length.

M. Emile Blanchard gives another proof of the intelligence of the humble-bees, when they wish to draw up the honey from flowers having a very deep corolla. They cannot often, on account of their size, reach down to the bottom with their trunks. This difficulty does not disconcert them: with their mandibles they cut the corolla in the lower part, and pass their trunk through the opening.

The growth of the population among these bees has this 
peculiarity - that the industry and intelligence of the city are developed according to the number of the inhabitants, and decline where the societies are reduced to a few individuals. - It is thus that the smallest communities do not cover their moss roof with wax, and do not lengthen their honey-pots, confining themselves to mere necessities. It is not the same in the more numerous societies. Frequent contact with others excites the intelligence; a sort of emulation carries more will into the work, for the common protection and care of the little ones.

Among the intelligent hymenopterous insects, we may mention the Chlorion, a solitary and digging bee. Often, says M. Emile Blanchard, have I witnessed the attack on a cockroach by a chlorion, and the intelligence displayed by the latter in bringing to its nest and getting into its narrow hole so large a body. When attacked, the cockroach knows its enemy, and is paralysed by fear. Then the chlorion flings himself on the prey, seizes it with the mandibles between the head and corslet, and pierces the abdomen with its sting. The bee then retires awhile, till the victim's struggles are over. The chlorion then drags the body to the nest, often with great labour, for the burden is really heavy. He now busies himself about getting the prey into the cell; but the opening is far too narrow to admit the feet and wings of the cockroach. The chlorion understands the situation; the difficulty does not surprise him. He cuts the feet and wings off, and then tries to push the body into the hole; but it is still too large. The bee feels that he must do something better; it goes backwards into the hole, seizes the victim with his mandibles, and tugs with all his strength. The skin of the cockroach having a certain flexibility, the body at last dis- 
appears, by passing into the hole, into which we should never have thought it could have been forced. Do such acts on the part of the chlorion only proceed from instinct? Who can think so, when observing these mancuvres, so intelligent and varying according to circumstances? 


\section{FLEAS AND BUGS.}

MOTHERLY LOVE AND INTELLIGENCE OF FLEAS.-SOLDIER FLEAS.-RIDING FLEAS.

WE will finish this study on the intelligence of insects by stating some curious facts observed in animals which, until now, have been looked upon only as torments to man. The fleas not only possess the power of making surprizing jumps, but display an almost incredible muscular force. Lémery saw a flea of middle size chained to a little silver cannon, which the insect drew after it. The cannon was above an inch long, and as thick as a small pipe, weighing twenty-four times more than the flea. The gun was supported on two wheels, and exactly like a cannon used in war. It was sometimes fired off, but the brave flea was not at all frightened by the artillery roar. His mistress, adds Lémery, kept the insect in a little velvet box, which she carried in her pocket. She fed the creature easily, by putting it every day, for a little time, on her arm, scarcely feeling the bite! Winter killed this martial flea. Mouffett says that an Englishman made a gold chain as long as his finger, with a padlock and a key; a flea being attached to this chain, drew it daily with ease. The whole mass weighed less than a grain.

Hoock relates that another English workman made an ivory carriage, with six horses ; a coachman sat on the box, with a dog between his legs; there, too, rode a postillion, 
four gentlemen were in the carriage, and two footmen behind. The whole equipage was drawn by one flea.

What a shaft horse! Are these the only works which the fleas can accomplish? No; these little beings are so intelligent, that they can be trained to all sorts of exercises.

The Baron Walckenaer, who died in 1452 , relates marvels done by clever fleas, which were shown at Paris,

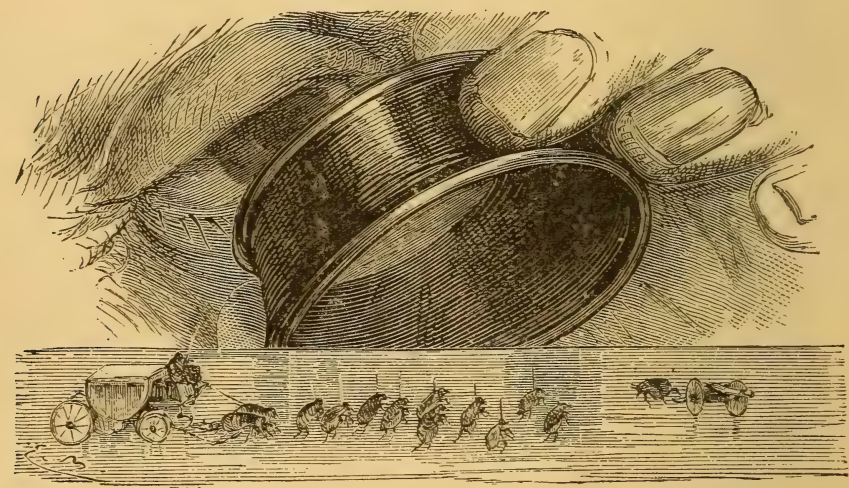

Trained Fleas at work and at drill.

in the Exchange. "I saw them," says he, "with my entomologist eyes, through several magnifying glasses. Four fleas were doing the exercise, standing on their hind feet, and armed with a pike, which was a little spar of very fine wood. Two fleas were attached to a gold travelling carriage of four wheels, with a postillion. A third flea was seated on the coachman's box, a little piece of wood representing the whip. Two other fleas drew a cannon. All these clever drillings and others were executed on polished glass. The flea-horses were attached to a gold 
chain by their hind thighs. The owners told me," added Walckenaer, "that they never took off this chain. The fleas lived thus for two years and a half. They were fed by putting them on a man's arm, which they sucked. When they would not draw the cannon or the travelling carriage, the man took a lighted piece of wood, which he held above them; they then moved, and re-commenced their exercises."

The fleas had, in $\mathrm{I}_{42} 5$, shown their rare talent in Paris, and in the provincial towns everywhere they puzzled human pride. But of what use is intelligence without a heart? It has been said that the smallest animal, the least useful in appearance, would astonish us by the patience, the courage, the spirit, and let us add sentiment and maternal tenderness.

When the fleas have laid their eggs in the dust, in the slits of the floor, on cushions where animals sleep, or in the clothes of young children, then the white larvæ, without feet, and very shaky, come out, twisting themselves like little eels. The mother flea pours into their mouths the blood with which she has filled herself, and one sees under their transparent skin the colouring of the digestive tube. Thus the drop of blood she takes from us forms the nourishment of her children.

Do not accuse this poor and tender mother any more of wickedness. She, perhaps, bites you ; it is because she is forced to do so. Nature has imposed this law on her, she cannot avoid it; she acts with all the consideration, all the management of a gastronomic insect, if you will, but she is certainly neither wicked nor a glutton. Once repulsed, the flea hastens to get away; indeed, one might almost imagine she had scruples of conscience. She leaves the 
scene of her misdeeds, but still goes a lively, jumping insect, tickling all the neighbourhood with a soft and light foot, as if to benumb and alleviate the small pain of her bite. Why does Linnæus call the flea irritating? It is the bug, the plague of night, which he ought to have so named.

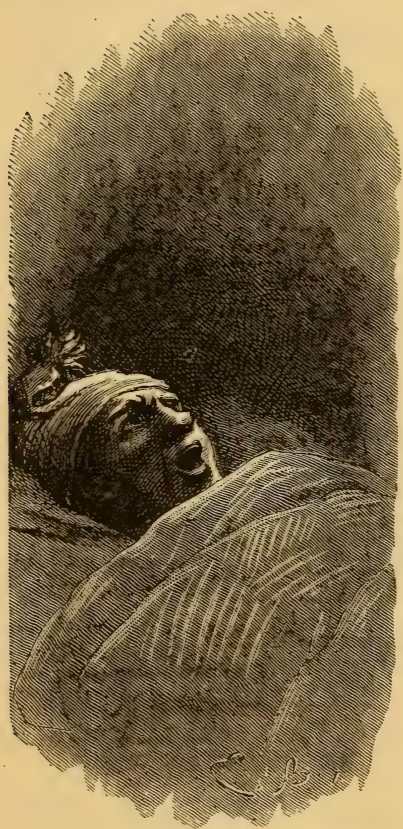

Sagacious Bug dropping from the ceiling.

That the flea teazes by its bite those among us in whom the nervous system is not duly balanced by the sanguine temperament, is true, but she does not irritate any one. This may, however, be a matter of taste. The flea does not possess the acrid fluid, or poison, of the bug. This creature does not content itself with piercing the skin and extracting the blood, but introduces a poison, secreted by herself. We have always defied mean people, and the enemies of light; now, the bug and man are the most direct and most cruel enemies of man. Their wickedness is all the more dangerous, as it is aided by an intelligence more developed.

Valmont de Bomare tells us that a curious person wishing to discover how the bug was aware of the presence of man, made the following experiment:- He laid down in a hanging bed without a top, in the middle of a room, without one piece of furniture. He then put on the floor a bug, which, 
led doubtless by the smell, hesitated some time on the means it should take to arrive at the bed. At length it took the way to the wall, ascended, gained the ceiling, got over the bed, and fell from the ceiling on to the nose of the observer. Is not this again like an act of intelligence? 


\section{REPTILES AND BATRACHIANS.*}

THE SNAKE A FRIEND OF WOMEN.-LIZARD A FRIEND OF MEN.-THE TORTOISE AND VENUS.-SALAMANDER AND FRANCIS I.-BIOGRAPHY OF A HUNTING TOAD, WHICH LIVED THIRTY-SIX YEARS.

Mythology, says Virey, in his picturesque style, formerly armed the god of the day, Apollo, with his arrows to pierce the enormous Python, $\uparrow$ which came out of the mud after the deluge. Formerly Hercules strangled the monster Achelous, $\ddagger$ in spite of his crooked windings; furious dragons guarded the garden of the Hesperides and the Golden Fleece. Men saw Perseus shaking the head of Medusa, and sowing serpents from her hair on the burning plains of Africa; the horrid Gorgons, the dreadful Furies Discord and Envy, armed with adders, frightened mankind, and petrified them with horror.

The friends of nature, adds the poet and naturalist, are to-day conquerors of so many monsters. New Cadmuses, borrowing the wand of Mercury, advance without fear into the midst of these hostile races, survey them, class them, and, covered with the shield of science, protect themselves from hurt. They see among reptiles creatures wonderful in their forms, singular in the different colours

* Greek name for frogs. † The serpent, a symbol of moral evil. $\ddagger$ The god of the river Achelous. 
which decorate them, remarkable for the strange metamorphoses of some species, and the singular habits of nearly all.

Begging Virey's pardon, we have not any sympathy for reptiles, no confidence in them. We do not like these animals, with their icy look and clammy skin, which makes you shiver when you touch them. We dislike these beings without a country, which know not whether they come from France or England; which sometimes live in the ocean, sometimes inhabit the continents; which are not fishes or quadrupeds, but pass for either, according to their interests, and cry in turn, "Long live the king;" "Long live the people." It has been said that the empire of the world belongs to the cold people; we do not believe this at all. We know that certain reptiles reach, like eagles, high positions, but not from strength of heart, courage, or intelligence; rather by meanness, and because they know how to endure injuries, to support blows, and then to run away quietly, without a spark of spirit. Their mediocrity throws no one into the shade; they are always skulking in the corners of waiting-rooms, till the door is open for them to crawl after prime ministers and kings. We dislike the reptile. $\mathrm{He}$ has neither hair nor feather. $\mathrm{He}$ deceived our first mother; and did he not cause us to lose Paradise? Can we understand how the most hideous being, and one having the least feeling of maternity, could have seduced the mother of mankind? That a superior vertebrate, an intelligent being, full of good nature and enthusiasm, should exercise such an influence, is not surprising. But a reptile! Would that it had been a bird! Among the most abject animals, the least intelligent are those which take the least care of their offspring. The majority 
of the female reptiles do not hatch therr eggs ; and some do not know their little ones. Directly they are born, the young fly from the parents as if they were enemies of their race. As to the males, real Saturns of the animal kingdom, ${ }^{*}$ they often devour their young. The crocodile shows the extreme of this insensibility. It is the most abject, the most ferocious, and the most vile of all reptiles. The dignity of animals, says Franklin, is in proportion to their care for the young. Those in whom this sentiment is the highest are the first in the series of living beings. Those in whom it is low come in the second order, and are the last of all in intelligence. So it is proved once more that nature proportions the degrees of intelligence to the strength of the affections. As reptiles have a less developed heart, cold blood, and senses in general imperfect, a great sensibility must not be expected in them.

These animals are generally timid and fearful, hiding themselves, and living alone. Even education does not awaken much intelligence in them. Certain jugglers have been able to make some species of serpents stand, by balancing themselves on their tails, while following the slow or quick movements of music. The batrachian reptiles are in a peculiar condition as concerns their organs of circulation. Undergoing metamorphoses, they first breathe after the manner of fish, and it is only later that they acquire lungs. Their heart, which has only two cavities, answers to the right side of the heart in the superior vertebrates.

We must pass in review all the functions to understand how, in the animal organisation, all works together, solidifies,

* Alluding to the fable in which Saturn kills and eats his sons. 
and strengthens itself. The more the circulation is developed, the more active is the respiration; the more pure the blood, the more the organs it supplies are invigorated; the strength is greater, the brain is more healthy and active, while the intellectual manifestations are more lively and enlarged. All the organs are in energetic combination one with the other, so that the nervous system and the brain are developed in proportion with the lungs. Even in the reptiles, those which have the larger lungs possess a more developed brain. This organ is, indeed, very small in comparison with the body, being composed of six little tubercles, which do not fill the cavity of the skull. The brain seems to play such a little part in the life of reptiles, that it can be taken away without causing the death of the animal. The experiment has been made on the tortoise, which did not, however, live above eighteen days. Reptiles eat and breathe little; their actions show very little activity, and their organs of sensation are very feebly developed. The touch is very dull, on account of the thickness and hardness of their skin. The taste seems equally little developed, the tongue being cartilaginous, and covered with a thick glutinous secretion. The smallness of their organs of smell shows the weakness of this sense. The ears alone are pretty well developed, although often wanting several of the usual parts, as the winding gallery, the cochlea, and the interior canal. The drum is usually covered with scales or muscles. Lacépède says that reptiles must have feeble sensations, and a low power of communication with other creatures, and this produces that coldness, that apathy, that confused instinct which we remark so often in many of these animals.

If, then, we observe the principles of their vital move- 
ments, we shall find a great simplicity both in the causes of motion and the effects; we shall see fewer springs of action, and the connection between the different parts less marked. The mutual communications are less perfect, and the movements slower. Is this particular organisation one among the causes of the little sensibility reptiles possess? and is this coldness of temperament increased by their life in the water? They do, however, seek the active light of the sun, they themselves having little interior heat, and rejoice in muddy places and a warm humidity. This moisture, aided by heat, serves for their development.

The reader will perhaps ask, Why all this chapter on reptiles, in which the intelligence has nothing wonderful about it? What interest can we feel in beings less sensible than others, less animated by lively passions, less active, less social, not showing art or industry, dwelling in the clefts of rocks, or in the hollows of trees; beings which never recognised a mother, and which never received nourishment, care, help, or education from her? The interest is greater than is supposed. If reptiles do not seem gifted with high faculties, if they have not the brilliant qualities, they possess the virtues of a cold temperament, calmness, attention, suspicion, and, above all, prudence; that of the serpent having become proverbial. The serpent, says Chateaubriand, associates itself naturally with religious ideas, from the influence it has had on our destinies. An object of horror or adoration, mankind has for it either an implacable hate, or kneels before it as a genius. Deceit takes its name, prudence is characterised by it; envy takes this reptile for a symbol, and eloquence is typified by the serpent wand. It arms the foreheads of the Furies, and is made the symbol of eternity. 


\section{THE SNAKES.}

ALL reptiles are not so repulsive or so spiteful as we may think; of this the green and yellow common snake is a remarkable proof. It has neither mortal poison nor fatal fang, and shows oniy agreeable movements, elegant proportions, and soft or brilliant colours. When captive, says Lacépède, it submits to a servile condition, and adopts the movements

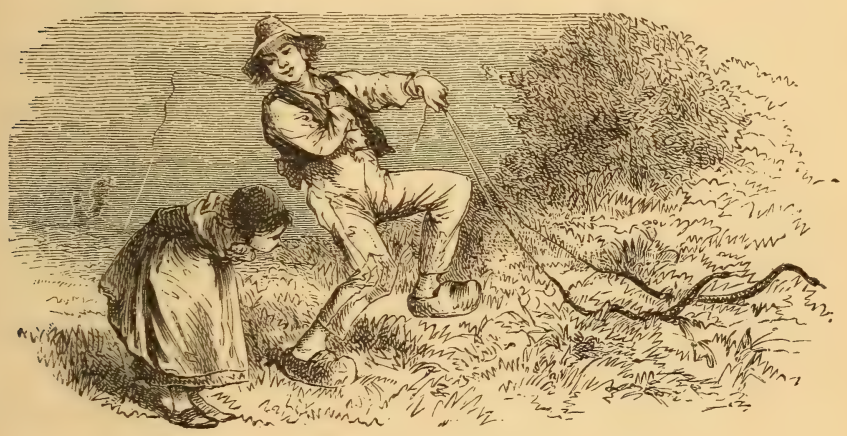

Snakes in Leading-strings.

taught. We have seen children tie two animals of this kind by their tails, and compel them to crawl side by side. They allow themselves to be twisted round the arm or neck, to be rolled into spirals, to be coiled and uncoiled, and suspended in different positions, without showing any signs of discontent. They seem even to have pleasure in thus playing with their masters. Valmont de Bomare saw 
a snake so affectionate to its mistress, who fed it, that it often glided along her arm, as if to caress her, hid itself in the folds of her dress, and rested on her bosom. The animal went to her whenever it was called, followed her constantly, even recognised her mode of laughing, and turned to her when she approached, as if to wait her orders. The same naturalist saw one day the mistress of this gentle and familiar animal throw it into the strong current of a deep tidal river, she preceding in a boat. The faithful snake, always attentive to the voice of its dear mistress, swam after the skiff which held her; but the tide coming in strongly, and the waves being contrary to the tired animal's progress, the poor reptile was at length drowned. This affection, this tenderness, this attention, so quick to recognise a person and to follow her-could it exist without something like memory and intelligence?

Some of the most deadly serpents are capabie of being trained to a degree almost incredible by those who deny intelligence to the lower animals. The venomous "spectacle snake" (Naja) of India and Africa is drilled to move and dance to the sound of music. Some are even so far disciplined as to keep under restraint the natural tendency to use their fatal fangs. It is by no means true, as many suppose, that the "serpent-charmers" always extract the poison-teeth of their dangerous pupils. The snake-tamers are undoubtedly able, by a course of patient training, to teach the fanged reptiles not only to obey each sound of the flute or the gong, but to refrain from biting under the greatest temptations. Some of these snake-teachers will twine the naja round their own necks, and place the reptile on their heads, beneath the turban, with the most perfect confidence in the creature's self-restraint. Yet the same 
snake will, in a minute after, inflict a deadly wound on a dog or a fowl broight within its reach; thus proving clearly that it had neither lost the fangs nor the disposition to use them.

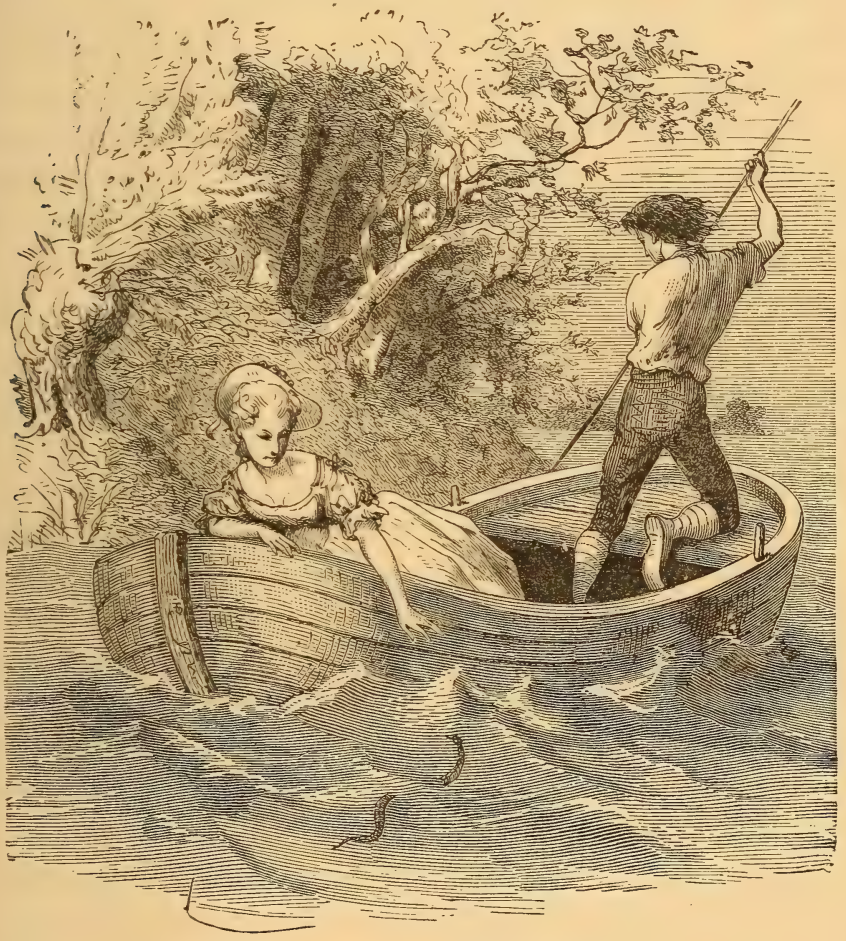

Snake swimming after its Mistress.

Now it must surely be granted that such snakes have the power of remembering and distinguishing the various musical sounds by which they regulate their movements. It is also equally clear that these deadly reptiles can be 
educated so far as to control their natural impulses. In fact, they can acquire nere habits, under tuition.

We know that "the wisdom of the serpent" has long been accepted as an axiom; and, whatever interpretation we may give to the phrase, it certainly implies the existence of what is properly called intelligence. The Buddhists of Ceylon, who believe in the divinity of the "hooded snake," may provoke our ridicule; but the European who denies the existence of any "wisdom" in the serpent, has little reason to boast of his logical power, judicious discernment, or impartial estimate of physiological facts. 


\section{THE LIZARD.}

Some lizards are so readily tamed, and become so familiar with man, that we can scarcely refuse to believe in their intelligence. The beautiful green lizard (Lacerta viridis) will take food from the hands of its owner, and even lap water from the hollow of its keeper's hand. Our prettiest British species is a small greenish-brown reptile (Lacerta vivipara), speckled with orange and black, and is by no means uncommon. If the green lizard were as highly endowed with intelligence as it is with a wonderful power of reproducing lost organs, it would rank with the "most subtil" of creatures. The naturalist, Blumenbach, destroyed the eyes of some, and found those organs completely restored after the lapse of some weeks. Of course no one is rash enough to ascribe this remarkable restorative process to any peculiar skill possessed by the animals; but a mysterious power must, it is evident, be at work in the physical constitution of these active little creatures.

Lizards are social beings, and are sometimes found in countless multitudes, dwelling together in perfect harmony. When Mr. Bruce visited the ruined Temple of the Sun at Baalbec, his attention was for a time directed from those wonderful ruins by the hosts of brightly-coloured lizards which had taken possession of the once magnificent house of Baal. These nimble reptiles were basking by thousands in the sun. They swarmed on prostrate columns, and darted in every direction over the Cyclopean granite masses 
of the temple walls. In such silent and lonely places these little creatures show the strength of their social tendencies. What a startling change is here! Syrian lizards finding a sunny home in the courts once crowded by priests of Baal.

One family of lizards, the geckos, are furnished with feet so complex in structure, that none but "clever animals" could use such elaborate walking machines. These feet are formed of a series of muscular layers, fringed with a sucker-like apparatus, and sometimes furnished with a sharp and hooked claw. The geckos are thus enabled to cling not only to walls, but to the smoothest surfaces, and to run along ceilings like the house fly. These reptiles know how to avail themselves of this peculiar organisation. Is a gecko hungry, it suspends itself, back downwards, to the under side of a large leaf, and waits, even for hours, until an insect comes within reach. Here, then, we find an animal provided with a delicate tool-for such the gecko's foot is-and we also see that the creature uses this instrument in the most effective manner. If a mechanic has a thorough command over his tools, do we not deem him a skilful workman? Why, then, should we hesitate to admit a degree of intelligence in a reptile which uses its own special tools in the most perfect manner? This adhesive power of the gecko's foot is not, of course, a mere mechanical result. The animal has to use rightly the numerous muscles by which the fan-like foot is expanded, and also those which draw the fleshy fibres close to the diversified surfaces of the bodies to which the lizard clings. These remarkable feet, and the reptile's intelligent use of them, early attracted the attention of the ancient Jews and Arabs. The Hebrew name for the lizard (Letââh) 
is generally derived from an Arabic root, signifying to cling. The "spider" described in the Book of Proverbs (xxx. 28) as taking "hold with her hands," and living "in kings' palaces," is probably the gecko, which is found in the most secluded parts of royal Eastern mansions. The cool manner in which these lizards await the near approach of a foe, and then suddenly disappear, indicates a degree of watchfulness combined with courage, which would be called "presence of mind" in a human being. A man sees a gecko on a wall, he resolves upon its capture, and slowly the hand or net approaches. The bright eyes of the little lizard are fixed on the coming peril; there is no sign of stupid fright in the creature-only a keen observation of the enemy's motions. Just as the swoop is about to be made, the creature disappears, as in the "twinkling of an eye." The disappointed man may, for a moment, be at a loss to trace the lizard's place of refuge; but he sees, after some search, a small chink between the time-worn stones of the wall, into which the creature has darted, and where it is safe from human fingers. The defeated man probably goes away with the reflection that the lizard has intelligence enough to baffle him. 


\section{TORTOISES.}

THE land tortoise has ever been chosen as a symbol of slowness, both in motion and understanding; the sea tortoise, or turtle, may be regarded as emblematical of prudence. This virtue, says Lacépède, which in animals is the result of the dangers they have encountered, need not astonish us in these tortoises, which are the most sought.

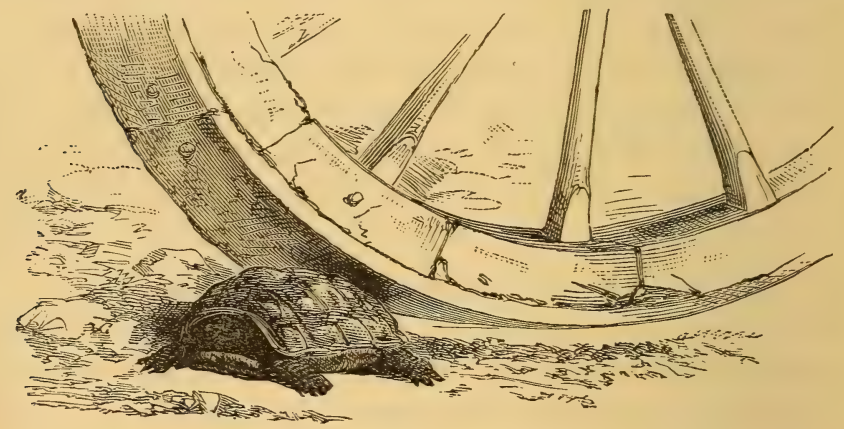

Tortoise under a Wagon-wheel

the danger in hunting them being little. The tortoises are covered with a complete suit of bony armour, the upper part being called the "carapace," and is of so hard a nature as to stand the pressure of extremely heavy weights. Even a wagon-wheel has passed over the animal without breaking its tough and firm covering. Mildness and capacity of endurance are the distinguishing characteristics of the green tortoise or turtle; and these qualities may have induced 
the imaginative Greeks of old to make it a symbol of beauty, and Phidias to place such a creature at the feet of his Venus. We may here remark how wonderfully the character of the tortoise coincides with the formation of its body: its habits are as regular as its shell is solid. Being more passively than actively inclined, the tortoise rarely experiences any strong desires; more prudent than brave, it seldom defends, but rather tries to shelter itself, and employs all its strength to cling to the ground when we endeavour to raise it by the shell.

The sluggish motions of the common land tortoise may lead many persons to underrate the intelligence of such a "ridiculously slow" creature. This tardiness of progression arises from the animal's peculiar structure, and is no proof of dulness. Examine the legs, they appear like crutches; notice the feet, they form a strong grappling apparatus for pulling along a heavy weight; but who would expect swiftness from such toes? Some large tortoises do, however, make long journeys with more rapidity than we should have thought possible. Those in the Galapagos islands were found by Mr. Darwin able to travel four miles a day-a rate of progress not despicable in a creature provided with such legs, and so heavy that six men were often required to lift one. But we must not forget that this slow movement is characteristic of the land tortoise only; those inhabiting the waters swim with rapidity and ease, turtles having been found 2,000 miles from land.

Though the tortoise is slow of foot, it is quick in using all its available modes of defence. See how completely the animal withdraws head and feet within the protecting cover of its strong shell, in which, as in a castle, the tenant may defy every foe, except man. The box tortoise (pyxis) pos- 
sesses a very singular defensive apparatus, which it well knows how to use. The plastron, or shell, covering the under part of the body, is so formed that its front segment can be drawn upwards so as to protect the animal's head when this has been drawn back under the carapace.* The upper and under shells then meet in front, forming a kind of box, in which the creature is unassailable. When the danger passes away the reptile relaxes a muscle, the raised part of the plastron then falls, allowing the head and forefeet to come forth. This movable plate is fastened to the plastron by a strong hinge of elastic ligament. The effective manner in which the tortoise uses its remarkable defensive door, indicates as much of watchful intelligence as the circumstances require.

If the tortoises possessed the utmost powers of flight, they would be foolish to run from their enemies, having such impregnable fortresses in which to take refuge. It is surely no proof of stupidity to make the best possible use of the means at hand. This is just what the tortoise does.

It may be said that the turtles must be stupid to allow the hunters to turn them over on their backs by long poles, when they must remain on the spot, being unable to recover their natural posicion. But the turtles are, in this case, subjugated by man, with whose skill the most cunning animal cannot effectually contend. Besides, these reptiles are perfectly aware of their peril if thus overturned. When two turtles engage in battle, the great object of each is to upset his opponent. This being accomplished, the victor marches off in triumph, feeling that his foe is powerless. These creatures are, therefore, quite aware of the weak point in

- The shell on the back of the tortoise. 
their organisation. Thus much, at least, of "self-knowledge" even turtles possess. Some of the American river tortoises (Gymnopus spiniferus) show so much cunning and energy in attacking the fishermen, when caught, that the men can only secure themselves from dangerous bites by cutting off the heads of these reptiles as soon as possible.

Few animals seem more impassive than the common tortoise, but those who are able to watch its movements know that the creature is really very sensitive. What can it feel, some may ask, of atmospheric influences, covered with that insensible shell? The actions of the tortoise give the reply. A few drops of rain will send it home with all speed; even the distant approach of a shower makes it uneasy. Hence Gilbert White remarked that his tortoise showed "as much solicitude about rain as a lady dressed in all her best attire." The bright light of the sun seems to be especially grateful to tortoises. Rarely will they stir out at night, and the approach of winter drives them into their retreats till spring returns. This physical sensitiveness shows a temperament less sluggish than is commonly supposed.

The animal also learns to recognise persons, remembers those who feed it, instantly distinguishing them from strangers. Here, therefore, we find memory exercised, and some degree of discrimination is clearly shown. The common tortoise has also skill enough to make for itself a winter home in the ground, and, when spring comes, forms a hole in the upper part of its cell in order to obtain a supply of air without leaving the house when the weather is cold.

The turtles, too, exhibit some degree of contrivance in forming the nests for their eggs. These are not mere hollows scooped out in the sand, but resemble the ovens of half-civilised tribes. Over the hollow in which the eggs are 
deposited earth is placed, so as to form a covering which may protect the contents of the nest from the chilling damps of tropical nights. This arch-like cover is not thick enough to exclude the heat of the sun, but quite sufficient to retain much of the warmth during the night. Nor is the position of these nests on the shore a matter of indifference; they must be placed above high-water mark, or the next tide would sweep away the eggs.

The tortoises in tropical islands require much fresh water for drinking, and have often discovered springs of which the inhabitants were ignorant. When these animals have found such a fountain, the whole surrounding district is soon covered by "tortoise roads," made by these large reptiles in their frequent journeys to and from the waters. Some of these springs flow from volcanic rocks at a great elevation, but the tortoises generally discover them.

The brain and nervous system of these reptiles have been carefully examined by great anatomists, and the experiments on the living animals will appear to some readers exceedingly cruel. As the results prove only the extraordinary vitality of the reptiles, and have little connection with their intelligence, the briefest notice will suffice. A common land tortoise moved about with apparent ease for more than six months after its brain had been entirely removed. The eyes closed after the operation, but the vital powers of the animal seemed little affected in other respects. In two of these reptiles the heart continued to beat and the blood to circulate for twelve days after their heads had been cut off. It may well excite surprise that such extraordinary tenacity of life should be generally found in animals possessing a low intelligence. A mammal will die in an instant from a wound which a tortoise would survive for half a year. 


\section{THE SALAMANDER.}

Why did Francis I. adopt, on one occasion, the salamander in the fire for his device, with the motto- "I live in and extinguish it?" There was here a twofold allusion-one pointing to an ancient superstition, the other to the perilous position of the king himself and his hopes of victory. Francis probably believed that the salamander could really live in the fire, or at least could endure the flames unharmed until it extinguished them. By adopting so strange a device he plainly intimated to friends and foes that, though surrounded by dangers, he should escape harm, and finally triumph. Let any reader take up one of our British salamanders, either the large or small water newt, or eft, as the rustics call it, and observe the timid, harmless creature, about which such marvels were formerly believed. It could live in the fire, said most men; it would poison the vegetation of a whole region, was the gloomy declaration of Pliny; its venom was deemed so deadly, that a proverb uttered the terrible warning, "if a salamander bites you, put on your shroud." The orchard-keepers dreaded its approach, believing that if it should touch but one apple the whole tree would be infected. The farmer abhorred the creature, supposing that it sucked the milk from his cows. In truth, nearly all men looked upon the unlucky reptile with horror and hate, as furnishing the most deadly spell for the witches' incantations. Thus the poor salamander had gained for itself the honour of being the most hated animal 
on the earth. There were a few, indeed, who endeavoured to extract good from its body; but they rather increased the perils of the persecuted reptile. The heart, being placed in a small casket and worn round the neck, was deemed a protection against fire, and a preservative from contagious disease. Even man's love of gold brought misery to the salamander. The alchymists - who were in fact the fathers of chemistry-believed that if quicksilver were poured on a roasting salamander the metal would be turned into gold. The sins of the experimenter might, indeed, prevent the transmutation; and it is to be feared that all the operators were great sinners, as their attempts seem to have universally failed.

Was the salamander the most stupid, or the most clever of reptiles, that it incurred such persecutions? Neither attribute was the cause of its calamities. The fluid which it sometimes pours from its skin, may have slightly damped the heat of burning fagots, or have raised small blisters on the fingers of its persecutors, and from such occurrences the credulity and ignorance of mankind drew up a terrible list of horrors.

All the salamanders do, however, possess a power which we, in the nineteenth century, must call mysterious, and which the ancients might well have deemed supernatural. No creatures reproduce destroyed organs in a greater degree than the salamanders. This has attracted the attention of the greatest physiologists, and baffled the scrutiny of human science. Our large water newt (Triton cristatus) will not only survive the amputation of tail, legs, eyes, and head, but will reproduce nearly all the destroyed parts in their original perfection. But such renovating energies are rather physiological mysteries than signs of intelligence; we will, there- 
fore, now mention one process which suggests that even our common newt is endowed with something like reason. The female forms a separate cradle for every egg deposited; she selects the leaf of some water plant, especially one of the joint-worts (polygonum persicaria), and bends it until the under side is brought in contact with her body. An egg is then glued to the leaf, the end of which, being folded back on the after-part of the leaf, forms a well-contrived case. The folded part is prevented from returning to the straight position by a gummy secretion, with which the newt glues the sides of the inverted leaf together. These bent parts of the plant are easily observed by those naturalists who are familiar with this animal's ingenious mode of protecting her eggs. In this process we may note the following stages of an intelligent work. First, the selection of a leaf fitted for the purpose; then the gluing the egg firmly to prevent the water from carrying it away; next follows, in most natural order, the work of making the cradle by folding the leaf back. Did the reptile stop here, the whole of the previous work might be in vain, as the elasticity of the vegetable fibres would soon bring back the leaf to its natural position. This is prevented in a mode thoroughly rational ; the reptile worker fastens the folded part down, and thus the object is secured. Every step in this operation proceeds as reason would dictate. 


\section{THE DOMESTICATED TOAD.}

WE shall. finish this chapter on reptiles with a short account of a toad which lived more than thirty-six years in a hole beneath the door-step of a French farm-house. How old it was when first noticed no one could say, but it had probably lived a long time before familiarity with the sight of man emboldened it to rest tranquilly on the door-step, over which many persons were constantly passing. The step became, in reality, the reptile's hunting-ground, where, with little trouble, it might capture the ants which persisted in crossing and re-crossing the step. The toad "hunting for its supper," became one of the regular sights of the neighbourhood, and certainly the skilful manner in which the creature used its wonderfully formed tongue, left an impression upon all spectators that this toad was a most clever insect-hunter. Four particulars, especially, fixed the attention of the more thoughtful observers. It was soon evident that the toad was most skilful in judging distances; the tongue was never darted at an insect until it came within a certain range-this space was never miscalculated. The accuracy of the creature's aim was another matter for surprise. The insects were generally, if not always, in motion when the tongue was darted out against them; but the arrow never failed to hit. The singular rapidity with which the organ was shot forth excited equal wonder. Many curious watchers were unable to note every motion; only a few of the keener eyes could manage this. Yet this 
operation was a complex one. The tongue is doubled or folded up when in the mouth; there is therefore a twotold action required-an uncoiling of the weapon, and then the darting out process. The withdrawing of the tongue, with the captured insect on the tip, was not less remarkable thar: the other operations. Notwithstanding the rapid motion, the fineness of the tongue tip, and the struggles of the prey, the captured victim was never dropped.

Now it is clear that, in all this hunting work, the toad intelligently employed two instruments in harmonious cooperation-the eye and the tongue. The one never failed the other. The rifle-shooter knows how much practice is required before eye and hand act perfectly together; our domesticated toad had gained this power over the combined action of two dissimilar organs.

The tameness of this toad was so remarkable, that we may justly call the animal "domesticated." It would remain quietly in one hand, and take its food from the other, provided a leaf were placed on the hand which held it. Without this precaution, the warmth of the human skin evidently annoyed the cold reptile. Few things seemed to please the animal more than placing it on a table in the evening when the lamp was lighted. It then, with the greatest confidence, would look round with its gleaming eyes, and when insects were placed on the table, snapped them up with a rapidity which seemed greater than in its day huntings.

In this way the animal lived for thirty-six years, in or near the house, the pet of the village and the neighbourhood. It might have lived for as many years more, had not a tame, but spiteful and jealous raven pecked out one of the toad's eyes. The vindictive bird brought upon himself universal hatred for this "assault, battery, and maiming;" but this 
sympathy was no profit to the reptile. Then we saw how much the proper use of its tongue depended on the sight. The toad could no longer measure distances accurately, or aim with certainty. A newt might have restored its eye, but this was beyond the science of our reptile, which died in about a year after the injury, apparently from starvation. 


\section{F I S H.}

THEIR INTELLIGENCE - VARIETY OF THEIR DWELLINGPLACES- LITTLE PARENTAL FEELING-COURAGE AND ACTIVITY IN SELECTING SPAWNING-GROUNDS-MEMORY - LONG LIFE-RESEMBLANCES TO BIRDS-BRAINSEYES-TOUCH-INTELLIGENCE OF THE MILLER'S THUMB - SKILL OF THE STICKLEBACKS AND THORNBACKSSOCIABILITY OF PERCH-ABILITY OF THE SHOOTING FISH-INTELLIGENCE OF A PIKE-HABITS OF THE SEAHORSES-THE SHARKS-STRATAGEMS OF THE TURBOTS, EELS, DILK-HEADS, AND DART-FISH.

FIsH do not exhibit many of the signs of animal intelligence. The element in which they live may, indeed, prevent us from observing them closely. Many proofs of fish skill and tokens of ingenuity may be hidden in the sands of rivers and the depths of ocean. We do undoubtedly discern a certain amount of watchfulness and cunning in our common river fish. How slily does the trout lie in wait for the plump gudgeon! how warily does an experienced fisl swim round and round the bait, scanning it from every side with a scrutiny which says, "there's something suspicious here!" Practised anglers will recall many cases in which the most seductive baits and the most enduring patience have failed to hook some sagacious "fourteen-pounder." But, nevertheless, the intelligence of the fishes is not ranked very high by naturalists, though it may be questioned whether some have not placed the acute- 
ness of the order too low. One compares a fish to a "stupid old man with a softening brain," a comparison which shows little observation in the writer himself. "The low forehead and heavy head" are also pointed out as the signs of stupidity in a fish. Such naturalists forget that the form of the head in these animals is adapted to facilitate their motion through the water, and has little, if any, influence on their intelligence. This must be inferred from the creature's habits rather than from the shape of its skull. The question whether fish have not less cunning than reptiles has been proposed, but who can give an answer which shall be supported by satisfactory proofs? Cases might easily be selected of clever fishes and dull reptiles by one person, while another could produce an equal number of subtle reptiles and foolish fish.

The dwelling-places of these "people of the waters" are exceedingly varied, and each must require the exercise of instincts and habits suited to the localities in which the fish makes its home. Some delight in the mud, some in stagnant waters, and these seem dull and lazy in the daytime; but, as many are night feeders, their activities are concealed from our observation. Some frequent rippling brooks, where the clearest waters roll musically over silvery sands; others delight in the strong currents of deep tidal rivers, sporting near the surface, or luxuriating in the warm depths of the water. Some, like the salmon, inhabit alternately the fresh and salt water, frequenting the rivers in summer, and returning to the sea for the winter. One family of fishes possesses also the power of "flying in the zir," or, at least, of sustaining themselves by the action of the large and outspread fins during a flight of two hundred yards. Now this great variety of waters and changes of 
locality seem to require in fish an equal diversity of instincts and capacity of adapting themselves to changes. But such power of accommorlating itself to circumstances is rarely found in a stupid animal.

Fishes, it is said, have none of that training of their instincts which the bringing up of their young affords to so many animals. This remark is perfectly just. There can be no doubt that the necessity of providing for the young is a most potent educator of animal instincts. Fish are undoubtedly deprived of this powerful stimulus, and the reason is clear. Their children are too numerous to admit of such care. It is easy for the active swallow to tend her three or four nestlings, but what would a fish do had she to watch over a million of hungry young ones? When, therefore, the herring or salmon leave their almost countless eggs to be hatched on rocks or sands, they are simply obeying a law of nature, which commands them thus to act.

It cannot, however, be said that even fisin are entirely without regard for their race. If we admire the zeal with which a bird constructs the nest-a place of safe deposit for her eggs-we cannot entirely overlook the energy with which the salmon forces her way up a stream, until she finds a place suitable for the reception of the ova. In this attempt the fish will contend with currents, leap up waterfalls twenty feet high, and brave every peril. To this extent, therefore, these animals are brought under the influence of what is in them the maternal feelings. It is this impulse alone which brings every year to our shores such countless myriads of herrings and mackerel from their usual homes in the deeper waters. It may, however, be said that these migrations are no proof of intelligence, but only of a 
blind instinct. This conclusion is certainly not true in all cases. The salmon does undoubtedly show intelligence in surmounting the obstacles to her progress in rocky streams. Fish, too, are acute enough to abandon their old haunts when unusually disturbed. They are not, therefore, altogether led in these migrations by a blind instinct, but select or reject certain waters, according to circumstances.

The ingenuity shown by young eels in overcoming the obstacles to their progress up a river, even climbing up locks and floodgates, is another proof that these inhabitants of the waters are able to devise special methods of overcoming special difficulties.

The possession of a strong memory by fish is proved by the return, over long distances, to the waters where they were hatched. Salmon have often been marked before going to the sea, and the next year have been found in their old haunts.

We must not forget that the long life which is granted to fishes must at length develop in old ones a high degree of prudence or cunning. Every angler knows the difference between the heedless dash of a young trout at a bait, and the suspicious approach of an old and experienced "lord of the river." If we grant that fish are the most dull of animals, we must also admit that longevity gives time for drawing out and stimulating even sluggish instincts.

Thus, if the higher life of intelligence be less developed, or at least more retarded, the animal life is longer; fish gain in longevity what they lose in intensity; so they would not have uttered the maxim, "Life, short and sweet." Constantly plunged in water, the fibres, the bones, and the tissues of fish preserve for a long time their flexibility. The progress both of growth and decompusition is more retarded. 
and the ossification less rapid, as the cartilaginous skeletons of fish show.

By their organisation, they form a race of beings between the articulated and the vertebrated orders, and are very interesting subjects of study. They form one link in a great family of animals, of which the birds are another, and to which they have a great and peculiar resemblance, both being inhabitants of fluids, in which they move with equal activity and ease.

Fishes, said Virey, may be regarded as birds of the sea, and birds as fishes of the atmosphere. The wings of the one are represented by the fins of the other, and the feathers by scales. If there are aquatic birds there are also aerial or flying fish. Swimming and flight are nearly the same act, executed in two different fluids; the fish flies in water, as the bird swims in the atmosphere. If the winds assist the flight of birds with feeble wings, the currents of the sea aid the weak fins of fish, while the stronger species of both orders brave the currents of the ocean or the tempests of the air.

As there are some birds unable to fly, there are also some fish which cannot swim; there are, again, some which live in society and others which prefer a solitary life. The annual migration of fishes to the depths of the sea is not less regular than the migration of birds to distant lands. Both travel in large numbers to other regions, either to gather more abundant nourishment, or to reproduce the species in peace. Each returns to its first country, and it is at these seasons that man makes such havoc among the singing birds of the air and the dumb inhabitants of the deep.

Strong contrasts are also evident between these was 
classes of animals. The bird is less prolific than the fish. The latter has the flesh less firm, the muscular fibres feeble, and is apathetic; the former is remarkable for physical energy and high excitability. The bird is attached to its family, loves, attends, and nourishes it; the fish has no attachment for its young, and abandons them without regret. Birds naturally abound in the Northern Hemisphere because there is more land; while in the Southern Hemisphere fishes predominate on account of the extent of water.

If the tropical birds are enriched with splendid colours, the fishes of the equatorial seas are not less brilliant. Cuirasses of gold, silver, azure, rubies, and emeralds, sparkle in the waves like precious stones under the light of the sun; but these splendid decorations often vanish at death, while the colour of the feathers does not thus fade among birds. Fishes change their colours and scales according to their age, sex, and seasons; birds also moult their plumage and lose their diversity of tint from the same causes. As birds indicate the coming of tempests by their peculiar flight, so fishes by their unquiet movements announce the approach of storms, and rise to the surface of the water when it is likely to rain.

This great resemblance between these two classes of animals depends no doubt on the medium which they inhabit, for fluidity being common to air and water, we should expect a resemblance between the beings which are found there. Nature is obliged to follow the path set before it, as if an invisible hand had traced the route through which it must pass in all ages.

As the habits, manners, and intelligence depend on the nervous system, we shall have a better idea of organic per- 
fection and the more or less development of sensibility and intelligence by considering this in fishes.

The central parts of the nervous system in fish are composed, like that of vertebrated animals, of the brain and the spinal marrow. The brain is lodged in the cranium, and the spinal marrow occupies the vertebral canal, filling the whole length. There are only a few exceptions to this remark ; we may mention the sea-devil or frog-fish, and the moon-fish, in which the spinal marrow is extremely short.

But considering the largeness of the head in fishes, and the capacity of their cranium, the brain is rather small. As there is a harmony between the extent of the intellectual manifestations and the development of the brain, we find evidence enough to support the opinion that fishes are creatures very imperfectly gifted with intelligence.

The brain, instead of being close to the inner surface of the cranium, as among the superior animals, occupies a very limited space in the skull. A slight shake suffices to displace it if there is not sufficient oily matter to fill the empty space. The brain of fishes is marked by the feeble centralisation of the parts; the functions of the nervous centres appearing to be less localised than among the higher vertebrated animals. See how this proves that the organisation influences the intelligence, and that it is not only necessary to consider the volume, but also the density and composition of the brain. Fishes whose brains nearly approach those of the higher vertebrated forms are the skates, and those known scientifically under the name of plagiostomes." Their cerebral hemispheres are strongly developed, and, above all, very large, but do not fill the skull. The two

- A word signifying uneven jazes, and including the shark family. 
inferior lobes, the optic lobes, and the cerebellum* are well developed. The brains of carp are larger than those of other fish in proportion to the size of their bodies. This proportion in the carp is as I to 500 , the same as in the elephant. If it were easier to observe the manners of these animals, we might, without doubt, see among them signs of intelligence in accordance with the development of their brains.

In a very interesting notice on the brains of fishes, M. Holard has shown that these comprehend every part which exists in the brains of superior animals. We must not forget the experiments of Magendie and Desmoulins, or those of M. Flourens, by which these physiologists attempted, by cutting and removing certain lobes of the brain, to observe the true functions of this organ. Lastly, Dr. Baudelot has proved that fishes do not appear to be incommoded by the destruction of the hemispheres of the cerebrum.t The animal seems even then to preserve all its faculties, and moves with the same agility and the same certainty as before the operation. The result is very different from that produced upon mammalia, or among birds, in which the removal of the hemispheres would cause a profound stupor, and an annihilation of the intellectual faculties.

Fishes have some well-developed senses. Every one has remarked the convex shape of their eyes, which fits them to see in the water, and is adapted to the peculiar refraction which a ray of light undergoes in passing through so dense a fluid. The range of their vision being extended, and the survey accurate, they dart with amazing certainty

* The small inner brain.

+ The outer and larger part of the brain. 
upon a bait. All fishermen will tell you what precautions are necessary in approaching the water, in order not to frighten the fish. The Romans, who did not care much about fish except to eat them, had nevertheless remarked the acuteness of hearing in these animals. It delighted them to give particular names to the inhabitants of their fish-ponds, and they were successful in making each one come at the sound of its name. The sense of smell appears to be very refined and very perfect among the inhabitants of the waters. Their olfactory nerves are strongly developed, and experiments made by Mr. Jesse prove the acuteness of their smell. He fed fish in a basin, and noticed that these animals preferred paste and worms which had been prepared with certain perfumes. This fact is not unknown to anglers, some of whom soak their baits in odorific substances to stimulate the appetites of the more luxurious fishes.

Who knows whether fishes do not owe their littledeveloped intelligence to want of taste and of touch? What can we expect from beings who have no taste? Therefore fishes do not eat, they swallow. It is only people of sense, said a celebrated gastronomer, who know how to eat!

If fishes want the sense of touch they have but little occasion for its exercise. Existence for them is not very difficult, they have only to give way and go down the river of life. The inhabitants of the waters also appear very insensible ; never have we seen a fish shed a tear!

But to preserve himself and to ensure the existence of posterity, the inhabitant of the waters does put off his carelessness and his intellectual torpor. Look at the miller's thumb, called the bull-head. It has a large head, 
at least as wide as it is long among the old males, a little flattened above, forming not less than a third of the animal. Its eyes are smaller than the eyes of most other fishes, but tl.ey are sharp, and placed near the top and towards the side of the head, so that a wide survey is taken at once. With such a head, and such an extended view, this fish might be expected to possess a high degree of acuteness. It has been shown that the miller's thumb is usually too intelligent to take the bait. In order to capture the fish the fisherman is obliged to use a net, which is dragged along while he overturns the stones and stirs the sand, either with his feet or with a stick, to dislodge the fish hidden in the cavities, and to force them into the net. Three men are necessary to put this plan perfectly into practice, even in a small river; whilst two drag the net up the stream, the third goes before, stirring the ground with his stick in the direction of the net.

See the intelligence and the care with which the stickleback constructs its nest. M. Emile Blanchard relates, that towards the first days of June, under ordinary circumstances, the male stickleback seems to be looking out for a convenient place. He keeps moving a long time about the same locality, frequently quitting it and then returning. After having stopped and determined on a place, he digs with his snout into the mud at the bottom of the water, and ends by burying himself there. Then, working vehemently, and turning with great rapidity round and round, he forms a cavity, which is bounded by the earthy matter thrown out at the edges. This first part of the work executed, the fish withdraws himself, looks on all sides, and is evilently in quest of something. A little patience yet, and you will observe him seize between his teeth a vegetable 
thread or filament of a root. Then, holding this in his mouth, he returns directly to the little trench which he has dug. He there places the thread, fixes it with the aid of his snout, taking some grains of sand to keep it in position, and rubbing it with his belly on the ground. When he is assured that the fragile filament will not be washed away by the stream, he goes to seek more, and adjusts this as he did the first. The same work is repeated over and over again, until the bottom of the trench is covered with a sufficient bed of weeds. The time arrives when the layer is thick enough; all the parts are attached one to the other very nicely, and are well trimmed, because the stickleback has rubbed the ends with the mucous matter which exudes from openings along his sides. That which charms the attentive observer is the intelligence which appears to preside over the lesser details of the operation. In placing the materials, the fish seems at hest simply to heap them up; but when once the first row is fixed, he disposes them with more care, arranging them to suit the opening at the entrance of the nest. If the work is not perfect, the clever workman draws the defective pieces out, fastens them, and works away until he has assured himself that all is as he wishes. Amongst the materials brought, those which have an inconvenient form or size are immediately rejected. The stickleback rapidly moves his fins to produce strong currents, as if he would assure himself of the solidity of his edifice, and that none of it can be washed away. This is not all. The foundations of the nest are laid, and in order to complete the edifice our architect must travel much; but his perseverance does not abate. He continues to procure materials, shapes the sides and bottom of the trench, ornamenting them with weeds, 
pressed and crossed the one over the other. The stickle. back always glues these together with the utmost care.

He introduces himself between the two upright walls, leaving a cavity large enough for the female to pass without

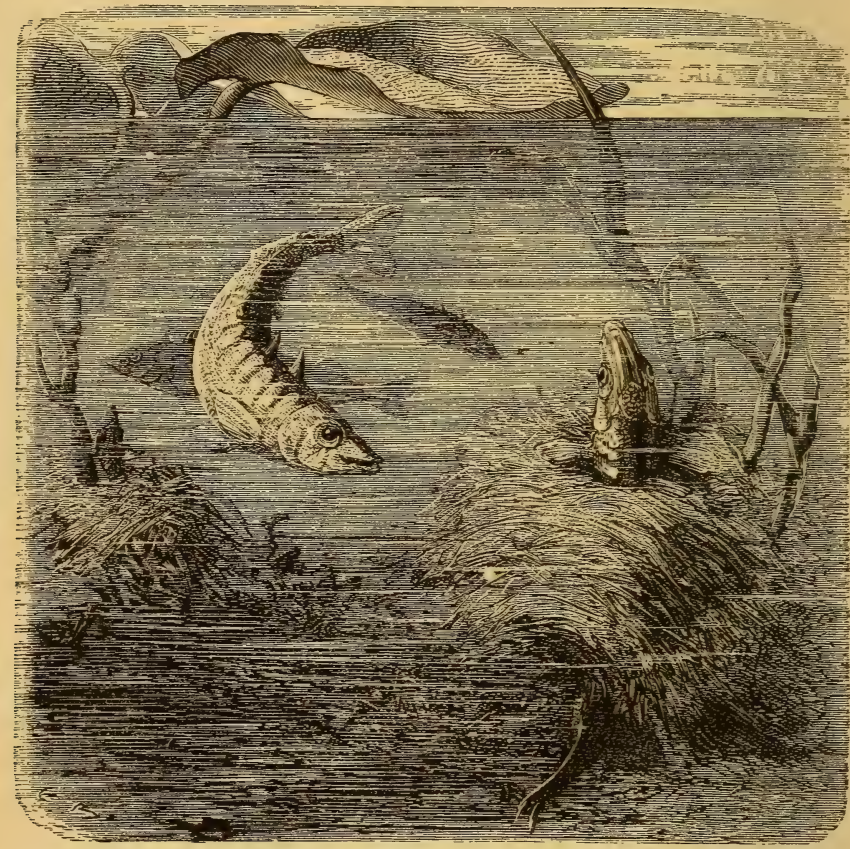

The Stickleback and its Nest.

difficulty. He then proceeds to construct the roof. Fresh weeds are brought and placed upon the top of the walls already formed, and then fastened at their extremities. The fish always pursues his work in the same manner, fixing and turning the grass blades with his snout, trimming e walls of the edifice, and agglutinating them with the 
gummy fluid pressed from the pores of lis body. The cavity is particularly the object of his care; he rectifies many mistakes in it, until the sides of the nest are well formed. Sometimes the domicile is closed at one of its extremities; but more often it is open at both ends. The opening opposite to that by which the animal enters so frequently to accomplish its work is allowed to remain very small. It is constructed with the utmost care; not one blade of grass projects beyond another; the surface is glued and polished with the most minute precautions, to render the passage easy.

If the different species of the true sticklebacks act in exactly the same manner, the method of working differs in some species of the great division of thorn-backed fishes. The male in every species is always the sole architect, and he shows no less skill, no less vigilance than the true stickleback. He fixes his nest at a certain height from the bottom, among the stems or on the leaves of the plants which interlace in the waters. He makes choice of most delicate materials-water weeds, very light or very delicate filaments of herbs. He carries these to the place where he intends to construct his little edifice; taking wonderful care to make them stick to the vegetables on which they are to remain, and to prevent them from being carried away by the stream. He employs in this case the same means as the stickleback, fixing the materials with mucous fluid by rubbing them with his body. When the mass of herbs and weeds is large enough, the fish forces himself into the middle with his snout; he is soon hali buried, but continues to advance more and more, working with his dorsal spines, which separate the filaments one from the other. At length he makes his exit by an open. 
ing opposite to that at which he entered. At this moment the nest has taken its definite form, and may be compared to a muff. The edifice is finished when the walls of the tube are lined and the entrance smoothed. All this is done by the same means as we have seen are employed by the stickleback.

The vital energies of the sticklebacks rank high. They can endure a direct transfer from fresh to salt water, a change which would kill many fish.

Sticklebacks and thornbacks are not the only fish which imitate birds in making nests for their eggs. Gold-fish construct their nests with leaves; but sometimes a hole is dug in the river bank. The father and the mother watch in turns with devoted attention, and defend with courage their future family. This display of parental feeling is to be especially noted, as it is exceedingly rare among fish.

Other marks of intelligence show themselves in these animals. We know that it is the character of intelligent beings to live in society. The perch is eminently sociable. A great number of these fish form a shoal, as if a sort of treaty had been signed between them. In a time of calm we may observe them in large bodies in a lake, a river, or under banks, where they keep themselves near the surface of the water, and are stationary. But their sense of hearing is very acute, and the least unaccustomed sound makes them take to flight. They disappear rapidly, and flee to some spot which is the common hiding-place of the whole. They have been found twenty or thirty in the same place, and in certain cases all have been taken, one after the other.

Other fishes show an address which surpassss that of 
the most intelligent men. A species of the chætodon,* better known under the name of the shooting-fish (Chelmon rostratus), has a very long narrow tube projecting from its head. It frequents the shores of the sea and the banks of rivers to obtain food. "When," said Dr. Jonathan Franklin, "it sees a fly perched upon a water plant, it swims up to within the distance of four, five, or six feet, then, with a wonderful dexterity, shoots from its mouth a drop of water, which never fails to strike the fly and knock it into the sea, where it becomes a prey to its enemy."

The recital of a deed so very uncommon roused the curiosity of the governor of the hospital of Batavia, in the isle of Java. The fact was attested by credible witnesses, but he refused to believe such reports. $\mathrm{He}$ ordered a large jug to be filled with sea-water, and, having many of the fishes, placed them in the jug, changing the water every day. In a short time they were reconciled to their state of captivity; then the governor resolved to commence his experiment. He took a slender rod, at the end of which he fixed a fly with a pin, then placed this stick on the side of the vessel, so that the fish might see the insect. It was with a sentiment of inexpressible joy that he saw these fishes exercise their power in shouting with a marvellous velocity at the fly, never missing their mark.

The jack, or pike, of our rivers, gives signs of intelligence and of sentiment. "Do not smile at this alliance of words," said Dr. Franklin. "The sentiment of the pike! Are not the most ferocious mammalia often those which show themselves most capable of attachment and intimate association with man? Why should it not be thus with the finny tribe?" The following anecdote was read, in 1850 ,

* A word signifying fine teeth, like bristles. 
before a learned assembly, the Literary and Philosophical Society of Liverpool :-

"When I lived at Durham," read Dr. Warwick, "I was walking one evening in a park belonging to the Earl of Stamford, along the bank of a lake where fishes abounded. My attention was turned towards a fine jack of about 6lbs., which, seeing me, darted into the middle of the water. In its flight it struck its head against the stump of a post, fractured its skull, and wounded a part of the optic nerve. The animal gave signs of ungovernable pain, plunged to the bottom of the water, burying its head in the mud, and turning with such rapidity that I lost it for a moment; then it returned to the top, and threw itself clean out of the water on to the bank. I examined the fish, and found that a small part of the brain had gone out through the fracture of the cranium.

"I carefully replaced the shattered brain, and, with a small silver tooth-pick, raised the depressed parts of the skull. The fish was very quiet during the operation; then I replaced it in the pond. It seemed at first relieved, but after some minutes it threw itself about, plunged here and there, and at last threw itself once more out of the water. It continued thus to act many times following. I called the keeper, and, with his assistance, applied a bandage to the fracture. This done, we threw the fish into the water, and left him to his fate. The next morning, when I appeared on the bank, the pike came to me near where I sat, and put his head near my feet! I thought the act extraordinary, but taking up the fish, without any resistance on its part, I examined the head, and found that it was going on well. I then walked along the banks for some time; the fish did not cease to swim after me, turning when I 


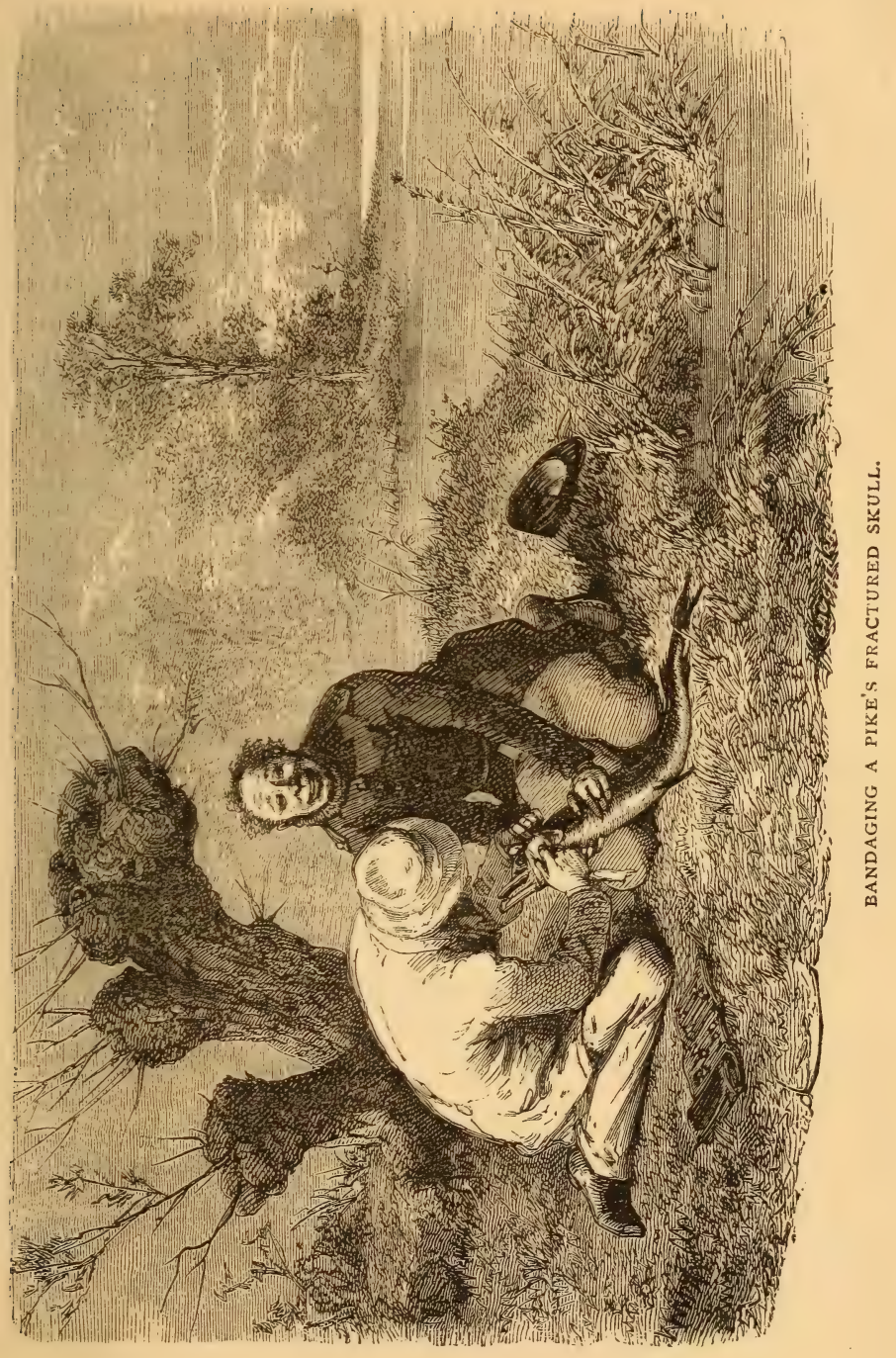

G 2 

turned; but as it was blind on the side where it was wounded, it appeared always agitated when the injured eye was turned towards the bank. On this, I changed the direction of my movements. The next day I brought some young friends to see this fish, and the pike swam towards me as before. Little by little he became so tame that he came when I whistled, and ate from my hand. With other people, on the contrary, it was as gloomy and fierce as it always had been."

"The history of this knowing pike is a hint from nature," says Dr. Franklin, "and suggests some new ideas of faculties which may be given to fishes. It is to be regretted that the element in which fishes live is such that we are not able to make an intimate acquaintance with them. It would be ridiculous to say that the barrier is passable; but in certain cases, as we see, it is not man who goes to the fish, it is the fish which comes to man."

Another sign of the intelligence of animals is their capability of being tamed. The cod-fish-who will believe it?-is one of the fishes which appreciates the society and the caresses of man. It may be taken in the hands, and caressed, if you do not forget to flatter its appetite with some victuals. Oh, the mighty stomach!

It is often to the smallest beings that we must look for intelligence. Certain small fishes called sea-horses (Hippocampus), which live in the Mediterranean, and whose habits have been closely observed by Mr. Lukis, have given manifest signs of intelligence. This observer kept in a glass vessel two female sea-horses. "I saw that these fishes sought a place for repose. I satisfied their desires by placing in the vessel the stems of some sea-weed; this was what they wanted. They then displayed their true 
habits, and I ought to say that no inhabitants of the deep show themselves more acute than the sea-horses. When they swim, these fishes preserve a vertical position, but their tail is ready to seize upon whatever is found in the water, often clinging to the reeds, the fish thus holding on with their tails. Once fixed, the animal observed all the objects around, and darted on the prey with great dexterity. When one approached the other, they often interlaced their tails, and it was only after much struggling that they could separate themselves. When they came to the end of a reed, they would hold on even by the lower part of the cheek, or chin. They acted in the same manner when they wanted to rest their bodies, or when they desired to fix their tail upon some new object."

The shark, whose fierce instinct and ferocity are proverbial, may be tamed. Lacépède, in whom we do not put much trust, in spite of his genius, said that sharks become gentle under certain circumstances, and show affections very different from their usual destructive tendencies.

The skate, which we believe is little capable of tenderness, is, however, if we trust Lacépède, susceptible of great attachment, scarcely any being having more fidelity, and none proving more constant in love.

It is said that necessity is the mother of invention; we may learn that it is the mother of intelligence also. There is not a being so barbarous but it may be modified in its habits, and its talent developed, according to circumstances.

An intelligence peculiar to the finny tribe, leads them to select food suitable to the seasons of the year. The most tempting fly presented to a fish, when it is not in season, will be refused; and again, you may offer it at certain hours of the day, when the fish will care but little for it. Say if 
turbots want intelligence, which plough up the sand in furrows, or dig themselves refuges at the bottom of the sea in which to hide themselves from their enemies. Is the eel foolish, which goes out at night from the bottom of the mud and travels over the meadows to surprise the sleeping worms? Do you treat as among simpletons that gilt-head, which lives in the depths of the water, and affects a goodnatured air to entice the little fishes round him without mistrust? At the moment when they are within his reach he stretches forth his extensible snout, and, in an instant, swallows the unwary. Observe, also, the long-beaked banded-fish, or the wary dart-fish, which slily approaches the flies, shoots them with water, and never misses them!

Do you say that fishes have less sensibility than man? It seems true; but take the answer from Sir Walter Scott: "It is a delicate question, and one which fishes alone would be able to solve." Are they less happy than the more intelligent beings? Listen to Virey: "Fishes digest easily, are not affected by variation of temperature, neither by inequality of living, neither from loss by perspiration, from any derangement of body, blood, or humours." Some philosophers assert that fish have not, like man, heartaches which cripple life, disappointments, or passions to torment them; that they are not elated with lively pleasures, or depressed by profound grief; and have as temperate a nature as the medium in which they live. These enthusiastic naturalists urge that the proud repose of the stoic, and the soft luxury of the epicurean, are the fruits of reason, while the quiet joys of the phlegmatic temperament belong to the fishes; that reason is not so sure a barrier against passions as apathy of body; and so aquatic animals will always have the advantage over terrestrial, and live proportionately longer. 


\section{BIRDS.}

MISTAKES ABOUT BIRDS-THEIR BRAINS, SIGHT, HEARING, TASTE, AND SMELL-HOME INSTINCTS-MUSCULAR POWER -RESPIRATION-TEMPERATURE-BIRDS OF PASSAGEBIRDS IN SPRING-THEIR COLOURS-INTELLIGENCE OF THE FEMALE-THEIR HEROISM IN DEFENCE OF THE YOUNG-ENERGY OF THE SPARROW-BIRDS CLASSED ACCORDING TO THEIR INTELLIGENCE-BIRD LANGUAGE -TOOLS OF BIRDS; FEET AND BEAKS.

Wно has not often heard it said of a frivolous and inconsiderate person, "She has the head of a linnet ?"

Popular common sense is sometimes mistaken in its comparisons, but this is essentially just. This charming little bird, with a fine delicate head, manifests, indeed, but little intelligence and reflection. In vain its beauty seeks to atone for its want of sense. Light-headed the linnet is called, light-headed it will remain. But this bird is not the only one which we accuse of want of sense. Our rhetoric makes use of a number of comparisons regarding the winged tribe, which we are only too ready to adopt. We are constantly saying, "stupid as a turkey," "silly as a snipe," "foolish as a buzzard."

We associate such an idea of imbecility with birds, that when we wish to taunt or ridicule each other, we make use of such terms as "goose," \&c.

We lay all our bad passions on these innocent creatures. We call the owl untamable and taciturn; the heron sad 
and melancholy; the gull is insatiable and clamorous; the magpie inquisitive, boasting, and thievish. To hear our language, one would say birds must be essentially a race of degraded creatures. But it is not so. Science, wiser than imagination, has declared that birds have not such little brains as we have been led to suppose.

It has been proved that the brain of the canaries excels, in proportion to the bulk of their bodies, that of man. We know well that, in a general way, the brain of birds is not so voluminous as that of the mammalia; the hemispheres are deficient in circumvolutions, and are not so well developed. And here again we find that the intellectual manifestations are in proportion to the extent of the cerebral organs. The brain of the ostrich is not larger than that of the barn-cock. The goose and turkey have very small brains. But the disproportion of the brain compared with the bulk of the body is most remarkable in the whole order of coast-birds. These are the most savage, and the least susceptible of being tamed. In the order of rapacious birds the cerebral mass sensibly increases, especially amongst the falcons; this increase, however, is most manifest in the night birds of prey, whose heads are very large.

The following is a scale of the size of the brain compared with the bulk of the body, in some birds and mammalia. On examining this list it will be seen that the most intelligent of the larger animals have not so large a brain as we should expect. In truth, it will be found that the degree of intelligence is not always in proportion to the cerebral mass. The brain of the canary is equal in bulk to I-I 4 th of the body; barn-cock, I-25th; sparrow, I-25th; chaffinch, I-27th; robin, I-32nd; blackbird, I-68th; duck, I-256th ; eagle, I-260th; goose, I-360th. In man the brain varies from 
I-22nd of the body to I-32nd; the higher apes, I-3oth; cat, I-94th; the dog, I-I6Ist; the horse, I-40oth; and the elephant, I-50oth.

Few animals have the brain more developed than the parrots. The cerebral mass of the graminivorous and the insectivorous birds is, in proportion to the weight of the body, as great as that of man. It is easily understood, then, that intelligence may not be so rare among birds as some have supposed. They are certainly much superior to many of the insectivora, the kangaroos, the bats, the rodentia, and to most of the ruminants.

We are often greatly at fault when we study animals. We always wish to compare their organisation with ours. We say they are less perfect than we are, because such and such organs are less developed in them than in us; this is a great error. Each creature is perfect with regard to its kind, or the requirements of its state of existence, and often possesses much which another wants. Thus, birds are admirably endowed with the sense of sight. It is supposed that there is a direct correspondence between the extent of vision and the rapidity of flight. The eagle, hawk, vulture, and all the other birds of prey, with the exception of the night birds, survey an horizon much more extensive than man can.

"The martin," said Belon, "perceives a gnat distinctly at the distance of five hundred yards, darts upon it, and carries it off in the twinkling of an eye, with unequalled dexterity. The kite, which hovers in the air, far beyond our sight, easily perceives a dead fish floating on the surface of the water, or the imprudent field-mouse just coming out of its hole."

Birds, surveying with a single glance a considerable 
extent of country, are often obliged to adapt their powers of sight, according to the position in which they find themselves, either on the earth or in the air. Their eyes are naturally long-sighted, except those of the aquatic birds, and the crystalline lens is more flattened than in the mammalia. To enable them to see from a great distance they possess a particular organ, enabling them to give the eye a high telescopic power. The bird's eye is, in fact, a self-adjusting telescope, which can also become a microscope. The bird has a third eyelid, which, acting between the other two, covers the ball of the eye, and moves over it incessantly, to keep it clean and brilliant like an eye-glass; this lid serves also for a curtain against the dazzling rays of light. It is probable that an eye so well organised is admirably adapted to the wants of birds in their periodical voyages to far-off countries. This third eyelid is called the nictating membrane, is semi-transparent, and, when not in use, is neatly folded up in the inner corner of the eye. It is rapidly drawn across the eye by two muscles, and returns to the resting-place by its own elastic action. The telescopic power of the vulture's eye was shown by actual experiment a few years ago. Some naturalists stuffed the dried skin of a deer with hay and left it on a prairie; in a short time a number of black specks were seen far up in the sky; these became larger and larger, and at length were found to be a troop of vultures rapidly descending towards the spot where the stuffed deer lay. The birds at length alighted, approached the skin, and struck their beaks into the leathery substance. After hovering about for some considerable time, apparently in great astonishment, the vultures flew off slowly and sadly. Now it seems clear that, in this case, the birds must have seen the stuffed deer-skin 
from a height in the air at which they were invisible to the human eye. Smell could have had nothing to do with the result.

Next to the sight, hearing appears to be the second sense of birds-that is to say, second in perfection. Hearing is not only more perfect than the smell, taste, and touch of birds, but even more perfect than the hearing of quadrupeds. We see this proved by the readiness with which some birds repeat a long succession of sounds, and even of words. It happened that we took away a nest of sparrows from beneath the roof of a cottage, and placed it on a balcony, before the young were old enough to call for their parents. The father and mother did not, in this case, recognise their nest by sight; but in another experiment, when the little ones were able to call out, the parents distinguished their voices, and brought them food. Here the sense of hearing exceeded that of sight. Many birds are accused of being completely deaf, especially those having large bills. But we all know that such birds possess voices; were they deaf, they would necessarily be dumb. We have seen that there is a correspondence between the sense of seeing and the rapidity of flight; the same harmony also exists between the organs of speech and hearing in all animals, especially birds. The sense of touch also belongs to birds. Buffon says that they have more feeling than quadrupeds, that the sense of touch in their claws is strong, as they continually use them for grasping. Nevertheless, he adds that the inside of a bird's claw being always lined with a hard, callous skin, the touch cannot be very delicate, nor the sensations which it produces acute.

Birds are certainly not creatures of taste. Dame Nature would have it so, and with good reason. If these 
animals, destined to produce an amount of heat superior to ours, had been gifted with delicate palates, they would have been too fastidious for their proper food, and would never have eaten enough to keep up a suitable degree of temperature.

Birds do not masticate, but swallow their food unchewed. This matters little to them, for the horny nature of most of their tongues unfits them for tasting. But many birds show much skill in the use of their wonderfully formed tongues. The humming-bird turns the organ into an admirable pump, by which it sucks up the juices of flowers; and the woodpeckers use their tongues as darts to transfix insects. These birds are compelled to employ a complex machinery of small bones, by which the tongue is lengthened and directed on the prey.

The sense of smelling does not appear to be well developed amongst birds, a great number of them having no nostrils-that is to say, no open tubes on the beak, so that they cannot smell, except by means of the interior cleft in the mouth. Those which are furnished with nostrils enjoy a more highly developed sense of smelling than the others ; nevertheless, the olfactory nerves are proportionally smaller, less numerous, and less extensive than in quadrupeds. Some have been tempted to explain by the sense of smell, certain singular faculties in birds. Indeed, how else can we account, say they, for the marvellous return of the carrier-pigeon, which is taken in a close vessel from its native home to a distance of three hundred miles, across countries quite unknown, and which, as soon as liberated, has no difficulty in returning to its home? How can we explain the fact of a messenger-pigeon, which, being sent from Toulouse in a covered basket, when set at liberty, knew 
perfectly well how to return to the place of its departure? Is it to one of the senses, or to a peculiar intelligence that we must attribute this faculty? Assuredly it is not due to hearing, to touch, nor to taste. Is it due to the sense of sight or smelling? There may be doubts as to the pigeon shut up in the basket, but as to the one which was carried in a close vase, it is evident that the poor winged animal, had it the scent of a dog, would never have been able to return direct home by the aid of its nose. The phenomena cannot be otherwise explained than by the general sensibility of the bird. Launched in the atmosphere, it follows the direction of its sensations, and knows what route must

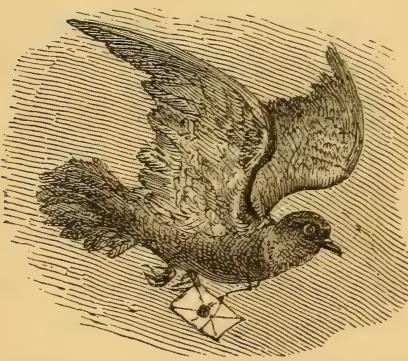

The Carrier Pigeon flying straight for home.

be taken to reach the north or the south. Its sensibility serves for a compass, and also for a thermometer.

A carrier-pigeon taken out by the Arctic discoverer, Sir John Ross, in 1850 , from its dovecot in Scotland, was let loose at Wellington Sound, within the Arctic circle, on October 6th, and reached its former home in Ayrshire in seven days, having flown two thousand miles across the Atlantic. No one will venture to assert that the pigeon could see its distant dovecot through two thousand miles of atmosphere. Such marvellous feats performed by birds cannot be explained by " our philosophy."

Toussenel cites an example of a goldfinch that every week quitted its native town, situated in Picardy, for Paris, carrying a notice to prepare its master's apartments. 
With a large brain birds could not hover lightly and easily in the air. It could not be expected, then, that this organ should have the same development as the organs of locomotion. What a bird requires is moving power; and for this it is beautifully adapted, by its muscular and nervous system.

By the aid of the microscope anatomists have discovered in the brain and marrow many kinds of little cells. Some affect the functions of sensibility, others of motion; the latter being complex and much larger than the others, and serving especially for muscular contraction. We observe, then, that these are, in proportion, more numerous in the bird than in other vertebrated animals, and this is evidently the cause of their rapid locomotion. The bird may lose in intelligence what it gains in motive power; but its destiny is to fly, and therefore it has wings and high muscular energy-

" Wings! to bear me over

Mountain and vale away;

Wings to soar above the sea

In morning's sunny ray."

"Nature," said Buffon, "in giving wings to birds, has bestowed upon them the attributes of independence and the means of perfect liberty. Thus no other home but the sky is suitable to them. They foresee the vicissitudes and changes of climate, in anticipating the seasons ; they do not settle in any place till they have assured themselves of the temperature. Most arrive only when the soft breath of spring has clothed the forests with verdure; when it has drawn forth the fruits necessary for their nourishment; when they can settle, take shelter, and conceal themselves in the shade; and when, Nature developing the power of love, 
heaven and earth seem to combine for their pleasure and happiness."

As nothing is imperfect in the formation of a living creature, everything being adapted to its condition and the end it has to attain, so the structure of a bird presents a light

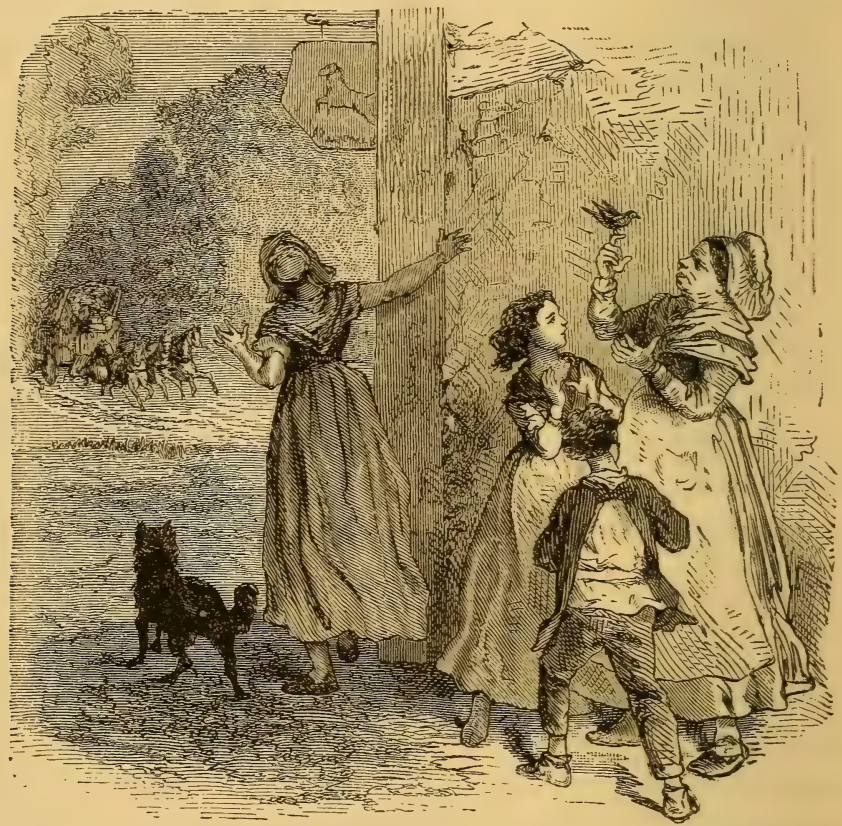

The Goldfinch giving notice of his Master's arrival.

frame. Destined to live in the air, it must have less weight than the fish which is supported in the water, or the mammalia which mostly pass their lives on the land. All has been so wonderfully foreseen and calculated, that, as the birds advance in age, gaining form and bulk, the bones become lighter and more cell-like, enabling them to take 
more air into the interior, so that the atmosphere, which is the element most essential to the bird, penetrates nearly every part of its body, and enables the creature, above all others, to inhale the most oxygen. Microscopic investigations have demonstrated that the cells in the bones of some birds measure but $1-5000$ th of an inch in diameter. The tubes in the bones, called the Haversian canals, from their discoverer, Mr. Clapton Havers, are also both numerous and minute. We know that in the mammalia there is between the pulmonary and abdominal regions a division called the diaphragm; this division limits, in some degree, the expansion of the lungs. In birds, on the contrary, the membrane is open, porous, and small, affording a free passage to the inhaled air. This air, penetrating into all the cavities, fills the little cells, which, pressed by the muscles, perform the office of bellows, and promote the work of respiration. It results from this peculiar structure, that the blood, thus heated and rendered more fluid and exciting by the oxygen, gives to the movements of birds that quickness of action, that joyous impetuosity and lightness which charm us. This supply of air also enables them to extend the vibrations of the voice. This air carries life, health, and activity into the feathers, and thus these inhabitants of the atmosphere lose much of their relative weight. It is not, however, true that all birds thus diminish the weight of their bodies by filling the cavities of the bones with air. Dr. Crisp examined many skeletons in order to ascertain the truth in tinis matter, and found that, out of fifty-two species of British birds, only one was so formed as to admit air into its bones. This was the sparrow-hawk. Many of those which had no air-cells were birds of rapid flight. The skill and energy with which the bird strikes the air with its wings, and the 
peculiar angle at which these act, have more influence on power of flight than the air-cell. Few birds can justly be called "feathered balloons," as some naturalists have ven. tured to write. The condor of the Andes is able to support its vast body at the height of 20,000 feet above the sea, where the atmosphere is so rarefied that the barometer falls to fourteen inches.

This abundant supply of oxygen gives to birds a degree of heat which manifests itself in all their actions. The temperature of man does not go beyond $98^{\circ}$; in some birds it rises to $107^{\circ}$. Add to this elevation of temperature a heart provided, like man's, with four cavities, and you will be able to understand how the bird glows with the fire of life; how it can face the most severe winters; how, by aid of the air, which penetrates, warms, and dilates the organs, the bird can become lighter when occasion requires. The feathers, also, so well fitted to preserve this heat, assist in raising the creature to the higher regions, where the tyranny of man cannot reach. This warmer blood of birds renders them more sensitive, lively, and ardent. They seem always agitated, excited, and restless, sleeping but little. They have also the faults of this temperament, being fickle, inconstant, irascible, impetuous, and unreflecting. Their lively impressions want depth; they feel rather than think. To instruct them it is necessary to isolate them, to deprive them of light, and keep them in a cage. The loss of their liberty is the only means by which they can be made to reflect. It is also necessary to choose the evening for teaching them. At this hour they are not excited by the light; the shades of night oblige them to be quiet; they are more attentive and better able to retain the air or words we wish them to repeat. 
Bird-catchers, and those who sell birds, sometimes destroy the eyes of nightingales and other singing-birds to improve their voices. It appears that these poor little creatures, deprived of sight, utter most melodious and touching sounds-for which reason some persons compare them to Homer and Milton. The singing of birds! Is it not a convincing proof of their intelligence? We hear a sparrow, a lark, a nightingale, a tomtit-we distinguish them easily, and recognise each by the modulations of the voice. Perhaps you will say that they sing thus naturally and instinctively, that they have never been taught and do not know what they say, and that there is nothing of feeling or intelligence in these vocal manifestations. Let us remark, first of all, that in every species each individual seems to make himself understood by the others. Every sound of the voice has a particular signification, which serves as a means of communication. If it were otherwise, how could those that live in companies under stand one another? How could they construct those nests which are so complicated and so artistically arranged? How, in these works of architecture, would each have his task? All work in common necessitates a mutual understanding.

Let us now speak of the birds of passage. When they are about to pass from one climate to another, do they not assemble together? To hear them, one would say it was a legislative assembly, where each speaks in turn, giving his opinion and his advice in the decision which is to be taken. During the journey, the emigrants, according to their authority or rank in the assembly, continue to make themselves heard, regulating the swiftness of the flight, so that those more feeble can follow the stronger, and recalling the wanderers. 
Birds manifest most feeling, sentiment, and poetry in their language during the spring-time of life. Is it not the power of love-that sublime exaltation of the heart, that strong impulse of our being-which renders the most feeble strong, the most simple intel-

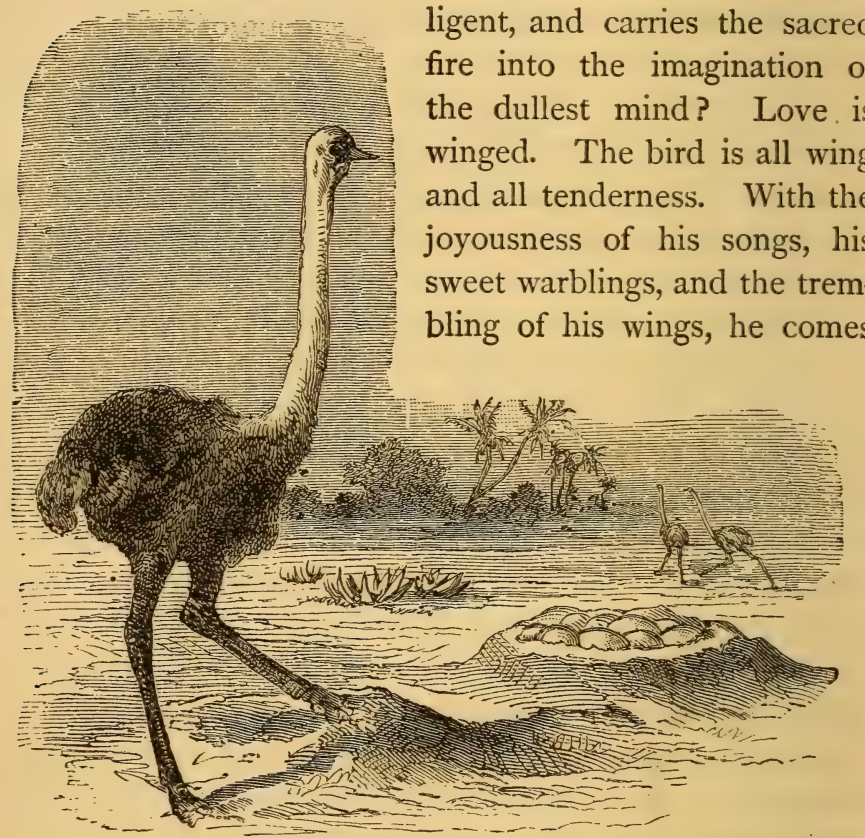

The Ostrich burying her Eggs in the Sand.

to reproach us with our falsehood, our coldness, our mean selfishness, our miserable calculations, and our broken faith. He enters our dwellings, establishes himself in our gardens, instals himself under our roofs, to repeat to us, from morning till evening, "Love, love, love; you must love 
each other; you must always love each other." But we have neither the intelligence nor strength of feeling to love each other as we ought.

It is also in the spring that birds have their most beautiful dress and their brightest colours.

Reviving Nature gives to animals festive dresses; to the mammalia a more silky coat; to the reptiles scales of a more brilliant hue; to the birds most beautiful feathers. She nourishes the insect in the larva state, and reproduces it in the form of a gay butterfly, so that it is not only the corolla of plants that displays brilliant and variegated colours.

The female, among birds, surpasses in intelligence the females of other animals. She is more considerate, more reflecting, and more provident. She chooses the situation for the nest, and knows how to modify it according to necessity and climate. The female ostrich buries in the funnel of sand, where the little ones are to be hatched a certain number of eggs for their first nourishment.

In the Levant, a tomtit sewed together, with the aid of her beak and some thread, two leaves of a shrub, and established her family in this pocket of her own invention. All the perfections of a nest seem due to the intelligence of the female; the males being only admitted into this important construction as workmen. With certain birds, who live in pairs, a few of the males join in the task of incubation, as among the wood-pigeons, turtle-doves, and storks. 'Those who have not seen, says Toussenel, the turkey hen, the partridge, or duck defend their little ones, can have but a moderate idea of their heroism. A man who should display but once In the course of his career, as a citizen and patriot, a tenth part of the devotion that these poor 
creatures manifest continually, to secure the safety of a successful hatching, would have places of honour during his life, and statues after his death. A partridge who trails her wing, and pretends to be wounded in sight of the dog, and flies in his face to tear

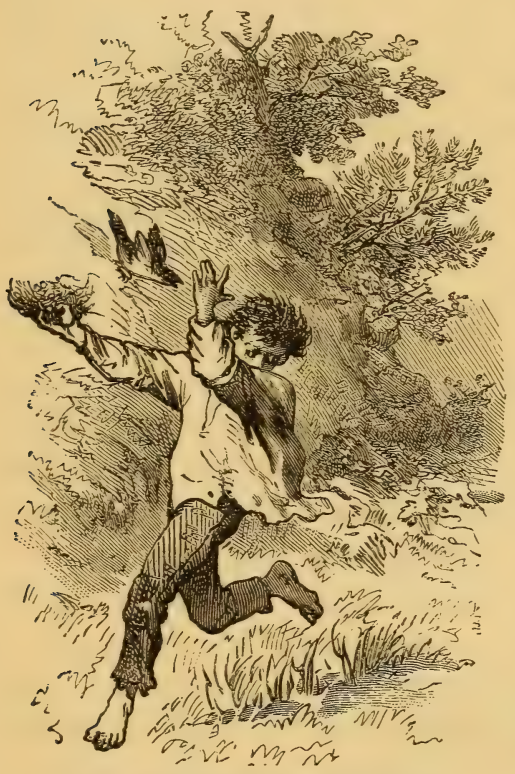

The Magpie defending her Nest. out his eyes; a magpie who puts to flight, by the violence of her resistance, the young spoiler of her nest; the swan which will not allow a party to drink of the water belonging to her little ones-all these poor mothers, whose existence is but a long series of heroic acts and devotion, would scarcely understand our admiration for the Athenian Codrus, or the Roman Curtius! The tree sparrow (Accentor modularis), you say, is unbearable with always the same note; it is not a song at all, only a chirp. But, listen to him in the spring! The joyous bridegroom sings like a master. Love has made him a poet; it is no longer the careless pupil, álways repeating the same note; it is a musician, who attempts the most difficult passages. $\mathrm{He}$ gives his "do, re, mi," from the chest. He knows that to persuade he must be eloquent. He becomes so. 
No sooner is the common house sparrow occupied in constructing the nest, than a new sentiment manifests itself in him-the love of offspring. He must think of providing a shelter for his little ones. This occupation makes even this sparrow a little thoughtful, but, no sooner has he picked up the first blade of straw than he is filled with joy. $\mathrm{He}$ returns a hundred times a day, carrying building material in his beak; he chirps, as if he were pleased with himself, flies back again, returns to the meadows, goes, comes, and so on all day long, looking, without appearing to do so, to see if any one is at the window, or if there are enemies behind the curtain. The sparrow is better able to see you than you are to conceal yourself. Beneath the roof of our cottage were ten sparrows' nests, certainly not masterpieces; the work was rough, the materials common, and the dimensions absurd. These nests are like sign-boards; one would imagine the birds wished us to be deemed strawmerchants. But what signifies? We would not prevent them building their nests on the house, but, as we were not in the habit of wearing helmets, we feared the misfortune that befel Tobias. For you know the sparrow is not very cleanly. "He is also," says Toussenel, "quarrelsome, a chatterer, tippler, jeerer, plunderer, babbler, impudent, familiar, riotous, and obstinate. Finally, he is driven, by incessant want to scorn the authority of and mystify the landlord. One bird was untidy enough to soil my sleeve with a piece of mortar he had detached from the eaves. I immediately sent for a joiner, telling him to cover every hole with boards, and employ all his ingenuity to prevent the smallest sparrow from penetrating any of the crevices to build his nest. The joiner worked all day against these volatile anarchists. Three days after the birds, by exploring the roof, 
by examining and watching, and by striking the planks with their beaks, had defeated the skill and precaution of my joiner. Then I sent for a mason, and begged him to stop up the smallest holes with plaster. I afterwards watched attentively myself, determined not to be played with again by those rogues of sparrows.

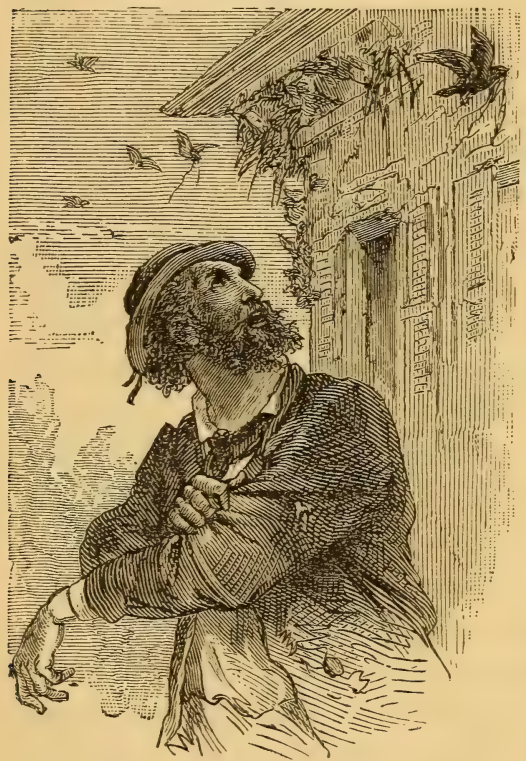

The Bird detaching a piece of the Mortar.

I was soon convinced that it was impossible to baffle their skill when determined on nestbuilding. Two sparrows, more clear-sighted than the rest, in spite of all the precautions I had taken, and notwithstanding my constant presence at the window, were able to find a place for nests. They succeeded so well in penetrating the boards, that my own contrivance had enabled them to construct a snug dwelling, well-sheltered from the weather, and far out of my reach. I acknowledged myself completely vanquished, and left them in peace. I was, however, recompensed for my forbearance, by being witness of a very touching scene. When the little ones were able to come out of the nest, being perched up so high, one of them tumbled on to the balcony and hurt itself, so that it could not fly. 
"Then all the sparrows, from the neighbouring trees and hedge, from the oldest to the youngest, came on to the balcony, bringing to the poor little fellow, in their bills, the tenderest consolation. The young ones came while I was present, the old ones, more experienced and crafty, knew perfectly well at what time in the day I was absent, and did not fail to come and counsel the poor disabled bird. This lasted three days and nights, during which my sparrow retired on a chair to the corner of the balcony, slept peaceably, having at his side two other large jolly fellows, to serve as sentinels. On the fourth day the little wounded one departed, joyous as a boy returning from school."

Lacépède believed he could determine the amount of sensibility in birds by their constancy, and the great care they bestow upon the females and little ones, and he proposes the following distinctions, beginning with the lowest degree in the scale.

ist Class.-Birds whose males forsake the females before they are occupied in preparing the nest.

and Class.-'Those which leave the females while they are occupied in preparing the nest.

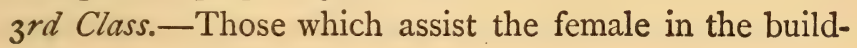
ing of the nest.

$4^{\text {th }}$ Class.-Those which guard and protect the females during incubation, bringing them food, and singing beside the nest.

5th Class.-Those which assist the females in the incubation.

6th Class.-Those which take part with the female in rearing her young.

7th Class.-Those that prepare, in their crops, the food for their little ones. 
8th Class. - Those which live with their young, helping and defending them until able to take care of themselves.

He estimated also the amount of industry, according to the greater or less degree of perfection to which birds attain in the building of their nests. These last qualities, added to the degrees of sensibility, serve to distinguish the superior birds, which are thus classed :-

rst Class.-Birds which do not build nests, but take possession of another's.

2nd Class.-Those which compose their nests of rude materials, and join them without care.

$3^{r d}$ Class.-Those whose nests are formed with materials chosen after examination, prepared with care, and brought from afar.

$4^{\text {th }}$ Class. - Those which build nests with materials twined and woven together, with marvellous skill.

$5^{\text {th }}$ Class.-Those showing particular research, attention, and discernment, in placing their nests in the most convenient position at the extremity of a branch, or under the leaves, to preserve their little ones from danger.

6th Class.-Those whose nests have a narrow entrance, an awning, winding entrances, and several compartments.

$7_{\text {th }}$ Class.-Those which join with other couples, and build their nests in close proximity, to receive several families.

8th Class.-Lastly, those which form a numerous society, whose nests are covered with a common covering, due to a combination of good-will, resource, and skill.

To establish a fair comparison between the species noted for industry and sensibility, we must observe the results of those two faculties in reference to the changes of climate, 
the elevation of the temperature during hatching, the solitude of the nest, the number of enemies, the power of defence, the swiftness of flight, and the form of the beak and claws, as instruments with which the bird can gather, prepare, and arrange the materials for the nest.

For the brain to act vigorously, the blood, which stimulates and vivifies it, must be pure, and have a certain elevation of temperature and activity of circulation. Birds have these qualifications, and this is the reason that, notwithstanding the smallness of their brains in general, they are susceptible of great feeling, and have, at the same time, real intelligence. A creature with warm blood usually possesses a generous heart, is active and intelligent.

Eloquence amongst men is often mixed with vanity, or a desire to appear clever, a wish to persuade, that they may rule and sometimes tyrannise over others. With birds, eloquence is a sign of tenderness and affection. I approach a nest, the mother flies away, raising cries of distress; she alights on some neighbouring tree and sings at the highest pitch of her voice, to draw my attention and attract me towards herself, that I may leave the path near her family. I take one of her little ones; the song changes, the sound is more melancholy, and the sentiment of sadness is conveyed by a different language.

Birds possess a common language; but when they are in love they must express their passion, and even add rhythm and intonation. They are poets of all kinds! Some adopt the trivial style, their songs are short but noisy. In this manner crows the cock on the dunghill, in the midst of the hens. The chaffinch has a more elevated poetry. The lark while soaring in the air, sings a hymn on the beauties 
of nature. The nightingale overcomes the greatest diffi. culties both in poetry and singing.

Dupont was asked how one could learn the languages of animals, and from it form an idea of their feelings. He replied that the first step towards success was to carefully observe the animals, and remark if the sounds uttered seemed to have a meaning amongst themselves.

When we live familiarly with animals, if they are the least susceptible, it is impossible not to be convinced that they have a language. There is passion in the song of birds, but it is combined with intelligence. Toussenel, who occupied himself with much perseverance and success in noting the expression of emotion, proves that the most intelligent birds are those which sing best, and whose sojourn is near to man. "Song," said he, "the perfume of the soul, and privileged language of tender hearts, not only suggests the past, but is also the special joy of the present hour. The song of birds carries praise from earth to heaven, acknowledges the goodness of the Creator, and is gratitude poured forth in melody."

The vulgar make a great mistake in thinking the female has no voice. In her infancy she has, like her brothers, gone through a course of vocal music, and she must have a certain knowledge of music to enjoy the charming songs that are sung to her day by day. The females express themselves perfectly in passionate language, when the fancy takes them, or when they are condemned to solitude.

Everybody has had the opportunity of seeing, in some liumble dwelling, a poor little canary which tries to pass the weary hours away by singing, but very quickly gives up this sad employment of her time when she becomes the mother of a family. So, a young lady devoted to the piano before 
her marriage, often neglects it afterwards. As the male excels the female in strength, vigour, and brightness of plumage, it is natural that she should be much superior in grace and intelligence, distinguished by a more slender and delicate form, finer sinews, and more flexible beak and claws ; and to her, also, nature has given the charge of the most artistic and nost important domestic functions, which comprehend the building of the nest and the education of the family.

Johnson, in an article in his "Idler," said: "Many naturalists believe that animals, regarded as dumb by the uneducated, have the faculty of communicating their ideas one to another. That they express general sensations is quite certain. Each being who can make any sound, has a different voice for pleasure or for pain. The hound warns his companions when he scents the game; the hen, by her clucking, calls her young chickens around her for their food, and recalls them from danger by her cries." Birds possess the greatest variety of notes. This truth would certainly be sufficient on which to compose a discourse, if we wished to do so. Superstition or curiosity has always shown itself attentive to the cries of birds, as well as to their flight. Many men have studied the language of the feathered tribes, and some boast of understanding it. Naturalists have disputed whether the peculiar song of each kind of bird was an innate gift or an acquired faculty. Dr. Gall, a distinguished observer, is said to have taken a nightingale and isolated it from its companions. " The bird," said he, "did not sing the less on that account, and knew the scale of notes peculiar to his family." This bird, then, must have had his music in himself. Some facts, however, seem to contradict this. Barrington took from a nest a common 
sparrow already fledged. He put it to school, if one may use the expression, with a singing-master, who was a linnet. The sparrow profited by the lessons of his teacher; but, by chance, the pupil heard a goldfinch, and his song soon became a mixture of the sounds of the two birds. This same experimenter put a robin under the tuition of a nightingale, the latter, however, soon lost its voice, and became perfectly mute in less than a fortnight. Nevertheless, the young robin sang three out of four parts in the tune of the nightingale, and the rest of his song was what bird-fanciers call unconnected-that is to say, in no fixed key. These experiments are very interesting, because they prove that all beings have a language peculiar to their organisation; a language of instinct, and also an acquired language, connected with their education and intelligence. The mistake that some make in studying the song of birds is, that they expect to find in their vocal expression an echo of human ideas and sentiments. The song of birds is certainly a language; but it is a language peculiar to themselves, which corresponds with their organisation, their habits, and mode of life.

The Tools of the Birds.-An excellent implement, which varies with the different orders of animals, serves as a tool for the brain. In man it is the hand. This organ, of such marvellous construction, is evidently designed to serve the finest thought and the most elevated intellect. By means of this, man can weigh, measure, design, translate his thoughts, and give to his conceptions a form as readily as he can express his ideas by words. This hand, which characterises so well the superior intellect of man, differs from the paw, which is the corresponding organ in beasts, by the position of the thumb and the other fingers. The 
power of seizing, which is the beginning of manual skill, implies the opposition of the thumb with the fingers.

The foot of the bird is the best instrument of its intellect, and the more perfect this member is, the more it approaches the hand of man, and indicates a developed brain and intellect in the bird.

Thus the foot of a water-fowl, which is the least intelligent of the winged animals, is most unlike the hand of a man. The thumb, when there is one, has a direct position like the fingers; it thus has a tendency to separate from the fingers instead of joining them. The foot of the waterfowl is not adapted for grasping; very few species of this order can perch. With the marsh birds the power of grasping becomes less rare; one, indeed, is endowed with the ability of seizing, like the parrot and birds of prey. Others use their feet as weapons, like the game cock and the emu of Australia, which is said to be able to break a man's leg by a blow with its foot. However, the direct plan of thumb and finger is the general rule for web-footed and stilted birds. With birds of the poultry kind, or gallinaceous order, the rule is not the same. About three-fourths of those are able to perch, an act which implies that of grasping, and also of opposition between the front and back part of the foot; those birds use this power only to seek a refuge from their enemies, and to roost for the night.

Some of the species use their feet for striking, and many for scratching the soil ; as, for instance, the hen, and all of that family. There are some that do more, even raising little hillocks of earth by the strength of their feet. Others collect grass and heap it together to make places for hatching, thus considerably extending the functions of their claws. Nor must we forget the powerful tools provided in the 
diversified beaks of birds. The wide opening bill acts as a net to catch insects; the suctorial beak of the sun bird is a pump; the finches and crows have a pick-axe and berrycracker in their cone-shaped bills; those of the butcher birds form tenacious gripping machines; and the beak of the parrot is a hand.

Thus the skilful use of the beak and foot, and the near approach of the latter to a hand, show the degree of intelligence in birds. The parrot is the most intelligent of the flying birds, and possesses in the foot a superior hand, like that of the monkey, or of man-a hand which conveys food to the mouth. The clever author of the "World of Birds" asserts that the intelligence of the parrot is in direct connection with the perfection of its foot. "The faculties of the parrot," says he, "are in proportion to its manual skill. The capacity of the brain is greater than in any other bird. The beak, which answers the purpose of a third hand, and of which the two mandibles are movable, is the most perfect of all the organs of this kind. Its propensity to imitate man and speak his language, its prodigious memory, aptitude for learning, taste for fruits, and longevity, make its superiority undeniable." Let us, then, commence the particular study of the intelligence of birds, with the parrot. 


\section{THE PARROT.}

THE intelligence of the parrot is misunderstood. According to vulgar prejudice this bird is nothing better than a chatterer, a senseless creature, an animal without an idea of its own, and destitute of all judgment. Nevertheless, the parrots occupy among the birds the rank which quadrumana hold in the class of mammalia. The brain is more developed than in other feathered creatures, and, as we have already shown, we find in them intellectual manifestations. Buffon, who so unwillingly admits intelligence in animals, has, in his chapter on parrots, discoursed at some length on the question of their intellectual faculties. "These birds," he says, "which have every facility for talking, are deficient in that intelligence which aids the high faculty of language. They are deprived of this, like all other animals, by their rapid development in early life, and by the short duration of their intercourse with their parents, whose cares are limited to their bodily education, and are not continued long enough to produce any durable or reciprocal impressions, or to establish family union, the first element of all society, and one great source of all intelligence." It is certain that all social relations assist the development of intellect; but, above all, to become intelligent it is necessary to have a well-organised brain, and we must not expect in creatures, whose cerebral organs differ from ours, intellectual manifestations equal to our own. Again, although animals have not the same intelligence as we have, yet some organs are 
more perfect than ours; they are not, then, so very unlike us; and we, like them, are animals.

Buffon s?ys that the faculty of imitating our speech and gestures does not give any pre-eminence to animals which are endowed with this natural talent. According to Buffon, the monkey which gesticulates, and the parrot which repeats our words, are not capable of becoming more intelligent, and of improving their species. This talent, indeed, serves to render the parrot more interesting, but does not give him any superiority over other birds, excepting that, possessing more than others the power of imitating speech, he must have the sense of hearing and the organs of the voice more like those of man. This power, which the parrot eminently possesses, is found in some degree in many other birds whose tongues are thick, round, and almost the same in form as that of the parrot. Starlings, blackbirds, jays, and jackdaws can imitate natural sounds. Those which have the tongue forked, like most of our small birds, whistle more easily than they chatter. Those in whom this natural organization for whistling is united with an acute sense of hearing and strong memory, learn easily to repeat airs and whistle musically. The canary, linnet, siskin, and bullinch seem to be musicians by nature.

If any animal, the parrot for example, has the brain and senses more developed than other creatures, it will be more intelligent than other animals, and the intelligence will be susceptible of some improvement, according to the education it receives, and the passions which are more or less called into play. Beings which have the faculties of feeling, of remembering their sensations, of expressing them in a - language more or less developed, but always in harmony with their joys, sorrows, anger, or passion, must they not be 
intelligent? Buffon says, "The parrot, either from a defect in his organs, or from a want of memory, can only utter cries or short phrases, and can neither sing nor repeat modulated sounds. Nevertheless, it imitates all the noises it hears, the mewing of cats, the barking of dogs, and the cries of birds, as easily as it counterfeits speech. It can articulate sounds, but cannot modulate or sustain them by cadences. This proves that it has less memory, less flexibility of the organs, and a throat as dry and rough as that of the singing birds is soft and tender." The parrot, however, is not deficient in memory; it recollects the voices of many animals, and counterfeits them. The parrot, not having a brain so fully developed as that of man, does not possess our intellectual faculties, much less our language; but he has his own, which agrees perfectly with his organization. Buffon adds, "We must distinguish between two sorts of imitation-the one reflective, the other mechanical, and without intention; the former is acquired, the latter, so to speak, is innate. This is but the result of common instinct, by which all seem to be induced or constrained to do the same thing. The more stupid animals are the more perfect in this imitation. A sheep always does, and ever will do, only what is done by the other sheep; the last cell of a bee exactly resembles the first. The entire species has no more sense than a single individual, and in this consists the difference between intellect and instinct. Natural imitation is, in every species, but the result of a blind necessity." Undoubtedly, every being in each species having a like organization, is driven by this organization to similar manifestations; but what is not less certain is the fact that with birds, as in every other kind of animals, there are some which have a superior organization and more in- 
telligence. It is this which enables the bees to modify the arrangements of their cells according to their necessities.

Acquired imitation, according to Buffon, does not extend to the species, nor can it be communicated to them; it belongs only to the individual who receives and possesses, without the power to impart.

The best instructed parrot could not transmit the talent of speech to its young ones. All imitative power communicated to animals by art, or by the care of man, rests with the individuals, and although this imitation may be entirely dependent on the organisation, it supposes the existence of some peculiar intelligence, sensibility, attention, and memory. Animals capable of this power of imitation, of receiving lasting impressions, and some education on the part of man, are distinguished in the orders of organised beings. If this education is easily imparted by man to every individual of the kind, as the dog for instance, the species really becomes superior to that of other animals, so long as its relationship with man continues. The dog, left to its own nature, falls back to the level of the fox or wolf, and cannot of itself rise.

It is with animals as with man, acquired talent cannot be transmitted. It is organisation and mental aptitudes which may be inherited.

A father, naturally clever as a mathematician, teaches his son mathematics; the latter does not transmit the science to his son unless the child has a disposition for this study and a favourable structure of the organs. We are convinced that the talent of imitation acquired by animals cannot be transmitted, although it may draw out certain dispositions.

The talent for mimicry acquired by some animals 
proves them to possess faculties which seem allied to intelligence.

Montbard said that, in the scale of living beings, birds should be placed in the first rank after man. Nature has collected and concentrated in the small compass of their bodies more power than she has imparted to the great mass of stronger animals. She has given them more lightness, without lessening at all the solidity of their organisation. She has ceded to them an empire which extends over the earth, the air, and the water. She has endowed them with exclusive power over the whole race of insects, which seem to exist chiefly to maintain and strengthen their destroyers, by serving them for food. They even rule over the reptiles, of which they rid the earth, without dreading their venom; over the fishes, which they drag from their element to devour; even over some quadrupeds, which are equally their victims. We have seen the buzzard attack the fox; the hawk seize the gazelle; the eagle carry off the sheep, attack the dog, as well as the hare, put them to death, and carry them off to his eyrie. If we add to this pre-eminence of power and quickness in birds other faculties which approach to man's nature, such as imitation of speech and musical memory, we shall see that they approach nearer to us than their exterior form seems to indicate, while the sole privilege of the attribute of wings, and the pre-eminence of flight over running, gives them a superiority over all the terrestrial animals.

We will proceed to show this by facts 


\section{THE COCKATOOS.}

The largest parrots of the Old Continent are cockatoos. These parrots learn to speak with difficulty. There are some, indeed, which never talk at all, except, perhaps, to

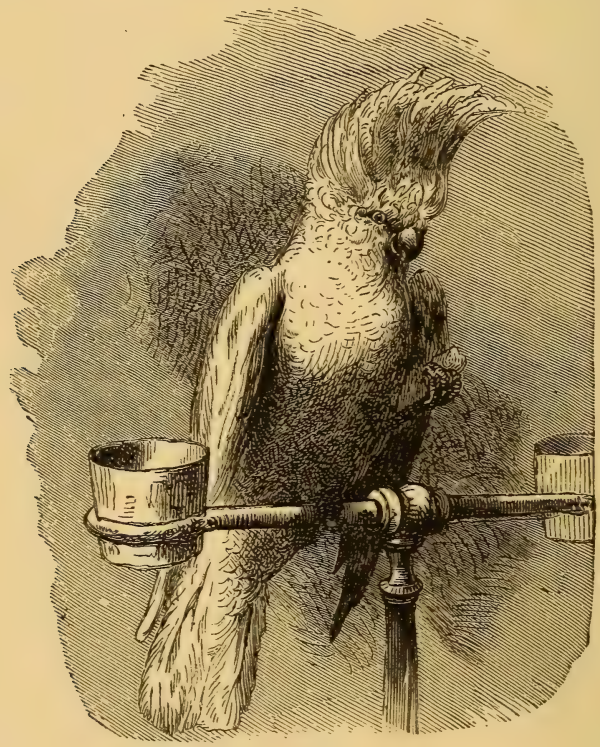

The Cockatoo.

cry out "cockatoo," from which sound they are named. But do not think that those which chatter most are the most intelligent. Cockatoos apply themselves very readily to education, and are easily tamed. They have, it appears, 
become domesticated in some parts of India, where they make their nests on the roofs of the houses. This facility of education, according to Buffon, arises from the superiority of their intelligence. They listen, hear, and obey better than other parrots, but in vain they attempt to repeat what is said to them. They make up for this defect by peculiar expressions of sentiment and affectionate caresses, having in all their movements a sweetness and grace, which add still more to their beauty. Buffon relates that in the month of March, 1775 , he saw at the fair of St. Germain, two cockatoos, male and female, which obeyed with much docility, either by displaying their crests, saluting persons by an inclination of the head, touching objects with their beak or tongue, or replying to the questions of their master, with a sign of assent, which expressed perfectly a mute affirmation. They showed, also, by reiterated signs, the number of persons who were in the room, the hour of the day, and the colours of dresses. These parrots are easily distinguished from others by their white plumage, by the beak being more hooked and rounded, and especially by a crest of long feathers with which their heads are adorned, and which they raise or lower at pleasure. 


\section{JACKO,}

\section{(THE GREY PARROT.)}

The kind of parrot most frequently brought into Europe is the grey or ash-coloured. It is preferred as much for the gentleness of its disposition as for its talent and docility. It is often called Jacko because it usually pronounces that name. The whole of its body is of a beautiful pearly, slatecoloured grey, darker on the shoulders and lighter on the body, becoming whiter at the belly; a tail of vermillion terminates and relieves this glossy plumage, which has the appearance of having been watered and powdered with white, rendering it always fresh. The eyes are surrounded by a naked, powdery, white skin, which covers the cheek. The beak is black, the feet grey, and the iris of a golden colour. The length entire of the bird is one foot.

The greater number of these parrots are brought to us from the coast of Guinea, from the interior of that part of Africa, and from Congo. They are easily taught to speak, and seem to prefer imitating the voices of children, and on that account more easily receive their education from them. It was remarked by the ancients that all birds capable of imitating the human voice, listen more willingly to the words of children, and render them more easily because they are less strongly articulated, and by their ciear sounds 
are more analogous to the power of the bird's vocal organs. Nevertheless, this grey parrot imitates the grave tones of an adult voice; but this imitation seems somewhat difficult, and the words which it pronounces in this voice are less distinct. One of these parrots from Guinea, instructed on the voyage by an old sailor, had caught up his hoarse voice and cough most perfectly. Although the bird was afterwards given to a young lady, and only heard her voice, he did not forget the lessons of his first master; and it was most amusing to hear him pass from a soft, pleasant voice, to his hoarse and sailor-like tone.

Not only has this bird the power of imitating the human voice, but he seems to wish to do so. This is shown by his attention in listening, and by the efforts he makes to repeat every word. He will continue chattering without intermission a few syllables just heard, and tries to drown all voices by raising his own. We are often surprised at hearing him repeat words or sounds that no one has taken the trouble to teach him, and did not even suppose he had listened to. For instance, there is the parrot of Henry VIII., of which Aldrovand relates the story that, having fallen into the Thamse, he called to his aid the boatmen, as he had heard passengers call them from the shore. The Jacko appears to set himself a task, and tries to remember his lesson each day; he is occupied with it even during sleep, and Margrave says that the bird even chatters in his dreams. It is in his earlier years that the parrot shows this power, has most memory, and is found most intelligent and docile. Sometimes this power of memory, when cul tivated early, becomes extraordinary. The parrot which a cardinal bought for a hundred crowns of gold, could, it is said, repeat correctly the Apostles' Creed. 
According to Buffon, Jacko, on awaking, becomes rebellious, and learns with difficulty. Olina advises that the hour after the parrots' evening repast should be chosen to give them their lesson; because, being then more satisfied, they become more docile and attentive.

The education of a parrot has been compared to that of a child; there would often be more sense, adds Buffon, in comparing the education of the child to that of the parrot.

Another very interesting question brought forward on the subject of the parrot is, whether he can hear himself speak? Buffon's sister, Madame Nadault, in a letter written to her brother, affirms her belief that her parrot when he spoke did not recognise the voice as his own, but believed that it was some one else speaking to him, and acted accordingly. He had frequently been heard to ask himself for his own claw, and never missed answering his question by holding it out. Although very fond of the sound of children's voices, he showed great hatred to the children themselves. He would chase them, and if he caught them, pinch them till the blood flowed. As he had objects of aversion, he had also others of great attachment; his taste, indeed, was not very fastidious, but it was persistent. He loved the kitchen-maid most desperately; followed her everywhere; sought her in the places where she was most likely to be, and seldom in vain. If he had not seen her for some time, he would climb on to her shoulder by aid of his beak and claws, load her with caresses, and would not again leave her, notwithstanding her efforts to get rid of him. If at last she succeeded in disengaging herself, he was after her again in an instant. His attachment had all the marks of a most heartfelt friendship. This girl had a very 
bad finger for some time, which was so painful as to cause her to cry out frequently. All the time she was suffering the parrot would not leave her room, and showed his sympathy by groaning himself as piteously as if he also were suffering. Every day his first walk was to pay her a visit. His tender interest in her continued as long as she remained ill. As soon as she was better, he became easy ; but showed the same affection, which never changed. However, his excessive liking for this girl seemed to be caused by something in her work in the kitchen, rather than her person; for, having been replaced by another, the affection of the parrot only changed its object, and seemed to be as great for this new kitchen-maid, even from the first day; a proof that her care and attention had not procured this attachment.

We regret to record this latter trait; but if it prove a want of fealty in Jacko, it does not affect his intelligence. He was a clever flatterer, and knew well what could be obtained from the servants by caresses. Who will dare to say that Jacko was an imbecile? The talent of this species of parrot, says Buffon, is not confined to imitation of speech; they learn also to mimic certain gestures and movements. Scaliger had seen one which imitated the dance of the Savoyards while singing their song. He loved to hear singing, and when he saw dancing, jumped about also but with the worst grace in the world, holding his claws inwards, and falling back heavily. This was his greatest delight. Jacko has also been seen exhibiting foolish mirth; chattering incessantly when tipsy, for all parrots love wine, particularly sherry and muscadel.

Buffon, after having acknowledged the intelligence of the parrot, says, "This burlesque of a language, without 
ideas, is certainly very odd and grotesque; and, without being more empty than many other discourses, is always more amusing." He relates the anecdote borrowed from Clusius by Willoughby. It appears that a parrot, when they said to it, "Laugh, Polly, laugh," laughed immediately in good earnest, and the next moment called out, "Oh! the great fool, to make me laugh." Another, which had grown old with his master, and shared with him the infirmities of age, being accustomed to hear but little more than the words, "I am very ill," when asked, "What is the matter, Polly - what is the matter ?" answered, in a dismal tone, stretching himself on the hearth, "I am very ill."

We find also in the annals of Constantine Manasses, a Byzantine writer of the twelfth century, the story of the young Prince Léon, son of the Emperor Basil, who was condemned to death by his cruel father, and though the latter could not be moved to pity by the entreaties of those around him, the accents of a bird which had been taught to lament the death of the young prince, at last softened the barbarian's heart.

The language of the parrot is not destitute of ideas. That this bird cannot form, like us, a chain of reasoning is true; but to say that his language is without an idea is impossible. When you ask a parrot if he has breakfasted, he knows perfectly well how to answer you, if he has satisfied his hunger. He will never tell you that he has breakfasted when it is not the case; at least, you cannot force him to say "no" when he ought to say "yes."

Some young girls, in going to school, passed a house where was a parrot; one of them had beautiful plaits of hair falling over her shoulders. No doubt the parrot had 
heard them call this young girl "the belle with the plaited hair." From that day, every time the child passed before the parrot, without any one saying a word, he recognised her and called her by that title. Evidently the sight of the young girl and her hair recalled to the bird the idea of "the belle with the plaits." $\mathrm{He}$ never addressed this compliment to any other person who passed.

One of the most celebrated talkers was a grey parrot belonging to a Dennis O'Kelly, often called Colonel O'Kelly. Not only could this extraordinary bird repeat a great number of phrases, but he could reply to many questions. He also whistled several airs, and marked the time most correctly. His ear was so perfect, that if by chance he uttered a wrong note he corrected himself and took up the measure at the place where he had been interrupted. Was this simply from memory? Was it not rather intelligence and the association of ideas? This same parrot made known its wants by words, and gave its orders in a tone which showed it was endowed with judgment. The bird is also said to have sung the 104th Psalm, "The Banks of the Dee," and "God save the King." This parrot had been bought for fifty guineas; it died in 1802 .

Herbert has rendered justice to the wonderful faculty of memory in this bird. "I have heard one," he says, "sing about fifty airs of different kinds, sacred psalms, comic and vulgar songs, of which he articulated each word as distinctly as any well-exercised human voice could have done. When he was moulting, and not in the humour to sing, he replied to all solicitations by turning his back and repeating several times, "Polly is ill." Mr. Jesse mentions a parrot which, when pleased, would laugh most heartily, and then cry out, "Don't make me laugh so; I shall die, I shall die." The 
bird would also mimic sobbing, and exclaim, "So bad, so bad ; got such a cold." If any one happened to cough, the parrot would remark, "What a bad cold."

When we understand animals better, we shall not mix up any merely speculative questions with actual facts, but be more ready to admit in these beings an intelligence in harmony with their organisation, their wants, and their feelings.

Where can one find amongst human beings an attachment greater than that of the two parrots belonging to Dr. Franklin? "I have known two parrots," said he, "which had lived together four years, when the female became weak, and her legs swelled. These were symptoms of gout, a disease to which all birds of this family are very subject in England. It became impossible for her to descend from the perch or to take her food as formerly, but the male was most assiduous in carrying it to her in his beak. He continued feeding her in this manner during four months, but the infirmities of his companion increased from day to day, so that, at last, she was unable to support herself on the perch. She remained cowering down in the bottom of the cage, making, from time to time, ineffectual efforts to regain the perch. The male was always near her, and with all his strength, aided the feeble attempts of his dear better half. Seizing the poor invalid by the beak, or the upper part of the wing, he tried to raise her and renewed his efforts several times.

"His constancy, his gestures, and his continued solicitude, all showed in this affectionate bird the most ardent desire to relieve the sufferings and assist the weakness of his companion.

"But the scene became still more interesting when the 
female was dying. Her unhappy spouse moved around her incessantly, his attention and tender cares redoubled. $\mathrm{He}$ even tried to open her beak to give some nourishment. $\mathrm{He}$ ran to her, then returned with a troubled and agitated look. At intervals he uttered the most plaintive cries, then with his eyes fixed on her, kept a mournful silence. At length his companion breathed her last; from that moment he pined away, and died in the course of a few weeks. 


\section{THE EAGLE.}

If the names of certain animals are employed as terms of concempt, that of the eagle, on the contrary, is a synonym tur intelligence, representing to everybody the greatest intellectual powers. And yet few naturalists have observed the intelligence of this king of birds. We must penetrate with Audubon into the primitive forests of America to make observations on this point. "In autumn," says he, " at a time when thousands of birds fly from the north, and draw near to the tropic, let your boat skim over the waters of the Mississippi. When you see two trees towering above all others, side by side on the banks of the river, raise your eyes - the eagle is there. Perched on the summit of one of the trees, his flashing eye seems to burn like a flame of fire. $\mathrm{He}$ contemplates attentively the whole extent of waters, and his look is often directed towards the sun. He observes, waits, listens to every sound, recollects and distinguishes them, and even the step of the fawn, gently moving the leaves, does not escape him. On the opposite tree the female remains as sentinel; every now and then she seems by her cry to exhort the male to be patient. $\mathrm{He}$ replies by clapping his wings, inclining his whole body, and by a shrill cry resembling in sound the laugh of a maniac; then he stands erect, so silent and immovable, one would think he was marble. Ducks of all kinds, water-fowl, and bustards, brought thither by the course of the river, fly past in close battalions, but the eagle disdains such prey, and 


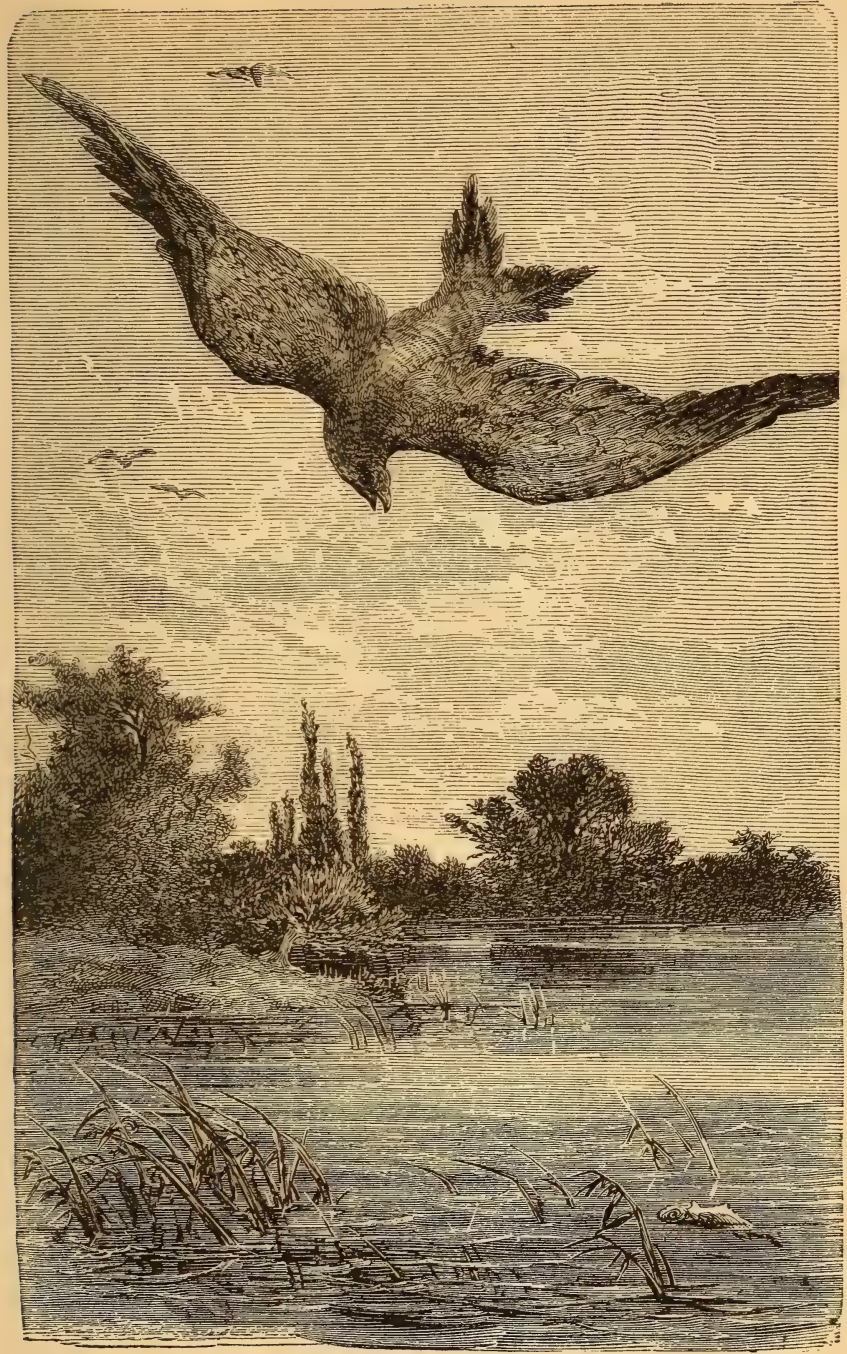

THE EAGLE SEEKING HIS PREY. 

his contempt saves their lives. A sound, which the wind wafts over the current, reaches the ears of the two brigands. This sound has the harshness and reverberation of an instrument of copper. The female warns the male by a call made up of two notes. The whole body of the eagle trembles. Two or three sharp strokes of his beak against his plumage prepare him for the expedition. He is ready to take flight.

"The swan approaches, like a vessel floating in the air, his neck, white as snow, extended before him, and his eye flashing with uneasiness. The precipitate motion of his wings scarcely serves to sustain the weight of the body, and the feet, folded back under his tail, are invisible. $\mathrm{He}$ approaches slowly-a devoted victim. A war-cry is heard; the eagle darts off with the rapidity of a falling star or the lightning flash. The swan recognises his executioner, lowers his neck, describes a semicircle, and in an agony of fear, manœuvres to escape death. He has but one chance, that of plunging into the current; but the eagle foresees his intention, and forces his prey to remain in the air by keeping himself underneath, threatening to strike the belly and under the wings. This deep scheming never fails to attain its end. The swan becomes tired and exhausted, losing all hope of safety. The enemy still fears that the prey may fall into the water; a blow from the talons of the eagle strikes the victim under the wing and precipitates him obliquely on to the shore. So much power, activity, prudence, and skill have completed the conquest. You could not witness the triumph of the eagle without fear. $\mathrm{He}$ strikes his strong claws into the heart of the dying swan, beats his wings, and shrieks for joy. The last convulsions of the dying swan intoxicate him. He raises his 
bald head towards heaven; his eyes inflamed with pride, are red as blood. His mate joins him: both return to the swan, pierce his breast with their beaks, and gorge themselves with the warm blood which flows from it."

"In this terrible drama," says Adrian Leonard, "intelligence is in union with instinct, for it is impossible not to recognise attention, observation, reflection, and forethought which is the result of experience."

The following account of the patience with which a golden eagle submitted to surgical treatment, and the care which it showed in the gradual use of the healing limb, must suggest the idea that something very near to prudence and reason existed in the bird. This eagle was caught in a foxtrap set in the forest of Fontainebleau, and its claw had been terribly torn. An operation was performed on the limb by the conservators of the zoological gardens at Paris, which the noble bird bore with a rational patience. Though his head was left loose, he made no attempts to interfere with the agonising extraction of the splinters, or to disturb the arrangements of the annoying bandages. He seemed really to understand the nature of the services rendered, and that they were for his good. Either from pain or from anger, the eagle refused to touch any of the offered food for thirteen days. A rabbit being then presented, he killed it, taking care not to use his injured claw. On the twenty-first day after the capture he began to experiment on the soundness of the injured limb; trying it first a little, now resting gently upon it, and then throwing more weight upon the foot. The limb at length recovered from the injury, but this result was chiefly owing to the wonderful patience and intelligence of the wounded bird. He seemed also to feel grateful to the man who had tended him during the progress of the cure; 
and such was the perfect confidence established between the two, that the eagle slept on a perch close to the bed of the attendant.

Another fact may be mentioned illustrative of the eagle's ability to select, on the spur of the moment, the best means for accomplishing a result.

Two boys had robbed an eagle's nest, and were going off with the young, when the mother suddenly returned, and made a desperate attack upon the spoilers. The boys defended themselves with sticks, but had the narrowest possible escape from the fury of the exasperated bird. A small stream ran near, and, in order to give greater power to her wing, the eagle, at each swoop, dipped the feathers in the water, and then trailed the wet wing against the sand. Thus prepared, the stroke of the wing told upon the boys with double force. Here we have a bird availing herself of perfectly novel means to meet an unexpected emergency. Mere instinct would not have taught the eagle thus to use the water and sand. 


\section{VARIETY OF BIRD INTELLIGENCE.}

SKILL OF THE TAILOR-BIRD-DEVICES OF THE TOM-TITS AND THRUSHES-THE ROBIN APPEALS TO MAN-JEALOUS PRUDENCE OF THE WREN-DEEP TRICK OF A CORNCRAKE-MATERNAL CARE IN A LARK-COMBINATION AMONG STORKS-LOGIC OF A MOOR-HEN.

That a bird should turn its beak into a sewing-needle might seem a feat above all feathered genius; but the tailor-bird of India has actually done so. The following is the mode in which this winged mechanic constructs its nest :-The bird having selected two leaves of a size suited to its wants, and picked up a bit of cotton-thread, drills a hole in the leaves with the beak, and then, with the same tool, passes a bit of the thread through; a knot being then formed so as to prevent the thread from coming out, one pair of holes is thus secured. The same operation is repeated with each set of holes, until a sufficient number of the leaves is joined to form a nest. This fastening a knot at each pair of holes, instead of uniting all by one thread, as a human sempstress would do with her needle, is a tedious task ; but the bird has not got a needle, and therefore has to work with its natural tools. Surely this operation is evidence of the existence of some power of reasoning.

The stratagem by which a hungry tom-tit will sometimes procure a dinner seems to indicate a power of drawing conclusions from facts. The bird alights in front of a bee-hive 
on a winter's day, and then gives a vigorous tap with its beak on the board at the entrance. It waits a while; a bee-a curious and watchful bee-then probably comes out, in spite of the cold, to see what can be the matter. It is the insect's last journey in pursuit of knowledge; the tomtit picks him up, in defiance of the sting. Proceeding in this manner, the cunning bird manages to get something like a dinner. The tom-tit seems to reason thus: "If I tap, the bees will be alarmed; some are almost sure to come out, and then they are mine."

The lapwings and thrushes obtain breakfasts of worms by a very similar process. Advancing until a worm cast is visible, the bird jumps violently on the ground; in a short time the worm generally comes out, whether from fright at the singular shaking of the soil over his head, or from curiosity, we cannot say. No sooner, however, does he wriggle out, than he is captured, without possibility of rescue.

The robin is well known to be a bold bird, fighting all small birds, and showing in the winter little fear even of man himself. But a fact is recorded which suggests that the redbreast can reason upon the ability of man to help the weak.

Mrs. Lee, in her "Anecdotes," says that one day her gardener was struck by the strange conduct of a robin, which the man had often fed. The bird fluttered about him in so strange a manner-now coming close, then hurrying away, always in the same direction, that the gardener followed its retreating movements. The robin stopped near a flower-pot, and fluttered over it in great agitation. It was soon found that a nest had been formed in the pot, and contained several young. Close by was a snake, intent, doubtless, upon making a meal of the brood. The man 
saw the reason of the bird's conduct, and carried off the snake, upon which the redbreast expressed its joy by a burst of song and triumphant flutterings. Here was a direct appeal made by the robin to the man for aid against a foe.

Sometimes, however, birds will not confide in man, but prefer to rely on their own resources.

Mr. Jesse gives an account of a wren which had been annoyed by some children peeping into her nest. No harm was intended; the children would not, on any account, have hurt the wren. But the bird suspected danger, or, at least, objected to be overlooked. One day the opening into the nest was found to be closed up. Had the cruel mother actually buried her young alive, and turned their cradle into a tomb? On closely examining the nest, it was discovered that a new entrance had been made at the back, into which the wren clearly thought no eye would pry. What could a human householder have done more to secure himself from impertinent curiosity? If overlooked through the front windows, his reason would lead him to close them and open others at the back. Thus the wren acted.

When an unarmed man is suddenly attacked by a bear, and falling on the ground pretends to be dead, he is thought to have displayed great presence of mind. This can be matched by an incident in the life of a corncrake.

One of these birds had been brought to a gentleman by his dog. The corncrake was to all appearance quite dead when laid on the ground, not a feather moved; when turned over, the whole body seemed lifeless, and the sportsman left it on the ground awhile. He took it up hastily, for he had seen one eye slowly open; perhaps the poor bird was not dead. But there it hung in his hand, in all the drooping lassitude of death. The bird was then placed in his pocket 
but in a short time it was certainly moving; and yet, upon again looking at it, there was no stir. The gentleman then, somewhat perplexed, laid the corncrake on the ground, and withdrew to a little distance. In a few minutes an eye was slyly opened; then the head was slowly raised; and, lastly, the artful bird got upon its legs, and darted off in thorough corncrake style. Are we wrong in calling this "presence of mind." The case seems to be well attested, both Mr. Jesse and Mrs. Lee admitting it into their works.

Birds which build their nests on the ground are exposed to special perils, and therefore adopt every precaution to screen the nest from observation. How often does the mower's scythe bring instant death to the lark while sitting on her nest? It happened that on one occasion the scythe passed clean over a lark's nest, neither injuring the mother nor disturbing the young. The cutting away of the grass had, however, laid the home open to every passer-by. The mowers went on with their work, and the courageous bird remained at her post of danger. After a short time the farmer passed, but could see nothing of the nest. After some close searching, the concealment was explained. The lark had actually placed over the nest a quantity of grass, so arranged as to hide the whole completely from view, but leaving a passage wide enough for her to go out and return. This case shows an intelligence adapting itself to the sudden emergencies of an unexpected crisis, which must be something more than instinct.

Storks seem to have some means of so communicating their wishes to each other as to be able to organise plans and combine to carry them out.

One day a wild stork attacked with great fury a tame member of his race, kept, with clipped wings, in a yard at 
Tübingen, but was driven off by some men. The next year four storks attacked the tame bird, but were driven off by the people, who were irritated at these assaults on their favourite. For some time the precautions taken kept the wild storks at a distance; but, in the spring of the third year, an organised band of near thirty storks dashed into the yard where their tamed brother was kept, and murdered him before aid arrived. The original ground of quarrel is unknown; but it seems clear that these repeated attacks, with constantly increasing numbers, were the result of concerted action among the conspirators.

The same power of combination was shown by two moorhens. One of these birds saw a pheasant feeding from a box which opens by a spring set in action by the weight of the pheasant on a perch. No sooner had this bird left the perch one day, than the moor-hen occupied the place, waiting till the food-box opened. But this result did not follow, because the moor-hen's weight was rot sufficient to act on the spring. For a time the mortified bird tried to get the door open by jumping on the perch; but this being of no use, it flew off, and soon returned with another moor-fowl. The weight of the two birds brought the spring down, and the ingenious thieves were rewarded by feasting on the pheasant's food. Bishop Stanley, who recorded the case, has no doubt of its truth; and the proceeding of the two birds certainly looks like rational combination. 


\section{THE SWALLOWS.}

\section{GENTLENESS.-FIDELITY AND BROTHERHOOD.}

Francis of Assisi being occupied one day in preaching to an idolatrous population, the chattering of some swallows prevented his words from reaching the ears of his audience; he addressed himself immediately to his interrupters in these terms: "How many hours you chatter, my sisters; pray keep silence a little while, so that I may also speak in my turn, and explain to these good people the word of God." "These swallows," says the story (for the accuracy of which we do not vouch), "became silent immediately, and listened with profound attention to the words of the preacher!"

St. Francis, who certainly was not a simpleton, had probably remarked the intelligence of these charming little birds. He knew without doubt, also, that the Psalmist compares a pious man to the swallow, which loved to suspend her nest in the arches of the Temple. The confidence with which swallows build their nests in churches and under our roofs may be deemed proof of their intelligence. It has been remarked that the nearer animals live to man the more their intellectual aptitude is developed. Toussenel is, without contradiction, the author who has spoken best of the swallows. "People have reason," said he, "to call swallows the birds of God, because there is no species of animal on which the Almighty has, with more partiality, shed his gifts. It surpasses the turtle-dove and 
common sparrow in tenderness, Philemon and Baucis in fidelity, the partridge in maternal devotion, the wagtail in social love, and the falcon in power of flight and keenness of vision. The swallow is essentially the friend of man ; in countries where the children have no pity for other birds, the swallows are respected. It is no uncommon thing to see ten, fifteen, and even twenty swallow-nests under the roof of a farm-house. The worst man dare not touch them there; this is not oniy from a sense of pity for these innocent creatures, which rid us of numbers of destructive insects, but because men think that to destroy the nest of a swallow brings ill-luck. If there were no worse superstitions we could well leave the people in their belief, while the swallow herself can afford them lessons of conjugal fidelity and maternal affection. The union of swallows lasts as long as their affection for the places of their birth, or the scenes of their first love."

Science has not sufficiently analysed all the circumstances which accompany the death of so many swallows by drowning. In these cases of violent or premature death, we see charitable neighbour birds take charge of the offspring of the defunct pair, and generously provide for the support and education of the poor orphans. What a lesson for bad mothers, who have not the same care for their own children, but sometimes leave them like a bundle of soiled linen in the public streets when they cannot dispose of them otherwise! How can any one say that a creature with so many good instincts is not intelligent?

'The house-swallow, says Dupont, is distinguished among birds by its intelligence. Its tenderness for its little ones, the gratitude of the latter, conjugal, filial, and paternal love are constantly displayed in the nest, mingled with a 
variety of affectionate and tender expressions. All the members of the family feel an affection which they cannot contain, and which they manifest by a delicious warbling; all seem to be desirous of saying, "I love thee, thou art beautiful and good!"

However, when about to render service to a neighbour, the voice which demands help, and that which grants it, may be distinctly heard. Many persons know the story of the swallow which had entangled its claw, by some means, in a piece of thread fastened to a spout on the wall of the Collége des Quatre Nations, at Paris. Its strength being exhausted, the bird hung at the end of the threar, which it kept raising in the endeavours to fly, uttering plaintive cries. All the swallows from between the Pont des Tuileries and Pont Neuf, and perhaps still further, gathered

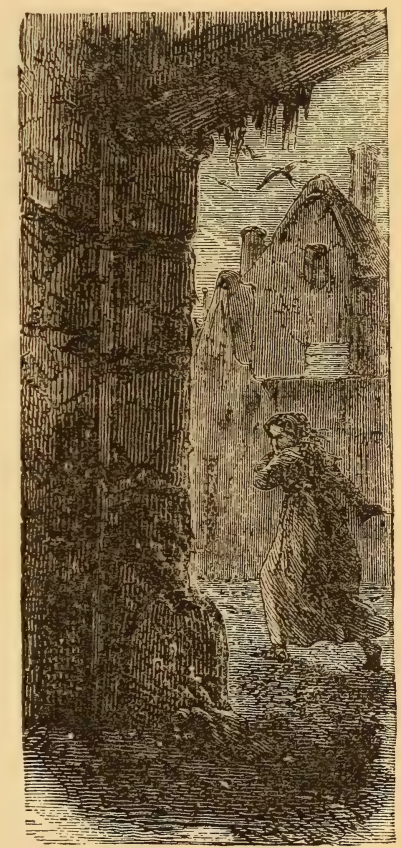

A Lesson for Bad Mo.hers. together, to the number of some hundreds, all uttering cries of pity and alarm. After some hesitation and a tumultuous conference, one of them seemed to have found a means of delivering their unfortunate companion, and no doubt communicated it to the others. They placed themselves in order, and each coming in turn, struck the thread with the beak, somewhat after the fashion of 
"tilting at the ring." These thrusts, aimed at the same point, succeeded each other every moment, and greatly incommoded the poor captive; but in a short time the

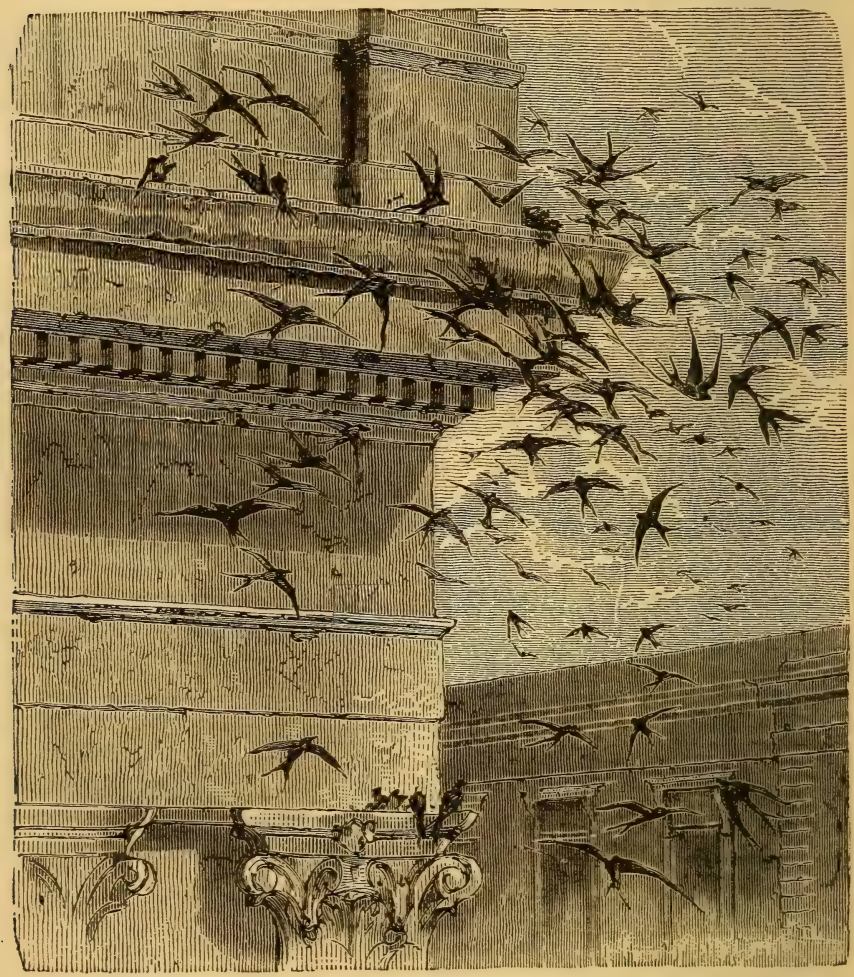

Combination among the Swallows.

thread was severed, and the poor bird set at liberty! The flock remained till night, chattering all the time; but in a tone which had nothing of inquietude, and was expressive only of mutual congratulation. 
A sparrow having taken possession of the nest of a swallow, defended it most vigorously. The former possessors not being able to recover their heritage, invoked the aid of their confederates, who, notwithstanding their numbers and menaces, were not able to dislodge the usurper. All their attempts were in vain. Suddenly their manœuvres changed; the assault was suspended, and the siege turned into a blockade. Some brave swallows stood sentry over the opening, and the others bringing their beaks full of mortar, in a short time the nest was walled up like the fatal prison of Ugolino. The cries of the vanquishers intimidated the sparrow from attempting to make its escape. The consolidation of the wall was soon complete, and the usurper perished.

The following case also shows the readiness and ability of these little birds to combine against their foes. In the year 1832 a pair of swallows built their nest under the eaves of a house at Hampton Court. A pair of sparrows got possession of the home, and the swallows were unable to expel the impudent intruders. But when the usurpers had to leave the nest in search of food for their young, then came the time for revenge. During the short absence of the sparrows a number of swallows tore down the nest from the wall, and left the unfortunate young ones to perish, thus proving that even birds may sometimes suffer through the faults of their parents.

Numerous, indeed, are the cases in which swallows show a sympathy for the welfare of their race. A nest, containing young, had been beaten down by long continued rains, and the brood was thus exposed to the pelting storm. Some members of the family inhabiting the house threw a cloth covering over the ruined nest, and thus saved the newly 
fledged birds from perishing. But now loud outcries arose from the parents, and from other swallows which instantly flocked to the place. When the storm had passed the covering was removed, and then an extraordinary scene was witnessed. The old birds fed the young, and immediately all the assembled swallows set to work in raising an arched earthwork over the nestlings, and thus effectually protected the young family. What could a colony of human settlers have done more for a neighbour whose house had been destroyed? No theory of mere instinct will explain such a proceeding. The emergency was sudden, the remedy novel, and the means effectual.

Something like reason is seen in the following case :An American wren took possession of a martin's nest, from which the invader could not be expelled. The martins, however, kept watch over the intruder, and no sooner did the wren leave the nest to search for food than the martins re-entered, and immediately planned a scheme for keeping out the foe. They made the entrance so much narrower, and so blocked up the passage that it would be impossible for the wren to get in, while the owners kept at home. The enemy soon returned, and at first tried force, but the strength and arrangement of the defences baffled her. The foe now established a siege, watching near the entrance for two days. But the martins bravely held out in spite of hunger, and at last, the patience of the wren giving way, she left the skilful defenders of the fortress in peace. Here, again, we find birds adopting special means to accomplish a particular end.

Mr. Jesse mentions the following as illustrating the intelligence of the swallows in adapting even the materials of their nests to special situations. A pair of these birds built against the wall of a lime-kiln chimney. The heat was 
so great as to make the nest crumble to pieces; a second and even a third sharing the same fate. Some scheme for making or collecting a new kind of material, capable of bearing the heat, must then have been devised, for the fourth nest stood. For two succeeding years the nests were built in the same place and always endured the heat. Between the first unsuccessful and the last improved works of the little architects, some progress must have been made in the composition or working up of the material for the nest. These swallows were inventors in some way, as clearly as Wedgwood was in his pottery improvements.

Another incident, mentioned by the same gentleman, supports a similar conclusion. A swallow had selected a place for her nest in a corner formed by two walls, but the surface of these being smooth, the bird could not easily find any projection on which the foundation of the nest might rest. She, however, managed to fix a bit of clay on each wall, and then laid a piece of light wood on the two clay supports. This gave her a good foundation, and the work was securely finished. Is a builder who overcomes a structural difficulty to be counted a clever workman, while similar triumphs over obstacles by a bird are all explained by the vague word "instinct?"

One can well understand, from these facts, the energy, union, subordination, and social spirit employed in common defence and the general interest.

When about to migrate, the swallows assemble at some place apparently agreed upon beforehand; and, after a long discussion, which occupies whole days, they set out in flocks. It is said that the principal sign which warns them of the necessity of leaving a country, is the slight elevation of the sun in autumn. Birds are, in fact, very sensitive to light. 


\section{THE RAVEN, ROOK, AND MAGPIE.}

THE raven does not inspire us with much interest. His black coat, lugubrious air, his destructive instincts, and his inclination for theft, have procured him much abuse. On the other hand, his hypocrisy has not procured him many friends. Sometimes he crows like a cock, mews like a cat, barks like a dog, or imitates the sound of the rattle, with which they frighten the birds from pillaging the fields of corn.

$\mathrm{He}$ is capable of learning a little Latin. Dr. J. Franklin's raven, which was named Jacko, pronounced the word aqua distinctly, but he preferred wine to water. "One day," said the Doctor, "my housekeeper placed a glass of red wine upon the table; in an instant the bird poured it quickly down his throat, I mean that he plunged his beak into the precious liquor, and sucked it up, drop by drop. When the housekeeper, fearing he would break the glass, took it away, the bird flew into her face in a fury. If three glasses are placed upon the table, one of water, another of beer, and the third of wine, he will leave the first two, and will only pay his respects to the glass of wine. We may conclude, then," said the Doctor, "that these birds are not so limited to the dietetic regimen prescribed by nature as to show themselves insensible to the good things of the kitchen or the treasures of the cellar."

Many writers have remarked the intelligence and sagacity of ravens in judging of the dangers to which they are 
exposed by our weapons. A very lofty and bushy oak, far from any habitation, served as a shelter during the night for a number of ravens. Thither they were seen to retire every evening. One very clear night, about two hours after sunset, a gun loaded with ball was fired into the tree. The ravens took to flight, but not one of them flew horizontally; on the contrary, all rose perpendicularlv like a burst of fire-

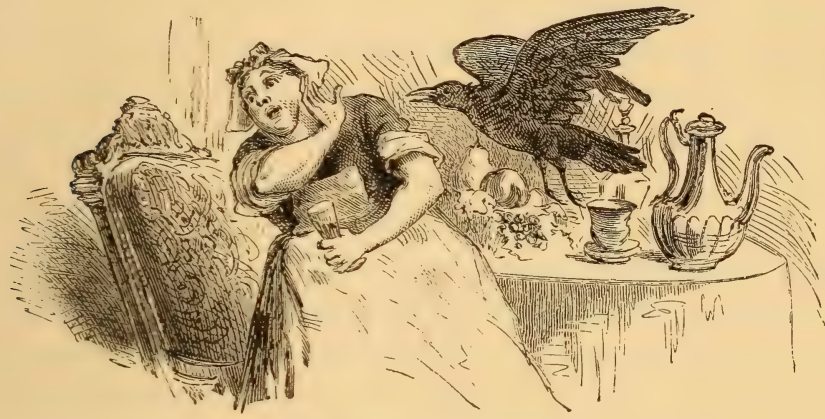

The Raven fights for the Wine.

works. Their unanimous calculation seems to have been, that the shot which had been fired from the foot of the tree might be followed by another, therefore it was best to rise out of reach in a direction where the branches could protect and hide them. It was not until they were at a great elevation that they began to disperse in order to choose another resting-place.

During the day, when the flock strayed through the fields in search of food, five or six sentinels remained in the air, flying slowly from side to side, observing all that passed, and giving the others due warning. These watchers were relieved at certain intervals.

The habits of ravens can rarely be watched in England 
now, few indeed of these birds being found in the more cultivated districts, especially in the south. If the following statement, published about a hundred years ago, is to be relied on, the ravens must sometimes have shown a capacity for combined action against foes. A blacksmith, of Bridgewater, went out about Christmas to enjoy a little shooting; a number of ravens flew by, the man fired, and two birds dropped. The rest instantly attacked the sportsman, dashing their powerful beaks into his head and face; nor were they driven off before the shooter had received many severe wounds. Indeed, the man is said to have died a few days after.

If the old and widely-believed story could be accepted, which describes the raven as throwing pebbles into hollows containing water, in order to raise the fluid to a point within the reach of his beak, we must then class this bird among the sagacious animals. Such an act would imply the possession of some reasoning power. Great men, such as Lord Bacon, have declared their belief in the statement, but it is not sufficiently supported by any well-attested observation.

There can be no doubt, however, that ravens show great skill in obtaining food. The two, mentioned by Captain McClure as watching every movement on board his ship in the polar regions, were constantly outwitting a watchful dog by stealing his food. They would entice the angry quadruped to follow them for a distance, and then, suddenly flying back, would arrive at the mess-tins of the crew, and snatch off the best bone before the dog could return.

It is much easier to note the customs of crows and rooks, as these active and clever birds abound in every county. The cleverness of the rook is well known, and no one who 
has observed them can hesitate to believe that these birds possess a strong memory, great prudence, and some capacity for reasoning. The keen watchfulness with which they regard a man armed with a gun must have been noted by every one. The common notion that rooks can "smell gunpowder" may be wrong, but the old birds can certainly draw a very fair conclusion respecting the power of a gun to do them mischief. One warning note from the sentinel rook is enough to send off a whole colony from its feeding ground. The people in some parts believe that the rooks distinguish Sunday from other days, and will then approach places from which they generally keep at a safe distance. The notion is by no means unreasonable. So watchful a bird must notice many things which distinguish Sundays. The absence of work in the fields, the general quietude of the country, and the sounds of church bells coming from all parts, are quite sufficient to impress upon the memory of a rook the most evident marks of such a day. The strength of memory in these birds cannot often be tested, as they are seldom domesticated; but there are instances which show that the rook can long remember persons with whom it has associated. An American gentleman had brought up one from the nest, which became the pet of the whole family ; but the love of liberty could not be destroyed. One day the bird disappeared, nor could any news be obtained of the wanderer. Eleven months had caused the rook to be forgotten, when one day a number of the birds flew by, and one, coming boldly down, perched on the gentleman's shoulder, uttering the most joyful cries. There was no doubt about the old friend; certain marks enabled the former owner to identify the fugitive, and he tried to lay hold of the confiding bird. Then it flew back; it would 
recognise and salute him, but it must remain free ; therefore, after much fluttering to and fro, the exile flew off to its companions. The memory of this bird had enabled it, after so long a time, to recognise not only the appearance of the former owner, but there must have also been the recollection of kindness received long ago, otherwise such perfect confidence in man would hardly have been shown. Thousands of such instances might be obtained if our opportunities for observation were more extensive.

Rooks are said to possess, in a large degree, the faculty of sympathising with the wounded of their own race. They do, undoubtedly, flutter in the greatest agitation over and around those which have been disabled by shots. If the injured rook is able to move, the others call him forward with incessant outcries, and show their anxiety to remove him out of danger.

Some persons look upon magpies as mischievous chatterers rather than as clever birds. Some of their nests, however, show no small degree of defensive skill, especially in places where enemies abound. Mrs. Lee describes the proceedings of a pair of these birds, which, having built their nest in the low part of a gooseberry bush, where it was exposed to the attacks of cats, found themselves compelled to fortify their home. Well was the work accomplished. A complete barricade of thorns was firmly fixed round the nest, and even round the bush itself. This bird fortification was nearly a foot thick, bidding defiance to every assailant except man himself. The magpie does, no doubt, often employ its ingenuity for very improper objects. One is mentioned who used his power of uttering words to impose upon mankind. He belonged to a family which lived near a toll-gate, and from often hearing travellers utter the cry, had learned 
to pronounce the words "gate ahoy." The bird had also observed that the utterance of these words invariably brought out the keeper's wife to open the gate. Combining these various points in his clever little head, the bird contrived a scheme for plundering the good woman. On certain days she prepared the dinner in a kitchen from which the toll-gate was not visible, but the traveller's call compelled her to leave all her delicate little bits on the table for a few minutes while the gate was being opened. Now the magpie coveted some of these morsels, and one day, when the woman was preparing the dinner, the well-known cry, uttered in a peculiar voice, "gate ahoy," compelled her to leave the kitchen. To the amazement of the woman, she saw no traveller, nor was there any malicious boy in sight who might have played the trick. On returning to the kitchen she beheld the magpie pecking with might and main at her eatables. The thief soon made his escape from the angry woman, who did not at first suspect the bird as the culprit; but when the trick had been played two or three times, the whole scheme was clear. The magpie's cheating then came to an end, but his fame spread far and wide. In truth, we are sorry to admit that the cleverness was so applauded that the crime was overlooked. In this trick we can all see that the bird must have combined in one view a number of facts, and have reasoned correctly from them. 


\section{THE PARTRIDGE.}

THE partridge has not a strong head, it is true; but ma. ternal devotion is so manifested in this poor little creature that her heart must be the great source of intelligence. We do not know a better assorted union than that of the partridge. The male, once mated, is as tender and faithful as his companion. Both love with all their heart, without fear or hesitation. The female deposits about twenty eggs, on which she sits with unequalled ardour during twenty-four days, and takes care to place them in such order that every one shall receive an equal amount of heat from her body. During the whole time of incubation, the male, a model husband, is ever by the side of his companion, with a solicitude, a happiness, and a kind of rapturous admiration, being ever ready to accompany her when she leaves the nest in search of food. As soon as the little ones are hatched, he shares with the mother the cares of their education; they lead them in common, call them incessantly, show them the food suitable for them, and teach how to procure it by scratching the earth with their claws. It is not an uncommon thing to see the old birds sitting down side by side, their wings covering the little ones, whose. heads are peeping out on all sides. And then, if the sportsman's dog, having scented the nest, approach too near, it is always the male who takes flight first, uttering cries of distress, which betray his agony. He does not go away far; but stops at the distance of thirty or forty paces, hoping 
that all is not lost, and that the dog will have pity on his beloved family. But, no; the dog knows no pity for them. Then paternal love can no longer be restrained; the poor bird, not regarding his own weakness, sometimes

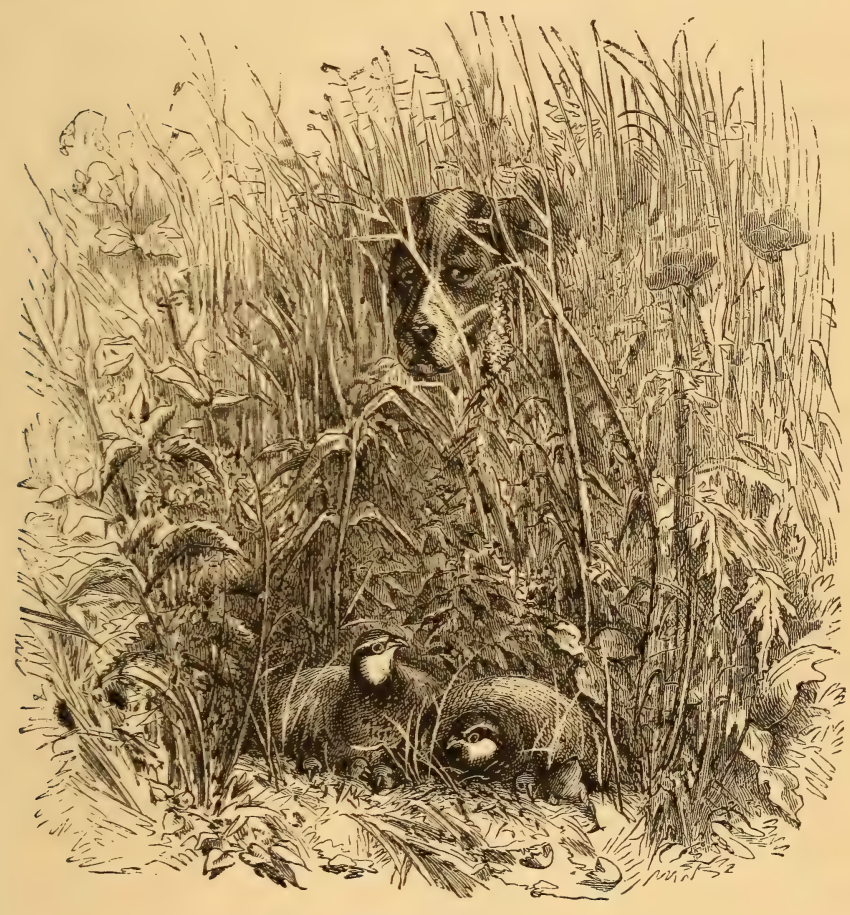

The Crisis.

even beats the dog with his wings. In a little time he again takes flight; but flies heavily, dragging his wings, as if to attract the enemy by the hope of an easy prey, always flying far enough, so as to escape being taken, but not far enough 
to discourage the sportsman. Thus he contrives to draw him further and further from the brood. La Fontaine attributes this sagacious manœuvre also to the mother-bird.

Buffon says that the female takes flight the instant after the male; always goes further, and in another direction. She does not despair; but returns immediately, running along the furrows, and approaching her little ones, all hidden in the grass, gathers them together quickly, and before the dog returns from pursuing the male, she has conveyed them far away, without the sportsman hearing the least sound.

A nest was so placed on some land which was being ploughed that the next turn of the share must destroy it. When the ploughmen came to the spot, the nest was there in the very line of the plough, but the birds had gone, and all the eggs, in number about twenty, had disappeared. The men searched, and found the hen about forty yards off, sitting on the eggs, which were on the point of being hatched. In about a quarter of an hour the birds had managed to remove all the eggs. Here was a clear estimate of the danger, and the adoption of the best means of escape. 


\section{THE GOLDFINCH.}

EVERYBODY knows how skilfully goldfinches build their nests; but here is a proof of their intelligence. A pair of goldfinches had built on a branch which was not strong enough. When the brood was hatched, the parents perceived that the weight of their growing family was too heavy for the branch, and that it was on the point of giving way. In order to save the nest from a fall, which appeared imminent, they formed the idea of binding the slender branch to a stronger one close to it. At last, they strengthened all, by means of a little stick which they had picked up.

Toussenel relates that, in the reign of Louis Philippe, there was, in a little town of the Oise, distant about twelve leagues from Paris, a goldfinch whose intelligence surpassed the common order, and which, for a long time, enjoyed deserved popularity in his native country. $\mathrm{He}$ belonged to a courier, who journeyed twice a week to the capital, and the bird had been accustomed by degrees to accompany his master in these expeditions. At first he limited himself to flying before the carriage, and resting occasionally on the front of the imperial, where his master was seated. He flew away now and then to chatter with the birds of his own species, which he met with on the way.

But the finch was soon tired of the slowness of the fourwheeled vehicle, and by degrees accustomed himself to take 
long flights in advance, going the whole of a stage to an. nounce the expected arrival of his master at the hotel of the great city, where he waited quietly at a corner of the fire, when the weather was stormy, or flew out to meet his owner when the sky was bright.

This charming friendship of man and bird lasted several years, during which time every inhabitant of the town in question had witnessed each day a convincing proof of this

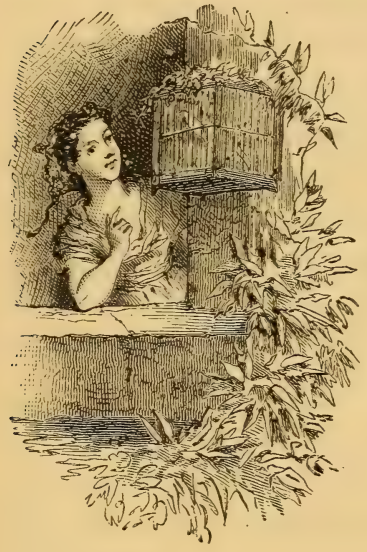

Love in a Cage.

philosophical truth, that all sagacious animals have been created to love and serve man, and that the secret ambition of the most intelligent is to be near him.

Another example of the attachment of the goldfinch is related by M. Oscar Honoré, in his work entitled "The Affections of Animals." A canary and a goldfinch shared the same cage, and, notwithstanding the difference of their origin, the pretty captives lived together on the best of terms. They caressed, and tried to outvie each other in singing and warbling; it was indeed a perpetual concert. But one day, when the young lady of the house was putting a piece of cake into the cage, the canary slipped through her hand, and taking French leave, flew away. Immediately the goldfinch wished to follow its example, but was stopped in its career, and from the bottom of its prison answered the joyous calls of its runaway companion. From this moment the goldfinch ceased to sing. Crcuching in a 
corner, all of a heap, his head hidden beneath some grass. he would neither eat nor drink, perceiving which, his young mistress went in quest of another canary. The next day she brought him a new companion, and at first believed in the efficacy of the remedy, for the poor prisoner hearing the sound of wings near him, raised his head, changed his position immediately, and began to whistle joyfully; but the illusion was of short duration, he quickly perceived it was not the one he regretted, and as the noise of the new comer only wearied him, he crept into his feedingplace, resumed his former position, and the next day was dead.

The history of the suldfinch abounds with similar examples of attachment, and his intelligence is on a par with his generosity. Everybody knows the absolute devotion of the male to the female, the family affection which characterises the species, the grace and vivacity of their language, and their wonderful architectural talent. But the study of the captive goldfinch is still more interesting than that of the free bird. A tame goldfinch having found that a stale piece of bun, by reason of its hardness, was quite uncatable, until it had been softened by exposure to a shower of rain, profited by this experience, and ever after soake 1 any food given him in water.

We may relate another proof of the intelligence of the goldfinch. It is well known that this bird constructs its charming little nest in three days. This nest is generally made of down, grass, horse-hair, wool, and moss. But the birds do not always use the same materials, which is a proot they are not guided by instinct aione.

A pair of goldfinches were seen to change the materials of their nest three times, at the will of the proprietor of the 
garden, where they had established their domicile. The first day he gave them some wool and they made their bed of that material. The second day he put within their reach some wadding, which they substituted for the wool. The third day he gave them some fine down, which soft substance they immediately used for the nest. 


\section{THE CANARY.}

How can any one say that the canary is devoid of sense? Is there a form more animated, a brighter eye, a finer or more charming little head, than that of this lively bird, whose structure is so delicate, colour so soft, feet so slender, and movements so graceful? The canary is all gentleness and vivacity. Our favourite canaries are nearly always singing, tame, good-tempered, sweet in disposition, good husbands, tender fathers, and naturally happy. They cheer their mates incessantly by their singing, relieve them in the labour of hatching, and take their places for several hours during each day; they also join in feeding the young ones, and in teaching them all that is necessary.

In proportion to the weight of their body, their brain appears more developed than that of man.

These birds are very docile and teachable. They will lay aside their own natural melody to take up the harmony of our voices and instruments. They can learn to whistle, and even to speak. The facility with which they learn different kinds of performances is another proof of the docility of their intelligence. We have seen some at a fair which went through their exercises with the precision of old grenadiers.

Fée relates how these little creatures afforded the spectators much entertaining and interesting amusement. They pretend to fall down as if shot; their comrades come 
and carry them off. They guess the meaning of certain cards, draw little cannons, pretend to charge and then to fire them; they mount guard, manœuvre at the word of command, and place sentinels. "Partridges," adds Fée, "have been taught, but. less frequently, to do the same tricks."

One of our friends possessed a male and female canary, which, having no materials for making a nest, hit on the expedient of tearing out the feathers of their first brood to prepare a bed for the second.

According to Toussenel, the original rc of 'he Canary Islands is the most skilful, most inteiligert, and most indefatigable of songsters. 


\section{THE SLANDERED BIRDS.}

\section{GEESE.}

WHEN observing their awkward gait, long neck, and gaping bills, the geese appear heavy, stupid, and awkward; however, they are not so stupid as they seem. Their eye, less quick than that of the eagle, shows a certain amount of dignity and intelligence. It is true they have not strong heads, but they have good sight, a keen ear, and their vigilance is seldom at fault. During their sleep, or at feeding time, a sentinel, with head and neck extended, is always there, ready to give a signal to the flock in case of alarm. Having saved Rome, it certainly cannot be regarded as an emblem of stupidity.

In Scotland, a young goose had formed such an attachment for its master that it followed him

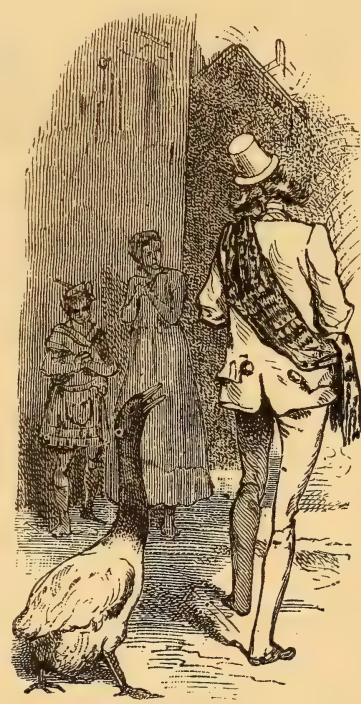

Goose Attachment. everywhere, no matter how great the distance, and even through the crowd and tumult of a city. One day this gentleman walked down one of the most frequented streets, and 
entered the shop of a barber to be shaved. The bird waited patiently while the operation was being performed, then accompanied its master to the house of a friend, after which it returned home. It is said that geese do not recognise

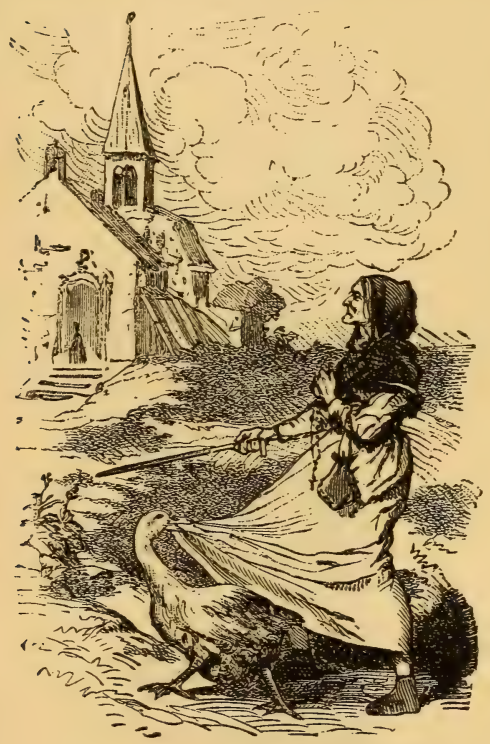

A Goose acting as Guide. their master when the latter has changed his dress. The change of appearance, in this case, does not appear to have caused any doubt in the sagacity of this bird. It recognised its master in any dress, seemed to know his voice, and expressed its satisfaction by cries. In Germany, an aged blind woman was led to church every Sunday by a gander, which dragged her along, holding her gown in his beak. As soon as the old woman was seated in her pew, the gander retired to the churchyard to feed upon the grass, and when the service was ended, he conducted his mistress to her home. One day the pastor called to pay a visit to this person, but found she had gone out; on his expressing some surprise to her daughter, that she should trust her mother to go out alone, she replied, "Oh, sir, we have nothing to fear, my mother is not alone, the gander is with her !" Wild geese are also gifted with remarkable sagacity. They fly 
without tumult; and the order in which their journey is accomplished, supposes, says Dr. Franklin, a high degree of intelligence and combination. There is an arrangement, a method, a system, in virtue of which each individual keeps his rank and follows the body of the army with as little fatigue as possible. They place themselves in two oblique lines, forming a triangle, or in a single line when the battalion is not numerous. The bird at the head of the triangle cleaves the air first; when fatigued, he retires to the last rank to repose, and others take his place by turns in order. We have also observed the same mode of flying amongst the bustards, which are numerous in some countries.

The goose appears to be constant in its affections. It knows also how to show anger. I remember, when a child, if we met with any geese, we used to tease them in order to make them angry. They would run after us in a rage, seize hold of our clothes, and nip us vigorously, to punish us for our insults.

Geese are sometimes singular in their attachments. We knew one which never seemed so happy as when the cat was sitting on the back of the bird. The friendship which existed between these most dissimilar animals was of too singular a character to be often seen. 


\section{TURKEYS.}

\section{THEIR COURAGE AND DEVOTION.}

TuRkeys are not less stupid-looking than geese. Their still smaller head, heavier body, and grating cry, do not plead in their favour. Certain old women, generally tall, with red noses, gourmands by nature and drunkards by habit, always grumbling out some unintelligible words, often appear to have some relationship with turkeys. Toussenel has given a satirical description of the turkey. "It is," said he, " a glutton of the worst kind, making his belly his god, and knowing well that he is doomed to the spit, takes the trouble of fattening himself, so that there is no need to aid this natural disposition by any surgical operation. His extreme voracity is the reason that he often chokes himself while eating, and thus earns for him the name of 'the glutton' in the countries bordering on the Loire. Besides, he carries the marks of all his vices on his stupid physiognomy, and has not one note of intelligence. It is said that a bad, senseless man resembles a turkey. It is truly a flattering portrait. The turkey is more than stupid and wicked, more than a glutton and dotard. $\mathrm{He}$ is bald like all bons-vivants; he has a face, forehead, and cheeks disfigured by bunches of warts and chaplets of red fleshy excrescences, caused by the excesses of the table! These characteristics recall the physiognomy of the vulture, which 
the turkey resembles in size, colour, cowardice, and voracity.

"The vulture is a usurer of the worst kind; the turkey is a thick-headed worldling, a financial upstart. There is surely a physical and moral relationship between the two types. The turkey also carries, at the bottom of his neck, a tuft of black hair, an emblem of his brotherhood with the goat. This model of gourmands, drunkards, and idlers, has an irascible temper. Like rich people of modern times, you hear him always blustering and gobbling; you see him always red or blue with anger."

After so terrible a portrait of the turkey, who will dare to say anything in his favour? Is there any living creature on the earth that has no good quality? We cannot think that there is an animal to be found anywhere in creation, however vile, which has not some redeeming quality. Epicures will tell you that the flesh of the turkey is extremely delicate. Philosophers, who plead in favour of the female sex, will affirm that the hen-turkey is the most courageous and devoted of mothers; that she will rather die of hunger than leave her eggs. Turkeys, notwithstanding their proverbial stupidity, are often very cunning. Audubon says that the wild turkeys, being accustomed to perch on the naked branches in flocks, are easily discovered by the large screech-owl, which flies silently, and frequently surprises them. Sometimes, however, its presence is announced by a cry from one of the turkeys, and in an instant they are all watching the movements of the enemy, which, however, selects a victim, and darts upon it like an arrow. It seems inevitably lost, unless indeed it can manage to lower its head quickly, and spread out its fan-tail to oppose a barrier against the strong talons of its assailant. The owl then 
finds only a slanting shield, on which she slips about, without being able to seize anything but feathers. The turkey immediately jumps to the ground, having lost only a few quills.

It has been thought, up to this time, that among the gallinaceous birds, the love of offspring was the exclusive privilege of the female; this fact has been attributed to polygamy. But here is an exception to the rule. A turkey-hen was about to sit; the male, having been separated from her, appeared so unhappy in his solitude, that the owners placed him with his companion. $\mathrm{He}$ immediately crouched down close to the hen. They thought, at first, it was simply a mark of affection, but soon discovered that he had taken some of the eggs under his wing, and covered them most carefully. The servant who had charge of the poultry, thought this method of hatching would not be very successful, and replaced the eggs under the hen; but the male was no sooner at liberty than he again took some under his charge, as he had done before. The master having observed the circumstance, resolved to run the chance of the experiment, and left the turkey to follow his inclination. He ordered a nest to be prepared with as many eggs as the large body of the turkey could cover. The turkey appeared delighted with this mark of confidence, he sat over the eggs with a patience truly maternal, and was so attentive to the duties of incubation that he scarcely allowed himself time to go in seach of food. At the expiration of the usual time, twenty-eight young ones pierced their shells. The turkey who was, in some respects, the mother of this numerous brood, seemed somewhat perplexed when he saw this family of little ones pecking around him and claiming his constant care. They were 
taken from him for fear he should neglect them, or crush them with his great claws.

The turkey mentioned by Audubon showed a degree of memory and intelligence not often witnessed in these birds. Audubon had brought up this turkey from the nest, and it had become perfectly familiar with all the dogs on the farm, near the Ohio. One morning, Audubon being in the woods with his dog Juno, saw in the distance a fine turkey, which he supposed to be a wild one, and sent Juno after it. When the dog came near the bird, Audubon saw with amazement that each animal seemed on the best of terms with the other. It was the pet turkey which had strayed into the wood, and recognised Juno apparently before the dog detected her bird acquaintance. 


\section{THE CRANE AND THE DRAKE.}

Sомe years ago a gentleman possessed a pair of slate-coloured cranes. One of them, the female, died, and the survivor seemed inconsolable. According to all appearance, he would soon follow his companion, when the master thought of bringing a large looking-glass into the aviary. The bird no sooner beheld his own image reflected, than he placed himself before the glass, made his toilet by smoothing his feathers, and exhibited evident signs of contentment. The plan was quite successful. The male recovered his health, regained his spirits, and lived for several years. Did this bird imagine that the image reflected in the glass was the shadow of her he mourned? or was it only a diversion from solitude?

There exists in India a gigantic crane (Ardea argila) which shares with the jackals the office of scavenger of the public roads.

Even the drake, whose nasal and discordant voice denotes but little intelligence, has on some occasions shown great sagacity. The following has been related by one of our most eminent naturalists, who heard it from a person worthy of credit:-

"A young lady was sitting in a room adjoining a poultryyard, where chickens, ducks, and geese were disporting themselves. A drake came in, approached the lady, seized the bottom of her dress with his beak, and pulled it vigorously 


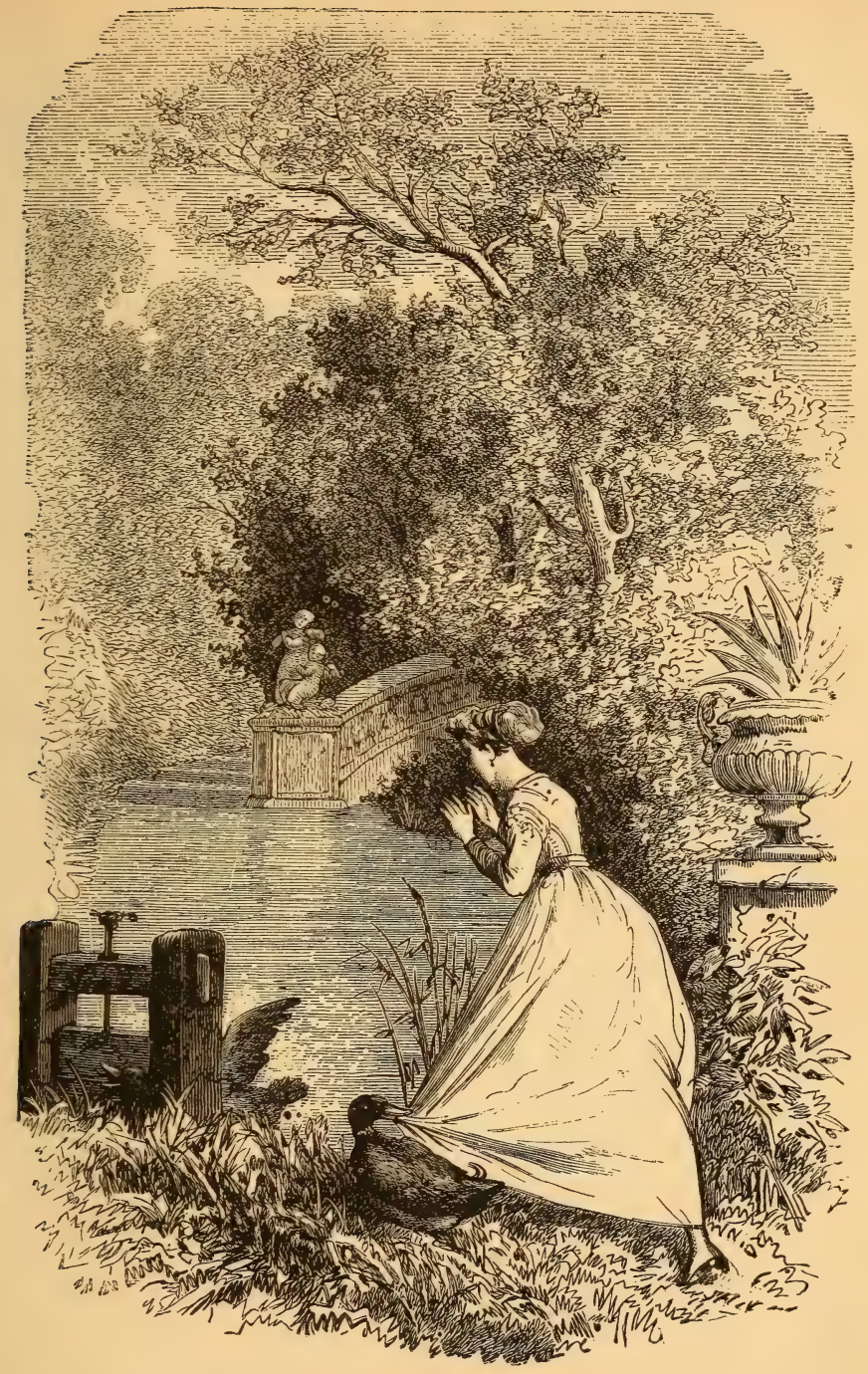

THE DRAKE LEADING THE LADY TO THE RESCUE. 

Feeling startled, she repulsed him with her hand. The bird still persisted. Somewhat astonished, she paid some attention to this unaccountable pantomime, and discovered that the drake wished to drag her out of doors. She got up, he waddled out quickly before her. More and more surprised, she followed him, and he conducted her to the side of a pond where she perceived a duck with its head caught in the opening of a sluice. She hastened to release the poor creature and restored it to the drake, who, by loud quackings and beating of his wings, testified his joy at the deliverance of his companion." 


\section{THE MAMMALIA.}

WE have now reached a class of animals which, by their organisation and intelligence, approach nearest to man. The mammalia have a bony skeleton, the centre of which is the spine, to which the other organs are attached, and whence they all radiate. They possess, also, a brain, in which the hemispheres are well developed; a heart with two ventricles and two auricles; lungs for inhaling air to oxydise the blood and stimulate all the organs, the brain especially. The thoracic cavity contains the lungs and the heart, which are always separated from the abdominal cavity by a complete diaphragm.

In this class the organs of sense acquire great perfection, even in their accessory parts. For instance, the greater number of each species have distinct eyelids, an external ear, and other peculiarities which are not found amongst the oviparous animals. The mouth is furnished with fleshy lips (except the monotrematous animals*), and the body is habitually protected with a specially adapted covering.

All the mammalia have five senses, but in different degrees. Thus, one species, such as the chamois and wild goats, that live upon the mountains, have long sight, and can see better far away than near. On the contrary, the heavy races which inhabit the valleys, such as the hog and rhino-

* The Echidna, or Australian hedgehog, and the Ornithorhynchus, or water-mole of New South Wales, belong to the Monotremes. 
ceros, can see objects best when near them. Those whose eyes are too sensitive to bear the bright light of day, only go out during the night, like bats, or even hide themselves under the earth, as the armadillo and hedgehog. Those creatures which are the weakest, being on that account the more timid, are gifted with a keen sense of hearing. This enables them to avoid danger. The hare, the rabbit, the jerboa, the mouse, and other rodentia, on hearing the slightest noise, prepare for flight. The more powerful or courageous races, the lion, tiger, cat, and lynx, whose sight is keen, even at night, have short ears and weak hearing, the strength of one sense generally compensating for the weakness of others.

With the carnivora the sense of taste becomes an eager, sanguinary appetite, while the herbivorous animals require a delicacy of taste to enable them to distinguish the nourishing plant from that which would poison them. "Thus," says Virey, "nature adapts the constitution of each individual to its destiny on earth. In depriving the armadillo and pangolins of teeth, she covers them with a coat of mail or scales. In making the hedgehog and porcupine weak and defenceless, she enables them to raise at pleasure a forest of sharp quills, and these animals have only to roll themselves up and become a prickly ball, which is quite impregnable. In denying to the herbivorous animals strong teeth and hooked claws, nature has armed the head of the ruminants with formidable horns; finally, she gives to the timid animals, such as the rodentia, either the industry to hide themselves in the earth, like the marmot, the rabbit, and the rat; the agility to jump from tree to tree, like the squirrel; or great quickness in running, and power to take immense leaps in fleeing from danger, as the kangaroo, which bounds along 
like a grasshopper. The llama is quite defenceless, but, if attacked, it covers its enemies with a disgusting and bitter saliva. The pole-cats, and all of that species, when pursued, throw off such execrable odours that their most ferocious enemies are obliged to give up the pursuit.

Some animals frighten their persecutor by frightful cries, like the howling monkey; others mislead their foes by a number of tricks and careful precautions, and know where to obtain safe shelter and seek obscure retreats.

The smallest species, besides being more numerous and multiplying more abundantly, are also more lively in proportion to their size than the larger animals. Before an elephant or a whale could turn round, a dormouse or a mouse would have made a hundred movements, the smallness of the limbs giving more unity and more control over the body; the shorter muscles contract more easily, and each movement is more rapid than amongst larger creatures. The mammalia form the intermediate class by which the other animals approach to us, and by which the inferior species are grouped around man. In fact, the family of the apes seems to come very near to the human race. On the other hand, the bats, the flying squirrel of Siberia, and other like species, appear to link the birds to the mammalia; while the armadillo and the pangolin, quadrupeds covered either with a cuirass or with scales placed one over the other, seem related to the reptile, such as tortoises and lizards. The amphibious mammalia, such as the seal, sea-cow, and other cetacea, which apparently partake of the nature of fishes, are linked to the large and numerous classes of aquatic animals.

"Thus," says Virey, "the mammalia form the nucleus round which are grouped the different superior classes of 
the animal kingdom as being the most perfect type of creation, and the first link in the chain of animated sature next to man. Let us compare the various other classes with the mammalia. The bird, inhabitant of the air, has received a temperament warm and lively, delicate and sensitive; always gay, full of fire and inconstancy, like the variable region he traverses. The fishes again, the cold creatures of the waters, are more apathetic, and occupy themselves chiefly with material wants; their scaly covering seems to steel them against gentle impressions, and hinder them from feeling acutely, or bringing their intelligence to anything like perfection. The quadrupeds, on the contrary, existing in a medium state, equally below the airy heights, as above the deep abyss of the waters-sharing with man the possession and sovereignty of the earth-seem to hold the middle place between two extremes. They have neither the ardour nor petulance of the bird, the lower sensibility of the fish, nor the apathy of the reptile; but, living as they do on a dry and firm soil, their nature has received more consistency, and their frame more solidity. The locomotion of the quadruped has not the rapidity of flight, nor the nimbleness of swimming; but it has not the painful slowness of the tortoise and other reptiles.

All the series of these mammalia represent a long succession of inferior structures below that of man. The monkey, considered either with regard to his external form or internal organisation, seems but a man degenerated. Skeleton, members, muscles, veins, nerves, brain, stomach, and principal viscera resemble ours almost entirey, not only in general structure, but in the ramifications of the lesser vessels. In comparison with us it appears an imperfectly formed being, although it is perfect as regards its own species. 
The same scale of graduated inferiority is observed in descending from the monkey to the bat; from the latter to sloth, to the carnivora, and through all the series.

The smaller the extent of the brain, especially the hemispheres, and the fewer the number of its circumvolutions, the more brutal or more animal do we find the creature. In fact, in the monkey itself, and the quadrupeds with long snouts, which bend towards the earth, everything tends to the growth of the appetites and the development of the senses. They think only of satisfying their physical wants. Of all animals the quadrupeds are the most capable of understanding us; not only on account of their organisation, but also because they are more susceptible of being domesticated. The bird has less relationship with us; for, whatever familiarity or intelligence may be attributed to the parrot or tame canary, the qualities of the dog, the beaver, and the elephant always surpass those of the most clever birds. The more closely a well organised animal approaches to us, the more it can comprehend us, and we can more easily, aid in developing its intelligence. This is especially the case with the mammalia.

Nevertheless, the influence of man upon the domestication of animals is limited by their fitness for sociability. There is not a single domesticated species which does not, naturally, live in society. Of all the solitary species, there is not a single one which has become domesticated; and sociability does not in the least depend on their intelligence, for the sheep lives in companionship, while the lion, fox, and becr live solitarily. Neither does it depend on habit; for the long continuance of the young ones with their parents does not produce it. The bear cherishes its young ones with as much tenderness and for as long a time 


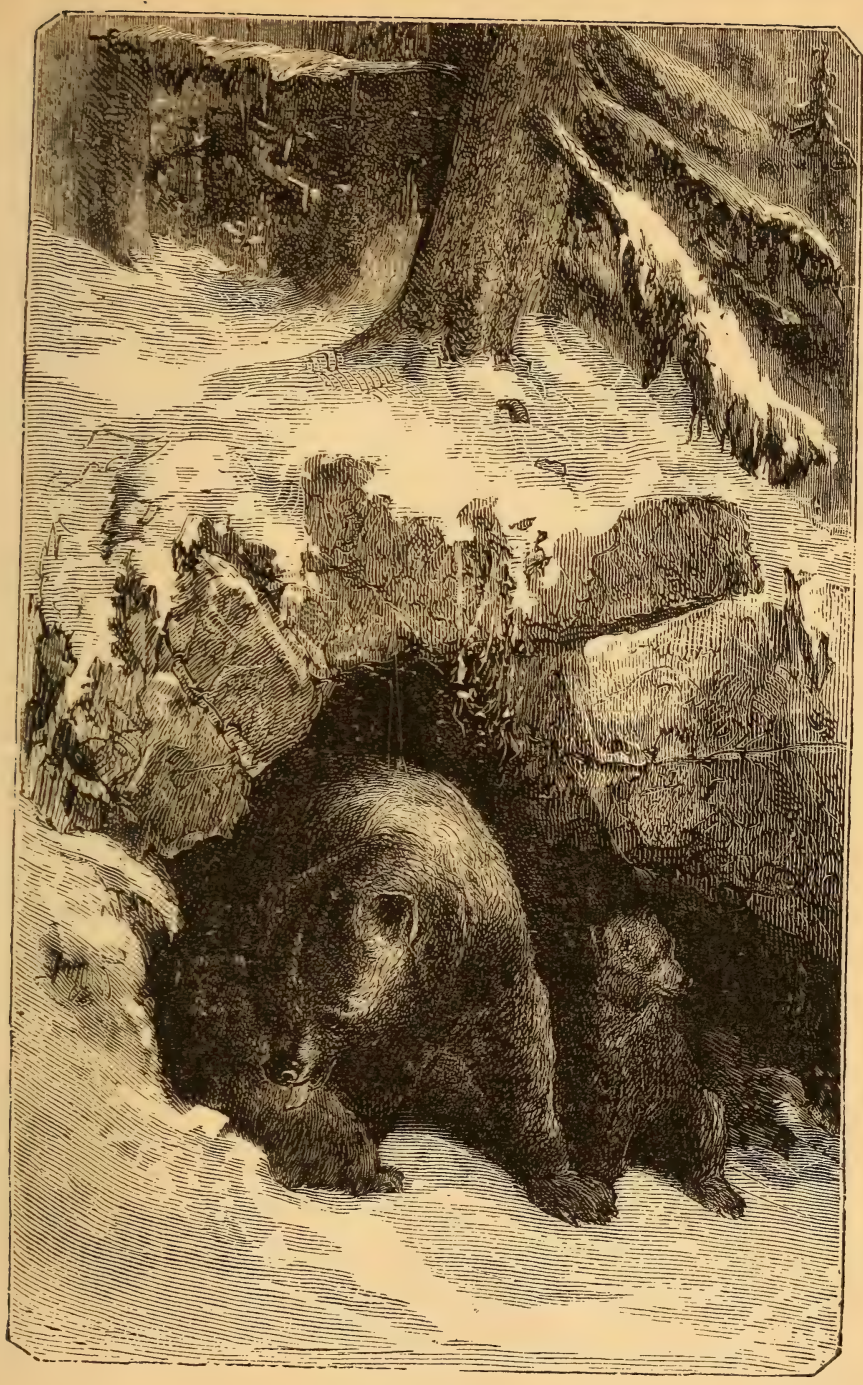

THE BEAR TENDING HER YOUNG. 

as the dog, and yet the bear is amongst the most solitary animals.

Frederic Cuvier has observed three distinct conditions amongst animals:-The solitary species, such as cats, martens, bears, and hyenas; those which live in families, such as wolves, roebucks, \&c.; those which live in societies, such as beavers, elephants, monkeys, dogs, seals, \&c.

Cuvier has devoted himself to the study of these societies. He follows the progress of the animal, which, born in the midst of the flock, is there developed, and which, at each epoch of its life, learns from all which surrounds it to place its new existence in harmony with that of the old ones. The feebleness of the young animals is the cause of their obedience to the old, which possess strength; and the habit of obeying once adopted by the young, is the reason why the power still remains with the most aged, although he has become in turn the most feeble. Whenever a society is under the direction of a chief, that chief is nearly always the most aged of the troop. Mons. Flourens thinks that this order may, perhaps, be disturbed by violent passions. If this be the case, the authority passes to another; and, having commenced anew by reason of strength, they preserve the same by habit. There are, therefore, amongst the mammalia species which form real societies; and it is from these alone that man takes all domesticated animals. The horse becomes, by domestication, the companion of man; and of all animals of his species is the most naturally so.

The sheep, which we have reared, follows us, but he also follows the flock, in the midst of which he was born. According to Cuvier, he looks upon man as the leader of the flock. Man, says M. Flourens, is to the animals only a member of their society ; all his art is reduced to making 
himself acceptable to them as an associate; for, let him once become their associate, he soon becomes their chief, being superior to them in intelligence. Man does not, therefore, change the natural state of these animals, as Buffon says; on the contrary, he profits by it. In other terms, having found the animals sociable, he renders them domesticated; and thus domestication is not a singular case, but a simple modification, a natural consequence, of animal sociability. Nearly all our domestic animals are naturally sociable. The ox, goat, pig, dog, rabbit, \&c., live, by nature, in society ; that is, in herds or flocks.

The cat is not really a domesticated animal-it is not subdued, only tamed; in the same way the bear, lion, and tiger even might be tamed, but not domesticated. Man's influence will make a sociable animal domesticated, but a solitary animal he can only tame.

M. Flourens attributes the domesticity of animals to their social instincts. But whence comes this instinct? By what is it determined? Evidently by the organisation. Animals which have hitherto resisted sociability are manifestly those in which animalism is most developed, and which are better armed to insure their existence and defend their life. Man may be able to train the seal for fishing, but the greater number of the marsupialia, edentata, and rodentia have too little intelligence for him to derive much advantage from it. Let us here recall the fact that amongst the mammalia the degree of intelligence is in proportion to the development of the brain hemispheres. In the rodentia the hemispheres have no circumvolutions; those of the ruminants have; those of the pachydermata have more, and thus they go on increasing, in the carnivora, monkeys, and ourang-outans. The hemispheres of the rodentia have but 
one lobe, those of the ruminants have two, those of the pachydermata have three, and still higher developed are those of the carnivora, monkeys, ourang-outan, and man.

With regard to the size of the brain hemispheres before and behind, we must note that in the rodentia they do not reach the four little elevations called the pyramids, and olivary bodies; in the ruminants they cover them, in the pachydermata they reach to the hinder part of the brain, they extend over all that part of the brain in the ourangoutan, and in man they go beyond it.

In making these remarks on the organ of intelligence, let us not forget that all the other functions re-act on the brain. We will now commence the study of intelligence in the mammalia with those which possess a brain but little developed. Then we will proceed successively to those whose intellectual faculties approach nearest to man. 


\section{CETACEA.}

WHALES - MANATEES - DUGONGS - NARWHALS - SEALS WALRUS-DOLPHINS-PORPOISES.

THE Cetacea comprehend the whales and all animals allied to them by habits and structure. Can intelligence be expected among such creatures? Undoubtedly; and few indeed are the animals which have not faculties perfectly adapted to their modes of life. We may advance a step further, and say that not even one living creature is found unfurnished with faculties suited to its wants : its gifts correspond to its requirements. The wider our knowledge of animal nature becomes, the more deeply are we impressed with the conviction that mind, in various degrees, belongs to every animal. We may certainly, then, expect to find manifestations of this power in the families of the order Cetacea.* Of all marine creatures these are most allied to ourselves. This will startle those only who are not acquainted with the structure of the common whale or seal; their warm blood, circulating system, breathing by lungs, and the nourishment of the young with the mother's milk, place an impassable barrier between them and the other inhabitants of the deep. The same peculiarities place them in that great class, the mammalia, at the head of which man stands as the divinely commissioned chief of the whole animal world.

* A word formed from the Latin Cete, which is from the Greek кі̃rog, a whale, or large fish. 
Let no proud son of Adam feel it a degradation to be thus associated with whales. We cannot escape from those great laws of structure which the Creator has been pleased to observe when $\mathrm{He}$ designed the higher forms of animal life, placed far above the other members of the great animal kingdom. We need not shrink from noting either the physical resemblances or mental qualities which belong to all.

The huge size of the whales, perhaps, tends to fix our attention exclusively on their massive forms and giant strength. A creature measuring seventy feet in length, the main artery (aorta) of whose heart is a foot in diameter, and which at every beat of the organ ejects twelve gallons of blood into the circulating system, is naturally regarded as a mere titanic mass of animal life. But these giants of the deep possess affections and degrees of intelligence not unworthy of our consideration. They are social animals, and thus possess one marked characteristic of intelligent creatures. Sometimes five hundred or more spermaceti whales are found moving under the guidance of old chiefs. The fishermen call these associations "schools," and the leaders "schoolmasters ;" terms not quite inappropriate when it is borne in mind that the young whales form the majority of such groups. Some of these "schools" are wholly composed of females, guarded by two or three sagacious "schoolmasters," whose office can hardly be a sinecure. Others consist of the young animals carefully tended by their mothers. Troops, forty or fifty in number, will often follow a ship for miles if not attacked.

These social affections in the whale are most strongly shown in the care and attention bestowed upon the young. All who have seen the mother whale giving suck to her one or two "infants," and have watched the young playing 
round the parent, need no proof that the great law of love acts strongly in these huge children of the deep. The affection of the common Greenland whale for her young is often used to accomplish her destruction. If the young one can be struck with the harpoon, the fishermen know that the mother will encounter every peril in the attempt to extricate her child. Sometimes her fury and desperation have exposed the assailants to the most imminent danger. Captain Scoresby, who witnessed the capture of so many whales, gives several accounts of the determined courage shown by the mother whales in the attempt to rescue their young. Some caught "the baby" by their flippers or fins, and tried to drag it away, and lost their own lives in the incessant attempts to save the harpooned little one. In all these struggles the whale evidently understood the nature of the peril and the object of her human foes. The mode in which the agonised whale endeavours to carry off the young, has all the appearance of an intelligent act. The "infant" is taken under the swimming paw or fin of the mother, and pressed closely by the fin-hand to the parent's side, much in the same manner as a child is sometimes carried for a short distance under a woman's arm. The strong pressure of the paw, nine feet long and five wide, is quite sufficient to drag oft the young with a hundred yards of rope and harpoon attached to the body.

Even in the mode of feeding her young, the whale shows a thorough sense of the little creature's wants, and adapts her position in the water to its requirements. When the young one wishes to take the breast, the mother floats on her side, and thus enables the "child" to feed with ease. The whale's milk is said to be much richer than that of the cow, so that the infant cetacean is really well cared for in the matter of food. 
The management of the singular "whalebone" trap, with which the mouth of the Greenland whale is furnished, might seem to require some skill in the animal; probably, however, the opening and closing of so many hundred plates of baleen to let in the water and retain the "whale's food,"* may be as involuntary as the action of the human epiglottis in closing the opening to the windpipe, when the food passes over.

The energy which whales evince when pierced by the harpoon must ever prevent them from being classed among the "sluggish" animals. Scoresby records a case of one of these animals descending for a mile into the ocean's depths at one plunge, dragging after it that enormous length of rope. Even, after such a dive, the furious plunges of the whale would have probably drawn the large boat under the water also, had not a fresh crew arrived with more rope. The nervous and muscular energy required for so grand a plunge may be estimated from the fact that the pressure of water on the body of such an animal at that depth must have exceeded 210,000 tons.

The other members of the cetacean order show an intelligence and energy equal, if not even superior, to that of the whale. Two genera are vegetable feeders, the manatees and dugongs. The former obtain their name from the Latin manus, a hand, on account of the hand-like form of the flippers, in which the bones of the four fingers can be distinctly traced. These manatees having the bosoms placed high on the breast, and the mouth surrounded with hair, when seen swimming with head above water and baby at the breast, not unnaturally originated the poetic stories of mer-

* The Clio Borealis, a small mollusc which swarms in the Northern Ocean. 
maids and mer-men. Thus the "woman-fish," and "the bearded man of the sea," gave birth to many a wondrous tale of old romance. The manatee excels, if possible, the common whale in affection and care for the young, which are said to be placed in the centre of the troop on the approach of danger.

The dugongs (Halicore),* another genus of vegetablefeeding cetaceans, are just as remarkable as the manatees for the intelligence manifested in the care of the young. Indeed, Professor Owen himself has not given more attention to the structure of the dugong's teeth than these inoffensive people of the sea devote to the bringing up of their families. On this account the half-civilized tribes of the South Paciric Ocean regard the dugongs as the very model of maternal tenderness. Does not this sound like a delicate bit of irony on uncultured humanity? A cetacean is selected as the type of motherly love!

The narwhal, or unicorn-whale, may show less intelligence than some other members of the order, but this animal appears to be a clever harpooner, piercing fishes with its seven feet long horn or tusk before swallowing them. To draw into its smooth, toothless mouth, a strong and living fish, would be impossible, and therefore the narwhal is furnished with a long spear-like tusk with which to kill its prey. This animal is also thought to find another use for this weapon. When the shallow arctic waters, in which the narwhal delights to live, are frozen over, the creature must either move out into the deeper and unfrozen seas, or pierce the ice in the shoal waters in order to obtain breathing holes. The latter is the course often adopted; the solid

* This compound Greek word signifies mer-maid, viz., maid of the sea. 
ivory tusks being well fitted to split up any but the thickest ice. Curiosity is sometimes playfully imputed to Eve's daughters as a fault, but this quality is, nevertheless, a mark of intelligence. The narwhals possess it in a high degree. The sight of a ship attracts the amazed herd, which swims round her again and again, as if endeavouring to comprehend the nature of the mass before them. The tusk of the narwhal was often placed in old museums as a true unicorn's horn, but for this misrepresentation our simpleminded cetacean is not responsible.

The seals must not be passed over when considering the intelligence of the order to which they belong. Some class them amongst the quadrupeds, but the less we refer to the lour feet of the seal the better for our own repute. The skill, acuteness, and memory of seals will be admitted by all those who are most familiar with them. The amazing speed with which they dodge a shot, plunging at the moment of the flash, is well known to hunters. The activity and courage displayed by them in hunting the swift salmon has moved the highest indignation of many a fisherman. Sir Walter Scott was well aware of the cunning and courage of the seal when representing in "The Antiquary" the laughable overthrow of $\mathrm{M}$ 'Intyre by the enraged animal he had endeavoured to capture. Many readers will recollect how the captain was prostrated, and the antiquary's stick carried off by the victorious "phoca." The seal, however, is not usually the assailant of man, save in defence of itself or young ones. Then, indeed, it will make a good fight, for which none can blame the creature. The animal has often been tamed so far as to visit, at intervals, the cottage of its benefactor, and even to apply for shelter at the door during those terrible tempests which compel the seal to seek a 
shelter from their fury; at such times the storm-beaten animal utters a wailing cry, so like that of an infant as to deceive the fishermen's wives. Of course, these cases of seal domestication are rare, but even these few are sufficient to indicate the capacities of the creature. Some have even been taught to obey words of command, to stand up, lie down, give a paw like a dog, and to perform other feats indicating the possession of superior teachable capacities. All their senses are highly developed. The eye is remarkably keen, and the seal can shorten the axis of vision by bringing the crystalline lens nearer to the back of the eye when the animal is on the land. These cetacea are also quick of hearing, and appear to possess an acute sense of smell. With these endowments it may easily be understood that all the species of this family can hunt the most active fish, as surely as trained hounds can pursue the fox or the stag. All are characterised by intense affection for their young. The great elephant seal (Macrorhinus),* and the species called the "sea lion," will lose their lives in defence of the "cubs" if unable to carry them off. The formidable walrus seals, armed with mighty tusks, though less intelligent than the common seals, show a high degree of energy when attacked, even attempting to rescue their wounded companions, and tearing the oars with their mouths from the hands of the sailors in the assaulting boats.

The dolphins, called also "white whales," are noted for their social habits, living in large societies, which swim round ships and boats with surprising speed. The elegant shape, graceful motions, whitish colour, and the singular smallness of their blue eyes, cause even the utilitarian whalers to

* The word denotes long nose, the allusion being to the trunk on the head of this seal. 
regard these cetacea as the beauties of the sea. The intelligence of the dolphin calls for no special remark, as they possess the same amount of energy, and manifest a like care for the young, which distinguish the other genera of the order. Why the dolphin should have been so far honoured in old times as to give the title of Dauphin* to the elder sons of the kings of France, and to bestow a name on one of the provinces of that country, is not very evident. As the broom plant in the cap of the Earl of Anjou may have originated the surname plantagenet, so the dolphin symbol on the helmet of Guy, Count of Vienne, may be the source of the once famous titie of Dauphin. If the historian is thus reminded of the dolphin, the animal is also fated to live in the records of literature and the annals of astronomy. The scholar will not forget the "delphin classics," and the constellation "Delphinus" compels even science to remember a cetacean so strangely thrown amongst the stars.

The porpoise is, probably, equal to the dolphin in intelligence, though it has failed to gain the "threefold honours" of the latter. It is devoted to its young, an energetic and keen hunter of fish, eminently social, and distinguished for courage.

Looking over the various families of the cetacea, who can say that any one is deficient in the faculties required by the peculiar structure and wants of each? But it they possess the affections, courage, energy, and skill suited to their modes of life, we must then place them amongst the intelligent though lower orders of the mammalia.

* French for dolphin; the Latin is delphinus. 


\section{THE MARSUPIALIA.}

FEw readers need to be informed that a certain number of animals are thus named from the pouch (Latin, marsupium) in which the immature young are received after birth. The opossums, flying squirrels, and kangaroos are well-known animals of this order. This remarkable section of the great mammalia class seems, at the first view, most unlikely to furnish examples of animal intelligence. But what is our test of this faculty in what are called brute creatures? Do we expect them to imitate our works, to act in our modes, and, in a word, to exhibit something like human reason? This is surely not very rational in us. Why should animals differing in structure from ourselves be expected to act like man? The true question seems to be this : Do those creatures adapt their special organs and capacities to the various circumstances in which they are placed? Do they use their peculiar tools in the best possible way? If the answer must be in the affirmative, then how can the inference that the lower animals possess an intelligence suited to their modes of life be avoided? Probably few would deny this general statement, yet many persons seem almost terrified at the notion of a dog reasoning or an elephant showing judgment or prudence. The more our knowledge of the animal kingdom is extended, the more abundant do the proofs of a widely diffused intelligence in all orders, genera, and species become. We may hide this great fact under the word instinct, but if there are human instincts united with a high understanding in man, why 
should we shrink from admitting that special instincts may be combined with a lower order of intelligence in such creatures as the kangaroo and opossum?

We pass over, in this place, the peculiarities presented by the singular pouch of the marsupial animals, and limit our observations to the manifestations of intelligence given by the various genera. No reader will expect from these creatures the sagacity of the dog or the capacity of the horse. The talents of the marsupials are suited to their wants, and these are not very various or numerous. The kangaroo has been called "stupid," and, doubtless, when compared with the imitative ape or the active tiger, the animal appears somewhat sheepish. The keepers of kangaroos have thought that these creatures fail to recognise their attendants, and attribute this to feeble perceptions or want of memory. It is, however, impossible for these men to know what view the imprisoned kangaroo takes of its gaolers: its sedateness is no proof of dulness. The brain is certainly deficient in that peculiar band of nervous matter called the corpus callosum, which connects, in other mammalia, the two hemispheres of the cerebrum, or outer brain. On this account, Professor Owen has placed all the marsupials in an order named Tymcephala.* Whatever intelligence the kangaroo has must be inferred from its actions rather than from unexplained peculiarities of the brain. The creature, when first seen by Captain Cook and his party, showed itself perfectly able to look after its own interests and provide for its own safety. Those who, judging from its sheepish air, thought dogs would soon capture such an animal, were amazed at the activity and energy displayed by the hunted creature. The speed of greyhounds was sorely

- Separated brains. 
tried by an animal which leaped over obstacles eight feet high. This style of going across a country by a succession of the most surprising leaps, soon made both dogs and men respect the racing powers of the kangaroo. Even should the animal be brought to bay, it employs its natural weapons of defence with a skill and determination admitting of no dispute. The hind feet of the kangaroo are armed with powerful claws, and the tail is so thick and powerful that the creature can employ the organ as a strong prop to support the body in an erect position. Now judge of the intelligence with which these tools and weapons are used. The animal stands at bay, the dogs rush on; but, see! the kangaroo raises one of its powerful hind feet, and, with a sweep of the limb, nearly tears open the body of the foremost dog by means of the knife-like claw. The animal is perfectly aware of the power of its armed foot; and if the creature had the reasoning powers of a Newton, it could not use the weapon more efficiently. This does not arise from any natural tendency to strike at objects with the hind foot. The animal is naturally timid and peaceful, showing its energies and powers of resistance only when driven to fight in self-defence. The value of the tail as a helper in the conflict is felt by the kangaroo. When the hind foot is raised to strike the foe, the animal would be supported on one foot only, for the front legs are too short to give any aid in steadying the creature's body when it strikes at the enemy. Without the support of the tail the animal must certainly fall, and the dogs would then have an easy victory. But when the hind foot is raised to deal the blow, the strong and muscular tail is so placed as to prop up in a most effectual manner this fighting "Australian sheep." There is nothing "stupid" in this use of the natural organs. 
The management of the young by the kangaroo mother proves the possession not only of affection but of intelligence. The young one, when born, is only about an inch long, and is in all respects an undeveloped animal. The mother seems to be perfectly aware of this, carefully places the infant in the pouch, and guides it to her breast, to which the little thing immediately clings. Thus enclosed in this singular living bag, the infant kangaroo is carefully tended by the mother for about nine months. By that time the young one has grown into a fine, active baby, weighing about twelve pounds, and able to get in and out of the pouch without the parent's help. When experimenting naturalists have gently separated the young from the nipple, the mother has found the means of replacing the little creature's mouth on the source of nourishment. The young one is for some time too feeble to crawl up from the bottom of the pouch to the nipple, and must be placed there by the soft fleshy lips of the mother. She has been seen on these occasions to open the pouch with her fore-paws, and thrust in her long slender head, doubtless with the object of properly fixing the young one. It will be seen, therefore, that the kangaroo has an intelligence which guides the animal to use well its means of defence, and to adapt itself to the peculiar circumstances in which naturalists have sometimes placed captured individuals. Sydney Smith's humorous description of the kangaroo has, of course, a slight touch of exaggeration: "A monstrous animal, as tall as a grenadier, with the head of a rabbit, a tail as big as a bed post, hopping along at the rate of five hops to a mile, with three or four young kangaroos looking out of the pouch to see what is passing."

The words "as tall as a grenadier" may pass, as the 
animal's body equals in size that of a sheep, and has been known to weigh about 140 lbs. The "five hops to a mile" are, of course, beyond the powers of the most energetic of kangaroos, and "the four young looking out of the pouch" may be reduced to one, that being the usual number of the family.

Another marsupial animal, the opossum, is not much larger than a common cat, but was called by some of the earlier American travellers "the wonder of all the land animals," and one sums up his description by the pithy remark, "If a cat has nine lives, this creature surely has nineteen." The reason assigned for this statement was that an opossum would live though "every bone in its skin" were broken. The reason given has one defect : it is not true. The ingenuity with which the Virginian opossum avoids the snares and baffles the stratagems of the hunter, has long made it famous in the annals of forest life. It may be "stupid" when a prisoner, but there is no doubt of the acuteness of the wild animal. It is positively stated that a captured opossum will feign death, remaining perfectly passive, and to all appearance unconscious, in spite of the pinches, kicks, and buffetings of the sceptical hunters. But no sooner is the animal left on the ground alone, the hunters hiding themselves behind trees, than the cool and cunning creature darts off to the nearest tree, taking refuge in the thick foliage of the loftiest branches. Was this the result of mere nervous dread, producing inability to move, or of a calculation by the animal that perfect quietude would secure it from harm? The former can hardly be the case, as the moment the opossum finds itself alone it darts off with the utmost speed. On the other hand, it does seem almost beyond belief that a wild animal should have such 
command over its impulses as the theory of "pretending to be dead" supposes. There is, however, abundant evidence to lead us to the conclusion that many animals have exhibited this wonderful degree of self-control, and there is, therefore, no sufficient a priori argument against its possession by the "'cute opossum." Such questions must ever be decided by facts, independently of speculations and prejudices.

The flying squirrel, or petaurus, is another of the "stupid" marsupialia, which shows, in all its movements, that it knows how to make the very best use of its natural organs. This, all readers will bear in mind, is the true test of animal intelligence. Now, we all know that the petaurus does not fly, but only uses, in a most effective manner, the loose skin which extends along the sides from the fore to the hind legs. When the active creature leaps from tree to tree in the gloom of the evening, the action of the extended limbs causes the folds of the skin to expand like a parachute, by which the "flying squirrel" is able to support itself in the air, when making its extraordinary bounds from one distant branch to another. The due calculation of distances, the proper expansion of the extensible skin, according to the support required, and the adaptation of the parachute power to sudden emergencies, cannot be reasonably attributed to mere animal impulse.

Thus we find, even in these lower forms of mammalian life, those exhibitions of energy and skilful use of natural tools which indicate an intelligence observant of circum. stances and qualified to use them rightly. 


\section{THE EDENTATA.}

\section{ANT-EATER-SLOTH-ECHIDNA-ARMADILLO-AARD-VARK- ORNITHORHYNCHUS.}

THIS order of animals is thus named from the absence of the front teeth in the jaw. This is no defect in these creatures, but an adaptation of structure to their mode of life. They do not rank high in intelligence, but we may find undoubted marks of prudence and acuteness in some of the genera. Readers will probably remember that the gigantic megatherium* which inhabited the ancient earth is placed in this singular order by the scientific students of ancient living forms. The edentata are thus connected with the primeval quadrupeds which roamed over the plains of earth when there was " not a man to till the ground."

The great ant-eater (Myrmecophaga jubata), about the size of a large dog, is often described as most "stupid," the chief evidence being that the animal cannot run very fast, the peculiar form of the feet preventing rapid motion. But as the creature is not intended to be a racer, it is as unreasonable to call it dull on this ground as it would be to term men fools because they are unable to fly. Let us watch the mode in which the ant-eater obtains a dinner, and then say how, with its peculiar structure, it could act more intelligently. The reader will bear in mind that this animal, sometimes called the ant-bear, has no teeth, but possesses a long muzzle, an extensible tongue, and powerful claws.

* Great animal. 
Now, in what manner shall the animal obtain its food? It cannot masticate vegetables; to tear and rend fleshy substances is still more out of the question. But in the wide plains of South America the white ants swarm, and erect their mound-like nests in hundreds on the swampy savannahs. The ant-eater knows that these hills contain his only possible food; but how shall he capture enough of such insects to make a dinner for himself? He has his weapons, and he knows how to use them. The animal approaches an ant-hill ; the mud-walls of the insect nest are baked by the tropical sun into a dry and stone-like mass; but the anteater quickly scratches a hole in the side with his powerful and hook-like claws. When the breach is made, the enraged ants pour out to inflict punishment on the invader of their home. This is precisely what the ant-eater wishes. No sooner do the irritated insects swarm out beyond the opening, than the cunning assailant lengthens his elastic tongue, and, projecting it far beyond the end of his mouth, draws the organ over the thick crowds of ants. Hundreds stick to the glutinous tongue, and are instantly swallowed. The clever operation is repeated again and again, until the ant-eater is satisfied with his dinner, when he soberly retreats to his hole, and goes to sleep. The reader will not, we think, be able to point out any blunder in the whole of this proceeding. The suitable food is sought in the proper place, and it is obtained in the only way possible. The ant-eater must be aware that his tongue is covered with a gummy fluid which not only takes up the ants, but protects the organ from the bites of the insects. Were time allowed to the ants, they would soon extricate themselves, or at least pierce through the thin glutinous coating of the tongue. Their foe seems perfectly aware of this, and accordingly 
retracts his elastic organ with such rapidity that in the space of one second it is twice drawn into the mouth covered with the ants. We must admit that the ant-eater uses his special tools well-that is to say, with intelligence.

The ant-eaters are the only true edentata, not having any teeth in their long tube-like mouth, while other genera of the order have both molar and canine teeth.

The echidna, or Australian hedgehog, captures the ants with its elongated tongue in the same way as the ant-eater. The singularly clever manner in which this little animal employs its tongue to sweep insects into a heap, and then collect them on the glutinous organ, may well suggest high notions of its intelligence. This spine-covered edentata is, however, but little known, and further knowledge of its peculiar habits are necessary before we can form a definite judgment of its character.

The sloth, or ai, another genus of the edentate order, received its common English name from those who were ignorant of its habits. When seen upon the ground, it is indeed a "sloth;" and Buffon may well be pardoned for the doleful ditty in which he bemoans the woes of the sloth, though he himself would not, possibly, have appeared to great advantage had he been suspended in the air or submerged in the Seine. Yet this would be almost as natural to man as the ground to the sloth. Those who have seen the creature in the forest during a tempest of wind, as the animal springs from branch to branch and tree to tree with all the activity of a squirrel, will admire the energy and skill with which it clings, back dowenwards, to the rocking branches. To Mr. Waterton is due the honour of clearly describing the natural habits of the sloth, which some naturalists had almost regarded as a sad specimen of defective organisation. Here 
is another instance of our tendency to hasty generalisation respecting animals. We see a creature under artificial conditions ; it then appears puzzled and dull, and we cry, "How stupid!" Further knowledge shows the supposed dullard to be an energetic and sprightly being. This lesson will have to be repeated in a thousand forms before we shall generally become conscious of the wide range of animal intelligence. No museums, however rich in collections, can give much instruction on this point; the living animals must be seen and watched. Even zoological gardens will fail to give the full lesson; it is in their natural haunts and unrestrained modes of life that the intelligence of animals is manifested. Hence the great importance attached to the observations of travelling naturalists, who alone have the opportunities of seeing animal life in all the varieties of native freedom. England and America boast of many such, whose labours are destined to clear away many an error which hides from our view the fulness and variety of animal intelligence. Had zoologists not advanced beyond the facts known to Buffon, we should have been still repeating the story of the sloth's stupidity or unhappy organisation. Even now we only see enough to prove that the old notions are wrong, and we await further knowledge respecting a quadruped fitted to live in trees, and sleeping with back downwards.

The armadillo is, of course, too rarely examined in this country for us to become at all familiar with its habits. The animal is by no means the listless creature which a hasty glance might lead us to suppose. Its skill and energy in burrowing are truly remarkable, the hole being mined with a rapidity which might excite the envy of an engineer. In order to obtain some grain lying on the ground, under a cover, an armadillo drove his trench beneath the ground so 
as to come exactly under the spot where the coveted food was lying. The subterranean tunnel borer did not deviate an inch to the right or to the left. Here was a special plan devised and carried out with a definite purpose in view. One species of armadillo (the Mataco), when attacked, rolls itself up so firmly as to defy all attempts to pierce the body. Its patience is unconquerable, and it will preserve its rounded shape until convinced that the danger has passed.

The aard-vark (Orycteropus), * or "earth-pig" of Cape Colony, is allied both to the armadilloes and the ant-eaters, resembling the former in structure, and the latter in its mode of procuring ants for food. In the silence of night the aard-vark bores into the sides of the huge ant-hill, and, thrusting its tongue into the hole, receives upon the extended member successive swarms of ants.

We must not omit to notice here that singular animal known as the duck-bill, or water-mole, of Australia ; and in

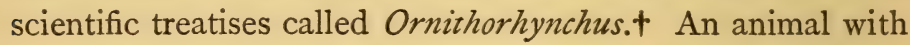
the mouth of a duck, the body of a quadruped, and distinguished by some extraordinary peculiarities of structure, might well occupy us in describing its marvellous organisation. But we have mentioned the creature in this place simply with the view of calling attention to the fact that this singular animal is not without intelligence. It is quick of eye and ear, and cautious must the rifleman be who hopes to shoot this "mole" as it swims across a river. The animal rivals our mole in engineering skill, making a tunnel above ten feet long in the bank of a stream, and forming a warm nest at the end of the passage. The "combing

* Aard-vark is Dutch for earth-pig; Orycteropus is Greek for a digging foot.

+ Bird-beaked. 
of the fur" shows, in no small degree, the ingenuity of the animal. The hind foot is provided with a claw, at first supposed to be a dangerous weapon, but now ascertained to form a part of the creature's toilet apparatus. The claw is really a comb, with which the hairs of the fur are neatly smoothed and separated by the duck-bill, which seems especially anxious to keep its coat in good condition.

We now conclude this chapter by asking the reader to point out any one of the above-named edentata which can be called stupid. Each uses its natural weapons in the best way. But is not this intelligence? 


\section{THE RODENTIA.}

THE rodentia, such as hares, rabbits, and rats, have two long cutting front teeth to each jaw, and generally three or four molar teeth. A vacant space, similar to that in the lower jaw of a horse, separates their incisors from their molars. The number of genera of this order is very considerable, and not less than four hundred species are known; amongst them are the squirrels, marmots, beavers, the field-mouse (to which the musk-rat of India belongs), the rats, the jerboa or jumping rat, the Columbian rats, which have the eyes hidden under the skin, the moles, porcupines, agouti, the Indian hog, and the cavey.

Hares and rabbits are also rodentia; but they differ from those already named, inasmuch as they have at the back of their upper incisors a pair of teeth smaller and differently formed. This characteristic is found amongst the lagomys, or "calling hare," a small rodent of Alpine regions now unknown in Western Europe, but which was found here during the first part of the tertiary geological period.

There are found in the neighbourhood of Paris fossil remains of these rodents, with those of the marmot and hamsters, animals no longer existing in France, but which were formerly innumerable, and lived together with certain species still remaining, such as the dormice and field-mice.

The rodentia are usually timid, and addicted to gnawing vegetable substances. They are most of them small, though 
one of the class, the Patagonian cavey, is as large as a pig. The porcupine, beaver, marmot, hare, and rabbit belong to the larger kinds. Their hind legs, and the hinder part of the body, are generally stronger than the fore part. They run and jump well, have a snout more or less curved, a mouth moderately open, and the upper lip generally cloven perpendicularly, a peculiarity very visible in the hare. Their hearing is generally keen, the length of the ears being pro. portioned to the use the animal must make of them for safety. The burrowers have very small ears; those which live on the banks of rivers or streams, and swim much, such as the beaver and water-rat, have short round ears, which move but little; the rats, mice, rabbits, and hares, animals which escape danger by flight, have, on the contrary, the ear well developed. The head is flat; the neck is generally short, and always consists of seven vertebræ.

Their eyes are placed at the sides of the head, and are more or less developed according to the habits of the animal. Thus, in rabbits, hares, pole-cats, and dormice, they are large and projecting; in rats, squirrels, and some other species, they are of a moderate size ; in the large field-mouse and mole, which pass a great part of their life under ground, they are very small; in the spalax or Columbian rat, which never leaves its subterranean abode, they are but imperfectly formed.

Their brain is much more imperfect than that of the other mammalia. From the organisation of these animals, it is easy to infer the amount of their intelligence, which is generally less than that of the ruminants, the pachydermata, carnivora, and quadrumana. One cause of the slow growth of the intellect in a certain number of rodents is the variableness of their temperature. Certain of them 
resemble reptiles in the lowering of their temperature when the weather becomes colder. Immediately the temperature begins to fall in a sensible degree, and more particularly when their food is beginning to fail, the marmots and dormice go into a torpid state; their organs scarcely act at all, but are not wholly suspended; the circulation is much enfeebled, and the respiratory combustion has lost a great portion of its intensity. A marmot which in a state of activity burns above one grain of carbon each hour for every two pounds of its weight, does not consume more than the thirtieth part of a grain when it has fallen into its winter sleep. Thus the temperature of these animals lowers very considerably. Spallanzani even maintains that a torpid marmot does not require to breathe at all, and that it could be plunged into poisonous gas and not perish. This lowering of the circulation, respiration, and temperature, necessarily produces slowness in the cerebral activity, but this phenomenon is the exception amongst the rodentia, and we shall see that intelligence is tolerably developed in these animals.

The species are mostly herbivorous, timid, and fearful, they have no means of defence, and only find safety in flight. Some whose food is of a mixed kind-both animal and vegetable-as the rats, are often very ferocious.

The strong incisor teeth of the rodents are admirably formed for the purpose of cutting through the hardest substances. These teeth are, in truth, natural chisels, so organised as always to preserve a sharp edge. The beauty of the contrivance is that the very action of this tool, instead of blunting, tends to preserve its keenness. The front part of the tooth is of enamel, the hinder section of bone. The latter part, being the softer, soon wears down 
by the friction of the teeth in cutting, thus leaving the razorlike edge of the enamel in front. So it happens that work actually sharpens instead of blunting these admirably designed cutting instruments. The most scientific edge-tool makers form their instruments on the principles of construction seen in the teeth of rodents. The skilful combination of hard and soft iron leads to the same result as the union of the enamel with bone in the teeth of these animals.

But the best chisel made by man cannot reproduce itself, whereas the cutting tools of the rodentia grow from the root upwards as the top wears away. These gnawing animals are, then, provided with first-rate tools, and we shall probably find that the workmen are qualified to use them.

The jumping power possessed by nearly all the animals of this order will be seen to arise from their peculiar organisation. The muscles and bones of the hind legs are, in general, much stronger than those of the front, and thus the mouse makes with ease those bounds which often defeat the energetic spring of the cat.

The brains of the rodentia are marked by one peculiarity. The elevated lines of nervous matter, called convolutions, which characterise the brains of man, and most of the mammalia, are almost absent in the cerebral mass of the rodents. $\mathrm{No}$ conclusion can be safely drawn from this conformation unfavourable to the intelligence of these animals. Some of them are far too acute for us to infer imbecility from the mere smoothness of the brain's surface.

It may be right to notice that animals of the rodent order were numerous in the ancient geological ages, long prior to the human period. Heaps of their bones, preserved beneath diluvial beds of earth, have been discovered in the rocks of both the Eastern and Western continents. 


\section{RATS.}

A ITACHMENT OF RATS FOR EACH OTHER.-THEIR FORESIGHT, SKILL, AND CUNNING.-THE POLISH LEGEND.INTELLIGENCE IN MICE, LEMMINGS, MARMOTS, AND JERBOAS.

Most naturalists have placed rats amongst the obnoxious animals. The rat is, however, a domestic animal, and loves human abodes, is fond of dwelling amongst the poor, and much prefers a ruined house, with its walls of mud and clay, to the palace of a king. Some writers think its habits are patriarchal, and fancy its long, white beard, prominent eyebrows, quick and penetrating eyes, and saturnine manner, give it a respectable and noble aspect!

The rat is associated with every period in the history of mankind. This animal has followed armies, and joined in great maritime expeditions, while all invading hordes have brought a particular kind of rat in their train. We can thus, in the different varieties of this creature, trace the succession of the human races established on the surface of every territory.

The brown rat appeared in England about the year 1736, but whether brought from Russia or India is disputed. It is simply a fable that it reached this country with George I. It has been sometimes called the Norway rat, but with little reason, as it is but a colonist there. This rat has now become a veritable plague to Great Britain, where it has devoured all the other kinds. The rat, like 


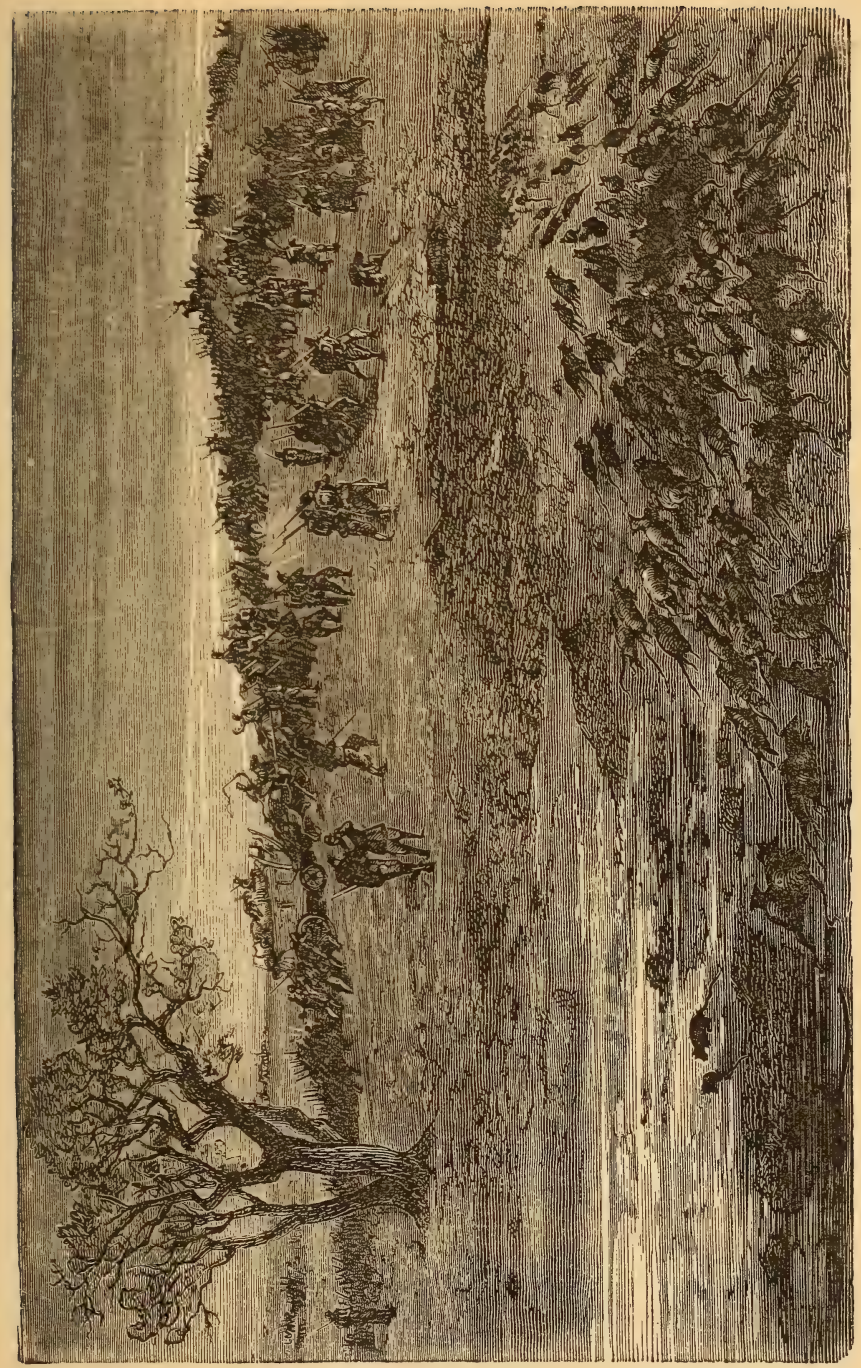

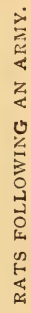



the barbarian, is sometimes a scourge, which God sends amongst civilised nations, to warn them, and punish them for their errors. According to some writers, the rat has been commissioned, more than once, with the execution of divine sentences, and occupies, on this account, an important place in the destinies of humanity.

"It was the field-mouse of Egypt," says one, "which destroyed the army of Sennacherib, by devouring all the cords of the bows and fastenings of the shields belonging to the Assyrians, during the night."

Pliny has filled an entire chapter of his eighth book, in relating the history of cities destroyed by the ravages of animals. The rat may have played an important part in these overthrows, both before and after the time of Pliny, but it rather completed the ruin than began it. The fate of the Archbishop of Mayence is narrated by some sensational writers, who describe him as dragged from his tower into the middle of the Rhine, and drowned by a horde of rats, which did not retreat until they had destroyed the name and image of this impious man from the tapestry by means of their teeth!

Notwithstanding some evidences of the rapacity of the rat and its taste for human flesh, examples are related of true attachment in these animals, not only for their own species but also towards man. The rat is not insensible to good treatment, but attaches himself to persons who feed and pet him. Prisoners especially have borne witness to this fact. Rats are also clever and intelligent workmen; they construct their dwellings with skill; the smallest are inhabited by one family only, while the larger ones contain several. Their sagacity is especially displayed in the choice of the place where they take up their abode. They build 
their houses in marshes, or by the sides of lakes and rivers, which have a wide reach, and of which the bed is shallow and the water sluggish. They choose the most elevated part of these lands for their habitations, so that the rising waters may not annoy them; if their dwelling is too low, they raise it; they also arrange it in gradations, to enable them to mount from story to story, as the water rises. When this dwelling is intended for seven or eight rats, it is generally about two feet square, and is made larger in proportion to the number it has to contain; it has also as many apartments as there are families. All these arrangements show marks of intelligence; but there are yet others.

It is well known how cleverly rats can swim. They cross rivers to procure food from houses and gardens, and generally make the passage at break of day, for fear of being detected. The following incident proves the cunning of this animal. A number of rats had taken up their abode near a dogkennel, in which was lodged a great many pointers. The food of the latter was put into narrow troughs, and the rats were accustomed to come and partake of the dinner with the dogs, which, trained for higher game, despised these little mean gnawers. The latter, seeing no danger, came in such numbers that they devoured the daily food of the dogs, and the master of the kennel resolved to destroy these marauders. With this intention he made a hole in the wall, at the end of each trough, and placed in the openings the muzzle of a loaded gun, so as to destroy the rats at one blow. At the usual feeding-hour he stationed a servant at each gun ready to fire. Having securely locked up the dogs, he gave the signal for putting the food into the troughs, and retired to the kennel, intending to wait until the rats 
were so much occupied in the trough that they might all be killed by a single discharge. He waited patiently for a long time, but not a single rat appeared. Having allowed the food to remain for about an hour without seeing any rats, he released the dogs, who immediately rushed at their dinner. They had scarcely commenced theirrepast when the rats showed themselves, and, as if they knew they were being guarded by the dogs, kept their accustomed place in the trough. They had never before dined with so good an appetite. The intelligence of the rat is such, that if it has once escaped from a trap, it is seldom caught again. Many other examples might be given to prove

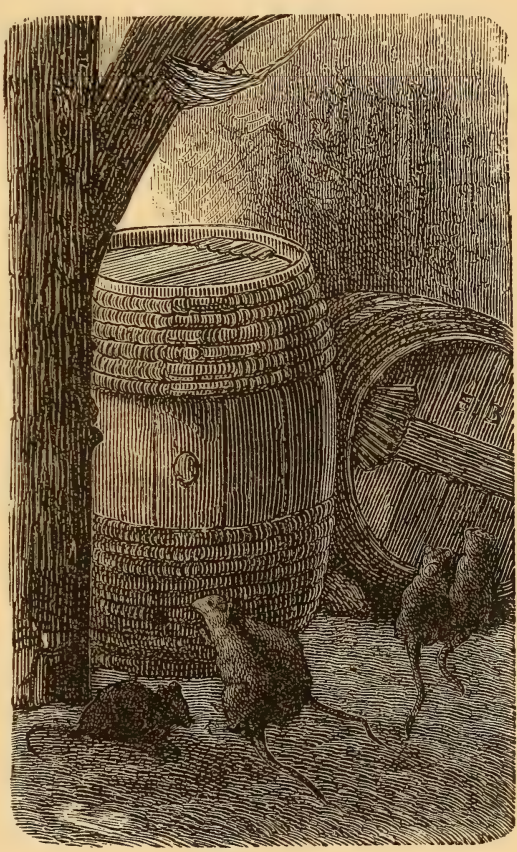

Rats attacking the Spirit Casks. the extent of their sagacity. Dr. Franklin tells us, that when rats gain admittance into a vessel all goes well with them so long as the cargo is on board and they can procure plenty of water, which is most necessary to them; but if it be too well guarded for them to obtain it easily, they have recourse to very extraordinary devices in order to procure some. During 
a very rainy night they come on deck to drink; then they climb the rigging to collect the water which they find in the folds of the sails. If they are reduced to great extremity, they attack the spirit casks, and drink so much that they are unable to regain their holes. Land rats gnaw even the metal pipes which, in public-houses, conduct the alcoholic liquors from the cask to the counter. All the race have very finely-organised ears, to catch the sound of flowing liquids. No doubt, the difficulty they find in procuring water has, in several cases, induced them to leave the vessel as soon as it touches the land.

Examples of the sagacity of rats are too numerous to mention. The ingenious devices by which they often secure coveted food have every mark of reasoning. They have often found eggs stored up by careful housewives in a dry loft at the top of a house, and have actually contrived to carry the eggs down whole flights of stairs to their holes in a deep cellar. This feat has been watched by angry householders anxious to counteract the stratagems of the wily plunderers. According to the statements of these observers, the rats appear to have skilfully combined to aid each other in lower. ing the eggs, one by one, down every separate stair. Their mouths and fore-paws were the principal means employed in the operation. Two rats have even been watched as they were conveying an egg up-stairs; in which bit of engineering one animal pushed or raised up the egg, and the other received it. On another occasion the rats formed a line, passing the egg along from one to the other. When a number of men form a line to hand buckets of water rapidly along, we call the act a rational proceeding : why should not a like combination be deemed a sign of intelligence in these animals? Rats have also been detected in the act of ex- 
tracting salad oil from the long and narrow necks of Florence flasks. One of the animals wrenched out the cork; then the same, or a companion, dipped his long tail into the flask; the others instantly licked the delicious oil off the soaked tail, and by repeated dippings of this kind the flask was soon almost emptied. Mr. Buckland mentions a case in which the rats combined to rob an old lady of her wine. The cask was placed in a cellar, and before many nights had passed the most extraordinary and even unearthly sounds were heard in the lower parts of the house. What could be the matter? Ghosts were suggested, as the simplest solution of the difficulty; but ghosts had never intruded before, and the lady had done nothing to attract such visitors. She was, however, determined to resist such an invasion on her domestic peace, and called in not spiritual but earthly forces, in the shape of her labourers, servants, and a fierce dog. The rustic troops being armed with hay-forks, the housemaid carrying a large hand-bell, and the bold mistress herself having two huge loaded pistols on a table before her, the whole party awaited the attack of the supernatural hosts. Strange as it may appear, no spirits came, though such beings are supposed to hold carnal weapons in the most supreme contempt. However, if the unwelcome visitants did really return, they conducted themselves in a quiet and respectable manner, the horrid sounds being heard no more. The day at length arrived when some of the wine was wanted for a festive gathering; the cask was visited, and a moment's glance showed a burglary of the most shameful kind. The bung had been gnawed through, and then, when the wine had sunk down to that level, the wood below was bored through. There was no mistaking the teeth marks; no human tool would have left such peculiar cuttings on the 
perforated staves. Not a quart of the wine remained, and it was evident that the rats had actually got into the cask and sipped the liquid to almost the last drop. The outcries had doubtless been caused by the swarms engaged in piercing the cask; afterwards their enjoyment of such a rare treat kept the felonious epicures quiet enough. Much wine was wasted by running out of the holes; but this was probably licked up from the cellar-floor by the eager topers. The cask itself was immediately raised to the highest honours, being secured by Mr. Buckland and placed in his museum as a memorial, not only of rat ingenuity in combining for a common end, but of the wine-bibbing tastes of the animals.

Rats will also combine to attack their foes, and have been known to drive off even dogs when these were wanting in thorough-bred courage. The rats in the well-known fable were not able to procure one of their number to volunteer in "belling the cat;" but Mr. Rodwell mentions a case in which a fine cat was almost torn to pieces and killed by a concerted attack of these animals. Puss had long been famous as a rat-killer, but one night a very army of the foe must have suddenly sprung upon Grimalkin, and overpowered the hero.

Few would suppose the rat capable of being tamed, but some cases of this kind have occurred. These educated rats have followed their keepers about with all the fidelity of a spaniel. To train these animals so as to act in a theatre is, perhaps, not more wonderful than to teach fleas to perform the military drill, but it supplies one more proof of intelli. gence in such creatures. The rats in question displayed their talents before a Belgian audience, and were dressed up in miniature human clothing, in which they acted the 
parts of fine ladies and gentlemen. The whole perform ance was appropriately concluded by the hanging of a cat in effigy, round which the rats wheeled in a grand triumphal march!

The patience of the rat-destroyer is often severely tested by the caution of the animals. To no purpose is the trap set, in vain the poison is laid, if a human ungloved hand has touched either. The rat detects, by his acute sense of smell, the odour of the fingers, and the trap should, therefore, be touched with a perfumed glove or cloth. The poisoned food is placed on spots to which the rats are gradually enticed by the presence of rags dipped in oil of rhodium or in preparations of musk, carraway, or aniseed. When they have become used to these places, and fed on bits of refuse meat, tallow, \&c., they will collect in great numbers, and, losing all fear, will then eat the poisoned food. Nothing but patience and tempting food, carefully left for a time, will succeed in lulling their marvellous suspicions.

The belief that these animals are sometimes employed as agents of Divine justice has given rise to a Polish legend, in which it is said that King Popiel poisoned his uncles, and threw their dead bodies into a lake. These corpses attracted an enormous number of rats, which afterwards attacked the king, his wife, and children. Nothing could stop their desperate fury; the servants vainly endeavoured to destroy them with fire and weapons. At last all the king's family sought refuge in a strong hold; but the rats pursued them even there, and, in the end, killed the king and all belonging to him, in the Castle of Kruszwic.

Mice must not be entirely passed over, although their ingenuity be not quite so astonishing as that of the rat. Mrs. Lee gives an account of the persevering skill with 
which a colony of mice attempted to get at some dainty food placed under a heavy metal dish cover. Unable to get to the top, from the smoothness of the surface, they actually formed a living ladder, some mounting on the shoulders of others. When this was accomplished nothing was gained, and the little creatures then tried to insert their small legs under the edge of the cover in order to raise it a little, but the weight was too great, and they only got several ugly pinches for their pains. The plan was, however, evidently dictated by intelligence. Mr. Jesse records an attempt successfully made by a mouse to reach the top of a honey pot. The closet containing the prize had some loose mortar and plaster lying in a corner, and of this the clever mouse used to construct a mound against the smooth side of the jar. This enabled the cunning workman to mount to the top of the vessel and attack the honey. But the getting out of the pot seems to have been nearly as difficult as getting in, and the mouse therefore made in the inside an inclined plane of the mortar, up which it could easily run when its appetite was satisfied. What but intelligence could have suggested this effective mode of accomplishing the object? The double-inclined plane showed design on its face.

A story had been told by an Icelandic naturalist of the amazing sagacity shown by mice in crossing rivers when searching for food. The statement was that eight or ten of these mice would collect a piece of thin turf or dry cowdung, then, dragging it to the edge of a stream, all get upon the novel raft, sitting with their heads turned to the centre and their tails in the water, and thus, using their tails both for oars and rudder, get across. The story sounded to some very much like an invention, others were disposed to belief, and Pennant, in his great work, "The Arctic 
Zoology," took the latter side. The unbelievers received great support, on the other hand, from Dr. Hooker's " Tour in Iceland," in which the migrating skill of the mice was denied. But surely, thought Dr. Henderson, a simple question of fact can be answered in some distinct manner. $\mathrm{He}$ made close inquiries among intelligent Icelanders respecting mice navigators, and gives the names of educated residents who had themselves seen the animals in the very act of making their singular voyages. If these facts be admitted, the inevitable conclusion must be that these Icelandic mice act, in some cases at least, on rational principles.

Our pretty little harvest mouse, the smallest of English quadrupeds, shows no small ingenuity in suspending its nest to corn stalks or thistle stems. Let any one inspect one of these compactly platted little nests. Mark the firstrate style in which the small opening is formed, and note the endurance of the structure, which may be rolled to and fro like a ball without losing the "cricket ball" shape. The examiner cannot fail to be struck with the skill shown in the construction of the mouse cradle, which often gives shelter to seven or eight young. Some of the nests lose their shape by handling, but these are generally formed of soft grass, cut into short pieces by the maker's teeth, and admirably woven together.

The extraordinary living bridges formed by the lemmings of Norway, in order to cross rivers, demands a moment's attention. The reader is, doubtless, aware that these rat-like animals sometimes emigrate from their homes in the Norwegian mountains in such countless myriads as to lay the whole country waste through which they pass. Sometimes the vast army come to a river. There is no time for pausing; 
the multitude behind force the van to advance. What is done must be done quickly, and this is the scheme adopted by these pontoon makers. A column of lemmings manage to swim across the river, the rear ranks resting their heads on the hinder parts of those in front. The foremost rank of the column grips the earth or plants on the opposite bank, and thus secures a fixed point of support for the bridge. No sooner is the lemming column firmly fixed at the front and rear, than the whole army rushes hastily across on the backs of their companions, which thus form an extemporised floating bridge. As these operations have been recorded by eye-witnesses, we must receive the statement as furnishing another argument in favour of the intelligence of the lower animals.

If the accounts given of the marmots are but partially true, then these "Alpine mice" must also be classed amongst the intelligent rodents. Animals which form snug winter homes in the earth, passing the cold season in societies of about a dozen each, which actually "make hay" for themselves, their mouths being scythes and their paws the turning machines, must take rank among "the wise creatures" of the earth.

The jerboas, or jumping mice of Egypt and Asia, are not only famous for their wonderful leaps of fifteen feet at a jump ; they are remarkable also for the mode in which they lay up stores against a time of want, forming complete magazines of food. The particular point to be borne in mind is, that the jerboas do not use the stores thus laid up as mere instinct or appetite might direct: prudence and forethought seem to be exercised. The food deposited in the granaries is never touched while any supplies can be procured from the fields. When these sources fail, then the closed magazines 
are opened. Sometimes the natives discover the stores and carry off all the grain, leaving the jerboas to contend with hunger or to perish.

We thus see that in rats, mice, lemmings, marmots, and jerboas, gleams of intelligence appear, proving that something more than instinct is granted to these creatures. They clearly are able to adapt means to ends, and devise schemes suited to emergencies. 


\section{HARES AND RABBITS.}

NATURE has bestowed upon the hare less sense than many other animals, but, when pursued, it has recourse to a degree of cunning capable of exciting the envy of the fox. Huntsmen tell many well-attested stories which show that even hares can vary their actions when circumstances require. Some have been known to stop in a brownishtinted soil, and lie down between two clods which happened to be nearly of the same colour as themselves. One has been seen to swim into a bed of reeds in the midst of a large body of water, and, having thrown out the dogs, to have waited quietly till the pack went by. Hunted hares will sometimes dash amongst a flock of sheep, and lie down, with the evident object of thus concealing themselves. The doubles of the hare are often of the most extraordinary kind. The animals will jump on to a wall, run along the top, and even try to creep into dense masses of ivy growing there. They will run in and out of a thicket several times, as if they knew that such a manœuvre must puzzle the harriers. Wide rivers will not deter these usually timid creatures when danger presses. Mr. Yarrell mentions one case of a hare swimming above a mile across a tidal harbour. But the time when the animal took the water indicated something like powers of reflection. The hare waited on the shore while the tide was running in, and, just as high-water was reached, took its swim. The quadruped navigator was 
evidently aware that if the journey were attempted during the sct of the current, the motion of the flow or the ebb tide would carry it past the exact point of land on which it wished to land. The poet Cowper's tame hares will occur

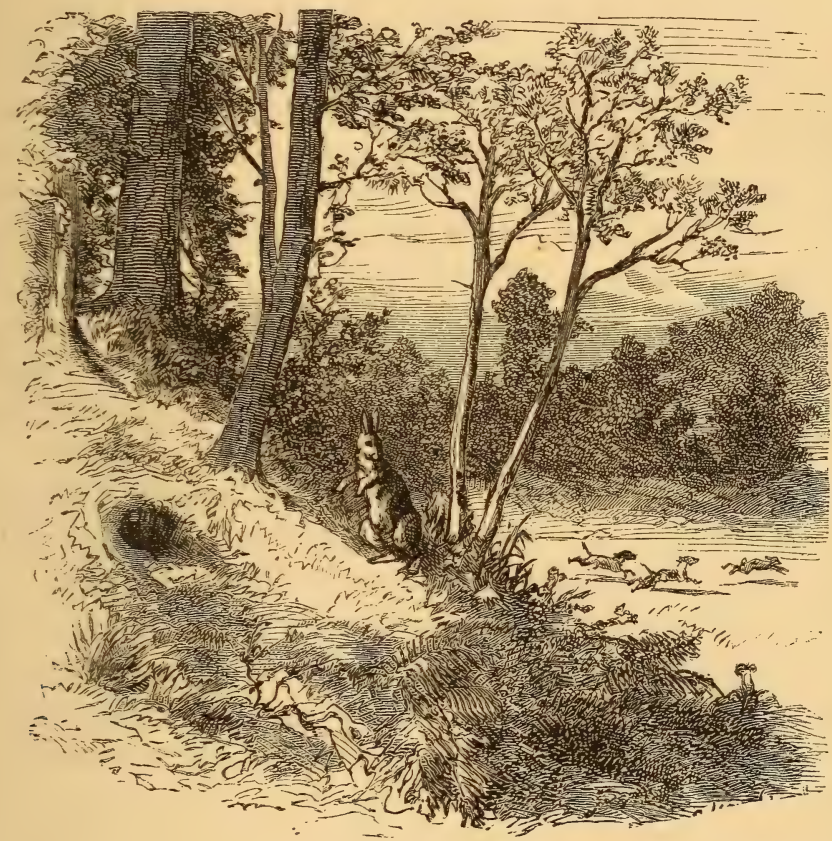

The Hare running in a Straight Line. The Rabbit Doubling Back.

to many readers as instances of the capacity of these usually wild animals for some degree of domestication. But surely this teachableness implies the possession of intelligence.

The rabbit, though much weaker than the hare, possesses much more intelligence. A dog is very likely to take a hare 
in coursing, but a good rabbit sometimes can tire out the best of dogs. The rabbit digs out his hole, chooses a mate, and lives in society. He does not confine his interest to his own family, but extends it to all the underground republic, and to those creatures of his kind which share with him the produce of the neighbourhood. When the rabbits leave their burrow to feed, those which by experience are accustomed to note alarms always divide their attention between their meal and any peril likely to surprise them. If they think any danger threatens, they give the alarm by striking the earth with their hind-feet, and all the neighbouring burrows immediately resound with these repeated strokes. The whole tribe generally hastens to re-enter, but if there are any younger and more imprudent rabbits, which do not heed the first warnings, the old ones still continue striking, and risking their own lives for the public safety.

George Leroy remarks that the propensity of rabbits for burrowing is not purely mechanical, since those that have been a long time domesticated do not attempt such works. They only think of doing so when the necessity of protecting their weakness from cold and danger has forced them to provide this shelter. "It is not, then, always from a superior instinct," adds this clever observer, "that some species do things which indicate more sagacity than is shown by others. It seems certain that if cold or other inconveniences had not made the rabbit suffer more than the hare, this animal would not take the trouble to burrow a hole. People attribute that to its industry which is really owing to its weakness."

To work in concert for the purpose of making a dwelling and lodging together is a new order of things for beings formerly wandering without a dwelling. "It is 
impossible," says George Leroy, "that property should not stimulate labour, and establish connections of neighbourhood. The idea of property is evident in rabbits. The same families occupy the same holes without changing them, and the dwelling increases according as the family augments. They take a lively and courageous interest in all animals of their species." 


\section{THE BEAVER.}

THE beaver is the animal whose instinct and intelligence have been the most discussed. "It is," says M. Flourens, "a mammiferous animal of the order rodentia, the order which has the least intelligence. But it has a marvellous instinct for constructing a hut, for building it in the water, for making causeways, and forming dykes, and all this with an industry which seems to be the effect of a very high intelligence in this animal. But are its works guided by intelligence? The essential point," adds M. Flourens, "is to prove that they are not so guided, and this is what F. Cuvier has done. He took some very young beavers, brought them up far from their parents, which, consequently, could not teach anything to them. These isolated, solitary beavers had been placed in a cage, so that they should not want to build; yet these beavers built, urged on by a blind, mechanical force, in one word, by a pure instinct. This admirable industry which the beaver displays in building its hut, is employed by it for that purpose only." In another place M. Flourens speaks again of the instinct which springs from a natural impulse, and he adds, that the beaver which F. Cuvier studied was taken on the banks of the Rhone, was artificially suckled, and could not, therefore, have learned anything from its parents. It was constantly fed with branches of a willow, of which it ate the bark; and 
after having taken all the bark off the branches, it cut them into pieces, and piled them up in a corner of the cage: it was collecting materials for building. They now furnished it with earth, straw, and branches of trees, and saw it form little masses of earth with its fore feet, then push them in front with the chin, move them away with its mouth, place them one on the other, and press them hard with its tail, till the result was one solid mass. "But," says M. Flourens, "two facts must be noted here: one, that this animal did not owe anything to its own race, the first source, according to Buffon, of the industry of the beavers; the other is, that this animal works without an end, mechanically, forced by a blind impulse. No good could result from the trouble which it gave itself." It needed no house. Buffon will have it that solitary beavers do not know how to undertake or construct anything. Cuvier's beaver undertook, constructed, and built, but it was solitary.

"If we believe Buffon," adds the learned academician, "the beavers are perhaps the only examples which exist of this species of intelligence in brutes, which, although infinitely inferior to that of man, nevertheless supposes common projects and views." "The society of beavers," he says, "not being a forced union, must be a species of choice, and supposes at least a general agreement and cornmon objects, and also a gleam of intelligence in the beaver." To this M. Flourens answers, that Buffon takes the result of instinct for the result of intelligence. Buffon and M. Flourens are both right, for an animal may be forced, by its nature, to do something spontaneously, and this act, which originally was only instinctive, may afterwards be executed with intelligence. . Is not this what we 
frequently see among men? A child feels itself drawn to some art; first, it exercises it instinctively and mechanically; later, it works with intelligence. A beaver lived, some years

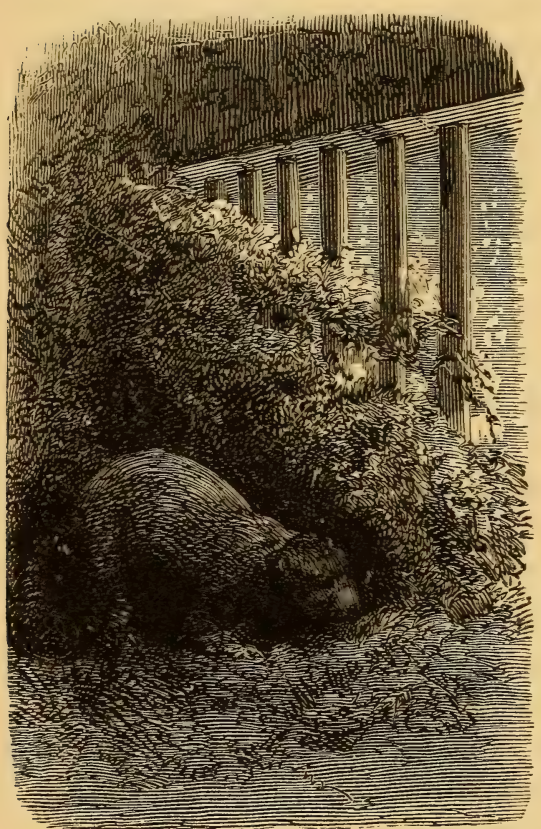

Beaver building a Wall. ago, in the Museum of Natural History at Paris. They threw to him, in his cage, vegetables, fruits, and also branches to amuse him. During the course of a hard winter, the animal had only a little litter to protect it from the cold, and the door of its cage shut badly. One night it was snowing large flakes, and the snow, driven by the wind, accumulated in a corner of the cage. It was necessary to invent a plan for protecting itself from this new inconvenience. The only materials which the poor beaver found were branches of trees, which had been given to exercise its faculty of gnawing. It now interlaced the branches in the bars of its cage, just as a basket-maker would have done. Before day came the beaver used up the litter, some carrots and apples, and all it had at hand, fashioning the materials with its teeth, and appropriating them to the vacant spaces, 
with the idea of filling them up. This protection from the cold air not seeming sufficient, it covered all with snow, which froze in the night, and by the next morning it was found to have built a wall, occupying the two tiers of the door. This barricade made against the cold shows an instinct for construction, and also denotes reflection and intelligence. What other name, as Dr. Franklin has very well said, can we give to a series of acts having for their object the application of instinct to circumstances which the animal had not foreseen?

We could mention many other facts to prove that instinct may be the first impulse to an act, which later becomes an intelligent work. M. Flourens, perhaps, only insisted that the beaver had no intelligence because this animal has not any cerebral circumvolutions!

Another fact will prove the intelligence of beavers. We received it from M. Broca. Wherever beavers find favourable conditions, they live in society, they build villages, where each family has its hut; an admirable construction, in which the art of the carpenter is allied to that of the mason. The choice of place, the preparation of materials, the disposition of the causeway, the building of the huts, are all witnesses to a really remarkable intelligence. We are told, however, that the beaver is not the inventor of all these things; that nature having created it sociable, an engineer, and a mason, it blindly obeys the will of nature ; that it has always thus lived, and cannot live otherwise. This opinion might have been supported three or four centuries ago. It cannot be supported to-day, as the beavers of some regions have adopted a mode of life totally different.

Societies of beavers were found in France till the end of 
the Middle Ages, in spite of the attacks of men. In I80 I there was a colony on the Elbe, near Kähnert; another in I830, on the Nuthe, an affluent of the Elbe. As soon as man brought to perfection his arms and weapons of the chase, the beavers redoubled their prudence, cunning, and sagacity, but they were forced at last to yield before firearms. Social life was attended with too great dangers; the sweets of association therefore had to be renounced. Families dispersed, and not finding security in their huts, which attracted the attention of man, the beavers sought refuge in the crevices of cliffs which lined the banks of streams.

Beavers inhabited the Vosges till near the end of the I 7 th century, and still exist in the mountainous districts of Dauphiné, and on the banks of the Rhone. They excavate habitations in the dykes of the river, and there take refuge, where man cannot pursue them without destroying his own works.

Thus the beaver did not only renounce social life, but also adopted manners and habitations quite new, and created an industry which was unknown to it, when at liberty to display its true nature. The mason became a miner; it first constructed, next excavated, contrary to man's custom, who first hid himself in caves, and later, having nothing to fear from savage beasts, constructed dwellings in the broad daylight.

It must, therefore, be confessed that if the primitive beavers, in adopting social life and building villages, were only obeying blind instinct, the beavers on the banks of the Rhone could not have adopted the means of now living contrary to what is called nature, except by their intelligence adapting itself to new requirements. 


\section{THE RUMINANTS.}

RUMinants are animals like the ox and the cow, which have the habit of "chewing the cud."

According to their cerebral organisation these mammalia are superior to the rodents. They are the first animals in which the brain hemispheres have circumvolutions, two lobes covering the two pyramids and the two "olivary" bodies.* We know that the rodent does not often distinguish the man who takes care of it from any other man; the ruminant knows its master, though a change of the coat often suffices, says M. Flourens, to prevent recognition.

The heads of ruminants are in general long; all have large and well-formed eyes, but are not very intelligent looking. These animals are well organised for eating. Their stomach has too much digestive power for their brain to reflect much. They are thought to be of a more affec. tionate character, more docile than the carnivora; but observation shows that most adult ruminants, especially the males, are rough and wild, little influenced by kindness, scarcely recognising him who feeds them, not attaching themselves to him, and always ready to strike the moment he ceases to intimidate them.

Ruminants, when they gain strength, are really more unruly than the carnivora-that is, their intelligence is much lower and much more limited.

* Parts of the inner brain, so named. 
We do not communicate our intelligence to animals, we only make them develope their own, and apply it to a greater number of objects. Many among them have been domesticated, and have rendered us great services; but in becoming slaves, have they not become more intelligent? Certain authors say that the ruminants have lost something of their natural faculties. The affection for the race is very weak, and does not last long; the females only show some solicitude for their little ones. Wild beasts, of which they are the principal food, and hunters, who pursue them without ceasing, would have made them disappear from the greater part of the earth if they had not been protected by acuteness of hearing and rapidity of flight.

It is remarked that nearly all animals living on grass pass much of their life in a state which approaches habitual torpor. The life of carnivorous animals is much more busy and active, but these and the ruminants find happiness in the exercise of their natural faculties, and there are very few species of the latter which feel any wants independent of their simple appetites. This disposition for repose is perhaps what hinders, says G. Leroy, the species from perfecting themselves as much as their organisation would permit. Yet there are certain ruminants which display a real intelligence. We will first of all name the follcwing. 


\section{THE CAMEL-THE LLAMA.}

THE camel is said to be the first of all ruminants in intelligence. This animal is very docile; it is taught while young to bend down and to kneel when about to be loaded. As

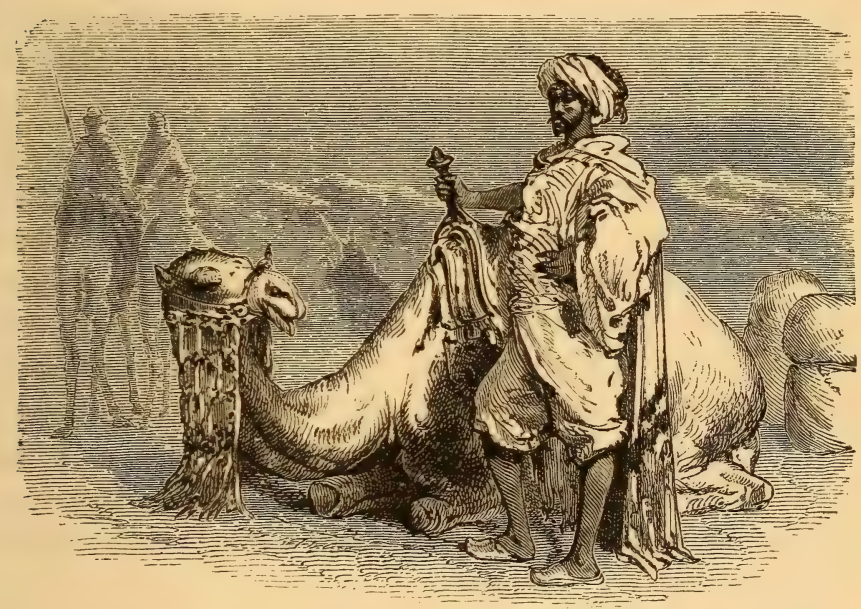

The Camel about to be Loaded.

soon almost as it is born the keepers bend its four legs under the stomach, and cover the animal with a carpet, on the borders of which they place stones, so that it cannot get up. The "breaking in" generally takes place when the camel is four years old. One of the fore legs is raised and tied up; 
the animal then gently falls upon its knee, and in a short time learns to do so at a word. The trainers leave it thus for some time without letting it suck, so that it early acquires the custom of rarely drinking. The owners do not allow their camels to carry burdens before the age of three or four years. And, when the beasts feel they are sufficiently loaded, you must not, says Valmont de Bomare, think of loading them any more, or they are discouraged, shaking the head, and starting up. If they are overladen, they set up a lamentable cry. The camel has one great fault; it is spiteful, and becomes dangerous to those who drive it too roughly; it long remembers any ill-treatment, and when it can catch its enemy, takes him up with its teeth, lets him fall down on the earth, and stamps on him till he is crushed. The expression "camel's temper" denotes, in the East, an unforgiving man. This bad humour is but a temporary excitement, and the camel, after all, is an excellent animal, which has not, as has been said, any antipathy to the donkey, the horse, and the mule. Whenever it finds itself in their company the camel is, on the contrary, very good society. This beast has a singular power for detecting the position of pools of water. A camel has rushed headlong to the hidden waters when neither men nor asses were aware of the presence of the element.

The llama, which comes very near the camel in its organisation, is, like it, docile and intelligent. The gait of these animals, and their long, narrow, pointed, and movable ears, show great vivacity. Their paces, without being light, are free and sure; they are timid without being afraid; they readily place confidence in those that take care of them, and even seem susceptible of a deep affection. As the padded foot of the camels would have been 
a hindrance to the llamas in climing rocky steeps, its place is supplied in the latter animals by strong hooked claws, with a separate cushion behind each. This gives great freedom to the foot in combination with a firm grasp of the ground. 


\section{$\mathrm{O} X \mathrm{EN}$.}

IT is said of a slow, heavy, and narrow mind that it is dull as an ox. Certainly this mammal has not as much intelligence as the ant or the spider; which proves that a large head, and a brain provided with circumvolutions, will not give a mind. We have already said, and we must repeat, that the stomach often stupefies intelligence. Great eaters generally finish by heaviness of mind. He who is all for eating is little for thought. It must not be supposed, however, that the ox is a fool, with whom you may do as you please. In order to tame and subjugate it, you must take the animal at the age of two and a half or three years; if you wait longer, it often becomes untameable. Patience, gentleness, and caresses have a good effect on him, while bad treatment disheartens him and paralyses the little intelligence he possesses. When well brought up, he is gentle, patient, and hard-working; and, without having great intelligence, draws his plough calmly and courageously. The bull, on the contrary, will fight most bravely for the herd, and walk proudly at the head, announcing himself by a grave lowing, as you may hear in the first days of spring, when these animals come to take possession of the pasturage. If there are two herds in a field, the two bulls will detach themselves from them, and advance towards each other, animated by a feeling of jealousy; the lowing is the signal for action. Then the two rivals fall on each other with impetuosity, and butt with fury. The first shock is 
followed by a second, then by a third; they fight with frenzy, and do not cease the combat till they are separated, or till the weakest is constrained to yield.

In the ruminants, it is cbserved that the difference of character between the male and female is more marked than in any other class of animals. It would be difficult to find

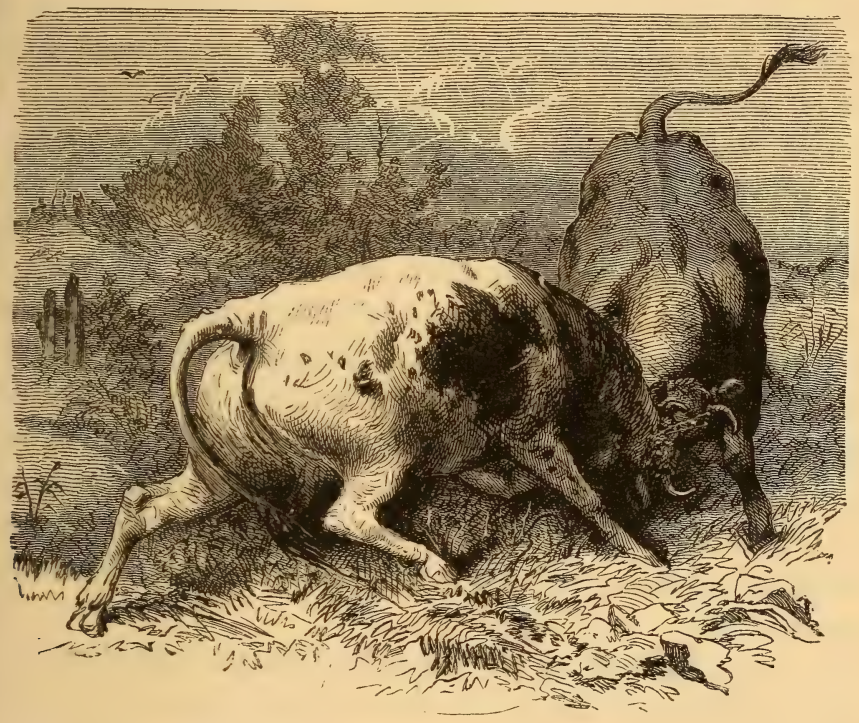

The Two Rivals.

characters more different than the bull and the cow, the hegoat and the she-goat, the ram and the sheep, the hart and the hind.

The fierce energy and intelligence of the bovine race can be but feebly marked in the domesticated species. A prize "Devon," or show "Hereford," is too much cared for 
by man to allow of any quality to be developed except the capacity for getting sleek and fat. The hunter who has me the charge of the wild bison of the American prairies, 0 fought with the fierce African buffalo, can alone estimate fully the natural resources of the animals. The small bu fiery eye, the long shaggy hair, and the vindictive charge 0 a wounded bison, make the boldest man feel that such : creature cannot be called "stupid." No little skill is neces sary to surprise these watchful animals, which scan every far-off movement, and sniff the wind with suspicion. The bravest bull-dogs soon learn, when they close with a bison, the effective fury of its peculiar mode of attack. This is made by striking at the dog with their fore-feet, one blow o: which will stamp the assailant into the dust. A pack o: famished wolves will hesitate before charging the disciplined array of a bison army. All the young and weak animals stand in the centre, the rest form an impenetrable circle of horns, against which even the savage prairie wolves will seldom dash. Those who have seen the wild oxen preserved in Chillingham Park, Northumberland, will notice in their mode of advance to the attack a concerted combination of movement.

"As stupid as an ox" may be current now, but there was a time when the animal was treated as a god, or made the symbol of Divine attributes. The Egyptians found a home for their great divinity Osiris in the body of an ox, and Nineveh even joined the human head to the bovine body. The winged and human-headed bulls in the British Museum show the reverence paid in remote ages to this animal. The strange mythology of India has made the bull the sacred animal of Siva, and millions of. Hindoos at this day revere the creature as the representative of Deity. 
A few words on the Cow are necessary, not because she is very intelligent, but because she has such a good heart! The cow shows that she hears her name, and understands very well the words which express an order or a prohibition. She accustoms herself to the persons who take care of her; and if a strange hand tries to milk her, she withholds her milk.

Cows appear very tender in the bringing-up of their calves; they complain in their own way, and low when they hear the voice of the young. "They have been seen," says Fée, "hurrying towards the habitation and trying to get in, deceived by the cries of children they have heard." If the persons charged with distributing the fodder pass by without giving them some, they make a plaintive lowing. They have a sound for joy as well as grief.

Let us notice, lastly, a spirit of subordination very remarkable in cows. When the herds repair to the Alps, to pass the summer season there, you may see the leading cow walking proudly at the head of her companions. This cow preserves her authority in the pasture-grounds, and returns in triumph to the valley, always at the head of her companions.

This animal has, on several occasions, given proof of a higher intelligence than most persons would expect to find in her. Memory is, undoubtedly, an intellectual power, and this some cows have certainly possessed. Mr. Jesse states that a cow was taken away from her calf, which was left at Bushey Park, the mother being hurried off to Smithfield. The next morning the cow duly presented herself at the gate of the yard in which the calf had been kept. Of course there was great surprise and some anger as the question was asked, "Who brought the cow back ?" The inquiry might 
have been repeated until now, and no answer have been obtained. That cow wanted no guide. She had by some means broken out of her London home, and had passed through all the streets to the suburbs without being stopped by the police, who naturally fancied the drover must be close at hand. Once out of the streets, the route was plain enough to such a sagacious animal, and the twelve miles were soon traversed. Affection for the calf may have been the impulse which drove the cow back, but she must also have had a strong recoliection of all the streets and turnings through which she had passed from Bushey to Smithfield. The following instance shows a still more retentive memory. A cow had been sent away from her own pastures to a place about twenty miles off, in the spring. As the feed was good, she remained quietly in her new home through the summer; but as winter drew on the quality of the grass changed for the worse. The cow resented this, and, escaping from the pasture, presented herself at the old home, with sundry eager and indignant lowings. In this case the animal's memory must have retained the chief landmarks of the journey for about half a year. A species of the zebu, or hump-backed cow of Africa, is said to be trained by the Hottentot shepherds to guard large flocks of sheep. She keeps them together with all the activity of a Scotch colley, and repels every enemy with unflinching courage. These facts show that the cow is capable of receiving a higher education than she usually obtains. 


\section{THE STAG.}

ITS REFLECTIONS AND ITS DEVICES.

THE study of this timid animal furnishes us with a new proof of the transformation of instinct into intelligence. When young, it is frightened at the barking of dogs, and flies instinctively; when old, its flight is the result of reflection. However, the stag is one of those animals whose constitution, inclinations, and manner of nourishment do not lead to much intelligence. It has no difficulty to conquer in getting food. If it suffer from scarcity, it has no other resource than to change its place, and cannot help itself by any kind of industry. Thus its memory is only charged with a small number of facts. The stag soon learns and knows where it will find catkins and tender shoots in the beginning of spring, fresh and juicy grass during the summer, berries at the end of that season, and briars or heather-tops when the winter has dried the herbage and covered the grass with snow. The repetition of such simple actions does not give much instruction. To go out of the retreat in the evening to feed, to re-enter at the dawn of day and go to rest; to rise sometimes towards mid-day to eat, or, if it be very hot, to drink at some pool, this is the history of a stag's day, and such it would be all his life if the excitements of epring and the snares of men did not make some variety. However, these actions, simple as they are, 
show in the stag experience, reflection, and choice, for it is necessary that he change his pasture-ground and places of retreat according to the seasons. In the spring and in the beginning of summer, the necessity of renewing his horns and procuring fresh and tender herbage, obliges him to seek lonely thickets, where he may hope for tranquillity. In winter, the rigour of the cold teaches him to inhabit woods and the depths of forests bordering on pasture-grounds. But this choice of retreat only supposes one reflection drawn from a single observation. When he has been several times disturbed in his asylum, he puts into action an art which can only be the fruit of finer and more complicated reflections. He often changes his coppice with the direction of the wind, that it may bring the smell and sound of anything which may threaten him from outside. Often, instead of entering in confidence and going straight to rest, he makes pretences of entering his lair; he goes into the wood, comes out, passes and re-passes on his tracks several times. Without having anything really to disturb him, he employs the same devices as he would if hiding himself from the dogs were he hunted by them. This caution supposes facts already known, and a series of ideas and presumptions which are the consequences of these facts, for such proceedings must necessarily be the product of reasonings like these which follow : - "A dog, led by a man, has several times forced me to flee, and has followed me a long time by my tracks. My tracks, then, are known to him. What has happened many times may happen again to-day; so to-day I must take precautions against what has already happened. Without knowing what is done to mark my track and follow it, I presume that, by means of a false march, I could mislead 
my pursuers; so I must go and return on my tracks, to deprive them of their knowledge and ensure my quiet." "Whoever," says George Leroy, "will reflect on the necessity of a motive to produce such a complicated determination, will see that this cannot be the result of what is called instinct; it is, in fact, reasoning and intellgence."

To be afraid of the noise of dogs, and to escape from their pursuit, is, in a timid animal, the pure effect of instinct; but to direct its flight according to known facts, and to reason on them, is the effect of an intelligent principle, which cannot be despised in the stag. When the creature is without experience, its flight is simple and without method. As he only knows the places near to that where he was born, he returis there often, and only quits them with regret and at the last extremity. But when the repeated necessity of hiding from pursuit has obliged the stag to reflect on the manner in which it has been pursued, then the animal forms a system of defence, and uses all varieties of designs and tricks to baffle the foe. Perceiving that in the thickets the contact of his body leaves a strong scent on the trees, which the dogs can follow with ardour and without interruption, the stag leaves these thickets, and goes into the woods or by the side of the road. Thus he prolongs his flight, changes his country, and gets far away. But, though he no longer hears the dogs, he knows they will soon approach; so, instead of yielding to a dangerous security, he profits by this time of respite to think of methods for deceiving his enemies. He has remarked that he was betrayed by the traces of his steps, and that the pursuit constantly followed them. To hide his road, he often runs in a straight line, returns on the same track, and 
at last, springing from the ground by several consecutive leaps, he puts to fault the sagacity of the dogs, deceives the hunter's eye, and at least gains time. Sometimes he begins running as soon as he hears the dogs. Sometimes he begins by stratagems, as if he were unable to run, and then all at once starts away with all the speed of which he is capable. But if he is pressed, it often happens that he throws himself on the ground, in the hope that the ardour of the dogs will carry them on, and that they will go beyond the track ; and when that happens, he turns quickly back again.

Often he seeks other animals of his kind to lose himself among them. Is it a natural instinct which leads to his seeking company to keep him safe? He has another motive; his partnership does not last as long as the danger. When the herd which he has joined is excited enough to partake of the peril with him, and the ardour of the dogs is at fault, he leaves the exposed herd and gets away by a rapid flight. This trick is one of which the success is surest. We find, in Budé's " Treatise on Hunting," all the schemes contrived by the stag to save itself; how he avoids going against the wind, how "one sees the stag get into a herd of oxen, and 'eap on one of them, holding on by the legs and foreshoulders, running a long time as if he were on horseback, touching the earth with only his hind feet, and thus leaving the dogs little scent of him." 


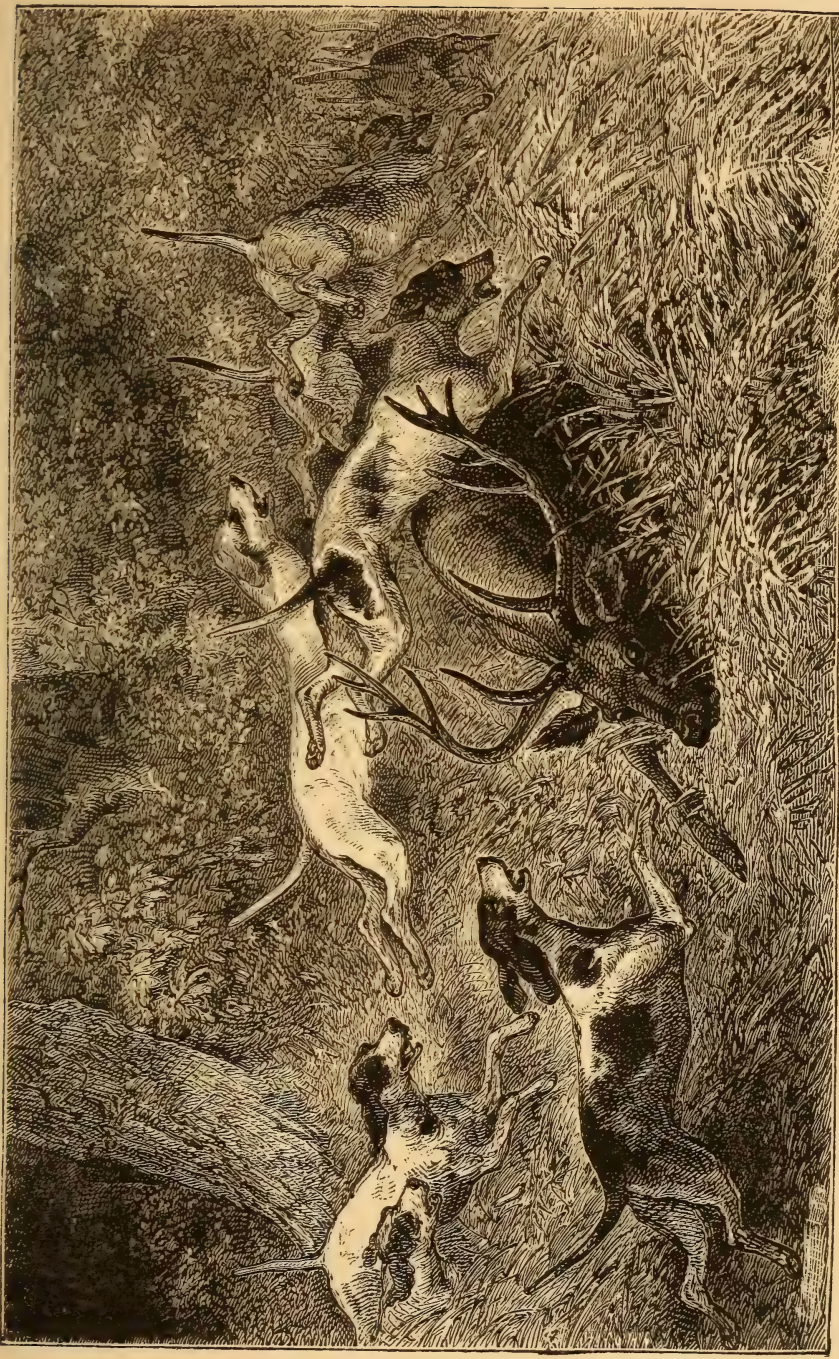

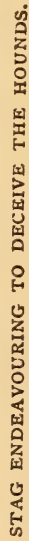





\section{SHEEP, GOATS, AND ANTELOPES.}

THE phrase, "a sheepish person," is never deemed complimentary, nor is it used to denote a strong or active understanding. Surely, then, the animals which have furnished us with the epithet "sheepish" must be remarkable for stupidity. This conclusion is not unreasonable in persons who know little about the habits of sheep. He who looks at a flock pent in by hurdles in a turnip field, taking their food just as it is provided, and being under no necessity to look after their own interests or safety, may not unnaturally think them stupid. But, even under these circumstances, the watchful shepherd, if he be himself an intelligent man, will be very likely to dissent from the popular opinions about these animals. Those who have noted their habits in open and hilly countries, where sheep are left more to their own resources, see nothing dull or heavy about them. The remarkable timidity of sheep in presence of the dog has probably greatly aided the common notion, though this suspicious apprehensiveness of danger has no connection at all with stupidity. The habit arises from the peculiar organisation of these animals, being necessary for their safety, and proving rather incessant watchfulness than the want of intelligence. Sheep are really courageous when necessary; the ewe will boldly face a dog in defence of her lamb, and the ram will charge the hound with all a warrior's fury. 
Sheep have sometimes given proof of a strong memory by the mode in which they have found their way back to the native pastures. Mr. Hancock describes the obstacles which an Annandale sheep overcame in her determined journey from Yorkshire to her former Scottish home. Another had been taken from Edinburgh to a place in Perthshire, having her lamb with her. She did not like her new home, and one day got off with her young one, making for the south, and actually reaching the former fold, with the lamb unhurt, after a journey of nine days. A singular fact happened when the watchful ewe arrived at Stirling. It was a marketday, and she patiently waited outside the town until the bustle was over, and then got safely through in the evening. Here was no mere instinct at work, but a faculty regulating the movements of the animal so as to meet a sudden emergency. Cases of a similar kind might be collected in great numbers, were they sought for in the proper districts by persevering inquirers. Probably a great number never pass beyond the particular localities where, after amusing the peasantry as a "nine days' wonder," they are gradually forgotten, or buried in the files of a local newspaper. Welsh sheep are said to have often escaped from even the neighbourhood of London, whence they have contrived to get back into Wales.

Mrs. Lee mentions a case which shows not only strong affection in the sheep, but an intelligent appreciation of human power to rescue animals from difficulties. A traveller in the Highlands was hurrying on through a lonely district, when a sheep ran towards him, bleating in a singular manner. This unusual action made the traveller pause, upon which the ewe ran back a little way, then looked towards the man and renewed the bleating. The human friend, to whom she 
seemed thus appealing, felt there was some meaning in the animal's actions, and followed her closely. The mystery was soon explained. Her lamb had fallen on its back between two huge fragments of rock, and was hopelessly struggling to escape. The little creature was soon liberated, and the man felt that this sheep was certainly a rational animal. Another remarkable instance, of a somewhat similar kind, is mentioned, in which the ewe, after trying to rescue the lamb, and finding all her efforts vain, ran off, with most violent bleatings, to a neighbouring field, to reach which she desperately broke through three or four hedges. After some time she returned, accompanied by a ram, which quickly pushed the lamb, by his horns, out of the thorny entanglement in which the little creature had been entrapped. In the former case the sheep, seeing no other aid near, had appealed to man; in this, the animal must have made her wants known to one of her own species. It is useless to involve ourselves in a metaphysical maze by asking how animals can thus convey information from one to another. It is something to note the results; that is within the province of natural history. The mode in which these results are accomplished is yet one of many psychological mysteries.

It is not to be expected that our domesticated sheep, which have everything done for them by man, should develop their natural faculties to any great extent. Could we note the habits of the argali, or wild sheep of Central Asia, or of the mouflon, the untamed race still existing in parts of Southern Europe, we might see abundant proofs of the sheep's intelligence. Whether the argali and mouflon are the originals of the domesticated breeds, or only descended from those which have escaped from man's 
dominion, is not the point for discussion here. A glance at the moufion might puzzle even one of the judges of the Smithfield Club to decide whether the creature most resembles a sheep or a goat; but there can be no mistake about the energy, daring, and courage of the animal. It is a splendid Alpine climber, and rivals the chamois in the boldness and decision of its leaps. Could these sheep be as closely watched as those on the Cheviots or on the Welsh hills, we should probably find reason for believing that the ovine race would rank rather high among the intelligent ruminants.

The readiness with which a single Syrian sheep will run out from the flock, when called by its name, has often astonished travellers. The animal not only acknowledges its name, but, if the shepherd be really a good one, will run up to be caressed, just as a dog would. There is no rcason for supposing that the natural faculties of these broad-tailed sheep are superior to those of our South Downs. Education makes the difference; but a capacity for training must be possessed by such animals.

The intelligence of the goat stands higher in popular estimation than that of the sheep. The physical energy and combative habits of the former have tended to produce this view, though not supported by any decisive facts. The sheep have certainly furnished us with more striking proofs of memory, watchfulness, and powers of combining for defence than the goats; perhaps if the habits of the wild ibex, and of the ægagrus, or mountain goat of Persia, could be more fully noted, we should find abundant proofs of their intelligence. The animals are, undoubtedly, well able to hold their own in the Alpine regions of the East, keeping in small companies sufficiently strong to intimidate their foes. 
The domesticated goat is well known for its inquisitive habits, prying into every corner, and inspecting new objects with a fearlessness which secures it from molestation. Some of these animals have shown a readiness to avail themselves of circumstances which would be thought clever in the dog or monkey. A goat had been often fed by the servants at a door. If the time for bringing out the expected food was allowed to pass by, the animal butted at the door until it was opened. The ingenuity of the creature went far beyond this ; she actually learned to imitate the actions of the postman and others by ringing the large bell, the wire from which hung close to the iron rails. The servants at first imagined that some mischievous person had rung the bell, and watched the area carefully. They thus detected the goat in the very act of inserting one of her horns into the ring at the end of the bell-wire, and then by a sharp movement of the head producing a sound which no servant could disregard. The animal must have observed persons ring the bell, and have noted how this was followed by the opening of the door. She must then have inferred that the same result would follow the like action by herself. If any readers object to this conclusion, they must at least admit that here was no merely instinctive process. Learning to ring a bell cannot be the result of an unreflecting impulse; it is not an act which all goats have performed from the beginning. One such case as this may show to what an extent the faculties of animals may be educated by the force of circumstances; but all such training goes far beyond the immutable workings of instincts. There must, therefore, be another power in animals-a power capable of development, and of adapting itself to circumstances. It matters little whether we call this faculty animal reason or an inferior 
degree of human reason, but we shall confuse ourselves and perplex others by naming it instinct.

The antelopes resemble the goats more than the sheep; indeed, it is sometimes difficult to distinguish the wild goats from some antelopes. The round and ringed horns of the latter may, indeed, generally serve to mark the varieties, but in form and habits many species of this large family of ruminants approach the wild goats. They are also like these animals in watchfulness and courage, but often excel them in beauty of form and elegance of motion. Unfortunately for the purposes of science, these animals mostly inhabit regions where civilised man has few opportunities of observing their habits. The Bushmen of Africa, or the wandering tribes of the Asiatic steppes, are much more intent on killing than on studying antelopes. The Eastern poets have, it is true, drawn many a rich image from the bright eyes and graceful movements of the gazelle, and beautiful women have borne the Greek name of the animal, Dorcas. But even if the habits of this one beautiful species had been fully and accurately noted, we should still be far from knowing the peculiarities of the remaining seventy or eighty species. The chamois is, indeed, found in Europe, and therefore falls more under the notice of educated men than other antelopes. But the lofty Alpine peaks or mountain glens in which the chamois loves to dwell, give few opportunities for observation by naturalists. The hunters, when intelligent, are most able to form a correct judgment about the animal. Their reports may help us to understand something of antelope life in general, and the narratives of travellers will give some notion of the countless swarms which traverse the plains of Africa and scour the uplands of Asia. The curiosity and 
inquisitive habits of the goats are equally exhibited by the antelopes. Any fresh object arrests the attention of the whole troop, which circles round the strange animal or man, getting nearer at each turn. This insatiable curiosity aids the hunter, who has only to wait till the prying animals come within rifle-shot. Thus the love of knowledge is not without its perils, even for antelopes; but the habit shows a fitness for the reception of new impressions. Most antelopes combine great caution with curiosity, and there appears to be no reason for doubting that many species perform their migrations under the guidance of a leader, and post watchers round about the host when they rest. It may be said that it is instinct alone which leads the oldest and boldest of the herd to place himself in the front, and that a like impulse disposes others to watch. Of course, all this is just possible; but the results are so like the suggestions of reason, that many persons will attribute them to some exercise of this faculty. So watchful are the sentinels of the Saiga antelope, that all the skill of the Russian and Tartar hunters, in their attempts to creep within shooting distance, is often baffled. In this sharp contest between the skill of man and the vigilance of the animal, even a little success on the part of the latter indicates the possession of faculties fitted to cope, in some degree, with human reason. The Whang Yang, or Dzeren antelopes, when attacked on the march, do not get into confusion, but follow the leader in a long, unbroken array, which many a general of half-disciplined troops might envy. Even the gazelles arrange themselves in something like military order when attacked by the lions of the Sahara. They form a hollow circle, in the centre of which the females and young are placed, while the defenders present lines of horns, like 2 row of bayonets, 
towards the foe. When troops form a hollow square, we admit the operation to be the result of calculation: why should a similar manœuvre by antelopes be ascribed to instinct only?

It is surely, then, allowable to conclude that signs of intelligence-of a faculty higher than instinct-are found among sheep, goats, and antelopes. 


\section{PACHYDERMATA.}

THE name pachydermata is derived from the Greek words which signify "thick skinned." Their teeth vary in strength and structure; the number of their toes also varies from one to five. Thus, the horse has only one, the pig two, the rhinoceros three, the hippopotamus four, and the elephant five. The diversity of these characters has induced naturalists to divide the pachydermata into several groups or families: that of the proboscides having a trunk; that of the cornmon pachydermata comprehending the rhinoceros, the hippopotamus, the pig, the tapir, \&c., and the family of the solipedes or solid-hoofed, as the horse.

Proboscides.-The elephants are the only representatives of this family-enormous animals, whose nose is developed in such a way as to constitute a long trunk, by which they seize the smallest substances, tear up trees, lift heavy burdens, and strike their enemies. Cuvier and others have estimated the number of muscles in the elephant at more than 40,000. These animals have two kinds of teeththe incisors, forming long tusks; and grinders, suited to vegetable food only. Their brain has numerous circumvolutions; the hemispheres contain three divisions, and the whole cerebral mass is a little larger than that of man. They have small sharp eyes and a very acute smell. 
The elephant is, as we shall see, one of the most intelligent animals.

The juments* are animals having the toes enveloped in hoofs, but not cloven. It is to this order that the horses, asses, and allied species belong. The commor pachyderms include the hippopotamus, rhinoceros, and tapir.

- Beasts of burden, such as the horse. 


\section{THE ELEPHANT.}

THE MUSICAL ELEPHANT.-THE COURTIER.-THE BOUQUET MAKER. -ITS HATRED.-ITS GENEROSITY.-ITS AFFECTION FOR CHILDREN.

"Av animal," says Buffon, " is a being purely material, which neither thinks nor reflects, and which, nevertheless, acts and seems to have the power of determining. We cannot doubt," he adds, "that the principle of determination is only a purely mechanical effect in an animal." Yet this same Buffon expresses himself thus about the elephant:"It has small eyes, but they are brilliant and keen, and distinguished from those of other animals by the pathetic expression of sentiment. The elephant turns the eyes slowly and with a gentle expression towards his master. $\mathrm{He}$ has a look of love for his guardian, of attention when he speaks, the glance of intelligence when he has listened to him, that of penetration when he wants to warn him. This animal seems to reflect, deliberate, think, and not make up its mind till it has looked several times at the object without hurry and without passion.

"The elephant, once subdued, becomes the gentlest and the most obedient of all animals : he attaches himself to his keeper, caresses him, warns him, and seems to know all that pleases him. In a little time the young elephant begins to understand signs, and to note the meaning of sounds, to distinguish between the tone of anger or of satisfaction, and 
to act in consequence. He never mistakes his master s word, receives his orders with attention, executes them with prudence, with haste but without precipitation, for his movements are always deliberate."

An animal which can note the meaning of sounds, can distinguish them, and act in consequence, is undoubtedly an intelligent being. The elephant and whale are the only animals having a brain absolutely larger than that of man. If the relative size of the bodies be considered, then of course man's brain is the largest.

Buffon adds, "Though the elephant has more memory and intelligence than any animal, he has a smaller brain than the greater part of them, compared with the size of his body. The nerves which extend through the elephant's trunk are so numerous that they equal in number all those distributed over the rest of the body. It is by a singular combination of the senses with the fine organisation of the trunk, that this animal is superior to others in intelligence, notwithstanding the mass of its body, and the disproportion of its shape. The elephant is at the same time a miracle of intelligence and a monster of matter."

All these contradictions, all these hesitations in Buffon, prove that the illustrious naturalist, partial to his false idea of the mere mechanism of animals, was forced, in spite of himself, to recognise their intelligence. But he does not see the true organ of intelligence, which is not the nerves, but the cerebral hemispheres. The pachydermata come immediately, in development of brain, after the carnivora, which are only separated from man by the monkeys. The law is confirmed here which says that intelligence goes with the development of the brain hemispheres. The elephant's brain has numerous circumvo- 
lutions, and, contrary to Buffon's idea, this organ is not smaller than that of the greater part of animals. It is proved that the rhinoceros, the hippopotamus, and the gorilla have, the size of their bodies considered, a smaller brain than the elephant. Let us add that this centre of action is admirably served by the senses. The elephant has the ear perfectly organised, and the hearing extremely fine. He likes music, easily learns to mark the time, and to move in step to the sound of drums. His smell is exquisite, and he likes perfumes of all kinds, and above all, fragrant flowers; he chooses them, picks them one by one, makes bouquets of them, and, after having relished the smell, carries them to his mouth, and seems to taste them.

The touch, the principal seat of which is in the trunk, is very delicate. He can trace, with the aid of this kind of hand, regular characters; can feel wholesale and touch in detail. The touch is so near the smell that these two senses co-operate together. The elephant has, if we may so speak, his nose in his hand.

With such a complete organisation, we must not be astonished at the elephant's marvellous intelligence. The Academy of Sciences has recorded some interesting facts, transmitted by those who kept the elephant at the menagerie of Versailles. This elephant seemed to know when he was laughed at, and avenged himself when he had an opportunity. To a man who had deceived him, pretending to - throw something into his throat, he gave such a blow with his trunk that it threw him down and broke two ribs.

Ancient writers have narrated many incidents showing the time during which elephants will remember an insult, and the singular modes of revenge which they will adopt. Most of these statements are probably true, but the impossibility 
of testing them must be our apology for omitting all mention of these marvels. We have so many trustworthy accounts of the doings of modern elephants, that we can easily dispense with the wonderful feats of the ancients. The mode in which the Indian elephant punished the tailor who pricked the animal's trunk with a needle, by drenching the offending man with water, is, probably, known to every English child, and further reference to this incident is needless. Captain Shipp had some reason for remembering both the strength of the elephant's memory and the unpleasant mode in which it retaliates upon a wrong-doer. The captain tried a scheme which he supposed would test the tenacity of recollection in the animal. $\mathrm{He}$, therefore, placed between two slices of bread-and-butter a thick layer of cayenne pepper, and gave the whole to the unsuspecting pachyderm. The creature's manner showed its disgust at the trick, but no attempt was then made to punish the perpetrator. About six or seven weeks after, the captain resolved to show himself again to the deceived animal. The elephant received the attentions of the visitor without the least sign of resentment, and the past seemed to be entirely forgotten. All at once, without the least warning, the unlucky and experimenting captain was deluged with a torrent of water from the trunk of the sly animal. The creature had clearly concealed its emotions, just as well-bred human beings do, and had carefully watched for the opportunity both of filling and emptying the trunk. Such an insiance of self-restraint in an animal is a strong proof that it possesses the faculties which give the power of selfdiscipline. A story somewhat resembling this is told of the elephant kept in the "Jardin des Plantes," at Paris. An artist was taking the portrait of the animal, and wished to make it 
open the mouth and raise the trunk frequently. To obtain this action an apple was, at intervals, thrown to the elephant. But to save a too great expenditure of apples, false throws were several times made, which had the effect of putting the trunk in the desired position, though irritating the creature exceedingly. At length the artist was about finishing the portrait, when the elephant filled his trunk with water, as if to drink, but, instead of so using the fluid, poured out the whole on the painter and his drawing. The revenge was complete, the artist being drenched and the work almost ruined. Mr. Broderip mentions a case in which a year elapsed between a trick practised on an elephant and the day of the revenge. The cheat in this instance was giving some nauseous food to the animal, which showed its resentment at the time by dashing its water bucket at the head of the offender as he hastily retreated. The following year the menagerie, of which this elephant formed a part, came to the same town, when the same person endeavoured to repeat the old trick. He did not escape this time, being caught up by the enraged animal, whirled in the air, and narrowly escaping with the loss of his coat-skirts.

In Madagascar, an elephant keeper, having a cocoa-nut in his hand, chose for fun to break this nut against the animal's head. The following day the elephant saw some cocoa-nuts exposed in the street before a shop; he took up one with his trunk, and killed the keeper with one blow of the hammer-like nut. This was literally practising the law of retaliation.

These few cases may suffice to show that, if a resentful memory and a designed punishment prove the possession of reasoning faculties, then we must grant these to the elephant. Such animals are, it may be supposed, always ready to resent 
wrong doing from one of their own species. A strong elephant at Bhurtpore snatched away a water-pail from a weaker neighbour, and then walked to the edge of a vast tank to get water. The plundered animal watched his opportunity, and rushing with all his might at the spoiler, pitched him over the edge to the bottom of the tank. How like a rational act was the whole operation!

The Versailles elephant was remarkable for his cleverness, which was such that he took off quite easily a thick leather strap to which his leg was attached, undoing the buckle and the ring, and when they tied this buckle with a cord twisted in a number of knots, he untied it without breaking anything. One night, after thus getting rid of his strap, he broke the door of his dwelling so cleverly that his keeper was not awakened by it. The animal passed into several courts of the menagerie, breaking the shut doors, and also the masonry when it was too small to let him pass. He thus went into the enclosures of all the animals, and frightened them so much that they fled to hide themselves in the most distant part of the park.

The stories of elephant sagacity might, indeed, fill a volume, for all their actions are marked, though in various degrees, by clear signs of this quality. In the year 1863 , an elephant was employed at a station in India to pile up heavy logs, a work which these animals will perform with great neatness and speed. The superintendent of the labour suspected the keeper of stealing the rice apportioned for the animal's food. The man, of course, protested with all the vehemence of a native against the charge, and bemoaned his hard fate in being exposed to such a cruel suspicion. It so happened that the elephant was standing by during the loud discussion, and, though no one supposed 
the creature understood the words uttered, the result was remarkable. The animal suddenly laid hold of a large wrapper which the man wore round his waist, and tearing it open, let out some quarts of rice which the fellow had stowed away under the voluminous wrapper. Further evidence was needless, either of the man's guilt or the elephant's sagacity. The animal had probably seen the roguish attendant place its food in his cloth, and had simply taken the opportunity of recovering its rights. So closely do elephants remember the signification of the signs which have been taught them, that they will instantly obey the gentlest signal, such as the lifting up of a finger or the slightest touch on their ears.

Bishop Heber tells of a malicious man who induced his elephant to kill a woman, by giving the sign of attack to the animal he was riding. Some natives had, however, witnessed the proceeding, and so clear was their testimony, that the man was hanged for the murder. The Mahommedan soldiers in the Mogul army trained their elephants to destroy the numerous small images of the Hindoo divinities. Of course, the soldiers pretended that the wise and theological animals had an innate hatred of idolatry, which could not be restrained! The Hindoo knew better, and divined that a secret sign was given to the well-taught beasts. Indeed, there is scarcely an act, from the killing of a man to the uncorking of a wine bottle, which these clever quadrupeds cannot perform; perhups to thread a lady's fine sewing needle might be beyond their power, but we are not certain. The Exeter Change elephant showed his reasoning powers in the following device, witnessed by Mr. Jesse. This gentleman was giving some potatoes to his huge pet, when one fell on the floor just beyond the sweep of the creature's 
trunk. A few inches behind the potato was a wall. The animal blew strongly against the vegetable. Of course this sent it further off still from the trunk against the wall, but the recoil brought the potato back nearer than before to the elephant, which then secured the prize. It seems absurd to suppose that the animal knew anything about action and reaction, but the deed performed and the result attained were just what reason might have suggested to a clever child.

An extraordinary instance of self-denial and recollection is described by Dr. Wilson, formerly Bishop of Calcutta. An elephant had become blind from an ophthalmic affection. A physician applied nitrate of silver to one eye ; the agony compelled the creature to utter a piteous cry, but the operation was so far successful that some degree of sight was recovered. It was proposed to try the experiment on the other eye ; but was it at all likely the animal would submit, having already felt the pain? However, the attempt was to be made, and the next day the physician visited his extraordinary patient. What followed seems almost beyond belief, but the testimony of educated and scientific eyewitnesses cannot be set aside. No sooner did the elephant see the physician, Dr. Webb, than he lay down of his own accord, and placed the head in a position which seemed to invite a repetition of the experiment. The operation was at once performed with the greatest ease. If all this is to be called mere instinct, then we may as well apply the same term to the noblest deeds of the human race.

The strong memory of the elephant has, doubtless, much influence in developing its natural sagacity. These animals have been known to repeat, with the greatest accuracy, exercises which had been intermitted for thirty 
years. Yet, after so long a period, a single old and once familiar word has put in motion the whole train of associations. These may have been the exceptions, the geniuses as it were, of the species; but even this is a supposition, and such animals may truly represent the intelligence of which the race is capable.

The elephant is vindictive, but grateful. A soldier of Pondicherry, who used to carry a certain portion of arrack to one of these animals whenever he took his pay, having one day drank more than was good for him, and seeing himself pursued by the guard, who were about to take him to prison, took refuge close to the elephant, and went to sleep. The guard tried in vain to draw him out of this asylum; the elephant defended him with his trunk. On the morrow the soldier, recovered from his intoxication, shuddered at waking to find himself lying near such an enormous animal. The elephant, who undoubtedly perceived his fright, caressed him with his trunk to re-assure him, and made him understand that he could go.

Some have doubted the generosity of the elephant, saying that he has an aversion for small animals. Major Smith relates a fact which completely contradicts this assertion. An elephant, publicly exhibited a few years ago in the United States of America, had a great affection for a dog. The spectators, trying to tease the elephant, amused themselves from time to time in pulling the ears of the dog and making it bark. One day this diversion took place near a barn in which the grave animal lived. As soon as the elephant heard his friend's voice in distress, he gave the planks a hard knock, and seemed astonished that the obstacle was not crushed under his weight. Then he struck with still greater force, made the planks fly into 
splinters, and looked through the breach he had made with such threatening gestures that the dog's tormentors found it convenient to decamp.

Dr. Franklin relates that he has seen in India a keeper's wife confide the care of a very young child to one of these gigantic creatures. "I was even much amused," he says,

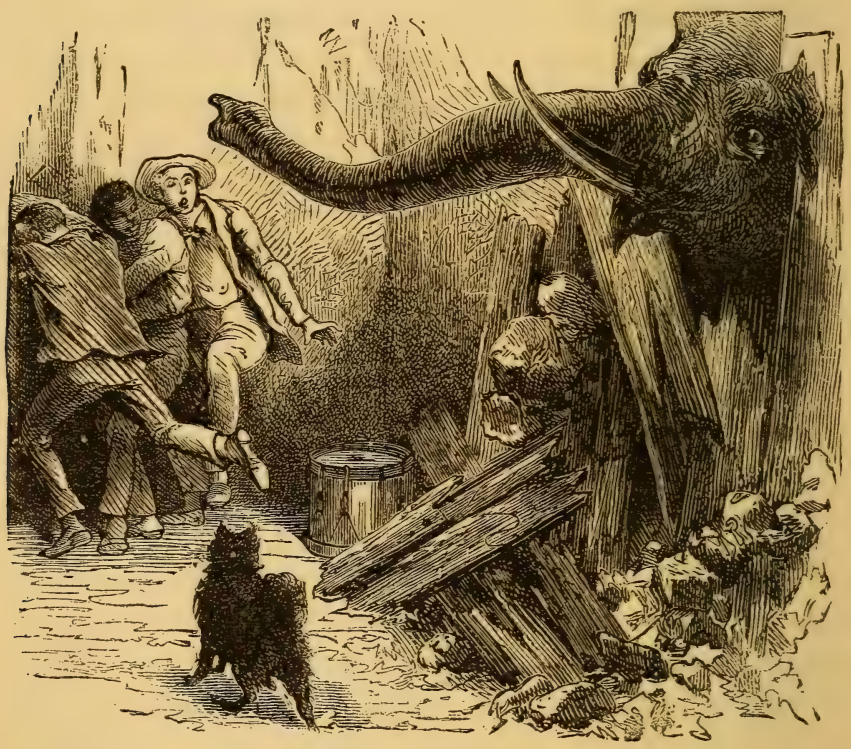

The Elephant protecting a Dog.

" in considering the sagacity and delicate care which this heavy nurse lavished on the child, in the absence of its mother, engaged elsewhere." The elephant had taken to its office in earnest. The child, who, like many others, did not like to remain long in the same position, and who wished everybody to be occupied with him, began to cry as soon 
as he felt he was left to himself. It even happened that he got entangled in the branches of trees on which the animal fed. The elephant then loosed him with admirable tenderness, either by raising him with his trunk or by removing the obstacles which could hinder the movements of the babe. If by chance the child had succeeded in dragging himself farther than the circle of the animal (for

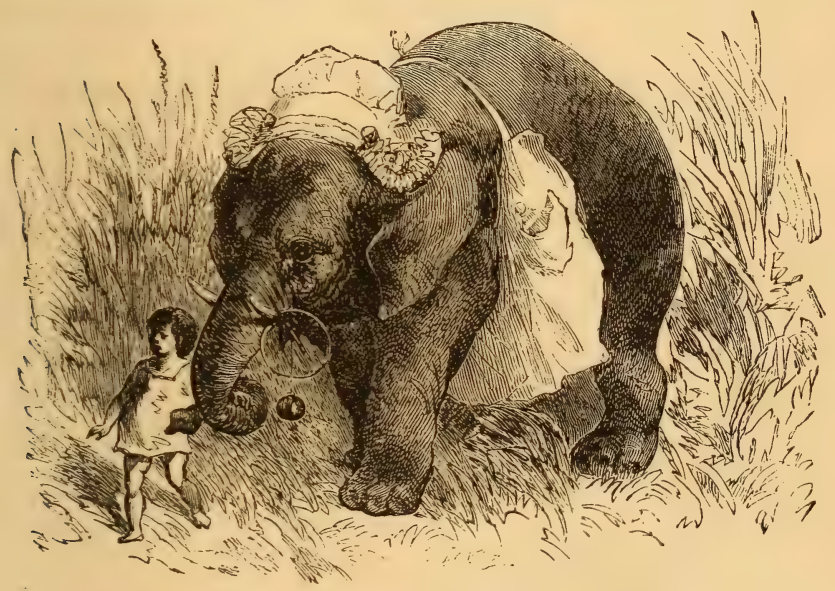

The Elephant acting as a Nurse.

the poor beast was chained by the foot), the elephant lengthened his trunk and brought back the child, with as much cleverness as gentleness, to the place from which the little romp had wandered. The docility of the animal to its master's orders was only equalled by its watchfulness over the child.

The elephant and the dog are perhaps the only creatures to which you can confide a trust, and which will fulfil it without being under the master's eye. 
The watchfulness of the elephant is sometimes shown to be accompanied with reflection. An artillery officer relates the following fact:-

"The train of artillery which was directed towards Seringapatam had to traverse the sandy bed of a river. It happened that one of the men seated on one of the ammunition wagons fell. The situation was most critical, and in a second or two the hind wheels would have passed over him.

"The elephant, which walked behind, perceiving the danger which the unhappy man ran, at the instant, and without an order from his keeper, raised the wheel with his trunk, and held it suspended in the air till the wagon had passed over the man without harming him."

Elephants, having been once taken in a hole hollowed out in their path, and covered with branches, are, when they have escaped from this trap, in a remarkably defiant humour. With their trunks they tear up a thick branch, "with which they go sounding everywhere before placing the foot, to see that there are no holes in their passage, in order to prevent being caught a second time."

Mr. Thomas Anquetil has published an interesting article on the Indian elephant. We extract from it the following passages:-

"In this country," he says, "it is the elephants which convey the teak wood from the place where it has been felled, in the forest or on the hills, to that where it is to be collected in floats of wood, on the banks of rivers, the two places often being several leagues apart. An elephant used to this labour will often continue it alone, even in the absence of his keeper. The latter leads him to the forest, sets him to work, and takes no more notice of him. The elephant 
arrives at the river bank with his burden, detaches, with the aid of his trunk, the iron hook, returns to the forest, again fixes the hook to the bands with which the trunks to be transported have been previously furnished, then starts again for the landing-place, and so on, not once failing in his arrivals, or slackening his pace, or delaying in his work till his keeper comes to seek him. He does not worry himself

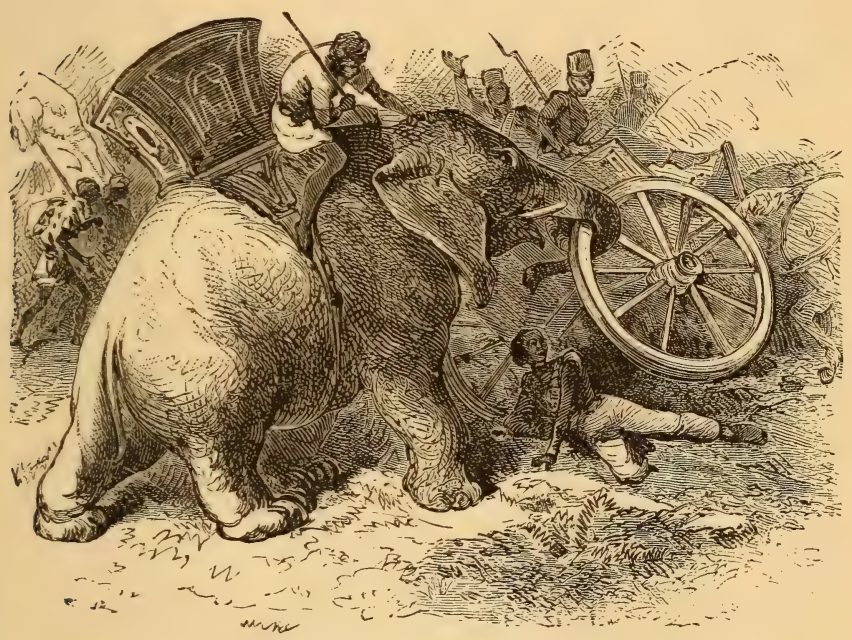

The Elephant rescuing a Soldier.

in the least during these long journeys by difficulties in the ground, or other obstacles of the same nature; he is able to overcome them easily, thanks to his extraordinary strength.

"The elephants used for riding mount with facility the steepest paths, and roads obstructed with branches or brambles; stones or splinters of rocks are taken away in the same cool and easy manner." 
The Indians had trained these animals to be their horses; the English employ them in moving machines of the greatest delicacy, power, and complexity.

"I was shown," says Anquetil, " near the ruins of Ava, where a Chinese community still exists, a juggling elephant. At fifty paces he never missed the palm-tree against which he had been trained to throw stones. At last, taking several thick iron rings, he threw them into the air and caught them on the end of his trunk, as the staff juggler, whom we see in our streets, does with his cane. This elephant also executed the egg-dance, and performed tricks of balancing and gymnastics. At last he uncorked, most cleverly, a bottle of soda-water."

The sacred books of India speak of an elephant called Khouny-Noor-or Black Diamond-cherished by the rajah to whom he belonged. Some rebels seized their sovereign, loaded him with chains, and took him into captivity, with Khouny-Noor. The latter showed no sign of discontent, but silently prepared his revenge. In a dark night he suffocated his keepers, broke his master's irons, fled away with him, and thus contributed to re-mounting him on the throne. The parties of Indian jugglers all possess an elephant accustomed to act the scenes which the greater part of our readers have probably seen in a circus or hippodrome.

Here is a curious story. A young Burman lord had married a second time. On the morrow of the wedding-day, in the morning, the new bride, surrounded by a swarm of followers, wished to take the air under the verandah, a kind of covered gallery which reaches round the dwellings of persons of rank. The favourite elephant of the master-that which the young lord usually rode-was walking at this 


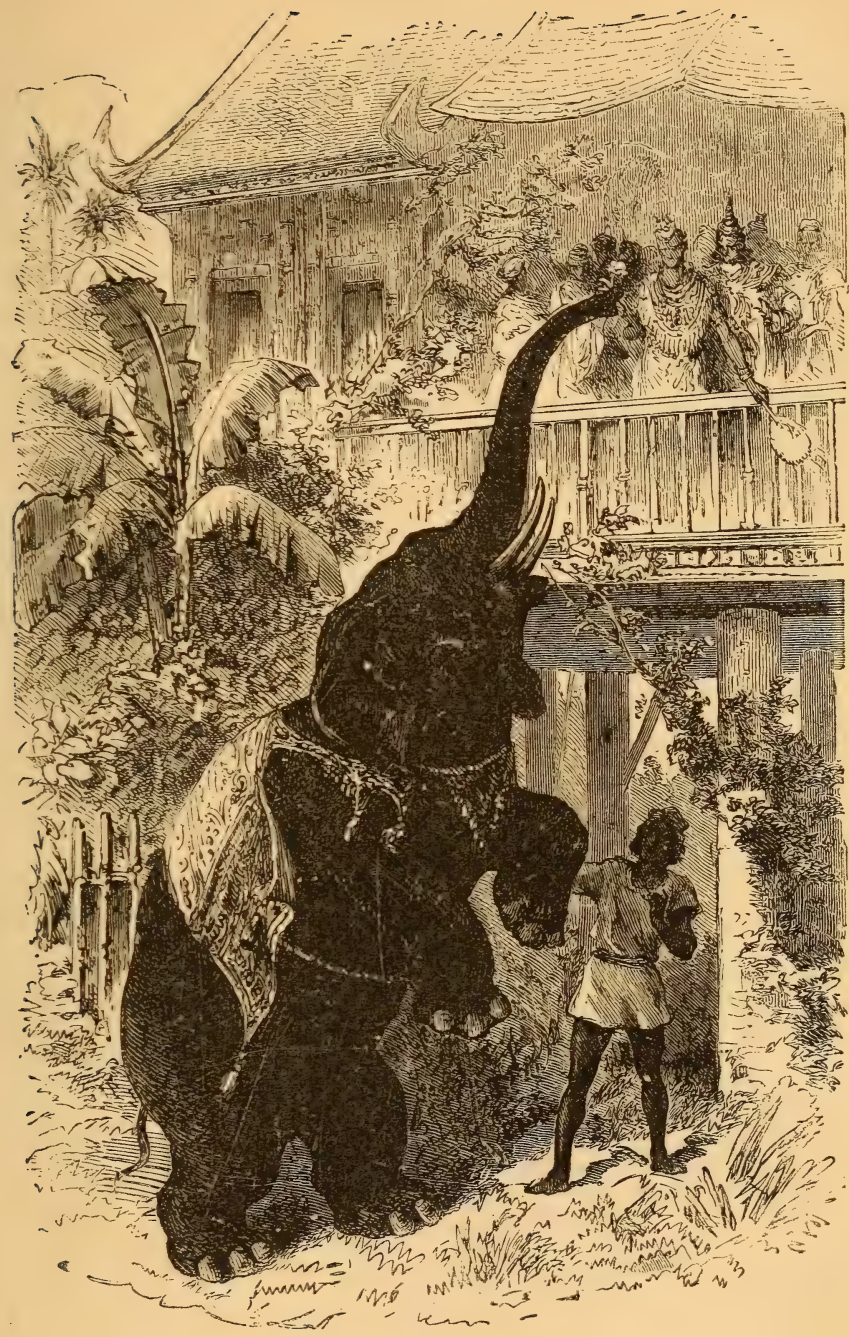

THE ELEPHANT BECOMES A COURTIER. 

mstant, under the care of the keeper, in a palisaded enclosure, in the centre of which the habitation was situated. Having noticed the presence of women, what did the creature do? He approached the verandah, leant delicately against a barrier of bamboos which enclosed a pleasure garden, picked the most beautiful, the freshest and most delicate flower, with the finger of his trunk, then shook his ears, gave an expressive cry, and showed significant attention in his gentle eyes; after which, raising his head and trunk gracefully, he lifted the flower to the level of the balustrade. One of the women stretched out her hand, the elephant drew back his trunk. The same movement being renewed several times, the master then wished to take the flower; the elephant did not now draw back his trunk, but he did not let go the flower. Upon this the queen of the fête advanced her hand tremblingly, and the extempore courtier then gave her his offering gallantly. Judge if he were not caressed from that time!

"I can guarantee the fact," said the narrator, "because I was there at the time." The person in question was a Portuguese, the eldest son of Cameratta, ex-cook, confidential steward, and factotum of the Burman emperor, and director of the custom-houses of the empire. The son himself was chief of the custom-house at Mandalay. 


\section{THE HORSE.}

TEACHABLE INTELLIGENCE.-MEMORY.-MILITARY HORSES.

THE noblest conquest that man has ever made is, without any doubt, that of the horse. Everything in this animal breathes out vivacity and energy. That need of continual movement, that impatience during repose, that nervous movement of the lips, that stamping of the feet, all indicate a pressing need of activity. The fulness of the skull, and the expansion of his forehead, show intelligence. The usual marks of the intelligent horse-one easily understanding his master's orders-are a well-developed head, eyes full and deep, jaws short, broad forehead, ears erect and diverging one from the other, and both eyes and ears very sensitive.

The horse has also a very strong sensibility. At the slightest excitement his breathing quickens, and the pulse becomes more rapid.

Not only is his brain developed and provided with circumvolutions, but he also possesses exquisite senses. He has eyes set in such a manner that, while he is feeding, he has very long sight in a horizontal direction, and distinguishes objects well during the night. His hearing is delicate, and he can easily collect sounds in his large, movable ear-cavities. This suppleness of the ear shows readily the character of the impressions made on the horse. 
A bold and very movable ear indicates activity. An ear often moved, turned to all sides, the horse looking to the right, to the left, and behind; an upper eyelid wrinkled, a look now fixed and now uncertain, indicate suspicion and fear. A horse that places its ears to the front, trying to scent the persons that approach, is docile, confidential, and disposed to receive caresses. The nostrils of the horse are full, and scent from a long distance odorous particles. His appreciation of delicate food is greater than in other herbivorous animals, the taste being more developed. The upper lip has great facility of action in feeding and picking up food. The skin is of an exquisite sensibility, and he is able, by wrinkling it, to drive off mischievous or troublesome insects. His voice, which is called neighing, is modulated by the sensations, desires, and passions. Five sorts of neighing may be noticed:-rst. That of joyfulness, in which the sounds get stronger and sharper; the animal bounds and rears, but has no intention of doing any harm. 2nd. That of desire: in this the accents are prolonged and deep. 3 rd. That of anger: this note is short and sharp; the animal tries to kick, to strike with his front feet, and if he is vicious, to bite. 4th. That of fear: grave and hoarse, seeming to come only from the nostrils, and, like that of anger, it is very short. 5th. The neigh of sorrow: it is a groan, a kind of suffocated cough, in which the grave sounds follow each breath. They are the most noble and the most intelligent horses, and also the most happy, that mostly neigh from joyfulness and desire.

Wild horses choose their own chiefs, which give the signal of departure. When a field is dried up these walk at the head of the column, and are the first to throw themselves into a ravine, a river, or an unknown wood. It any 
extraordinary object appears, the chief commands a halt. He goes to discover what it is, and, after his return, gives by neigh the signal of confidence, of flight, or of combat. If a fierce enemy presents itself that cannot be escaped by fleeing, the herd unite themselves in a dense and circular cluster, all heads turned towards the centre, where the young animals take refuge. It is seldom that such a manœuvre does not force the tigers or lions to make a precipitate retreat.

The powerful nature of the defence formed by thousands of hoofs may be estimated from the mode in which a single horse vanquished a bear. Bishop Newton, in his autobiography, describes a singular contest between a number of beasts collected in an arena by Frederick I. of Prussia. The king wished to provide some amusement of a fighting kind for the great Duke of Marlborough. As gladiators were out of fashion, animals were selected for combatants, and a horse, lion, bear, bull, tiger, and a wolf were turned into the enclosure. The ravenous creatures were soon engaged in a deadly struggle, the horse looking quietly on. The bear at length remained conqueror, and being enraged by battle and wounds, charged full upon the horse. The assailant was staggered by a tremendous blow from the hoofs of the attacked animal. Again the bear advanced, but then received such a sledge-hammer-like stroke that his jaw was broken. This at once decided the battle in favour of the horse. What was here witnessed on a small scale must often happen on the Savannah, when the wild horses form themselves in battle array.

These hordes, generally composed of several thousand individuals, divide themselves into many families, each of which is formed of a male and a certain number of mares 
and foals, that follow and obey the male with docility. The chief horse is the exclusive sultan; all the mares belong to him by the right of force; woe to the fool-hardy one that disputes with him his seraglio and authority. $\mathrm{He}$ defies him, fights him, makes him retire, sometimes makes him pay for his audacity by the loss of life. Often the conqueror pardons his foe, but might not be so generous if he could foresee that his vanquished enemy was only going to wait till age had given him greater force and courage to renew the combat. When the chief becomes old and loses his vigour, he then succumbs under the kicks of his rival, or dies from misery and shame.

What do the mares do when the furious rivals fight? They quietly graze, without appearing to take any interest in the issue of the combat, and place themselves afterwards, with docility, under the vanquisher.

When man ceases to direct attention to the animals in studs, they elect chiefs from amongst them, which are almost always old males. Amongst sociable animals, susceptible of becoming domestic, subordination is implanted by nature; they yield themselves to one; and this habit has for its object the preservation of the species.

The habit of marching in troops, and of manœuvring under the command of chiefs, renders the horse more fit than any other animal for the work of war, and man only profits by the natural taste of the horse, in training it for combat. These animals, finding in the life they lead in regiments an agreement with their general manners, enjoy themselves, and are happier than in any other condition of servitude. They acquire the knowledge of all the movements ordered, and are very soon capable, not only of understanding them, but also of directing the inexperienced 
horseinen who mount them. If the rider is carried off by a cannon-ball, the old war-horse does not desert the ranks, but continues to follow the chief of his file. Grognier reports that he has seen, when the columns of cavalry traverse a battle-field, abandoned horses follow, as far as their feeble strength would allow, the squadrons in which they recognised old comrades.

A feeling particularly belonging to the horse is emulation. Whoever has witnessed a horse race can understand the ardour, vehemence, and struggle for victory, which excite the energies of both horses and men. The animals have often endeavoured to hold their rivals back by the teeth. This will happen when the horses are left entirely by themselves, as on some of the Italian race-courses, where the horses run without riders. Both $\mathrm{Mr}$. Youatt and Mr. Martin, in their works on the horse, mention several cases of such determined, and, as it were, personal rivalry. Mr. Bell, in his "British Quadrupeds," reminds us of a horse which, finding himself losing, gripped the opposing racer so furiousiy that the race was stopped, and the jockeys forced to dismount. The proceeding was, doubtless, a complete violation of all racing laws, but it showed how entirely the horse entered into the spirit of the struggle. A similar instance is reported of the famous race-horse Forester, which, when running against Sir Tennison Shaftoe's horse, called Elephant, seized the latter by the jaw to hold him back.

The horse is endowed with a very strong memory. It has happened to many persons that when they have lost their way in the night, and let themselves be guided by their horse, they have recovered their road. Franklin reports that he had a horse who conducted him in a mountain country, difficult to pass. Every time that he lost his road, 
he left the reins on the animal's neck, which, abandoned to itself, never failed to regain the road.

Mr. Youatt boldly asserts that the horse "never forgets" a road he has once passed over. He mentions the case ot a young horse which went a journey of about thirty miles across a country which the animal had never seen before. In two years after, the rider set out for the same journey on the same horse, and towards nightfall got completely bewildered among the wild moorland tracks. What was to be done? The gentleman had heard wonderful tales about the memory of horses, but these recollections gave him little confidence now, as his own steed had travelled through that district but once before, and the night was dark and stormy. However, feeling the case desperate, the rider left the horse to take his own course. The animal set off in the darkness, and came in due time to the village where the journey was to end. The strong recollection which horses retain of places where they have been, and the tendency to stop at certain houses, or to go down particular lanes, must be well known to all who have much acquaintance with these animals. Their remembrance of persons is quite as strong as of places. Colonel Hamilton Smith was recognised by his old charger three years after the friends had parted company. The colonel was travelling by the mail-coach, and while the horses were being changed his attention was attracted by one. At the same moment the animal rubbed his head against his arm. The recognition was complete on both sides, being, however, more vivid and ready in the quadruped, for while the colonel was looking doubtfully, the horse showed an unhesitating recollection.

The intelligence of the horse would be still greater if, instead of limiting it to mechanical services, we took the 
trouble to develop it. The most sagacious horses are, in general, war-horses, because the soldiers in their leisure moments take the trouble to talk to the animals, and train them to all sorts of exercises.

The war-horse is a companion and a friend for the soldier. He hears the voice of man, partakes of his warlike passions, and neighs with fury against the enemy. Some may remember that in 1809 , the Tyrolese, in one of their insurrections, took fifteen Bavarian horses and mounted them; but in an encounter with a squadron of the regiment, these horses escaped at a great gallop and carried their riders, in spite of all efforts, into the ranks of the Bavarians, where they were made prisoners.

Perhaps this rejoining of their old companions was mainly caused by the strong affection horses often have for animals of their own species with which they have been long associated. Friendship is not limited to the human race; cynics even insinuate that it is by no means common among men. Perhaps the cynics are entirely wrong; but it is, however, certain that horses have shown attachment for each other. Mr. Jesse mentions two Hanoverian horses who had long been associates in a brigade of artillery. One was killed in battle; the other received his usual food after the fight was over, but, instead of eating, kept looking about as if searching for his lost companion. No inducement could prevail on him to touch food, nor would he pay the least regard to the other horses near. The soldiers tried every scheme to disturb the animal's old recollections, and to awaken new impressions. The men saw that a trained and valuable horse was likely to perish for want of it usual food, and the old campaigners taxed their wits to discover some mode of forcing the animal to eat. All efforts were useless, and the 


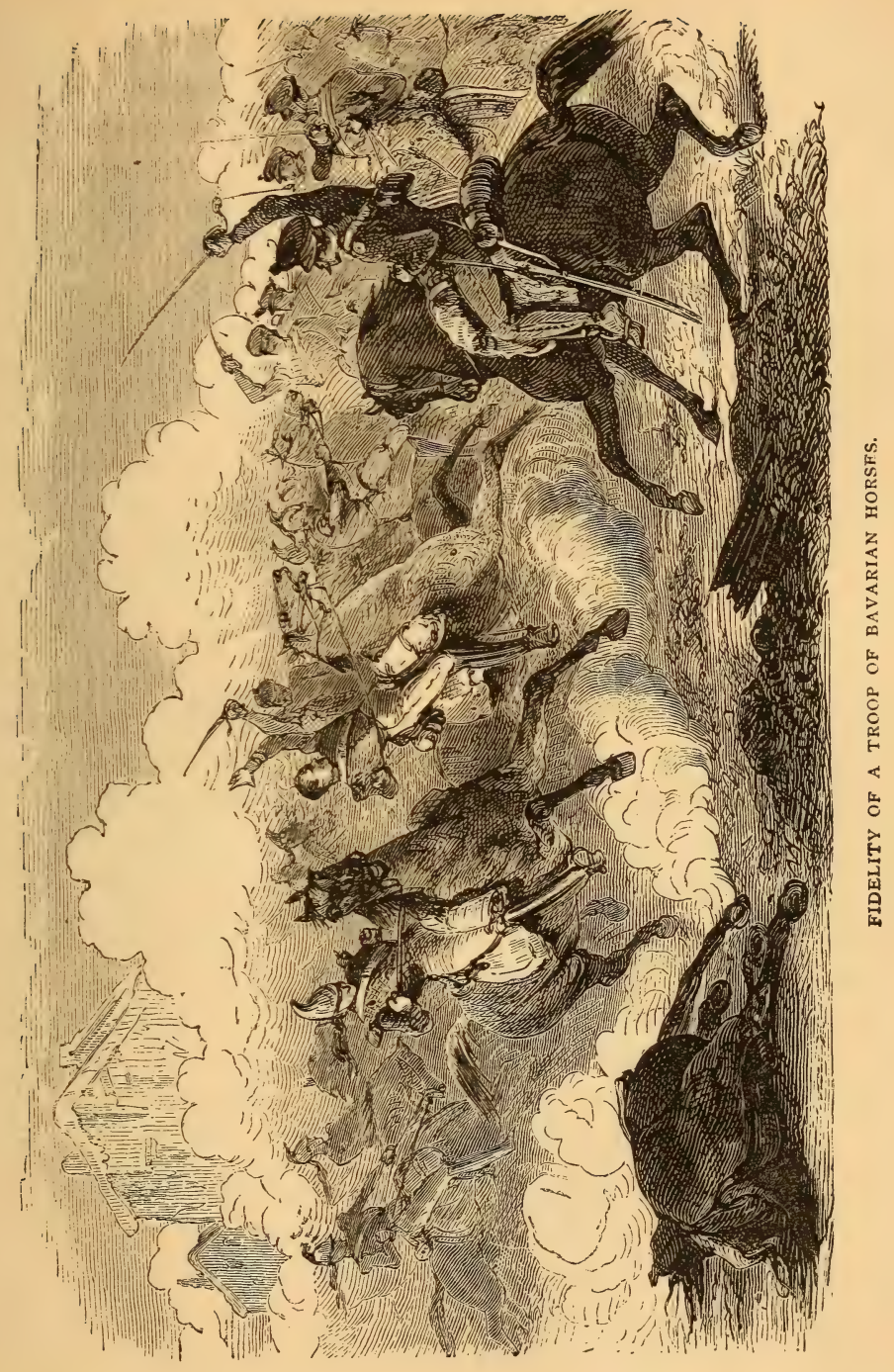



horse died of starvation, or rather, as we may justly say, committed suicide from grief at the loss of an old friend.

Horses will not only bemoan lost companions, but sympathise with and endeavour to aid their living associates. The mere statement of this will seem absurd to some, and they will laughingly ask whether we believe in the fourth voyage of Captain Lemuel Gulliver? Our belief is founded upon evidence ; and such a basis of opinion is, we humbly presume, sought even by those who seem ever eager to reject all proofs of animal intelligence. Mr. Watson, in his work on "The Reasoning Power in Animals," mentions the following:- "A gentleman was one evening in the full enjoyment of a pleasant dinner-party in his own house. It so happened that a glass-door opened from the dining-room upon the lawn. Pushing open this door, a most extraordinary and unbidden visitor entered the room. Starting up, the amazed company beheld a quadruped which had never entered that room before. The gentleman advanced and recognised one of his favourite mares, which, undaunted by the blaze of light and the crowding round her of the astonished guests, showed by voice and manner some strange emotion. Her master went up to the animal, which trotted off, uttering a peculiar cry. It was determined to ascertain the cause of the mare's strange conduct. She was followed to a field, and the motive for her unwonted behaviour was quickly ascertained. Her foal had got entangled in bog and briars, and the alarmed mother had adopted this effective mode of obtaining aid." A somewhat similar incident has, in a previous chapter, been told of a sheep, and in both cases the appeal for human help had a rational motive, and was prosecuted in a rational manner. Many 
cases of the same class could easily be given, but the mere accumulation of similar facts is hardly desirable.

Some of the ingenious feats of the more clever horses have a close resemblance to human actions. Take the following case, narrated by Mr. Smiles in his "Life of Rennie, the Engineer:"-A horse, called Jack, was one among many employed at the erection of Waterloo Bridge. The horse was accustomed to draw the stone-trucks along a tramway to the places where the stones were required. A beer-shop was, of course, opened near the works for the special use of the 'navvies' and other workmen. The driver of Jack's truck was an honest sort of fellow, named Tom, who had one special weakness-an inability to pass the beer-shop without taking ' a little.' Jack was so accustomed to this, that, though a restive animal, he waited contentedly till Tom came out of his own accord, or till the appearance of an overlooker startled the man into activity. On one occasion, however, when the superintendents were absent, Tom took so long a spell at the ale that Jack became restive, and, the trace fastenings being long enough, the animal put his head inside the beer-house door, and seizing the astonished Tom by the collar with his teeth, dragged the lazy man out to the truck. Every man there understood the action of the horse, and great became the fame of Jack amongst the host of workers.

Mrs. Lee mentions a horse which, having to cross an opening on some planks, and these having become slippery by frost, scattered with its feet some loose sand lying near over the ice-covered timbers, and thus secured a rough surface and a firm footing. This is precisely what a man would have done under the circumstances.

Mr. Jackson, in his work, "Our Dumb Companions," 
gives the following instance, illustrating the sagacity of a horse :- "The animal had been carelessly shod, and, probably, suffered pain in consequence. The creature seems to have been quite aware of the proper remedy, for a few days after the shoeing operation the farrier was amazed to see the horse approach the door of the workshop, and hold up the hoof. An inspection soon showed the nature of the fault, which being rectified, the animal went off satisfied." The clever manner in which this horse escaped from its meadow must not be passed over. Having no means of unlocking the gate, he had actually lifted one end off the hinges with his teeth, and was thus able to get through. The horse mentioned by Lord Brougham, in his "Dialogues on Instinct," which, having watched the men pumping water into his trough, raised the water himself by working the handle up and down with his teeth, was a first-rate imitator, or a fair kind of reasoning animal. The general conclusion, therefore, seems to be that the more we become acquainted with animals, the more do evidences of their intelligence multiply, 


\section{THE ASS.}

We liked the donkeys very much in our youth, and we shall still be happy in our older days to render justice to a misunderstood animal, an honest beast, and a devoted companion of the poor traveller. The ass is hated, mistaken, blamed, badly fed, tugged to the right, to the left, turned upside down, beaten by all children, and only gathers the thistles of life. How much has this patient animal lost in form, since he delighted in his wild state! His character is equally changed: he is no more a lively, wild animal, but a poor slave, stupefied by the kicks of an unpitying master.

Toussenel, who is rather inclined to describe animals according to the common ideas entertained about them, seems to have taken literally " the folly" and "the gross ignorance of the ass." To him the ass symbolises, more especially in France, the water-carrier, who is his companion in labour. The native of the Auvergne mountains, he says, does not shine precisely in delicacy of language, elegance of manners, or nicety of eating. Toussenel would see a likeness between the ass and the Auvergnat, as he would between the gentleman and the Arabian steed.

It is not to-day that the ass and fable have first been united; ages ago they were pleasantly joined in many a witty analogy.

The Holy Scripture treats much of the poor beast on which the Saviour was mounted. The ass is venerated 
because it carried on its back a cross-the emblem of tribulations.

As it likes thistles and thorns, it is compared to a philosopher who supports with calmness all the bitterness of life. The ass is, to some, a type of good men who renounce the pomps and vanities of the world. It has been remarked that the prudent beast does not traverse willingly the dangerous passes where it has stumbled. It is thus likened to the wise man who fears to fall again into the snare in which he was taken. The ass has little confidence in new waters, and has to be urged before drinking in unknown ponds; therefore some have made it a model of prudence, and others a type of those who oppose all change, all new ideas, and the right of free examination!

After having compared the ass to a water-carrier, Toussenel sees between it and the rough peasant a great resemblance. The spirit of obstinacy, he says, and of systematic opposition to new ideas is, in reality, the dominant passion of the donkey! The ass who is the emblem of the rough peasant, and of the boorish hater of novelty, errs above all by disuse of its intelligence. It is not so much the love of the old customs that binds it, but the horror of the new! Toussenel admires the ass, and the peasant his image, because they are both admirable for their soberness, their constancy in work, and their resignation in poverty; but he should not make virtues of their faults, because he knows that it is through want of elevation in their aims that the peasant and the ass support their condition so patiently. It is very easy to say that, my dear professor, some may say; you yield too easily to your sympathies or antipathies.

The ass is neither a dirty water-carrier, nor a rough 
peasant, nor an idler in intelligence, nor a being without elevation! It is, on the contrary, an exceedingly clean animal, which continually reproves man for thrashing him. See him rolling on the grass, on the heath, on ferns; he does not wallow, like the horse, in mire or water; he even fears to wet his feet, and turns away to avoid the mud.

The ass, in infancy, is a pleasant fellow, full of gaiety and tricks. He only loses his gracefulness by ill-treatment, and the miserable life he is forced to live.

No hairy animal is cleaner than this, and he differs in one respect from many of his betters-the donkey never has any fleas!

The donkey has not an idle intelligence. No being is more reflective, more prudent, or more sober. Now, sobriety is known to be the strength of intelligent people. Look also at its strong head, its eyes full of reflection set deep in their orbits, covered with large and bushy brows. But listen to Buffon, who is never more eloquent than when he has seen what he describes: "The donkey attaches itself to its master, although it is maltreated. It smells him from afar, and distinguishes him from all other men. It also knows the places it has inhabited, and the roads it has frequented. It has good eyes, admirable smell, an excellent ear, which has contributed to its being put among the timid animals, which are all said to have very fine hearing and long ears. When it is too much tormented, it opens its mouth, and draws back its lips in a very disagreeable manner, with a mocking and derisive air."

The ass loves music. Here is an instance. Dr. Franklin. says that a donkey of Chartres was in the habit of going to the castle of Guerville, where they often had music. The proprietor of this castle was a lady, who had an excellent 
voice. Every time she began to sing, the donkey never missed coming near the windows, and there listened with the greatest attention. One day, a piece of music having doubtless pleased it more than all it had previously heard, the animal quitted its ordinary post, entered the room without ceremony, and began to bray with all its might!

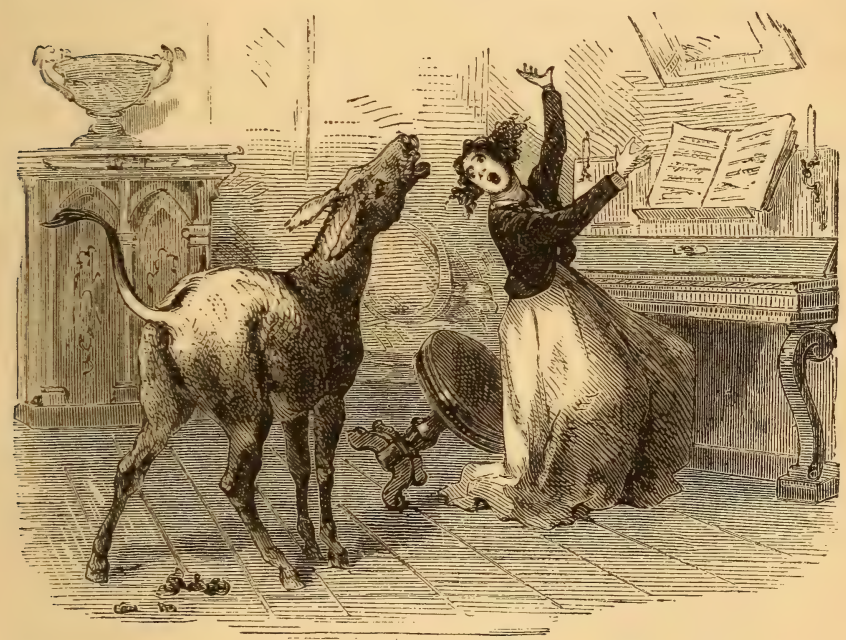

A Musical Connoisseur.

This fact seems to contradict the opinion of Erasmus, who declares that this cross-bearing quadruped has very little inclination for music. It is true that he adds in behalf of his protégé this extenuating circumstance, that if the donkey contributes little to harmony during its life, it generously serves it after death, by furnishing the best skins for making the large musical cases, and the bcst material for clarionets ! 
The memory of the donkey is remarkable. The fol. lowing account was communicated to many by Lieutenant Alderson, of the Royal Engineers. In March, 1816, an ass which belonged to Captain Dundas had been embarked at Gibraltar, for the island of Malta, in the frigate Ister. The vessel which carried it having touched some sandbanks near Cape Gata, the donkey was thrown overboard, to give it a chance of regaining land. The lot of the poor animal was deplorable, for the sea rolled so terribly, that a boat which had left the vessel was lost. Some days after, when in the morning the gates of Gibraltar were opened, the donkey presented itself for admission into Mr. Week's stable. Valiant, such was the animal's name, had before occupied this place. Great was the surprise of the honest merchant. - He imagined that, for some reason or other, the donkey had never been placed on board the Ister. On the return of the ship the mystery was cleared. Not only had Valiant swam safe and sound to the shore, but, without guide, without compass, without a geographical map, had found its way from Cape Gata to Gibraltar, a distance of more than 200 miles, over a country it had never crossed before this adventure. It was a mountainous country, difficult, and intersected by streams of water. The short time in which this journey had been accomplished showed that the animal had not gone from the right road.

One author says, with much reason, that " the contempt which certain fabulists have heaped on the character of the donkey is more absurd than the respect which our humorist Sterne had for this creature." "I cannot," said he, "strike this animal. There is such patience, such resignation written in its looks and its behaviour-all that pleads so much for it-that it disarms me. I do not like to speak 
to it rudely. When I meet it, no matter where, in town or in country, attached to a wagon or under baskets, in liberty or in servitude, I have always something civil to say to it, and my imagination then endeavours to comprehend its answers by the expression of its features."

Could we see daily before us the beautiful asses of Spain, Arabia, and Persia, some attempts would certainly be made to improve the breed and general condition of our degraded British donkeys. The highly-bred asses of Persia are said by travellers to be "the handsomest animals in the world ;" and, instead of being left to the neglect of the lowest and most ignorant classes, are eagerly purchased by the noble and luxurious. Among all Asiatic people the animal was held in a respect which we can hardly understand, and which places all our proverbs in direct antagonism to those of the East. To liken a man to an ass is, with us, a term of the highest contempt; but when the dying patriarch Jacob wished to describe the fertile regions to be allotted to Issachar, he could select no phrase more descriptive than the words "strong ass." * The wild asses of Central Asia preserve to this day their ancient fame for courage, energy, and discipline. The sight of a vast troop of these active creatures, marching under the guidance of leaders, will scatter all our Western notions about an animal which, having degraded, we now despise.

But even our common "donkey" does sometimes amaze his owner by some feat supposed to be far above his powers. A Yorkshire farmer, quoted by Mr. Jackson in his "Dumb Companions," declared that, whenever a trick was played by his animals, the demure-looking donkey was sure to be

- Genesis xlix. 14 
the ringleader. Some horses and a donkey were one day secured in a meadow, next to a field of oats. It was soon clear to the farmer that the animals had discovered some mode of getting into the ripening corn, and, a watch being set, the trick was discovered. The donkey was seen to unfasten, with his teeth, the spring-catch of the field-gatea work which none of his nobler associates would have attempted. The horses seemed perfectly aware of their companion's superior abilities, standing quietly by until the ass finished his self-appointed task.

This animal sometimes combines a laughable obstinacy with intelligence. Some recent writer tells the following story of a Lancashire donkey belonging to a carrier. The master was accustomed to stop at a public-house for ale, a little of which was always kindly given to his quadruped companion and fellow-worker. Matters went on nicely for some time; but men, whether politicians, theologians, or carriers, are liable to change opinions and habits. The donkey's owner became a teetotaler-a conversion which the animal would have tolerated had it not diminished his own enjoyment. The carrier could no longer call for ale, therefore had no further occasion to call at the public-house. But there were two opinions on this point. When the carrier came to the well-known spot, "Forward" was his motto; but the donkey drew up deliberately, as of old, not being aware of any change in his master's mind. The carrier applied the usual arguments to the animal's skin in vain, to the intense delight of the publican, who held teetotalism to be the eighth deadly sin. What was to be done? Budge a foot the donkey would not without his usual sip of ale, and the carrier was too kind-hearted to belabour his old friend when he saw the state of the case. But it was provoking 
that he, a conscientious and determined teetotaler, must actually purchase ale to please his own ass. The man had also the additional mortification of remembering that he had formed the habit of the animal by his own act and deed. The dispute ended by the donkey getting the ale whenever he passed that way. It was a sad case of animal degradation, doubtless ; but, though the ass sunk as a moralist, he rose as a genius. It was an honour, thought some, to have such a donkey in the district. 


\section{SWINE.}

Some, on reading the heading of this chapter, may think that we ought to have passed over an animal so utterly wanting in dignity. We will not argue the question here in reference to our ordinary pigs, but only ask our critic to have a little talk with some hunter who has stood the charge of the wild boar in a Russian forest. The inquirer may chance to find the said hunter full of deep respect for the gallant bearing of the tusked foe. Swine are connected in structure not only with the pachydermata, but also with the ruminants and carnivora. But our main object being to exhibit the intelligence, and not the complex anatomical relationship of animals, we must omit further reference to the exact position occupied by the family of swine. Perhaps few would expect many proofs of either high instinct or low reason in these animals. Those who are best acquainted with their habits claim for them qualities which are by no means commonly ascribed to them. There can be little doubt that pigs possess a strong memory. The best proof of this is the readiness with which they will find their way back from new to old haunts, from which they have been taken. Among the instances of animal sagacity recorded by Mr. Watson is that of two pigs bought by a farmer at Reading market, to which they had been brought from a distance of some miles. The two animals were taken to the farm of the purchaser at Caversham, about two miles from Reading. Next morning there was a 
great cry ; the pigs were missing, and for some time nothing could be heard of the fugitives. At length news came that two pigs had been seen swimming across the Thames. The next bit of intelligence traced them to Pangbourne, and the result was that the determined animals presented themselves at their old home after a journey of nine miles through cross roads and lanes. These pigs clearly acted in concert, escaping together, swimming the deep river in close companionship, and both entering their former home at the same time. These "path-findings" are by no means rare with pigs, many similar cases being mentioned by authors.

The obstinacy of the pig is almost as proverbial as that of the mule, but Bernard Gilpin gives the animal a certificate for docility. This writer affirms that, with kind treatment, a pig may become an "orderly, docile animal," and winds up by declaring that the animal may "be led with a straw." Mr. Gilpin does, indeed, admit that the pig "may have a degree of positiveness in his temper;" but may not that much be said of many men-ay, and of women too? In truth, if the pig were not docile, how could he ever have become learned? But we have all heard of the "learned pig," which did not reach, perhaps, the heights of syntax, but had certainly mastered the elements of etymology. This pig had not only learned the alphabet, but could pick up cards having the letters on them, and place them so as to form words. It was not a high degree of learning, some will say; very true, but remember the pupil was a pig. Even such a degree of scholarship could not have been attained by an animal with a feeble memory and without powers of combination. Nor must it be forgotten that there have been several learned pigs; so that the honours of the race do not depend solely on the exceptional 
genius of one individual. A learned sheep is a marvel yet to arise; no learned ox even can be produced, though old stories do hint something about a speaking ox. But we have our serious doubts on the point, and require more evidence before believing in these heathen miracles. At present, then, the advocates of the swine may rely on the past performances of a succession of learned pigs.

What shall we say about the intelligence of the pig which learned by a little teaching to rival and even to excel the pointer in the art of pointing at game? The feats of this keen-scented sow, and the tact with which she would stand at birds which the dogs had missed, may be read in Bingley's "Memoirs of British Quadrupeds." A good scent may have aided this animal, but she must have possessed the capacity for receiving and retaining instruction. This instance of a peculiar aptitude in the pig does not stand alone; others may be found in the work of Mr. Youatt.

Many persons can scarcely be brought to listen to evidence of intelligence in an animal which they deem degraded by its love for dirt. Here is another great mistake. The pig is naturally a very clean animal, and would never sleep upon dirty straw if it could obtain clean. Thoughtless and negligent men shut up the animal in a wretchedly kept sty, and then wonder at its unclean habits. As well might we say that man is naturally fond of dirt, because neglected children are coarse and low in behaviour. The pig is seen sometimes to wallow in dirty pools, but this is done to cool the skin, and it is not the animal's fault if the only water it can find is a muddy pond. The disgusting state of many farmyards is such as no pig would tolerate if it had the direction of affairs. 
It is not to be expected that the natural quickness of these animals should be much developed in a sty. When large herds are allowed to wander, under the management of keepers, in the beech and oak forests, their acuteness and energy are evident enough to all who can watch their habits. The wild species have little opportunity of showing any quality except their courage, which man calls ferocity. Man will charge his human foes with sabre and bayonet, and sweep their ranks with rifled artillery, without deeming himself a savage. But when a hunted boar turns in desperation upon his armed pursuers, and gores horse and man with his tusks, this is called ferocity. It is, in reality, only "the noble art of self-defence," as practised by an assaulted animal. Thus man can only, in general, note the intelligence of the wild species of swine as it is displayed in battle against him.

The Babiroussa,* or Asiatic double-tusked swine, are but little known at present, but the peccaries of South America show an almost military skill in combining to resist attack. Often when the hunter has shot several of these wild pigs, he finds himself surrounded by a rapidly-gathering host. If no tree be near, the man perishes by a thousand tusks, and even should he ascend one, the peccaries will wait for hours round the tree until hunger compels them to seek for food.

The above few remarks may serve to show that neither the domesticated nor the wild swine are so deficient in intelligence as many have supposed.

* Hog-deer. 


\section{THE CARNIVORA.}

Among animals, those whose appetite leads them to obtain their nourishment from flesh exhibit a larger amount of intelligence. "Nature has given them," says Leroy, "very fine senses, with great force and activity, necessary to them, because, having to nourish themselves by warring continually with other species, they would soon perish from hunger if possessing inferior or even equal powers." With Leroy, we admit the work of the senses in the intellectual manifestations. We have already declared that a large development of the senses could supply even a want of perfection in the brain, in the same manner that a more lively instinct will give energy to indifferent powers of intellect; but the senses, the source of instinct, are only the messengers of the intelligence. If we believed to the letter the law of intelligence drawn from the development of the brain hemispheres, we should perhaps find some contradictory statements respecting the carnivora, which order contains animals extremely intelligent and equally stupid. The brain is not the less the organ of intelligence. Leroy has studied so profoundly the intellectual faculties of this order of the animal creation, that we cannot resist the desire of referring to his chapter on the intelligence of the wolf and the fox. It is not, says he, entirely to the fineness of their senses that animals owe the vigour of their understanding; but the lively interests, such as 
those of overcoming difficulties and avoiding perils, which keep in practice the power of feeling, and impress on the creature's memory the multiplied facts which all together form the guides of its conduct. Thus, in places distant from all habitations, and where game is abundant, the life of carnivorous beasts is limited to numerous similar and simple actions. They pass successively from rich plunder to sleep. But when man places obstacles in the way of satisfying their appetites, when he prepares pit-falls under the steps of animals, and puts all kinds of snares in their way, keeping them in continual fear, then a powerful interest forces them to be careful.

These obstacles offer the animal two ways of acting, which it will be as well to consider separately. The one is purely natural, very simple, and limited to few sensations; such is, probably, in certain respects, the life of the savage. The other springs from education, and is more active and full of interest and of fears, which in some measure represent the agitations of civilised man. The first is generally the same in all carnivorous species. The other varies more in one kind than another, by reason of the organisation being more or less happy. The two modes of life must be compared together. 


\section{THE CAT.}

CAN a creature possessing the highest carnivorous propensities be endowed with any intelligence at all? Such a question might be expected by some from one of the most fanatical members of the non-fighting club, but cannot be seriously proposed by any one who has studied the characters of great warriors. Was Cæsar an imbecile? Was Alexander a stupid? Why, then, should warlike and predacious animals be deemed inferior to ruminants or rodents? We do not intend to examine how far the larger cats, such as the lion, tiger, and leopard, may be distinguished for intelligence, our object being to ascertain the capacities of the common domestic mouser. Many readers are aware of the superstitious awe in which cats have been held by various nations in past times-a feeling rather opposed to the notion of the animal's stupidity. It has even been credited with supernatural powers, and was once regarded as the most able agent of the witch in her awful incantations. These women were supposed, on certain important occasions, to be able to transform themselves into cats, for the greater convenience of holding their dreadful revelries. Even so late as the year I7 8 the sheriff of Caithness instituted a solemn judicial inquiry into the extraordinary and unwarrantable conduct of a host of cats, alleged to be witches in disguise. The unhappy complainant in the investigation was a Mr. William Montgomery, who deposed to numerous 
instances of malicious persecution on the part of the witchcats. Puss has, therefore, borne an important part on the "night side" of human nature, and many persons may agree with Sir Walter Scott when he declares cats to be "a very mysterious kind of folk." But as our views respecting these animals are much more prosaic, let us consider a few wellattested facts illustrating the intelligence of the race.

When an animal learns to open the door of a closet by lifting the latch with its paws, we may safely admit that observation of the mode in which the door was opened by the inhabitants of the house must have been combined with some degree of reasoning. This feat has been performed by cats when any projecting ledge has given them a standingplace while the foot was lifting the latch.

The cat's love for the places to which she has been long accustomed is well known, and the journeys sometimes undertaken to regain the old home are proofs of the animal's perseverance and acuteness. Mr. Jackson gives a little history which illustrates both the affection of the cat for her young and her strong attachment to a former abode. This animal had been removed to a new house, and having kittens soon after, it was naturally thought she would become accustomed to the place. For a time, Puss submitted to destiny, attending upon two kittens with all due care. One day the cat and one kitten disappeared; the one left behind could feed a little. But where had the mother gone? In two or three days, as was afterwards found, she and the kitten appeared at the old house in a deplorably weak condition. Being well-treated, she soon recovered, and actually returned for the other kitten, which, out of pure pity and admiration for her perseverance, she was permitted to lead away. Mrs. Lee mentions a cat which 
found its way back to a former home across two rivers. The distance to be travelled was only about five miles, but the energy evinced by such an animal in crossing the streams gives the incident its singular character. The determination to return, and the local associations, must have been strong in this cat, as she had been closely shut up for some days in the new home. In this case memory must have been as strong as the energy was decisive. These instances are not uncommon, and if our object were simply to accumulate facts, a very large collection might soon be made, all proving the strength of memory in cats. In one of these a cat made a journey of forty miles, carrying not one but two kittens with her the whole way. Mr. Jesse has recorded this walking and carrying performance of the cat.

Some of the accounts given of the recollection of persons by these animals are as wonderful as those relating to places. Crimes are even said to have been thus detected. In a dog this would not very much surprise many, but we do not expect such exhibitions of superiority in the mouse-hunter. Mrs. Lee describes the mode in which the agitation and fury of a cat, in the presence of suspected murderers, led to the discovery of evidence which brought the case home to the criminals. The mistress of this cat was found murdered in her room, the only living inhabitant of the apartment being a large cat, which remained motionless on a shelf, notwithstanding the crowds who poured into the room on the discovery of the deed. At length two or three men entered, towards whom suspicion already pointed. When the cat saw these, it darted in a fury from its place of refuge, sprung towards the new comers as if about to attack, and then darted, as if frightened, under the bedstead. The extraordinary conduct of the animal told upon the superstitious 
fears of the ruffians, whose confused behaviour led to further investigation, and to the consequent punishment of the guilty. There is nothing so very astonishing in all this, if we admit a strong memory in the cat. An animal accustomed to sit quietly by its mistress would naturally have all its emotions roused by the violence accompanying a murder. Having memory, what more likely than the excitement shown when the murderers again presented themselves? Other instances of this kind are given in various works.

These animals, when well treated, will often show a remarkable affection for creatures towards which, in general, they manifest a marked hostility or dread. Cats have exhibited the most laughable friendships for dogs, refusing to sleep except between the paws of their canine associates. This has often been seen when the two animals have grown up together, and when the dog has never been incited to attack the weaker animal. All this shows a power of adaptation to circumstances, and a capacity of being trained, which can hardly belong to mere instinct. Still more surprising, perhaps, is the change of natural habit which is shown when the cat becomes fond of a bird. If there be one little thing more likely to attract Puss than even a mouse, it is the fluttering movement of winged life. Yet pet cats and pet canaries have been known to live on the most loving terms together. This must have been the triumph of a trained intelligence over instinct. In one case the two lovers were cat and goose, and the bird never seemed more happy than when waddling about with the feline friend seated on her back.

When the cat conquers her natural dislike to water in pursuit of fish, we have another instance of the plasticity of the animal's faculties. A liking for fish as food seems 
instinctive in the cat; the dislike to water is equally instinctive; but sometimes this latter tendency is completely over. come for the sake of gratifying the former. Cats have keen known to plunge into water in pursuit of fish with all the zeal of otters. Even one such case shows how animal habits may be modified by the law of circumstances. It thus appears, then, that we can trace, even in cats, the workings of intelligence acting in combination with the impulses of instinct. 


\section{THE WOLF.}

THE wolf is the most robust of the carnivorous animals in the temperate climates of Europe. Nature has furnished it with a great voracity and many wants, in proportion to its force. It possesses very fine senses, a piercing eye, and a nose which aids in detecting everything that presents itself. When in good practice, it learns by these senses the relation which objects have to itself. There is a vast difference between the gait of a young and inexperienced wolf and that of an old and experienced one. The young wolves, after having passed two months in the den, where the father and mother nourish them, follow the latter, which is no longer able to satisfy a voracity daily becoming stronger. They help her in destroying animals, assisting in the hunt, and by degrees they succeed in aiding her to obtain the necessary food for their mutual support. The habitual exercise in plundering, under the eyes of an experienced mother, and having her example to follow, soon trains them.

They learn to remember those places frequented by game; their senses are alive to the slightest impressions; they accustom themselves to rectify by the sense of smelling the judgment which the other senses give them When they are eight or nine months old the she-wolf quits the preceding year's brood; she flees from or hunts her children, who ought not to need her any longer; and the young wolves find themselves abandoned to their 
own resources. The family remains united for some time, and this association is necessary to it; but the natural voracity of these animals soon separates them, because they cannot long bear the partition of the prey. The strongest remain masters of the ground; and those who are weaker go elsewhere to pass their life, or often to end it in hunger. The little experience which they yet have exposes them to all the perils which man prepares for them. It is then that they scour the country to look for the dead bodies of animals, because they have neither strength nor cleverness, as yet, to kill them. When they exist through this time of difficulty, their increased strength, and the instruction they have acquired, give them more skill in hunting. They are then able to attack large animals, of which one only will support them for several days. When they have slain one, they devour a part, and carefully hide the remains ; but this precaution does not keep them from the chase, and they only have recourse to what they have hidden when the hunt has been unproductive.

The wolf lives thus, in the excitement of the chase, during the night, and in an uneasy and light sleep during the day. This is its purely natural life; but in places where its wants are found opposed to man's wishes, the continual necessity of avoiding the traps set, and of providing for safety, constrain the wolf to extend the sphere of its activity to a much larger number of objects. Its walk, naturally free and bold, becomes precautionary and timid; its appetite is often suspended by fear; it distinguishes and recalls facts connected with its safety. 'Thus, at the same time that the wolf scents a flock enclosed in a park, the fear of the shepherd and his $\operatorname{dog}$ is recalled by memory, and balances the actual 
impression which he receives by the presence of sheep. He measures the height of the fold, compares it with his strength, judges of the difficulty of leaping it when loaded with his prey, and decides as to the uselessness or danger of the attempt. However, in the midst of a flock spread over the country, he will seize a sheep in sight of the shepherd, particularly if the neighbourhood of a wood leaves

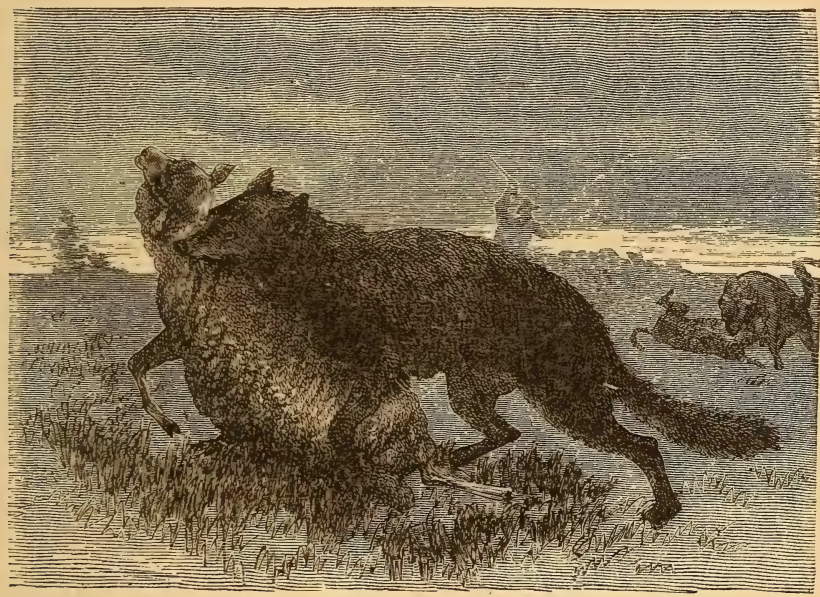

Wolves attacking a Flock.

him the hope of hiding himself before being caught. It is not necessary for an adult wolf to have much experience, when he is living in the neighbourhood of habitations, to learn that man is his enemy. As soon as man appears, the wolf is pursued; the riot and commotion show him how much he is hated, and all that he has to dread. Every time that the scent of man strikes his nose, it awakes in him thoughts of danger. The most seducing prey is presented 
to him uselessly, because it has an alarming suggestiveness, and even when it has it no longer, it leaves him suspicious for a long time. The wolf, then, can, at first, only have an abstract idea of danger, because he has not an intimate knowledge of the trap set for him. However, he entertains this idea, approaching a suspicious object by scarcely perceptible degrees; several nights hardly suffice to re-assure him. The scent of man suggests the notion of peril, and renders suspicious the most dainty baits.

It is a science of dread that the wolf is obliged to acquire; the interest in his preservation is never wanting in an adult wolf who has much experience, and extends more or less according to the circumstances which oblige him to think for himself and reflect. Without arguing like us, it is at least necessary that he should compare the feelings of danger he has experienced; that he should judge of the relations which objects have to each other, and those that they have with regard to him. Without this it would be impossible for him to foresee what he ought to fear or hope from objects. Naturally more rough than distrustful, experience renders the wolf watchful, and necessity makes him industrious. But he only has these qualities by acquisition, and they are never his natural powers. If he is hunted by dogs he only rids himself of the pursuit by his superior speed and power of lung. He never has recourse to doubling, and other schemes of weaker animals. The only precaution he takes, and indeed which he can take, is to always flee with his nose to the wind; this sense of smoll warns him faithfully of the dangerous objects which he may encounter on his road. $\mathrm{He}$ turns enough to avoid peril, but without losing the wind, which is always his guide. As he is vigorous and 
practised, and the chase has often forced him to run over a large extent of country, he directs his course towards the far-off places which he knows, and we cannot succeed in misleading him without multiplying ambuscades with much difficulty and preparation.

The wolf employs, when seeking his food, all his watchfulness and strength. He takes measures to assure himself of the place where he will find his prey. And if in this research he chooses one place rather than another, this choice arises from facts previously known. He thus observes for a long time the different kinds of peril to which he is exposed; and this calculation of probabilities holds him in suspense till appetite comes to put a weight in the balance and determines it. Precautions for safety require more foresight, that is to say, a greater number of facts engraved in the memory. The wolf must then compare all these facts with the sensations he feels, judge of the relation between these facts and the sensation, and at last come to a decision. All these operations are absolutely necessary. For example, it would be wrong to think that the fear which is excited by a sudden noise in the greater part of the carnivorous animals is a purely mechanical effect. The agitation of a leaf only excites in a young wolf a movement of curiosity; but the instructed wolf, who has seen the movement of a leaf announce a man, frightens himself with reason, because he judges of the relation between these two phenomena. When these have been often repeated, and the repetition has rendered habitual the actions which are the consequences of them, the promptitude with which the action follows the decision makes it appear mechanical. With a little reflection, it is impossible to misunderstand the steps which lead to it. 
It may be that the idea of this relation between the movement of a leaf and the presence of man is very lively, and realised on different occasions : then it will be established in the memory as a general idea. The wolf will find himself subject to idle fancies and false decisions, which are the fruit of imagination; and if these false opinions extend to a certain number of objects, he will become the plaything of illusions which will precipitate him into an infinity of false proceedings. He will see traps where there are none; fright, deranging his imagination, will represent to him, in another order, the different feelings which he has received, and will form out of them deceiving forms, to which he will attach an abstract idea of peril. This, in fact, is noticed in carnivorous animals everywhere, when they are often hunted and continually besieged with traps. Their proceedings have no longer the assurance and liberty of nature. The hunter, in following the animal's steps, only seeks to discover its lair. But the philosopher reads there the history of its thoughts; he unravels the uneasiness, frights, and hopes of the animal; he sees the motives which have rendered the steps precautionary, which have suspended or quickened them.

Associated wolves hunt together, and the help they give each other renders their chase easier and safer. If it is a question of attacking a flock, the she-wolf occupies herself with the dog, which she draws away after her, while the male leaps the fold and carries off a sheep. If they want to attack a wild beast, their work is divided according to strength. The he-wolf goes in search, attacks the animal, pursues it, and then the she-wolf attacks with fresh strength, and renders in a short time the combat very unequal.

It is easy to see how such actions result from intelli- 
ence, but it seems difficult to form associations of this ature without an articulate language. However, as has seen said, the wolf is one of those carnivorous animals which, considering its strength, has the least need of artifice. The necessity of rapine, the habit of murder, and the daily enjoyment of animals' limbs, torn and bleeding, do not appear as if they could form in the wolf a very interesting character. Yet, except in the case of rivalry, one does not see that wolves exercise direct cruelty against one another. As society exists between them, they defend each other mutually, and maternal tenderness is carried in the wolves to an excess of zeal which entirely despises peril. It is said that a wounded wolf is followed, and at last devoured by its fellows. But this is a rather disputed fact, which is surely not common, and may have sometimes been an effect of that necessity which knows no law. Every being leading a hard and isolated life, divided between solitary work and sleep, can be but slightly sensible to feelings of compassion. 


\section{THE FOX.}

THE fox has the same wants as the wolf, and the same inclination for plunder. $\mathrm{He}$ has senses as fine, more activity, and more suppleness; but he wants strength, and is constrained to supply the want by cleverness, tricks, and patience. One of the first effects of industry in which he is superior to the wolf, is that of making for himself a burrow, which shelters him from the coldness of the air, and serves him at the same time for a retreat. In order to spare himself trouble, he generally takes possession of those inhabited by rabbits, hunting them out and establishing himself. When some reason determines him on changing his locality, his first care is to visit all the burrows which may suit him, above all, those formerly inhabited by foxes. $\mathrm{He}$ examines them successively, and it is not till he has gone through them all that he fixes himself at last. But, if he is disturbed, even lightly, in that which he has chosen, he soon changes, and does not allow discomfort to approach the place which he has destined for his dwelling. The fox thus established, surveys in a short time all the environs of his burrow for a long distance. He takes notice of the villages, the hamlets, the isolated houses, and examines the poultry-yards; he informs himself of the places where the dog is loud and active, and of those where tranquillity reigns; he remembers the hedges and covered places which could favour his escape in case of peril. This train of pre- 
cautions, and so many possibilities foreseen, necessarily show that many facts are fixed in his memory. Always guided in his pace by a decided mistrust, he rarely lets himself be carried away in the heat of pursuit to follow a fiying prey; he gets near it, creeping along, and seizes it by jumping on it lightly. When he is well assured that tranquillity reigns in a poultry-yard, he tries to enter it, and his natural activity easily gives him the means. Then, if he is not disturbed, he profits by multiplying murders, till the approach of day makes him fear for his safety, and he retreats. He thus collects provisions for several days, and hides with care all the remains against a time of need.

If the fox is established in a country where there is much shooting, his industry has other forms to take to satisfy his voracity. Sometimes he runs about the country, with his nose to the wind, detects a hare in its dwelling, or some partridges lying down in a furrow. $\mathrm{He}$ approaches in silence; his steps, scarcely heard on the soft earth, show his lightness and the intention he has of surprising, and he often succeeds. Sometimes the fox succeeds by patience; he glides through the whole of the wood, observes a rabbit's run, hides himself, waits, and seizes the victim when it is unprepared.

But the hunt is not always immediately the object of the fox. Although satisfied with food, active foresight makes the animal again go out, less with the intention to seek for prey, than to acquaint itself more surely with the country which furnishes it with food. It often comes again on the same burrows it has before seen, goes the round of them with much precaution, enters, and carefully examines the different holes. The fox gradually approaches objects which are new to him: all novelty is suspicious, and each step in- 
dicates distrust and examination. However, the fox is often taken in snares, when these are not known to him; but as soon as they are noted, they become of no use. There is then no allurement which can make the fox brave the danger it recognises or suspects. It discovers the iron of the snare, and this sensation becomes terrible to it, and overcomes every other impression.

If the fox perceive that the snares are multiplied, it leaves its present home to find one more safe. Sometimes, emboldened by gradual and reiterated approaches, guided by the sure smell, it will find the means of quietly stealing a bait without exposing itself to the trap. One sees that this action supposes a keen sight and complicated combinations. We should never finish if we detailed all the causes which make the fox change its home, the motives which balance the power of habit, and all the varieties of its conduct. All this is necessary to a weak animal, which finds itself in competition with man, who opposes its wants and its pleasures. If it be a natural advantage to have a retreat, and a domicile, this is also one means more by which man attacks the fox. He easily discovers its dwelling, and then comes to take it; but man, with all his machines, wants much experience to overcome the prudence and cunning of the fox. If all the openings of the burrow are covered by snares, the animal discovers them, and sooner than be entrapped exposes itself to the most cruel hunger. We have known some remain nearly fifteen days in a hole, determined not to go out until hunger has left them no other choice than that of death. This fear which seizes the fox is neither mechanical nor inactive. There is no attempt it does not make to avoid peril ; as long as its claws remain it works at making a new 
opening, by which it often escapes from the snare of the hurter. If some rabbit has just been caught in one of the traps, the animal judges that the machine has done its work, and passes out boldly.

The only passion which makes the fox omit its ordinary precautions is affection for its family. The necessity of feeding the young renders the father and mother, but especially the former, more bold than they are for themselves, and this pressing interest makes them often brave peril. Hunters know how to profit by this love of the fox for the family. Common cares and interests engender affections which spread far beyond physical wants, properly so called. These animals, familiar with scenes of blood, do not hear, without being moved, the cries of their little suffering ones. Chickens certainly have the right of not looking upon them as compassionate animals; but their females, their children, and all of their species have not anything to complain of. This tender inquietude, which leads the female fox to forget herself, renders her keenly attentive to all dangers which might threaten the little ones. If a man comes near the burrow she carries them away during the following night; and she is often forced to turn out thus, because at these times the foxes arouse the neighbourhood by their ravages.

Besides the interest which man has in destroying the fox, he has made the hunting of this animal a means of amusement. At first the fox does not go very far from its retreat, but when alarmed by pursuit it goes far away, and to retard the progress of the dogs, passes into the thickets, which it well knows. If some hunters lie in wait to fire as it passes, it shuns them, and will attempt anything rather than pass near a man. 
We have seen one jump backwards and forwards three times over a wall nine feet high, to avoid the ambuscades prepared for it. But as the fox has only flight as a resource, and has less vigour than the dogs, after having exhausted all its power of flight, its dexterity and schemes, fatigue forces it to hide in some hole, where it often perishes.

It has been remarked that this animal's customary manner of living, and the details of its daily actions, lead us to expect deeper plans, more complicated schemes, and a wider and keener sight than the wolf has. Prudence is the resource of weakness, and it often guides the feeble better than boldness does strength. Montaigne shows how the inhabitants of Thrace, when they wish to pass over the ice of some frozen river, use the intelligence of the fox.

"They loosen a fox and send it before them. We saw the animal go to the river's bank, and put its ear close to the ice, as if to judge the thickness of the ice from the sound of the flowing water beneath. As it found by that means the ice to be more or less thick, so it went or drew back."

May we, then, not be right in judging that the same ideas pass through its head as through ours, and that it thus arranged an argument, and drew a conclusion: whatever makes a noise or moves is not frozen: whatever is not frozen is liquid; and whatever is liquid bends under the weight? To attribute that process to a lively sense of hearing only, without any reflection, may be a dream of our imagination. George Leroy adds that we remark in these animals an aptitude to teach themselves. They are ignorant and imbecile in places where open war is not made upon them, but become clever, penetrating, and cunning when 
fear of pain or death, presented under a thousand forms, has made them feel multiplied sensations.

These sensations are fixed in their memory; they produce judgments, which are not always sure, but experience rectifies them. It is easy to recognise in the

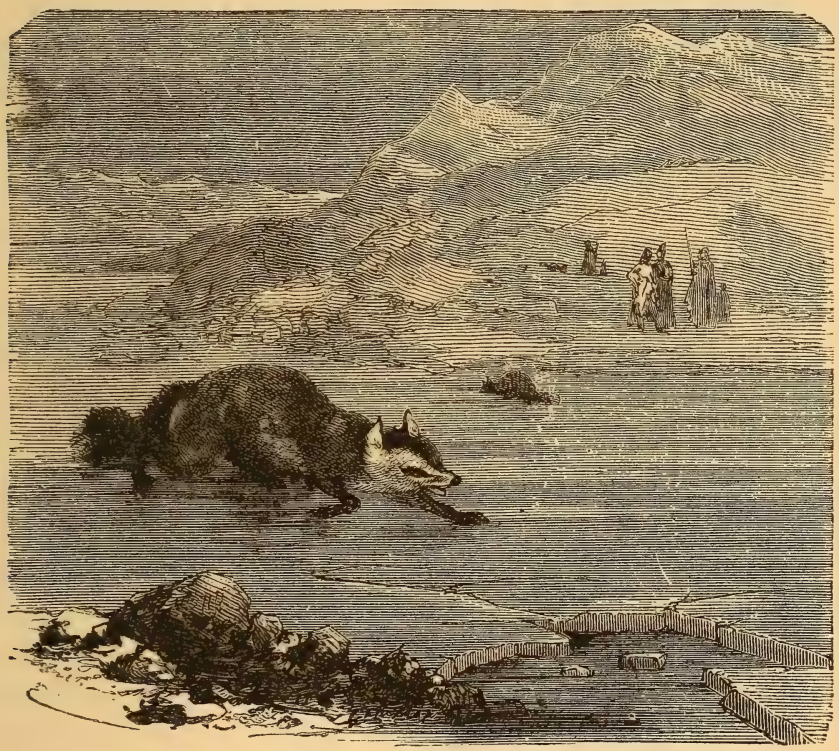

A Fox trying the Ice.

different ages of these animals their progress in the art of judging. In youth, imprudence and giddiness cause many false steps. Even the perils to which they are exposed often mislead their judgment, and make them look upon all unknown forms as dangerous.

Old wolves and foxes, which necessity has often put in 
the way of verifying their judgments, are less apt to be struck by false appearances, but are more cautious against real dangers. A misplaced fear may cause them to lose a night's work and a dinner. 'They have, therefore, a deep interest in acquiring habits of close observation. Their wants produce attention, and this power, once gained, enables the fox to separate the particulars which distinguish one object from another. The constant repetition of such acts renders the judgment of old foxes prompt, easy, and sure. 


\section{THE DOG.}

Do you know a more intelligent and devoted friend than the dog? When young you did what you liked with him; used him for a horse, rode on him, tied him to your barrow, you pulled his tail and his ears, and sometimes you varied your amusements by beating him.

He never complained; on the contrary, he seemed happy to receive even your maltreatments ; he cried a little, but he soon licked your hand, looked at you with the kindest eye, and even seemed to offer his back to have the honour of carrying you. Later, when you went to school, what was the last caress you received, the last cry you heard? It was that of your dog, which for a long time followed the carriage. And when you returned, without the least prize, who received you with the greatest joy, enthusiasm, and sincere friendship?-your dog. Poor beast! one would think he wished all the village to know you had arrived, he barked as loudly as he could, caressed your feet, ran to you in a frenzy of joy, and seemed to wish to send away all those who approached you.

Poor dog! He has been your protector and comforter, he is now your friend and companion, sharing your joys and pursuits. He accompanies you in the chase, and becomes, as it were, one with you. He is your guide, and you have only to follow his steps and least movements. It is he who teaches you to become skilful as a sportsman, 
seeming to say, "Seek, and you will find"-you only kill and profit by it. He does not ask to share the booty, but as a reward for his untiring zeal, weariness, and bleeding paws, craves only a morsel of bread and a little waterabove all, a kind look and a good word.

He begs no more, but, if you would make him very happy, let him lie on the carpet by your side, then he could not be happier. All night he dreams of the chase, gets up, fancies he is in pursuit, and seizes the prey, then barks in his sleep. But this is not all; this noble animal will do more; by his affection he becomes your confidant, your messenger of love; announces your arrival when you go to pay a visit. $\mathrm{He}$ can be gay to gain approbation, or grave, according to your will. He loves those whom you love, and in this respect will often be your best counsellor. You can judge by his manner of treating them who are friends and who are foes. But it is above all in time of trouble, when misfortune has shown you the hollowness of the world, that you can fully appreciate the tenderness, fidelity, and devotion of the dog. He will console and caress you, lick your hand, and regard you with a fond eye.

Everything in the disposition of a dog can be turned to account, because his nature is confiding and noble. Most dogs are ardent in their feelings, and full of sagacious activity. But if you would make use of this activity, you must first gain their hearts by kindness, and, we must say, by flattering them a little.

It is easy to understand that an animal, even with but little brain, being so wonderfully gifted with fine senses, might manifest much intelligence. The celebrated phrenologist, Gall, had a dog which possessed, he said, the organ 
of word-memory. " "On this subject I have made," says this phrenologist, "the following observations:-I have often spoken intentionally of things which might interest my dog, avoiding the mention of his name, and not letting any gesture escape me which would be likely to arouse his attention. $\mathrm{He}$ always exhibited pleasure or pain suitable to the occasion, and by his conduct afterwards showed that he understood perfectly well."

When Gall quitted Germany to establish himself at Paris, he brought his dog with him. At first the animal appeared astonished and unhappy, because he could not understand the conversation. However, by degrees, he learned some French, becoming equally clever in that as in German. "I assured myself of this," said Gall, "in sometimes speaking to him in French, and sometimes in German."

A person well known to Chaillot by the nick-name of "The Dog's Mother," has proved that the dog perfectly uriderstands much of the conversation carried on before him. M. Louis Noir relates that one day she made a decisive experiment in his presence. She pretended to be negociating the sale of her favourite spaniel; she argued the terms, without any peculiarity of manner, and without raising her voice. The dog began whining immediately, rolling at her feet, and entreating her, in dog-fashion, not to sell him. She gave twenty other conclusive proofs in a similar manner. In the same way that the dogs comprehended her language, she also understood theirs. She very truly remarked that a dog does not ask for water in the same manner that he begs for food. In fact, a dog is, perhaps, the best example one could take in order to prove that animals have a language of their own. It is evident that each species of animal possesses a language suitable to its 
instincts and manner of living. This language is composed of voice and gesture. The gesticulating language is much more extended amongst animals than that of the voice, especially in the superior orders. The dog best unites voice and gesture in the manifestation of its teelings. Observe the dog: some one knocks at the door, his voice is loud, threatening, and full of anger; his eye flashes, his tail is erect. Beware how you enter! An instant after the door opens-it is his master. The dog bounds forward, shows his delight by wagging his tail, looking up into his face, and uttering cries expressive of happiness. But observe him also when following his master's bier: his head bent downwards, his eyes fixed on the ground, his tail drooping, his step slow, his voice silent, and his whole attitude expressive of sorrow.

Each animal, then, has is language sufficient to express the emotions belonging to its nature, and to make them understood by animals of the same species, or, indeed, of any other. Those which do not possess the organ of voice make use of mimicry, rendering themselves well understood. The deficiency in one sense is compensated by the development of another. If animals had no language, how could they accomplish the education of their little ones? It has been remarked that, in countries where he fox is hunted by man, the young ones have more cunning than the old foxes in uninhabited countries. How can this be explained otherwise than that the young ones have received lessons from their parents?

The dog, as we have said, is one of the animals which can best express its feelings by voice and gesture. The more energetic the gesture, the greater intelligence and will are displayed. Feeble movement shows a careless disposi- 
tion; an energetic action, on the contrary, corresponds to a strong will, subduing even the instincts.

Everybody has seen an infuriated dog-the ears erect, stretched out, enlarged, and placed so as best to receive the impressions of sound. The outside of the ear, in dogs, is often directed to the same point as the eyes, when hunting. The organs of the inferior senses have expressions not less intelligible. See, says Gratiolet, how the nostrils dilate to receive pure and refreshing air. How they pucker up at the sides, elevate, and contract, in rejecting a bad smell. And with what delicacy they inhale sweet odours, which they wish to examine at leisure! And these movements are easy and free, if the odour be agreeable. If it be disagreeable, they are more irritable ; the nose then becomes more strongly curved; the upper lip rises lightly, swelling at its base. These motions show distrust, and a feeling of doubt about some food they are interested in, but with respect to which they are on their guard. The nose is with dogs the chief director of the whole body. The expression, the gestures, and the play of the physiognomy are clear signs of intelligence; and, if man alone has the power of laughing, the sporting-dog is said to have that of smiling.

It has often been asserted that the dog wants speech. If Leibnitz may be believed, even that faculty is not always wanting. This illustrious philosopher states that, in Saxony, he met with a dog which could pronounce twenty words quite distinctly.

Buffon could not refrain from acknowledging the intelligence of the dog. "For sagacity, attachment, and gratitude -in a word, for all the effects of instinct which resemble reason-the dog, amongst animals, is Nature's masterpiece. 
"The dog, faithful to man, will always maintain a certain degree of superiority, a power of dominion, so to speak, over the other animals. He commands and reigns supreme over the flock, where he makes himself better heard and understood than the shepherd. Safety, order, and discipline are the effects of his vigilance and activity in conducting creatures who submit to him, which he protects, and against which he never employs violence except to maintain peace. But it is especially in warfare, against hostile or independent flocks of animals, that his courage and intelligence are called forth and fully displayed. Natural talents are then united to acquired qualities. As soon as the sound of arms is heard, or the horn of the huntsman has given the signal for approaching conflict, burning with ardour, the dog manifests his joy by the most lively transports; he shows, by his gestures and cries of impatience, the desire to combat and vanquish. Then, moving forward silently, he reconnoitres the country, to discover and surprise the enemy in his stronghold. He tracks him out, follows him step by step, and, by different sounds, indicates the distance and species of the creature he is pursuing. In vain the enemy opposes cunning to sagacity, and employs all the resources of its instinct to make the pursuer lose the scent; in vain it tries to substitute another victim. The dog rarely misses the object of his pursuit, discovering by the scent all the windings of the labyrinth; and, after having triumphed over cunning, he succeeds at last in finding the object of the search.

"When education has brought this natural talent to perfection in the domesticated dog; when he has been taught to moderate his ardour, and regulate his movements; when he becomes accustomed to a kind discipline, necessary in 
the chase, he then hunts with skill, and almost always with success.

"The dog, independently of the beauty of his form, vivacity, strength, and lightness, possesses, in an eminent degree, all those qualities which are likely to attract the regard of man. A nature ardent and choleric-nay, even ferocious and sanguinary-renders the wild dog terrible to all the animals. This, in the domestic dog, gives place to the gentler dispositions, the pleasure of attaching itself, and the desire of pleasing. He comes, humbly, to lay at his master's feet his courage, strength, and talents; he awaits his commands to put them in force; consults, interrogates, and supplicates him. A look is sufficient: he comprehends wishes by signs. Without possessing, like man, the light of reason, the dog has warmth of feeling, fidelity, and constancy in his affections. $\mathrm{He}$ has neither ambition nor interested motives, and no fear but that of displeasing. He is all zeal, ardour, and obedience. More apt to remember benefits than outrages, he does not retaliate when badly treated; he submits, forgets, or only remembers in order to become more attached. Far from resenting or trying to escape from injury, he licks the hand which has given the blow, only uttering piteous cries, and finally, by his patience and submission, disarming our anger.

"More docile and more yielding than any other animal, not only can the dog be instructed in a short time, but he will even conform to the habits and manners of those around him-taking the tone, so to speak, of the house in which he lives. Like other domestics, he is lofty amongst great folks, and rustic when in the country; always zealous for his master, and knowing, by instinct, 
who are his friends. He pays no attention to indifferent people, and shows antipathy to those whom he considers intruders, knowing them by their clothes, voice, and gestures.

"While guarding the house at night, he becomes more fierce, sometimes even ferocious. He watches, and goes his rounds; scents strangers afar off, and, if they stop, or try to leap the fence, he rushes at them, and, by continual barking or growling, gives the alarm. As furious against men as against animals, he throws himself upon thieves, wounds and maims them, taking from them what they are about to carry off. Not content with having conquered, he reposes beside the recovered spoil, without touching it, even to satisfy his hunger; thus giving, at the same time, examples of courage, fidelity, and temperance.

"Let us suppose, for a moment, that the dog had not existed. How, then, could man have conquered, subdued, and brought into bondage the other animals? How could we, in the present day, discover, hunt, and destroy savage beasts? To insure our own safety, and render ourselves masters of the animal creation, we must commence by gaining over a party among the animals themselves, conciliating those capable of obedience and attachment by mildness and caresses, so as to form an opposing party to the others. The first effort of man has been, then, the education of the dog, the fruits of which are the conquest and peaceable possession of the earth."

To this comprehensive description we will add some very interesting observations by George Leroy. This animal, says he, is so well known, that his example alone would make us reject all idea of a merely mechanical action in beasts. How, indeed, could we attribute to an 
instinct destitute of reflection the various actions of this intelligent animal? It is not only useful to man, but, in subjection, preserves a rational liberty, exciting in his master tender emotions of interest and attachment, by a voluntary docility. According to the different methods in which we employ the dog, we can trace the progress of his intelligence in two different ways. One is due to the instruction he receives-that is to say, the habits we force him to adopt by the alternative of pain or pleasure. The other kind of progress must be ascribed to the animal's own experience, his reflections on the facts he remarks and the sensations he experiences.

The dog of the farm-yard, nearly always tied up, charged solely with the task of barking at strangers, remains in a state of feeble intelligence.

The sheep-dog, continually occupied in an office which calls forth the voice and teaching of his master, shows more spirit and discernment. All the facts relating to his work become established in his memory. This knowledge enables him to combine circumstances which guide him in details and modify his actions and movements.

If the flock pass near some corn, you see the vigilant guardian gather them together, and lead them away from the grain, which must be protected, keeping his eye on those who would trespass, overawing the rash by movements which terrify them, and chastising the obstinate, to which no warnings are of any avail. Do we not recognise reason as the origin of this variety of movements, made with so much discernment? If the dog had not learned to distinguish the grain from the ordinary pasture of the flock, how could he know that it was not to be eaten? Does he know that his motions must be adapted to the habits of the 
sheep? If unacquainted with these habits, then his conduct seems to be without motive.

But it is principally in the chase that we must follow this animal, to see the development of his intelligence. The chase is natural to the dog, which is a carnivorous animal. Thus man, in using it for this exercise, only modifies and turns to account an aptitude and taste which nature has bestowed upon the animal for its preservation. There are, then, in the actions of the dog, the combined results of education and nature; the former arising from strokes of the whip, the latter from his disposition; one or both of these two elements being more or less perceivable, according to the circumstances which afford the animal more or less activity.

Nature is displayed more freely in the hound than in other dogs. The habit of subjection makes him attentive to the movements of those who lead him, up to a certain point; but as he is not always under their hands, his own intelligence must act for itself; and the animal's experience often rectifies the judgment of the huntsman. The undivided attention the dogs give to the chase, the guidance of the animal which is let loose first to train them, and the chastisement they receive when they are on a wrong track, accustom them by degrees to distinguish by the scent the stag which is before them from all other creatures. But the deer, wearied by the pursuit, seeks to join his companions, and then a more exquisite discernment on the part of the dog becomes necessary. In this case nothing must be expected from the young ones. It belongs only to trained experience to exercise a prompt and sure judgment in this difficulty. It is only the old dogs which are undaunted, and pick out without hesitation the path their 
stag has taken through that of the other animals by which he is accompanied. Those which are yet inexperienced afford to the attentive huntsman a spectacle of uncertainty, and yet of activity, which merits observation. They are seen to waver and exhibit signs of hesitation. They place their noses to the ground most diligently, or else raise them to the branches, where the contact of the body of the animal in its passage would leave a stronger smell, and they are only at last determined by the voice of the huntsman, in whom they repose the same confidence that he himself has in the more experienced and practised dogs. If the hounds, for a moment carried away by ardour, overstep the track, and are about to lose it, the leaders of the pack take upon themselves to find it, by the only means men can employ. They go backwards and forwards, searching for the trace which has escaped them. The diligence of the huntsman could go no further, and in this case even the experienced dog seems often to be at his wits' end to find the means leading to success.

The setter has still more intimate and close relations with man. He hunts always under his eye, and nearly always under his hand. It is true happiness for this dog to take the game to his master. $\mathrm{He}$ is caressed if he does well, reproved and chastised if he does badly. His joy or grief breaks forth in either case, and there is established between man and dog an interchange of services, mutual gratitude, and attachment.

When the setter is young, but already rendered docile by strokes of the whip, he listens to the voice of his master only, and follows his orders with precision. But when he is older and more experienced, and guided in all he does by a sagacity more subtle and certain, he 
does not always show the same docility, althougn in general it may have become habitual with him. If, for example, the game is wounded, and the old and experienced dog is sure of finding the track, he does not allow himself to be turned from the pursuit by his master, who calls and threatens in vain. He knows he is serving him by his disobedience; and the caresses which follow success soon teach him that he ought in such cases to disobey. It is generally the custom with experienced sportsmen to lead the young dogs, and leave the old ones to do as they please. Every one can gain for himself experience with regard to this animal, which we can train at will, by the discipline of pleasure or pain; which attaches itself to man, and receives his lessons, but which, in cases where he feels his own experience will guide him more surely, opposes his will to that of his master, and resists unhesitatingly the power of habit and fear of blows.

It is more than probable that we owe a great part of the docility and subjection of the dog to a very long course of training, continued through many generations; at least, it is quite certain that some acquired qualities of animals are transmitted by birth. The habit of acting in certain ways modifies without doubt the organisation itself, and this, being perpetuated, becomes natural. There are few animals that cannot be tamed up to a certain point, by alternations of pleasure and pain. Those which Nature appears to have removed farthest from our influencewhich she has endowed with the surest instruments of liberty, such as birds of prey, submit to the yoke which want imposes on every being who feels it, and in a little time acquire a docility which is astonishing. We see them high in the air, obeying the call of the falconer, 
and allowing themseives to be guided by his movements, repeated experience having taught them that docility would surely conduct them to the prey. It is impossible to attribute to instinct alone-that is to say, to a blind and unreflecting impulse-those actions in animals in which their instinct is in a manner unnatural. We can assign no cause for some of their proceedings, unless by supposing them to have the power of reflecting on facts. The education of animals, without reflection, would be as incomprehensible as that of man without liberty. All education, however simple it may be, necessarily supposes the power of deliberating and choosing.

Adrian Leonard, author of a work on the education of animals, has studied the intelligence of dogs in connection with the formation of their skulls, and has divided them into the following classes:-

In the first class he places the dogs having large foreheads and projecting temples, showing a great development of brain. Such are spaniels, water-spaniels, hounds, terriers, and setters. All these dogs have drooping ears.

The second class comprises the mastiffs and harriers, gifted with less intelligence, and sense of smell less developed. Their foreheads are narrow, temples receding, noses long, and ears half pendant.

In the third class are the dogs with shortened noses, the skull rising little, and intelligence but feebly developed. Such are the different varieties of bull-dog and curs.

Leonard affirms, from his own experience, that the dogs whose intelligence is most easily developed are the setters, the eyes of which are most expressive, the movements quick, without violence, and the gait firm, with gracefulness. This author says that he has been able, by a certain 
method, to make the dogs do all that he wished, even when commanding the most opposite things. He would say to them, "Iie down," and then stopping them suddenly, command them to come to him, saying, "Be merry," then, an instant after, "Be sorrowful ;" putting a piece of bread before Brag, and saying, "This is for Dash;" then a second piece before Dash, with "This is for Brag;" then leaving the two pieces for some time before them, he would say, at length, "Eat it," and neither would mistake the piece placed before him for that intended for him. In these cases there was evidently an exercise of intelligence. The animals must necessarily have compared the different commands. For example, the dogs must have reasoned thus: "The piece placed before me is not intended for me, but that put before my companion. They tell me to eat; I must not mistake, lest I get punished." Evidently the animal has thought all this, and reasoning thus implies exercise of the intellectual faculties.

M. Emile de Tarade has become so thoroughly convinced of the intellectual aptitude of the dog, that he has just written a work on the means by which we can cultivate the intelligence of this animal. According to this author, a dog is not thoroughly instructed until he does everything that is told him, even in the absence of his master. Otherwise they are much in the same case as the dog Munito, who, notwithstanding his apparent cleverness, really knew nothing. "I followed his experiments," said M. Tarade, "until I discovered the solution of the enigma. Munito was placed in a circle, formed of large cards, on which were drawn letters or figures of various colours. Having a fine sense of hearing, he was quick in detecting the slight noise that his master (an Italian) made with his nail or toothpick, 
although the hand which gave the signal was concealed in the pocket. And the so-called learned dog walked round the circle, apparently reflecting, and stopped before the card desired by his master." Munito was frequently rewarded by receiving some bread and meat. M. Tarade calls this performance mere juggling. He protests against this manner of developing intelligence, which is, in fact, but the effect of obedience and subjection, and not a discipline of the intellectual faculties. $\mathrm{He}$ indicates a rapid and sure method of teaching a dog the use of words in their application to common objects. A dog, sufficiently exercised, ought to know letters, figures, colours, and furniture. He ought to be clear on the meaning of the prepositions-over, under, before, behind-and should be able to contrast!

The choice of a dog clearly depends on the use we desire to make of him. If you want a watch-dog, take a mastiff; you will find in him strength, courage, great attachment, and sufficient intelligence. A setter is best adapted for hunting on land; the spaniel for water-fowl. These two dogs are the most intelligent and most susceptible of education. The terrier, with its crooked legs, and pace thus deprived of fleetness, afford the rabbit some opportunities of resting, and is excellent for hunting this game. Coursing necessarily requires the employment of the greyhound, but there is not much to be done with him in the way of education, his intelligence being very limited. The formation of the brain, the lengthened skull, and receding form of the fore part of the head, may well be the cause, physiologically, of this inaptitude in the greyhound for a high course of education. This dog can only be employed with success in the chase to hunt the hare, espe- 
cially in level countries. These dogs have excellent sight, but their scent is, comparatively, very bad; so that the least thicket which hides the prey from sight makes them lose it immediately.

To the advice given by $\mathrm{M}$. Tarade respecting the choice of a dog for education, we will add the following passage, borrowed from Montaigne: "Sportsmen assure us that, in order to make choice of a puppy from amongst a number of others, it is better to leave the choice to the mother herself. In carrying them back to their bed, the first she takes up will always be the best. If we pretend to set fire to the bed on all sides, then the one she will try to rescue first. By this we learn that the mothers have a faculty of prognostication, which we do not possess, in respect to their little ones."

History abounds with facts attesting the intelligence and devotion of dogs. One author, speaking of them, says, "As to their friendship, it is much warmer and more constant than that of man." In confirmation of this opinion, he relates the story of "Hyrcanus," the dog of King Lysimachus. "His master having died, he persisted in remaining on his bed, neither eating nor drinking. The day having arrived for burning the body, the dog followed the corpse, and throwing himself into the fire, was burned. A dog belonging to one named Pyrrhus never moved from its master's bed when he lay dead, and allowed itself to be carried away with the corpse, and finally jumped into the funeral pile where the body of its master was burned."

Montaigne gives several other examples of the fidelity of dogs, amongst others that of a dog which guarded a temple at Athens. This animal having perceived a thief 
carrying off the finest of the jewels, barked loudly at him, but without being able to wake the keepers. Despairing of taking the thief, he foliowed him all night. At daybreak he went more slowly, but without losing sight of the robber, whose offered food was rejected. The dog made friends with the passers-by, and took food from their hands. If the thief stopped to rest, the dog remained near him. These facts having come to the ears of the temple-keepers, they went in search of the dog, asking what road they had taken. At length they found him and the thief at the town of Cromyon, whence the robber was conducted to Athens, where he was punished. The judges, as a reward to the dog, ordered him to be supplied with a certain allowance of food daily at the public expense, and recommended him to the care of the priests!

In 1803 a society was founded for the suppression of theft. A blocdhound was procured and trained to track out criminals. In order to test the utility of this new employment of the dog, a thief was let loose, about ten o'clock in the morning, from a place where there was a great concourse of people. An hour afterwards the dog was sent iri pursuit of the fugitive. At the end of the chase, which lasted an hour and a half, the bloodhound found the man, hidden ir. a tree, several miles from the place.

It is evident that it is by the keenness and certainty of his sight a dog is able to track a man or animal; but he does not the less exercise reflection and intelligence when, having discovered the object of his search, he begins to bark, and will not leave him.

A domestic, cischarged from the service of a gentleman, hid himself in the stables of his master during the night, 
and in revenge cut off the ears and tail of a favourite hunter. The dogs gave the alarm within an hour, and a bloodhound being introduced into the stables, immediately set out in pursuit. Having followed the track of the man for more than twenty miles, the animal stopped at the door of a house, whence it was impossible to entice him. Having succeeded in getting in, he went up-stairs, and pushing furiously against the door of the garret, he found the object of his search. The servant being in bed, the dog seized him immediately, and would have torn him to pieces, but, fortunately, the master had not lost sight of the movements of the animal, and hastened to the rescue.

After such remarkable facts, it is not astonishing that in some counties they have endeavoured to make use of the dog to aid the police in the towns and country by tracking criminals.

It has been objected that it is dangerous to entrust the dog with such functions, on account of the violence of his character; but the true English hound rarely bites those whom he pursues. He only tracks them to their hidingplaces, and then, by loud barkings, indicates the place where they are hidden.

These facts prove most clearly that dogs might be employed in the present day for the public protection of towns and villages.

Dr. Franklin relates the following very singular story of a dog, known by the name of "Peeler :"-

\section{THE POLICEMAN'S DOG.}

A few years ago, a policeman was killed at Kingstown, near Dublin, under very mysterious circumstances. A little, 
sharp, active dog, of the spaniel breed, would go in and out of the chamber where the body was lying each day, and seemed to take a personal interest in the inquest. The conduct of the dog occasioned some surprise, and one of the magistrates questioned the inspector to whom the dog belonged. "Oh!" replied the officer; "do you not know? I thought everybody knew Peeler, the policeman's dog." He then told the history of the dog, which is as follows:- Some years ago, poor little Peeler had tempted the appetite of an enormous dog of the Mount St. Bernard or Newfoundland breed, the giant-I may say the ogre-of his race. The unhappy spaniel ran great risk of being served up and devoured at the breakfast of his Canine Majesty, Gargantua of the Snows, when a policeman interfered, and, with a blow of his staff, laid low the strong and released the weak. From that moment Peeler entertained unlimited respect and gratitude towards policemen. Where they went he went, or, rather, followed them. He mounted guard with them, and relieved by his presence the weariness of a long beat, or, better still, aided his friends in arresting the disturbers of the public peace. Peeler constituted himself chief-inspector of police. $\mathrm{He}$ went from one station to another; and when he had visited one district of a town, continued his rounds to the other quarters. He has been seen to enter a first-class carriage on the Kingstown Railway, to go to Blackrock. There he visited the police-station; continued his tour of inspection; waited the arrival of the train, and went everywhere to observe the inhabitants. Having assured himself that all was in good order, he returned, by another train in the evening, to Kingstown.

But Peeler had also his antipathies as well as his attach- 
ments. There was one man especially for whom he manifested extreme rcpugnance. One day, meeting him in a railway carriage, he got out and waited for the following train, preferring to submit to half an hour's delay rather than subject himself to such companionship.

His partiality for policemen was extraordinary. Whenever he met a man in the uniform of a constable he expressed his joy by leaping and walking beside him. $\mathrm{He}$ even recognised and saluted them when dressed in plain clothes, but, of course, these were his old acquaintances. Thus sought after by this devoted animal, the guardians of the peace in the city of London did not treat him with less kindness and affection. Wherever Peeler appeared, he received a crust of bread, a friendly tap on the head or stroke on the back.

As Peeler loved policemen during their lives, he did not forget them when they were dead. Finally, we find him assisting at the funeral of Daly, the policeman who was killed at Kingstown.

\section{THE SHOEBLACK'S DOG.-OTHER EXAMPLES.}

People when they go out in the streets like to appear clean and neat, and especially are careful to have their boots nicely polished. An Englishman was crossing one of the bridges over the Seine, in Paris, when he was met by a poodle-dog, which, rubbing its muddy paws over his dainty boots, completely effaced their brilliant polish. Seeing a shoeblack stationed on the bridge, he went to have the nutrage repaired. The same misadventure happening to him the next day, and on several others in succession, the curiosity of the Englishman was excited, and he observed 
the dog attentively. He saw him go towards the Seine, dip his paws in the mud by the side of the river, then go on to the bridge to await the arrival of any well-dressed ferson upon whose boots he might rub his paws. Discovering that the dog belonged to the shoeblack, the geniisman questioned the latter very closely. After some

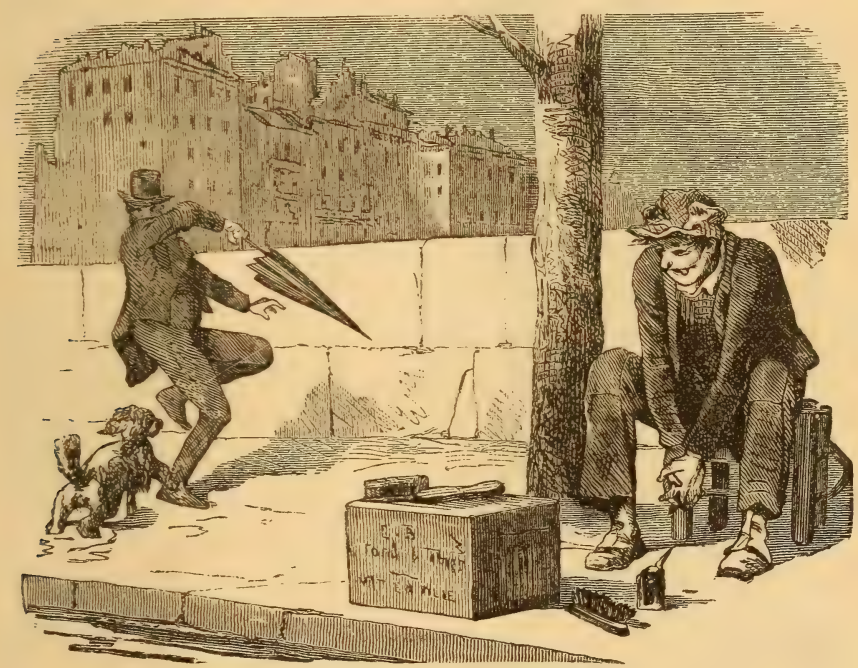

The Shoeblack's Doz.

moments of hesitation, the man owned that he had trained his dog to this exercise in order to procure customers. "Ah, Monsieur," added he, "trade is so bad!" The gentleman, struck with the sagacity of the dog, bought him, and brought him to London. The new master having kept the animal tied up for some time, at length allowed him to run loose; the dog only stayed with him a day or two, 
and then made his escape. A fortnight after he was found with his first master, pursuing his old occupation on one of the bridges of Paris !

Tulian Scaliger and the "History of Montargis" have handed down to us the

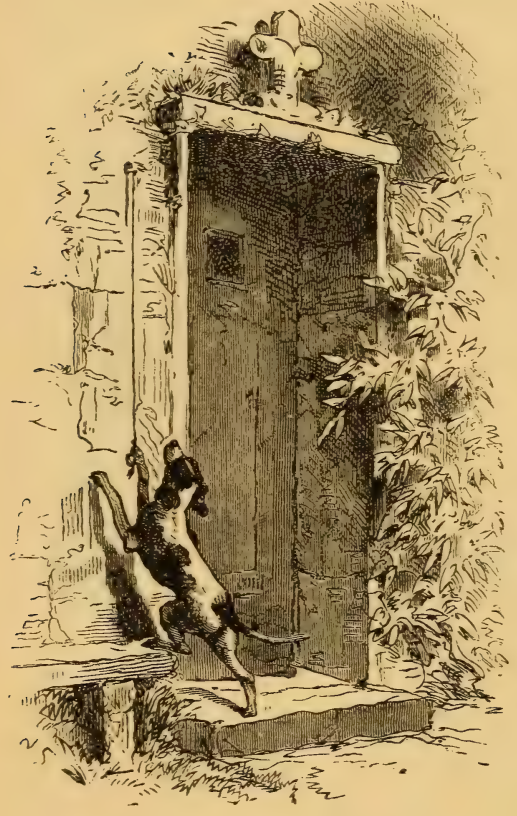

The Dog at the Convent Door. touching story of the dog of Aubrey de Montdidier. This story, the events of which occurred in the time of Charles V., is so well known, that we deem it unnecessary to repeat it here.

"In r66o," says Sonnini, "all Paris might have seen a dog which remained for several years near the tomb of its master in the Cemetery of the Innocents, and from which nothing could remove it. Several times they carried it away to the extremity of the city, and shut the creature up; but as soon as it was let loose it returned to the post of its constant affection, notwithstanding the severity of the winter. The inhabitants of the neighbourhood, touched by its constancy and perseverance, used to carry it some food; but the poor animal seemed only to eat enough 
o prolong his sufferings, and afford an example of heroic :delity."

At the time of the Revolution, when many scenes of slood were being witnessed at Brotteaux, a dog followed his master who was condemned to be shot. After the execution the dog laid himself upon the corpse, obstinately refusing to be separated from it; and, rejecting all nourishment, died some days after.

Everybody knows the story of the French dog which, having seen beggars ring the bell at the door of the convent and receive some soup, began to ring also, in order to receive a ration.

We will give another proof of canine sagacity and gratitude. A surgeon found a dog with its paw broken; he carried the animal home, reduced the fracture, and set him at liberty. Some months after, he was not a little astonished to see the animal he had succoured enter his house, accompanied by another dog, which had also a fractured paw !

\section{THE NEWFOUNDLAND DOG.}

Everybody has heard of the intelligence and devotion of the Alpine spaniels, which, on the lofty mountains of the Alps, go in search of travellers overtaken by the snow.

The monks of Mount St. Bernard, the hospitable inhabitants of those icy and nearly inaccessible mountains, do not fail to send every day, during the winter, a servant, accompanied by two dogs, to meet the travellers from the side of Valais, as far as St. Pierre. The dogs follow the track of the traveller who has lost his way; they find him, bring him to the monastery, and rescue him from inevitable death. 
We will relate an anecdote of a Newfoundland dog, borrowed from the Bulletin of the Society for the Protection of Animals :- "An individual, whom, from regard to his honour, we forbear to name, had an old Newfoundland dog, which, for economy's sake, he wished to get rid of, to save the dog tax. This man, with a view of executing his cruel design, led his old servant to the banks of the Seine, tied his paws together with string, and rolled him off the barge into the current. The dog, in struggling, contrived to break his bonds, and managed, with great difficulty, to climb the steep bank of the river, where he arrived almost breathless. Here his unworthy master awaited him with a stick. $\mathrm{He}$ repulsed the animal, and struck at him violently; but, in the effort, lost his balance and fell into the river. He would have been drowned most assuredly, had not his dog been more humane than himself. But the animal, faithful to the natural mission of his race, and forgetting in a moment the treatment he had just received, jumped into the water, from which he had only just escaped, to rescue his would-be executioner from death. He did not accomplish this task without much difficulty; and both returned home-the one meekly rejoicing at having accomplished his good deed and obtained favour, the other disarmed and, let us hope, repentant."

\section{THE NEWFOUNDLAND DOG AND THE MASTIFF.}

We have yet another anecdote, proving the excellence of disposition in the Newfoundland dog. A dog of this race and a mastiff detested each other. Every day produced fresh battles between them. But it happened that, in one of these terrible and prolonged combats on the jetty 
of Donaghadee, they both fell into the sea. The jetty was long and steep; they had no other means of escape but that of swimming, and the distance was considerable. The Newfoundland, being a good swimmer, managed to reach the shore without much difficulty. He landed dripping wet, and began shaking himself. A moment after, he saw that his late antagonist was exhausting himself in struggling against the waves, and was just on the point of sinking. The Newfoundland was moved with a feeling of generosity: he flung himself again into the water, seized the mastiff by the collar, and holding his head above the water, brought him safe and sound to land. This happy deliverance was followed by a scene between these two animals that was truly touching. They never fought again, and were always seen together. The Newfoundland, being at last crushed beneath a wagon loaded with stones, the other dog was for a long time inconsolable.

\section{VAILLANT.}

In his work on the education of the dog, M. de Tarade relates an incident recently told by $\mathrm{M}$. Léonce Guine. Two children, of the ages of twelve and fifteen-the age with little pity-came to a part of the Seine, level with the Rue de la Grande-Arche, to drown a poor and blind dog, half dead with hunger and old age. He had become useless as a servant, and they were about to dismiss him in the usual manner-they would drown him, to spare him the sufferings of desertion and hunger! What could be more reasonable? Is it not thus that domestic animals are generally treated when they become good for nothing ? It was with malicious pleasure and cruel joy that these 
children had thrown the poor animal into the midst of the waves. Not content with this, the little murderers pelted their victim with a shower of stones. His piteous howlings and cries of despair, far from moving their compassion, only excited their cruel mirth. By low moaning at inter-

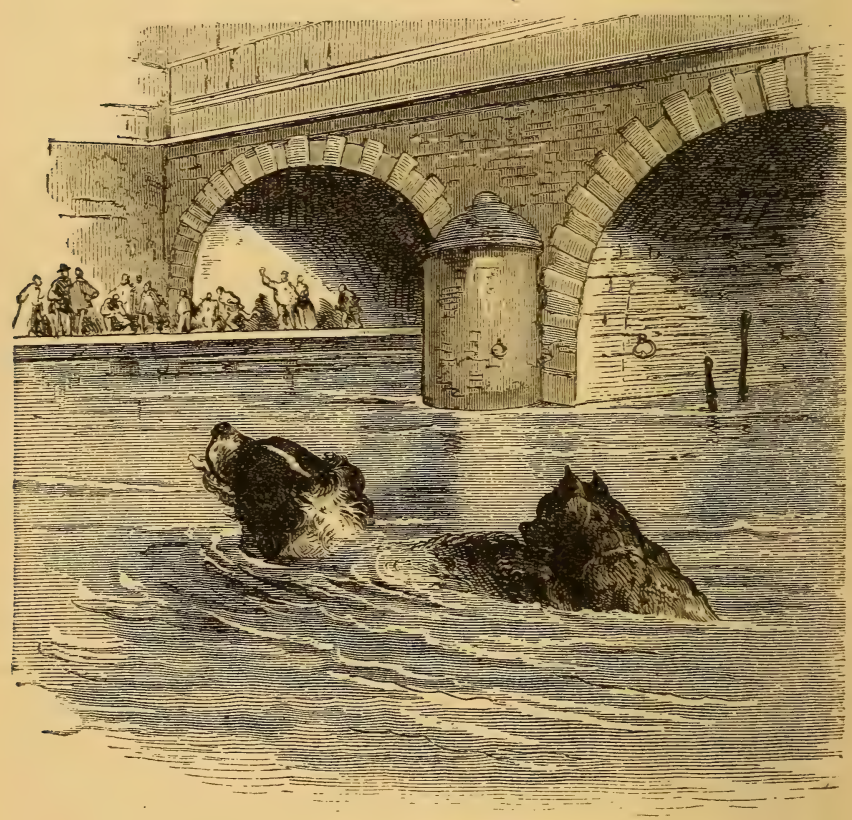

Vaillant rescuing the Blind Dog.

vals, they learned, to their great satisfaction, that the noor dog was wounded by their missiles. "I was about to close my window," says M. Guine, "so as to shut out this painful sight-amusing, no doubt, to the idle and worthless, though much opposed to the usually humane characier of the 
Parisians - when suddenly I heard loud shouts and great clapping of hands from the mob who were diverting themselves with this brutal spectacle. I looked, and perceived with some surprise my dog Vaillant, who, attracted by the mournful cries of one of his own species, had jumped into the river, and was swimming towards him. He went through the water with incredible activity. His joyful cries, and the direction he was taking, at once convinced me of the animal's intentions-Vaillant was hastening to the rescue!

"The poor blind dog, guessing that unexpected help was at hand, seemed to renew his efforts for life. A few more struggles brought him to Vaillant. The latter, well knowing the danger of the task he had undertaken, raised his hind-quarters in such a manner that the poor drowning beast could cling securely with his front paws, without interfering too much with his own movements. He then began to swim vigorously towards the shore. His efforts were crowned with success. In a few minutes he was on terra firma, proudly shaking his fine coat, while his companion fell exhansted at his side. My dog's devotion, however, did not stop there. The children, who had not reckoned upon this unexpected rescue, and who still wished to indulge themselves with the spectacle of a drowning dog, tried to drive him away with a stick, but, in approaching him, they were so terrified by the sight of his flashing eyes and the two rows of formidable white teeth which he displayed in his fury, that they were forced to renounce their intention, and retrace their steps. This action on the part of Vaillant did not surprise me much, because he is an affectionate animal, as well as very intelligent; but the spectators, who did not know him so well as I, loaded hin with so many 
caresses, that I feared he would adopt the same means to get rid of their importunities that he had taker. to drive away the two boys. I therefore put an end to the general enthusiasm, and preserved the calves of the most eager from the marks of his teeth, by calling Vaillant to me. For the first time, I may say, the docile animal refused to obey my call. I soon comprehended his motive: he was not willing to leave his protégé to the mercy of his enemies. At my request, one of the mob took the poor blind dog on his shoulder, it being still too weak to drag itself along, and carried it to my dog's bed. It was only on this condition that the latter could be induced to steal away from the ovation of the crowd, in order to pay to his guest the honours of the kennel."

\section{BRILLANT.}

Another hero of the canine race has for some time, so L'Indépendance Belge relates, ceased to fulfil any of the functions usually assigned to dogs by their masters. Brillant has risen in rank; he has cleared, at one bound, the distance between the kennel and the office; from being simply the guardian of the night, he has become messenger, factotum, confidential servant. With a little arithmetic and literature, he might become an accountant, perhaps secretary. Every morning Master Brillant, with head raised, and his basket suspended jauntily between his teeth, makes his first visit to the baker, who, on account of his good conduct and discretion, does not hesitate to give him his master's bread. Various other errands wait his return; and the zealous "commissionaire," always provided with his basket, goes successively, and simply by a verbal indication, to the grocer, the fruiterer, and the public-house, whence he 
brings a bottle filled which he had taken empty. A little later in the day he is the courier of his master; and it is most amusing and interesting to see him, with one or two letters in his mouth, standing on his hind legs, just below the letter-box of the General Post-office, one of his paws supporting him against the wall, the other pulling the dress of a passer-by or the postman to attract their attention, and then, by gestures, begging them to put the letters into the box, the opening of which he is not able to reach. And all these feats of memory, discernment, and reasoning, so to speak, are accomplished by this intelligent animal with perfect order and punctuality, without being led or directed, except by signs, and without making any mistake in the different commissions with which he is entrusted.

\section{MOFFINO.}

Everybody at Milan knows the history, for it is not simply a story, of the spaniel Moffino. This dog followed his master, who belonged to the corps of Prince Eugène Beauharnais, on the occasion of the disastrous expedition into Russia in r8r 2. At the passage of the Beresina these two faithful companions were separated by the masses of ice which floated down the river, and the Milanese corporal returned to his native city full of sorrow and regret, not on account of his wounds, but for the loss of his poor dog, which had shared with him so much misery and suffering. A year passed by, and the soldier, in the midst of his family, had almost forgotten the object of his regret. One day, however, the people of the house were surprised by the arrival of the spectre of an animal that might formerly have been a dog, but which now scarcely deserved the 
name. It was something truly hideous that they tried to drive away without pity, notwithstanding the mournful cries of the poor beast. At this moment the ex-corporal returned from a walk, and saw advancing toivards him, with joyful bounds, this wretched quadruped, which licked his feet, uttering at the same time low whinings. He repulsed it

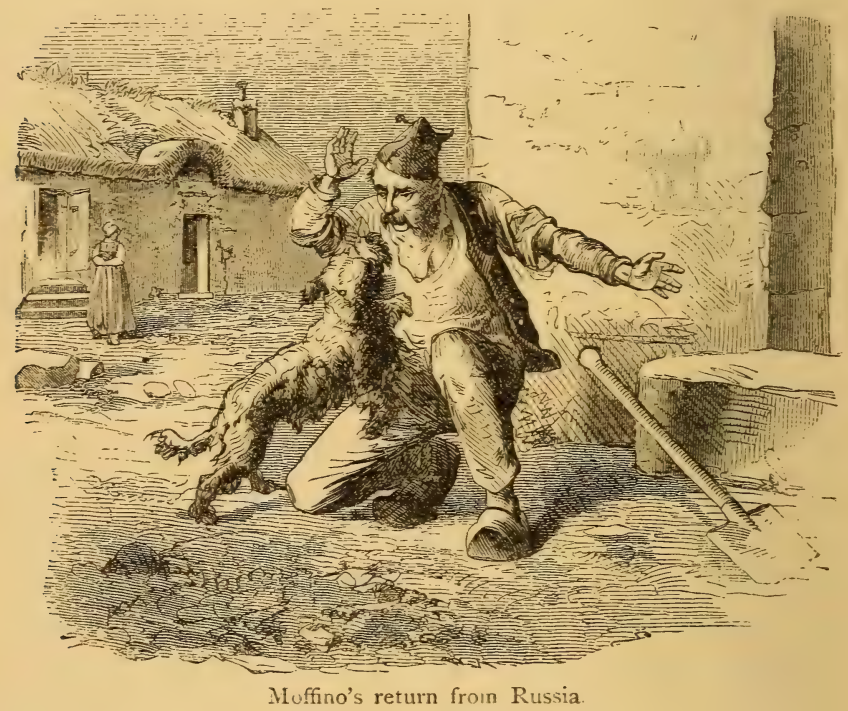

roughly, and was about to deprive this singular visitor of the little life that appeared to be remaining, when a sudden thought occurring to him, he examined certain marks on it with attention, indications of which caused him much joy. He pronounced the name " Moffino," and the animal jumped up immediately, barking joyfully, and then fell down, exhausted with hunger, fatigue-perhaps, one might say, with 
emotion. His master, who now recognised his lost dog, hastened to his assistance, succoured him tenderly, and saved him from death.

This journey over more than the half of Europe, undertaken by an animal without any guide but his wonderful instinct, the mountains and rivers crossed by this feeble creature in search of his master, at the price of terrible sufferings, is a great lesson for the generality of mankind.

THE FISHING-DOG, OR THE SPANIEL OF THE "CORDELIERS D'ÉTAMPES."

We find, in the "History d'Etampes," the feats and doings, not of a learned dog like Munito, of whom we have already spoken-one applauded for useless talents-but of a spaniel as useful as clever, and which, during several years, was the purveyor of the "Pères Cordeliers." * His dexterity in fishing for crabs deserves to be recorded. It has been the subject of a Latin poem, composed, in I7 I4, by Claude Charles Hémard de Danjouan, a young inhabitant of d'Étampes. Many a capital dinner did the fishing-dos provide for the friars, to whom he brought, not only crabs, but various fish, captured with no small trouble, and great dexterity.

\section{THE DOGS OF BOISVILLE-LA-ST. FÈRE.}

We shall end these remarks on the dog by the story of two sporting-dogs, which may claim a place in our work. This narrative was told by M. Baumer, a locksmith of

* A branch of the Grey Friars, so called from their girdle made of cords. 
Angerville. One fine morning, the butcher of Boisville-laSt. Père, wishing to have a feast, said to his wife, "I am going to kill a rabbit." He set out, according to his usual custom, with his two dogs-male and female. These animals were almost mad with joy; they jumped, frisked, barked, ran forward, and then back again to their master.

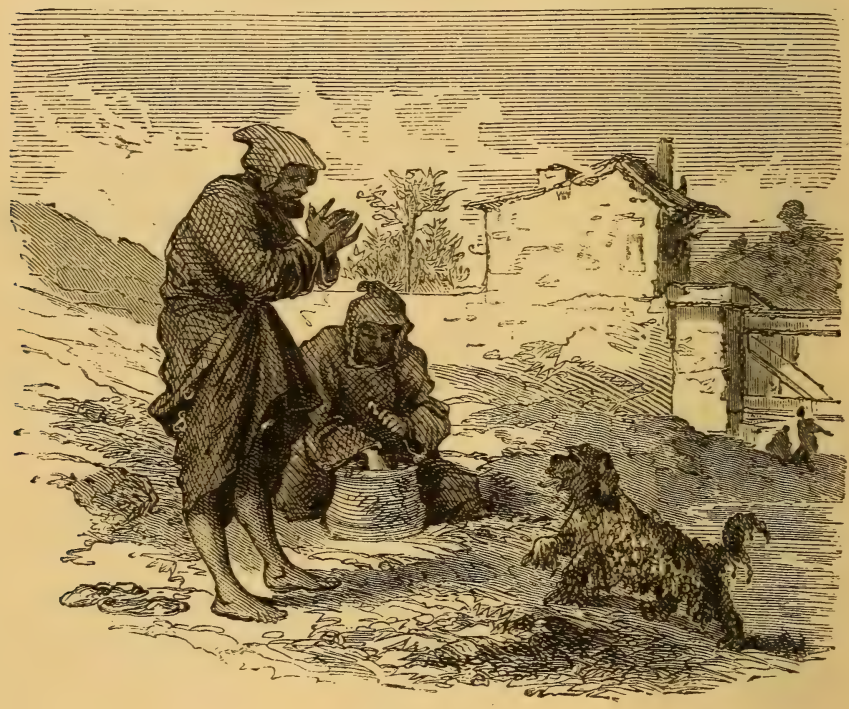

The Fishing-dog.

Threats and kicks could not subdue their ardour, nor quiet their tumult. The sportsman went towards a wood situated near the village. Having arrived there, the poor butcher, for some reason not explained, mounted a tree, and, in order to climb more easily, took his gun-strap between his teeth. He had scarcely reached the lower branches, when, one of them touching the trigger, the gun went off, and the 
imprudent hunter, receiving all the contents, fell bathed in blood. His poor dogs then began to howl most piteously. Only a few distant woodmen heard their cries; night was coming on-what could they do? Go away-abandon their master? A servant might have done so; a dog, never! The two faithful creatures remained all night, without thinking one instant of eating or drinking. The morning found them still there, barking every now and then as if calling for help. As no one came, one of them returned to the village, while the other stayed by their master. He arrived at the house, and reassured every one by his presence. "When the dog arrives," said they, "the master is not far behind." They gave the poor animal some food, but, notwithstanding his long fast, he ate but little, looked at everybody wistfully, and then disappeared. They went out to see which direction it had taken. Just then the other dog arrived; they caressed her, and gave her also something to eat. As soon as she had finished she went to one of the workmen in the house, looked at him wistfully, and pulling him by his blouse, seemed to say, "Follow me." Accordingly, they set out with her, which seemed to give her much satisfaction. She advanced eagerly, stopping from time to time to see if they were still following. As she approached the wood she slackened her pace, frequently looked behind her, and at last, on arriving, the poor animal walked gently and silently up to its master. The other dog was lying upon him, awaiting anxiously the return of its companion. Both began to lick their master's face, trying to awake him, and warn him that some one was near. The officers of justice being informed of the sad accident, went to the place indicat $\mathrm{d}$, recorded the death, and took away the corpse in a 
carriage, the dogs following. Arrived at the house, they would not leave the body, but remained lying near it, howling mournfully. With much trouble, the people dragged them away into a barn; but, far from being quiet, they uttered cries which were heart-rending. The unfortunate man being interred, the dogs were set at liberty. The cemetery of Boisville, like those of most villages, was not difficult of access. Our two poor dogs, by scent, soon discovered the grave of their master. They scratched a long time, and at last succeeded in finding the coffin, on which they were found lying the next morning. The villagers dragged them back to the barn, petted, caressed, gave them food, and used every means to console them; but nothing succeeded. They began howling again, refused all nourishment, and, three days afterwards, died of grief. What can exceed this touching proof of genuine affection and attachment? 


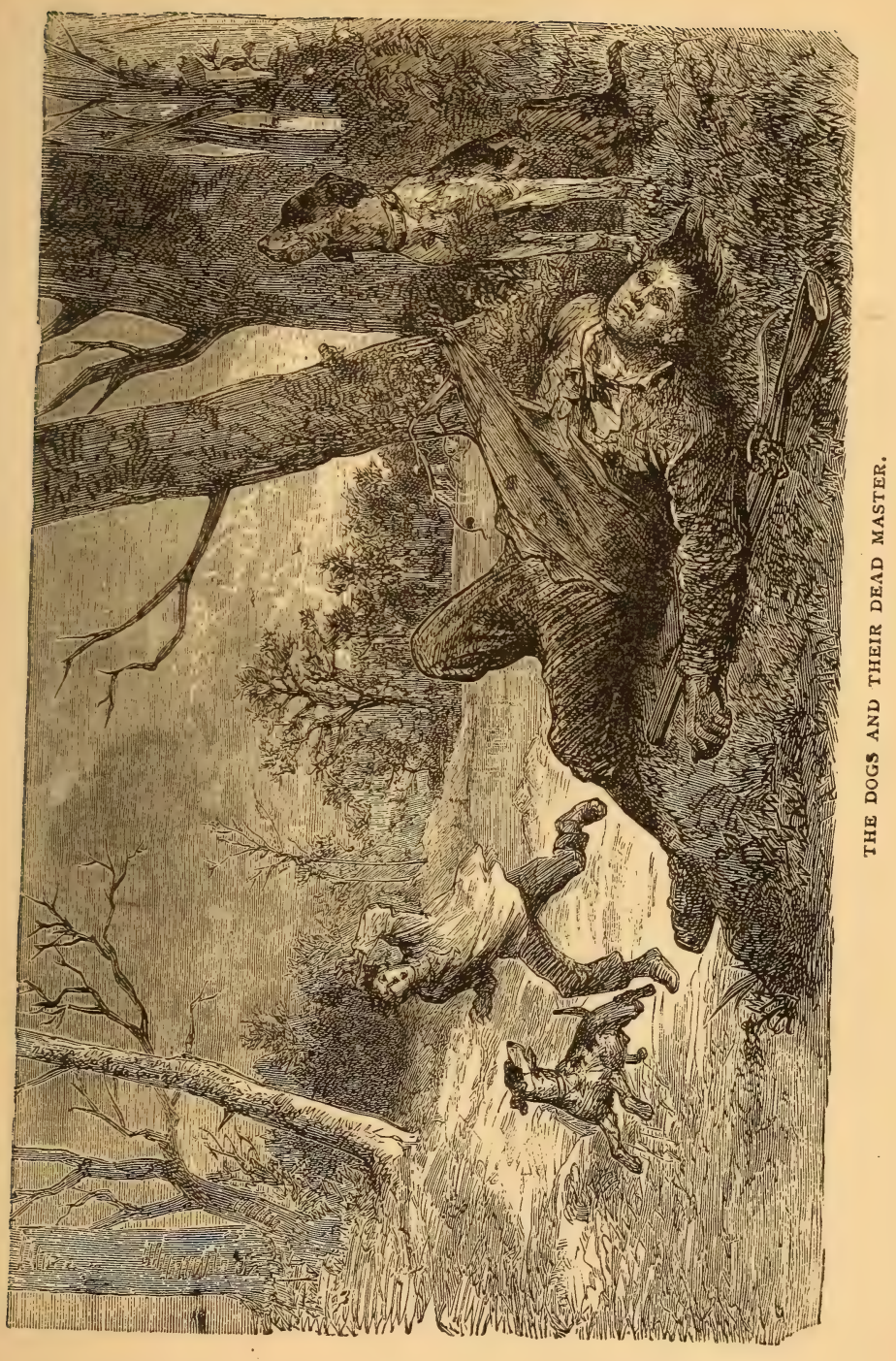





\section{QUADRUMANA.*}

MONKEYS, ORANG-OUTANGS, CHIMPANZEES

The Quadrumana, the feet of which are really formed like hands, are the creatures most closely resembling man. These animals, which Linnæus calls "primates," to show their superiority over all others, are distinguished by the following characteristic resemblance to man:-Their teats are generally on the breast, and two in number; the four thumbs are generally opposable to the other fingers, the thumbs of the hind feet being always so ; the brain, which is almost always provided with circumvolutions, has, like that of man, the olfactory lobes smaller than those of other animals.

The Quadrumana consist of three principal families, the monkeys, the lemurs, and the apes.

The monkeys, so various in species, so remarkable for the vivacity of their manners, and for the resemblance they bear to the human race, are spread over the Old Continent as well as the New, but their characteristics differ in each of these great portions of the globe.

Bearing a greater resemblance to man than those of America, the monkeys of the old world have thirty-two teeth, disposed in the same order as in the human jaw.

* A word signifying four-handed. 
They have the partition which separates the narrow nostrils. The tail is not always endued with the power of grasping, being sometimes short, or even not visible at all. In this case they have, under the skin, a rudimentary bone, süci as exists also in man.*

The apes that approach nearest to man are the orangoutang of Borneo, the chimpanzee, the gorilla end koolookamba of Western Africa, and the long-armed ape of the Indian continent and adjacent isles.

- This bone is called the os coccȳgle 


\section{THE ORANG-OUTANG.}

THE ORANG-OUTANG AS A DOMESTIC.-EATING AT TABLE.COUNTERFEITING AN OLD MAN, A PREACHER.-UNFASTENING HIS CHAIN, AND CARRYING IT ON HIS SHOULDERS.

THE orang-outang has a less facial angle* than the chimpanzee. This is the reason why most naturalists consider it as less intelligent than the latter. The orang-outang is commonly called "the wild man of the woods." It is of a reddish colour, more or less dark, and sometimes becomes very dark with age; its hair is long, but not thick; the lower and fore parts of the body are almost bare, as well as the ears and the face, which is black; the head is covered with rather long hair. These creatures inhabit the Isles of Borneo, Sumatra, the Malay peninsula, and live in the depths of the forests. The orang-outang had been considered for some time as quite distinct from the pongo, but is now known to be the same animal, at two different periods of its life. The pongo is an adult of the orang species, of which young ones only have hitherto been brought to Europe. +

In its wild state the orang-outang is alert, endowed with great strength, constantly clinging to the trees, in the midst

* The slope of a line drawn from the chin to the forehead is called the facial angle.

+ It must not be forgotten that the name pongo has also been given both to the gorilla and the chimpanzee. 
of which it runs and leaps with extreme agility. On the ground the orang-outangs are grave and quiet, and have not that capricious or brutal petulance which characterises some quadrumana. The young have always shown much intelligence, gentleness of disposition, and remarkable sociability. They grow weary of solitude, but, nevertheless, do not like too many visitors.

"These animals," says Frédéric Cuvier, "acquire without difficulty all the actions to which their organisation is not opposed. This results from their confidence, docility, and their great facility or comprehension. After the first attempt they understand what is required of them ; that is to say, having performed the action shown them, they know they must repeat it themselves in the same manner. Thus they drink from a glass, eat with a fork or spoon, make use of a dinner-napkin, wait at table behind their master's chair like a servant, and, it is said, can assist him to wine."

Frédéric Cuvier gives the account or an orang-outang which, in order to make its escape from a cage, mounted a chair and unfastened the door. He concludes, with reason, that these actions are the result of a superior intelligence and combination of ideas.

Buffon tells us that he has seen this animal give its hand to the people who visited it, to show them out, walking gravely with them as one of themselves. "I have seen it," he adds, "sit down to table, unfold its dinner-napkin to wipe its mouth, make use of a spoon and fork in feeding itself, pour out its drink, jingle glasses when invited to do so, take a cup and saucer, bring them to table, putting in sugar, then pouring out the tea, leave it to get cold before drinking; and all this without any other direction than a sign or word from its master, and often entirely of its own accord." 
It never hurts any one, always approaches them cautiously, and presents itself as if asking to be caressed.

The orang-outang seen by M. Flourens in the Zoological Gardens did all these things. It was very gentle, extremely fond of being caressed, particularly by children, played with them, and tried to imitate all their actions. He knew perfectly well where to find the key belonging to the room in which he was lodged, how to put it into the lock and open the door. Sometimes they put the key on the chimneypiece. The orang-outang climbed to it, by means of a rope attached to the board, which served him for a swing. They tied a knot in the cord to make it shorter, which knot he managed to undo. He had no: the impatience or petulance of the monkeys. His apprarance was sorrowful, and his movements grave and measured. "One day," says M. Flourens, "I paid him a visit, accompanied by an illustrious old gentleman, who was a clever, shrewd observer. His somewhat peculiar costume, bent body, and slow, feeble walk at once attracted the attention of the young animal, who, while doing most complacently all that was required of him, kept his eyes fixed on the object of his curiosity. We were about leaving, when he approached his new visitor, and, with mingled gentleness and mischief, took the stick which he carried, and pretending to lean upon it, rounding his shoulders, and slackening his pace, walked round the room, imitating the figure and gait of my old friend. He then gave him back the stick of his own accord, and we took our leave, convinced that he also knew how to observe."

The orang-outang has been sometimes tamed in eastern countries, where the temperature suits its nature and habits. M. Coubasson had brought up a young ape of this family. 
The animal was so attached to the missionary, that wherever he went it seemed desirous of following him. Every time the "father" had some religious service to perform, he was obliged to shut up the orang-outang in a room. One day, however, the animal made his escape, and followed his master into the church. There he quietly mounted to the top of the organ above the pulpit, where he remained until the sermon commenced. Then he slipped down slily to the front, and looking steadfastly at the preacher, began imitating his gestures in so droll a manner, that all the congregation were seized with an irresistible desire to laugh. The father, surprised and confounded at this levity, severely reprimanded his inattentive audience. The rebuke was ineffectual. The congregation still appearing diverted, the preacher, in the warmth of his zeal, redoubled his efforts to engage their attention. The monkey imitated so cleverly the vehemence of this oratorical action, that the congregation could no longer restrain their mirth, but burst out into continual peals of laughter. The father, now thoroughly vexed and angry, threatened his hearers with the wrath of heaven. At length a friend indicated with his finger the cause of this unseemly mirth, and the preacher began to laugh himself. The attendants then with some difficulty removed the ape which had thus abused his powers of imitation.

Dr. Abel has written a curious account of the manners and habits of the orang-outang. We will quote only that part which relates to the intelligence of this animal. "The orang-outang," says he, "since his arrival at Java, has enjoyed full and perfect liberty, which he does not abuse, and makes no attempt whatever to escape. A day or two only before his departure for England, in the Casar, they judged 
it prudent to put him in a cage, secured with bars of bamboo. This imprisonment made him furious. When he was placed in captivity he took hold of the bars, and shaking them violently, tried to break them in pieces; but finding that the firmness of the fence would not yield to his efforts, he reflected that it would be better to try another wayby attacking each bar separately. Having discovered that one bar was not so strong as the others, he worked at it without ceasing until he had broken it, and then made his escape. On board the vessel they tried to confine him by means of a chain attached to a strong pole, but he managed to release himself, and ran oft, dragging the chain after him. Finding that the length of this chain incommoded him, he rolled it up and threw it over his shoulder. $\mathrm{He}$ often repeated this manouvre, and when he found that the chain would not lie as he wished, he took it in his mouth. In the means he adopted to procure his food, he gave us still more reason to appreciate his talents and sagacity. He seemed very desirous of obtaining the tit-bits, kept out of his reach, showed great anger when they were withheld from him, and would pursue any one all round the vessel to obtain something nice. I rarely came on deck without some sweetmeats or fruit in my pocket, and in such case never escaped his vigilant eye. I sometimes tried to escape from him by mounting to the top of the mast, but was always anticipated in my flight. When climbing the shrouds with me, he always made sure of his position by placing one of his hands on my legs. During this time the rogue would try to pick my pockets. If he found it impossible to surprise me in this way, he would climb to a considerable height on the ropes, and then jump suddenly upon me; but if, guessing his inten- 
tion, I tried to descend, he would slide down the rope and meet me at the bottom of the shrouds. Sometimes I tied an orange to the end of a string, and let it down from the top of the mast on to the deck. Each time he attempted to seize it I drew it slowly towards me. Having been several times foiled in his attempts, he changed his tactics. Pretending not to care about having the orange, he retired to some distance, and, with well-feigned indifference, began to mount the rigging; then, by means of a sudden leap, he seized the string which held the fruit. If it happened that he was again disappointed in his design by the quickness of my movements, he gave himself up to despair, abandoned the attempt, and climbed into the rigging, uttering piercing cries. $\mathrm{He}$ was seen more than once at the door of his keeper's cabin sipping his coffee, nowise embarrassed by the presence of observers, and affecting a serio-comic air, which seemed like a caricature of human nature.

"The monkeys which we had brought from Java gained but little of his attention when he was observed by persons on board; but I had reason to suspect that he was not so indifferent to their society as he wished one to believe. I saw him one day on the mizenmast, playing stealthily with one of these young monkeys. Lying on his back, partly concealed by the sail, he regarded with much gravity the gambols of the little creature which frolicked around him. At last he caught it by the tail, and began wrapping it up in his covering. This mode of subjection was not in accordance with the taste of our mischievous little fellow, who made his escape, and recommenced his gambols. Although caught several times, it always managed to get away. The intercourse between orang-outang and monkey is not always 
that of equality ; for the former never condescended to play with this little creature as he did with the cabin-boys of the vessel. Several times these monkeys were seen in ambuscade, or creeping furtively round him, without his responding to their advances. Such are the facts," adds Dr. Abel, " of which we were witnesses during an intercourse of several months with this animal. I have written from my own observation during the voyage from Java to England. Since the ape's arrival in Great Britain he has acquired, to my knowledge, two accomplishments which he had not learned on board ship, where, I must own, his education was much neglected. One is to walk upright, at least, on his hind feet, without supporting himself with his hands; the second is to kiss his keeper." Some writers affirm that the orang-outang gives real kisses, and they suppose that it is a natural action of the animal. This seems to be a mistake ; it is an acquired act. Certain naturalists have denied the superiority of intelligence in the orang-outang over that of the domestic dog. They draw certain inferences from the anatomy of the ape, saying, for example, that the cerebral mass of the brain of the orang-outang is not in accordance with the actions of the animal. Dr. Franklin remarks, with reason, that the orang-outang is a wild animal, or nearly so, taken suddenly from his native climate, habits, forest life, and natural element. In a state of captivity its faculties, far from acquiring a high degree of development, must often become feeble. But the orang-outang, without being instructed by man, does accomplish acts of which the most sagacious and best instructed of our dogs is incapable. If the dog is chained up, and the chain becomes entangled, the animal pulls it forcibly towards him, and often increases the evil, instead of removing it. If the obstacle continues, he 
becomes frightened, and cries out, but never thinks of searching into the cause of the mischance. It is not so with the orang-outang; the moment a similar accident happens to him, he tries to find out the real state of things. You will not see him pulling against a powerful obstacle with blind force; he stops at once, as a man would do in similar circumstances. He turns round to examine the cause of the occurrence. If the chain be entangled by a heap or weight of any kind, he disengages it. In every case he seeks the why and wherefore. Is not this seeking for causes a manifest sign of intelligence? Another proof of the sagacity of these apes is the facility with which they recognise the pictures of insects or birds placed before them. It is true they mistake them for the reality, and try to take hold of them, and crush them, or else flee away if they have any cause to fear the animals depicted. In the same manner, when they see themselves in a looking-glass, they make signs, then go behind to look for the animal which is making grimaces in return for their own. Savages would not act more consistently. These intellectual manifestations are only seen in the species occupying the first rank in the order; the inferior kinds are more stupid, perhaps, than the least intelligent of the carnivora.

The Courrier d'Orient relates a fact which proves at once the degree of intelligent development to which some monkeys can attain. Three or four children, aged about seven or eight, were amusing themselves on the Place Sultan Mehemmed looking at monkeys dancing to the sound of the tambour, and they especially admired one of these animals, which played this instrument very cleverly, at the same time acting as guide to a poor blind man, his master, whom he conducted with an address and foresight equal to any man. 
This interesting animal made, from time to time, the round for begging money, presenting with one hand the blind man to the spectators, with the other the tambour to receive the alms. Pieces of money and fruits were freely bestowed, and the monkey hastened to put all into the wallet of his master.

The children had been the first to put their offerings into the tambour, and in each case they were small pieces of money, destined, no doubt, for the purchase of sweetmeats, but, being well-disposed children, they preferred giving their money in charity. Suddenly the youngest of the children uttered a cry, at the same time putting his hand to his head. A thief had snatched at his cap, ornamented with pearls and set round with gold. Not being able to snatch it off, thanks to the strap which fastened it under the chin, he contented himself with tearing off one of the gold ornaments. The thief was immediately arrested. Can you guess by whom? By the monkey, who recognised him in the crowd, and pointed him out by fastening on to his clothes with his teeth and claws. Everybody hastened to his assistance, but he never left his hold until the arrival of an officer, who carried off the criminal to the station. The monkey, quite proud of his exploit, hastened to kiss the hand of the child he had so courageously protected; then, having received this favour as his only recompense, he continued his performances 1 


\section{THE CHIMPANZEE.}

Most naturalists agree that of all known apes the chimpanzee approaches nearest to man, not only by the volume of the brain, but in the whole of its organisation. The formation of the head, ${ }^{*}$ the intellectual superiority which distinguishes the features, the length of the arms-in better proportion to the size of the body than those of other apes-the size and perfect formation of the thumb, the roundness of the thighs, the almost human form of the feet, and consequently the nearly upright mode of walking, and the nature of the sounds which the animal is capable of making, all place the chimpanzee above the other Quadrumana, and bring it near to man.

Linnæus, in the first edition of his "System of Nature," speaks of a "genus homo," under the denomination of "homo silvestris" or troglodyte. $t$ Since then, a distinct genus has been found-the genus troglodyte of zoologists -and the species the best known bears the name of troglodyte niger, or black chimpanzee. This animal has the forehead rounded, but concealed by the arched eyebrows, the size of which is extreme. The face is brown and bare, with the exception of the cheeks, on which are

* The cranium of the kooloo-kamba, as figured by Du Challlu, is superior in form to that of the chimpanzee.

+ A Greek word, denoting a dweller in caves. 
some hairs like whiskers. The eyes are small, but full of expression; the nose flat, and the mouth large.

The chimpanzee attains to the height of five or six feet, and, when supported by leaning on a stick, can walk upright for several minutes. The hair is thicker on the back, shoulders, and legs than on other parts of the body, and is generally black.

The chimpanzee is a native of Africa, and is only to be found in the forests of Congo and Guinea. When young, it is remarkable for gentleness and the ease with which it is tamed; but loses, as it grows older, most of these good qualities, which are succeeded by very ferocious instincts. It does not then hesitate to attack man; and, armed with a

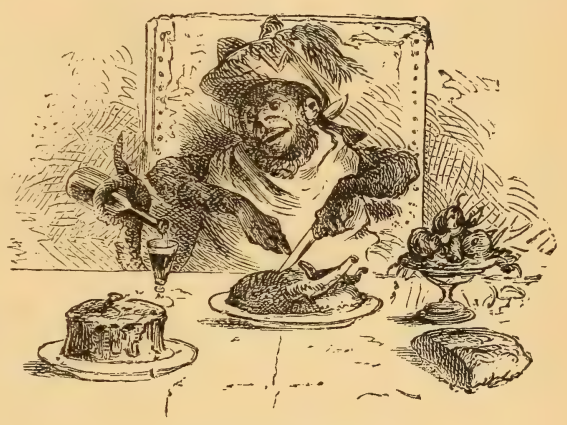

Chimpanzee at Table. stick, it strikes with violence. But the young chimpanzees are capable of being instructed in various ways. They learn to sit at table like civilised man; partake of everything, particularly sweetmeats; and can even become habituated to strong spirits. They can use a knife, fork, and spoon in eating; will receive their visitors with much politeness, stay to bear them company, and show them out!

The chimpanzee is a native of the tropical parts of Africa; while the orang-outang is found in Asia. Its life in a wild state is little known, except from the accounts 
given by the natives of the country. It is, they say, a formidable adversary for the elephant, as well as the carnivorous animals, which it assails by blows from sticks or stones.

One of the signs of superiority in man is the power of making use of extraneous aid, and adding this to his own strength. In this respect the chimpanzee holds a kind of intermediate position between man and the other animals. Its tactics, however limited they may be, show gleams of reason; they are, in fact, the rudiments of human strategy, the first step towards dominion.

From certain comparative studies of the chimpanzee and orang-outang, it is generally acknowledged that the former has superior sociable habits, and a better recollection of the persons usually about him. He sits perfectly upright at table, and takes up food with the greatest ease between his thumb and forefinger. The chimpanzee loves bright colours, and is especially attentive to a female wearing a gay dress! He delights to look out of windows; the carriages and horses passing by seem to astonish him, and afford him much pleasure. The chimpanzee is more gentle in appearance, more graceful in form, and more civilised in manners than the orang-outang; and there exists the same difference in the faculties of these two animals as in their exterior characteristics.

Captain Payne has thus described the habits of a chimpanzee which had been obtained by a merchantman on the coast of the river Gambia, and which he was commissioned to bring to London in 1831 . "When the animal came on board," says he, "he gave several fingers of his hand to some of the sailors, but refused this mark of confidence, even angrily, to others, without any apparent reason. $\mathrm{He}$ 
soon, however, became familiar with all the crew, with the exception of one young cabin-boy, with whom he would never make friends. When the sailors were taking their meals on deck he was always at hand, making the round of the table, embracing each guest, uttering cries, and then seating himself amongst them to partake of the food. He sometimes expressed anger by a kind of bark, resembling that of a dog; at other times he would cry like a peevish child, and scratch himself violently. When they gave him something nice, especially sweetmeats, he expressed his satisfaction by a sound resembling "Hem!" uttered in a grave tone. Beyond these, the variety of sounds in his language did not appear very extensive. In hot latitudes he was lively and active; but languor took possession of him when we quitted the torrid zone. In approaching our shores, he manifested a desire to wrap himself up in warm coverings. He generally walked on all-fours; never, however, placing the palms of his fore-feet on the ground, but, closing his hands, supported himself on the joints of his fingers. He rarely used the upright posture, although he could run quickly, for a short distance, on his hind feet. He learned easily to eat with a spoon and drink from a glass. When in our society he showed a great inclination to imitate the actions of men. The lustre of metals and shining bodies attracted him. He was not insensible to coquetry, and exhibited a kind of vanity in clothing himself with the garments of human beings. $\mathrm{He}$ was seen several times walking proudly on deck with a cocked hat on his head."

The Museum of Natural History at Paris, thirty years ago, possessed a chimpanzee which showed much intelligence. One day, when it had been put in confinement for some fault, it experienced a desire common to all living 
beings when shut up, that is to say, a wish to recover liberty; only it showed in this enterprise a perception of consequences, and a method of surmounting difficulties, which were very remarkable. It first of all fixed its eyes on the door of the room in which it was imprisoned; but this door was locked, and the key hung on a nail. The ape was not discouraged by this obstacle. Raising himself on the points of his toes, he tried to possess himself of the key, but the nail hung too high for him to reach it. After several useless attempts, in which the animal showed as much perseverance as sagacity, it comprehended that the key was placed at such a distance that it would never be able to reach it even with the tips of his fingers. It then placed a chair against the wall, mounted, and unhooked the key. That done, it got down, inserted it very clevesly into the lock, and unfastened the door.

"Who, after this, will dare gainsay

That beasts have sense as well as they?

For me-could I the ruler be-

They should have just as much as we,

In youth, at least. In early years,

Who thinks, reflects, or ever fears ?

Or if we do-unmeaning elves-

'Tis scarcely known e'en to ourselves.

Thus, by examples clear and plain,

We for these poor creatures claim

Sense to think, reflect, and plan,

And in their actions rival man :

Their guide-not instinct blind alone,

But reason, somewhat like our own !n 

.

. 



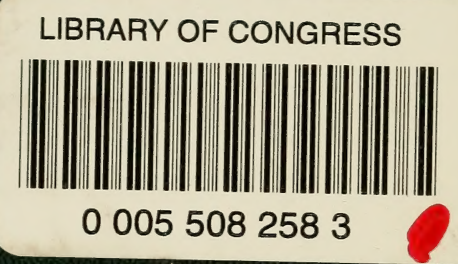

